\title{
ASIA-PACIFIC REPORT Focus: China in the Reform Era
}

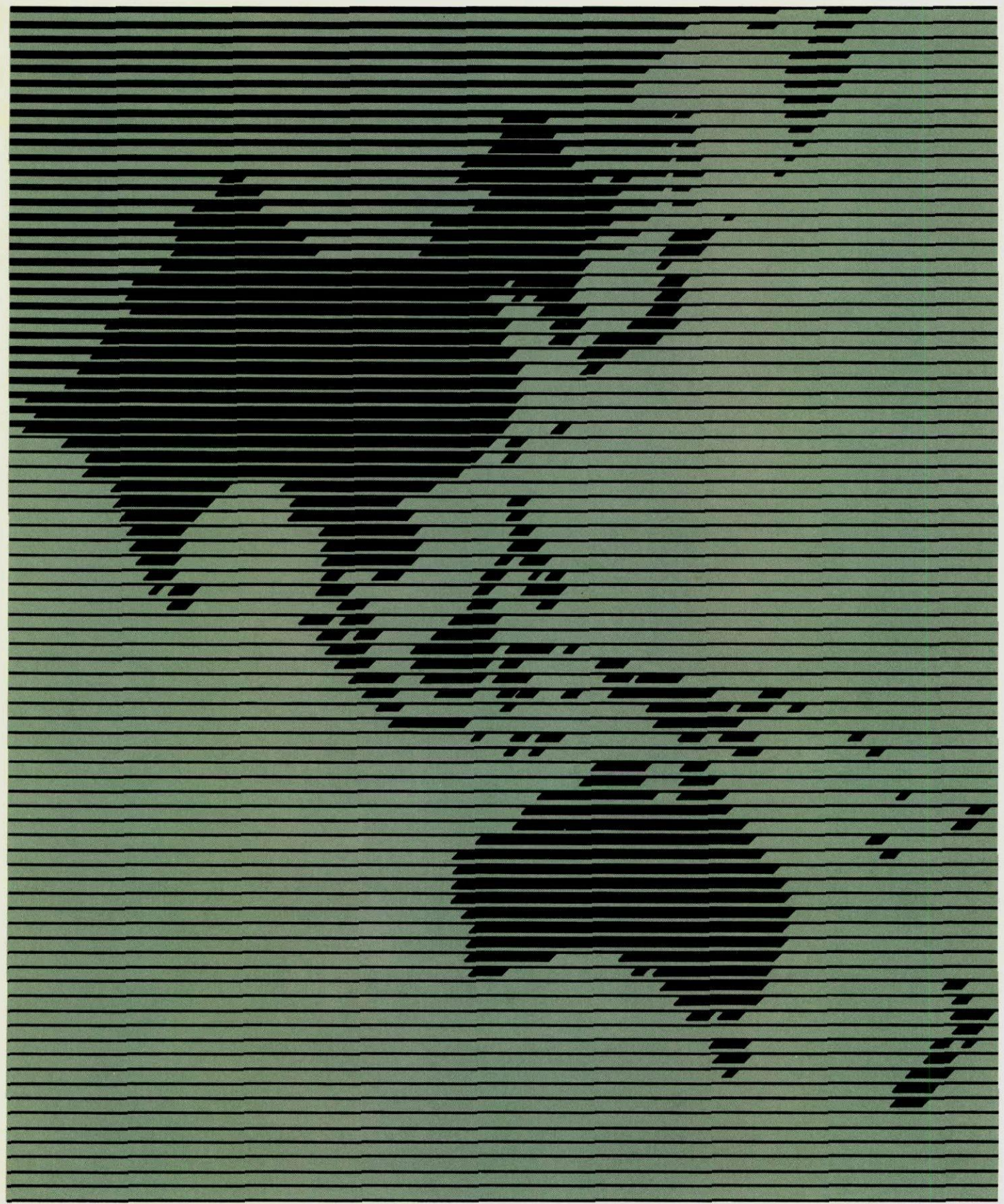

玉 East-West Center • 1989 


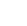




\section{ASIA-PACIFIC R E P O R T}

1989

Focus:

China in the Reform Era

Edited by

Charles E. Morrison

and

Robert F. Dernberger 
(C) 1989 by the East-West Center

All rights reserved. Published in 1989 by the East-West Center, 1777 East-West Road, Honolulu, Hawaii

Printed in the United States of America

9089

321

Library of Congress Cataloging in Publication Data

Asia-Pacific report.

1. Asia-Economic conditions-19452. Pacific Area-Economic conditions. 3. Asia-Politics and government. 4. Pacific Area-Politics and government. 5. AsiaForeign relations. 6. Pacific Area-Foreign relations.

I. Morrison, Charles Edward, 1944- . II. Dernberger, Robert F., 1929- . III. East-West Center.

HC412.A72415 $1989 \quad 909^{\prime} .098230828 \quad 89-1103$

ISBN 0-86638-111-2 


\section{CONTENTS}

Foreword

Part I The Asia-Pacific Region:

The Political and Economic Context

Chapter 1 Politics and International Relations:

The Winds of Change

Chapter 2 The Asia-Pacific Economy:

Structural Change and Renewed

Growth

Part II Special Report:

China in the Reform Era

Chapter 3 The People's Republic of China:

A Historical Introduction

Chapter 4 China's Political Reforms

Chapter 5 China's Economic Reforms

Chapter 6 Demographic and Social Change in China

Chapter 7 Problems and Prospects for China's Mineral and Energy Industries

Chapter 8 Environmental Problems and

Economic Modernization

Chapter 9 Evolutionary Changes in Chinese

Culture

Chapter 10 China's Role in the Asia-Pacific

Region 


\section{MAPS}

The Asia-Pacific Region

I.1 Significant Domestic Political Events in 1988 China

8.1 Important Physical Features of Eastern China

\section{BOXES}

1.1 Asian Women Political Leaders

1.2 Cautious Political Change in Vietnam

1.3 India's Role in the Subcominent's Security

2.1 The Growth of Intra-Asian Trade

3.1 China in the 20th Century

5.1 China's Open-Door Policy

7.1 China's Transportation Problems

8.1 China's Environmental Protection Organizations

8.2 Water Use in Beijing and Tianjin

9.1 The Fifth Generation Chinese Filmmakers

10.1 China's Growing Maritime Power

\section{BOX FIGURES}

2.1 Intraregional Trade among Developing Countries: 1975-87

7.I China's Transportation Usage

\section{FIGURES}

1.1 1988 Parliamentary Results

5.1 Changes in the Structure of China's Economy

5.2 China's Per Capita Consumption of Key' Commodities

6.1 Crude Birth and Death Rates in China: 1950-87

6.2 Projection of Dependent Populations in China: 1970-2050

\section{TEXT TABLES}

5.1 Invesiment and Consumption in China: 1952-87

5.2 Foreign Trade and Investment

6.1 Fertility Rates and Total Population for Selected Years

7.1 China's Mineral and Energy Trade: 1987

54

60

66

76

\section{APPENDIX TABLES}

\section{Demographics}

1. Population Indicators

2. Aging and Health Indicators

Economics

3. Average Annual Real Growth Rates and Nominal Levels of GDP and Per Capita GDP

4. Average Annual Inflation Rates

5. Structure of GDP

6. Investment and Domestic Saving Ratios

7. Trade Shares of GDP

8. Merchandise Imports from Selected Asia-Pacific Trading Partners and Total Imports

9. Merchandise Exports to Selected Asia-Pacific Trading Parıners and Total Exports

10. Average Annual Capital Inflows by Type

II. Average Annual Disbursements of Net Financial Inflows from OECD and OPEC Economies by Flow Type

\section{Communications}

12. Communications Media in the Region

Defense

13. Asia-Pacific Defense Statistics 


\section{FOREWORD}

$\mathbf{T}$ Report. This report series is intended to provide an This report series is intended to provide an overview and analysis of major political and economic developments and issues that challenge policymakers in the region and more in-depth studies of special topics of regional significance.

A great deal has happened in the region since our first report in 1986. For example, extensive political transformation is occurring, which can be illustrated by the change in senior leadership. In our first report, we included a list of nine senior leaders. By the time of our 1987-88 report, seven continued in office. Since only four of our original list-in China, Indonesia, North Korea, and Singapore-now remain, we have dropped this list. As pointed out in chapter 1, much of the political change has been in the direction of more participatory political processes. The new democratic governments in the Philippines, South Korea, and Pakistan and the political liberalization of a number of other Asia-Pacific countries suggest a broad regional trend toward participatory government. Yet this trend, as encouraging as it is, comes in the face of long traditions of paternalistic authority. This is a time of testing these new political forms. The new democracies face a major challenge in showing that they can provide effective government.

During the past three years, the region has demonstrated its flexibility in meeting economic challenges. The appreciation of the yen and other Northeast Asian currencies and the low prices of many commodities produced in Southeast Asia threatened the Asia-Pacific region's reputation for dynamic economic growth. Yet the policymakers and private sectors proved their adaptability. The year 1988 was one of strong growth in Japan, the newly industrialized economies, China and Thailand, of economic recovery in other Southeast Asian countries, and continued progress in South Asia.
This report marks a new departure for the AsiaPacific Report. For the first time, we have commissioned a series of chapters around a single theme, inviting contributions from distinguished specialists outside the Center as well as Center staff and current participants.

It seemed appropriate that China, the region's most populous society, should be the subject of our first series of studies. The authors of the eight chapters on China provide a portrait of a country engaged in a serious economic reform effort, one that has had ramifications for all aspects of life within China as well as for China's role in the region.

Although the reform program has achieved substantial successes, China has now reached a point where future achievement will come less easily. Moreover, the decentralization of economic decision making and openness of the society has created new problems and issues. These include inflation, corruption, rapid urbanization, increased resource use and pressure on the natural environment, and questions relating to the extent independent political and cultural expression should be permitted. The rest of the Asia-Pacific region is watching to see how Chinese leaders address these issues and whether China will continue at the same pace and expand the scope of its reform efforts.

We believe the Asia-Pacific Report will help to strengthen understanding of the many achievements that are being made by the peoples and leaders of the region and of the magnitude of the challenges they continue to face. We welcome the comments and reactions of readers.
Victor Hao Li
President
East-West Center
Honolulu, Hawaii 


\section{ACKNOWLEDGMENTS}

he Asia-Pacific Report is produced by the multinational staff of the East-West Center. Overall planning and direction of this year's Asia-Pacific Report was carried out by a committee that was chaired by Seiji Naya and included Lee-Jay Cho, Robert F. Dernberger, Norton Ginsburg, Charles E. Morrison, and Webster Nolan.

Aside from the chapter authors, whose names are listed at the bottom of the corresponding chapter title page, many other individuals contributed to the research and writing effort. Shereé Groves provided general research assistance and other support to the editors, wrote background papers that contributed to chapter 1, and authored boxes 3.1 and 5.1. Nancy Young authored box 7.1. Box 8.2 was authored by Louise Fallon. Paul Clark authored box 9.1 and commented on the manuscript. Joseph Morgan authored box 10.1 and assumed responsibility for the maps. The Asia-Pacific regional maps in Part I were based on maps originally prepared by Manoa Mapworks. Laurel L. Indalecio revised these maps and prepared the maps in Part II. Pearl Imada and Janis Togashi updated most appendix tables and commented on chapter 2.

Harry Harding, author of chapter 4, drew on extensive discussions with Yanqi Tong of the Johns Hopkins University. His chapter is based in part on his recent book, China's Second Revolution: Reform After Mao (Washington, D.C.: The Brookings Institution, 1987).
William Lavely is grateful for the advice and assistance of Lee-Jay Cho and Fred Arnold in preparing chapter 6 and for the use of the materials available at the EastWest Population Institute. Allen S. Whiting and Charles E. Morrison are grateful to Thomas Biddick, diplomatin-residence at the East-West Center, for contributions to chapter 10.

William Parish read and commented extensively on draft chapters dealing with China. Others who commented on one or more draft chapters included Susumu Awanohara, Richard W. Baker, Godwin Chu, Bruce Koppel, Steven I. Levine, Surin Maisrikrod, Michael Plummer, Pushpa Thambipillai, Mark Valencia, and Yaacov Vertzberger.

The editorial and production team included East-West Center Graphics Production Services staff members Jacqueline D'Orazio, Lani Abrigana, Lois Bender, Clifford Takara and Russell Fujita, and Center staff members Dorine McConnell, Erin S. Michelson, Stuart Sakoeki, and Dorothy Villasenor. David Puhlick coordinated the editorial and production process, and copyedited the manuscript with the assistance of Faye Sotirakis.

The information and analysis in this report represents the views of its authors, not necessarily those of the members of the East-West Center's Board of Governors or of any government that contributes to the Center. 


\title{
PART I
}

The Asia-Pacific Region

\author{
The Political \\ and
}

Economic Context 


\section{The Asia-Pacific Region}

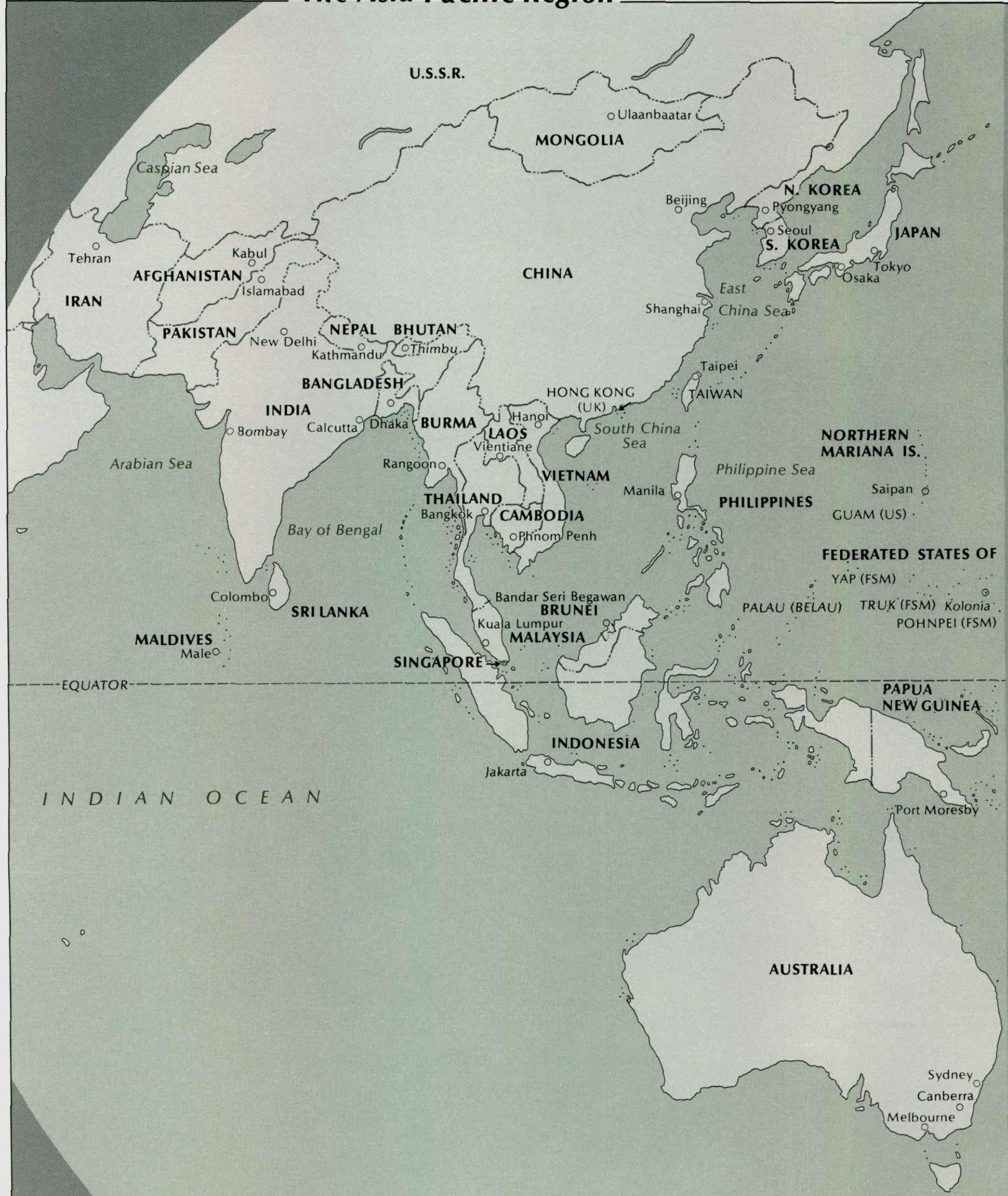




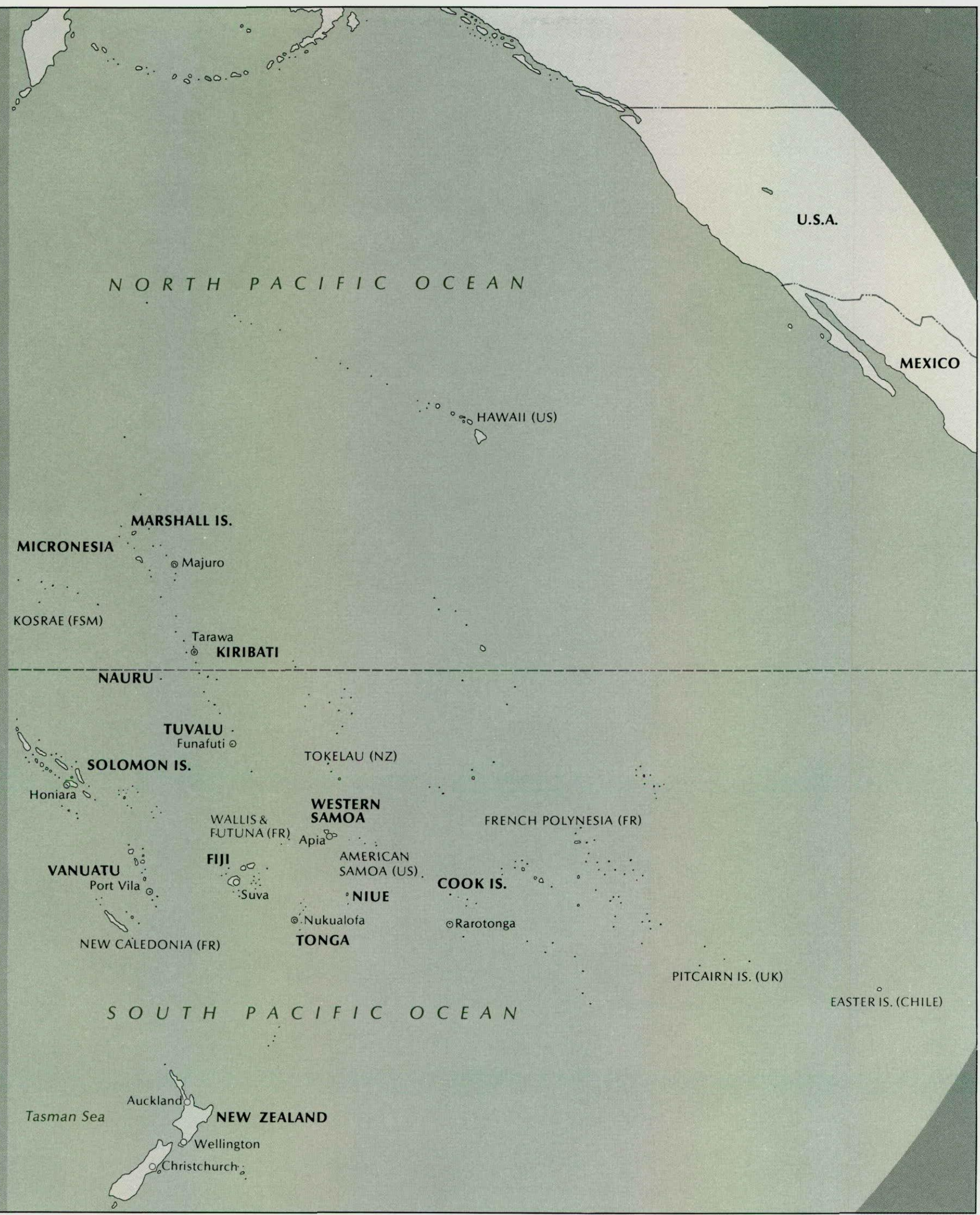




\section{CHAPTER ONE}

\section{Politics and International Relations: The Winds of Change}

$\mathbf{T}_{\mathrm{s}}$ itics and international relations of the Asia-Pacific region. Since 1985 there have been leadership changes in Japan, Pakistan, Papua New Guinea, the Philippines, South Korea, Taiwan, Thailand, Vietnam, and several Pacific island nations. Some of these changes have been politically routine leadership rotations, but others have been accompanied by major shifts in political direction. New democracies have been established in several countries, and in several others political life is being liberalized. In international relations, changes in Soviet policy and in Sino-Soviet relations is having an effect on the long-standing conflicts in Afghanistan and Cambodia as well as on tensions on the Korean peninsula.

Most, but not all, of the political changes in recent years have been associated with more open domestic politics and reduced international tension. Yet the political outlook for the region through the remainder of the century remains clouded. The winds of political change are notoriously fickle; they are subject to gusts and lulls, crosscurrents, and sudden changes of direction.

It is impossible in a single chapter to provide a comprehensive treatment of the politics and international relations of the region. Highlighted below are some countries and conflicts significant in and of themselves or illustrative of broader trends.

Chapter one was prepared by Charles E. Morrison, Coordinator of the International Relations Program, East-West Center.

\section{Domestic Politics: A Shift Toward Democracy?}

The most significant political trend at the national level has been the resurgence of democracy after 1986. In February of that year, Corazon Aquino replaced Ferdinand Marcos as president of the Philippines and restored democratic government to that country. In 1987, popular pressure forced the first direct presidential elections in South Korea, and in 1988, after the death of military leader President Mohammed Zia ul-Haq of Pakistan, the first free party-based elections in a decade brought to power a democratic, civilian government led by Benazir Bhutto. In Burma a popular uprising in the name of democracy almost overthrew Burma's military leaders and forced them to permit the establishment of opposition parties and to promise elections. Political liberalization has also been evident in Taiwan and Thailand, and even in the socialist countries of China (see chapter 4 ) and Vietnam a process of limited political reform is under way.

This is a significant shift of direction in the political history of the Asia-Pacific region. During the 1950s, 1960s, and 1970s, most of the political changes in noncommunist developing Asian countries brought to power authoritarian leaders and political institutions. The parliamentary governments of the time were notoriously weak and typically dominated by narrow-interestbased parties. In these circumstances, the military often stepped in, promising social order, national security, governmental efficiency, and economic development. By the end of the 1970 s, the military ruled directly or was the dominant political force in Bangladesh, Bur- 


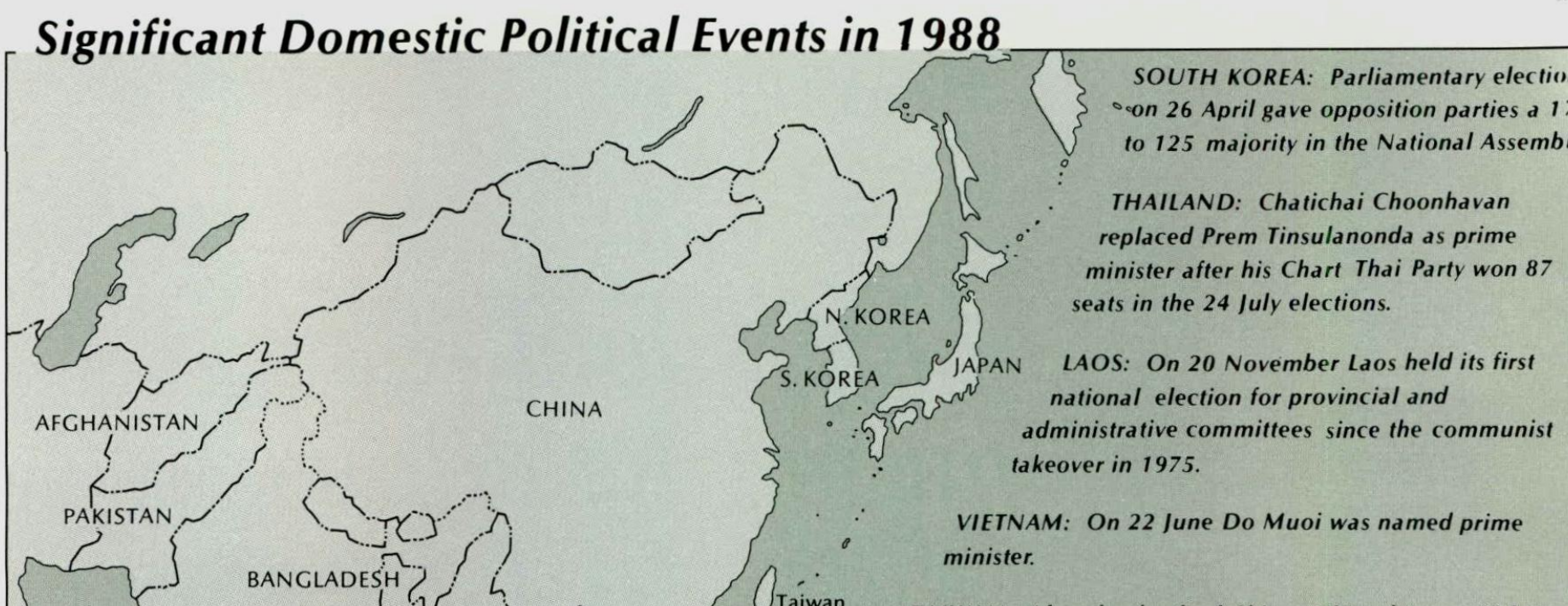

IAIWAN: After the death of Chiang Ching-kuo on 13 January Lee Teng-hui became president.

PHILIPPINES: First municipal and provincial government elections were held on 18 January.

MALAYSIA: On 4 February UMNO was ruled illegal. Prime Minister Mahathir formed UMNO Baru (New UMNO).

INDONESIA: On 10 March Soeharto was elected to a fifth five-year term as president.

AFGHANISTAN: An accord requiring the withdrawal of Soviet

forces by 15 February 1989 was signed on 14 April.

INDIA: On 11 October opposition leaders formed the Janata Pati, a coalition led by former Finance and Defense

Minister Vishwanath Pratap Singh, to contest the 1989 elections.

PAKISTAN: President Zia died in an airplane crash on 17 August. Benazir Bhutto of the Pakistan People's Party became prime minister on 2 December.

SRI LANKA: Prime Minister Ranasinghe Premadasa won the 19 December presidential elections to succeed retiring President Junius Jayewardene.

BURMA: Riots and demonstrations forced President General Ne Win to resign on 23 July. A military coup on 18 September led by Minister of Defense General Saw Maung reestablished government control.

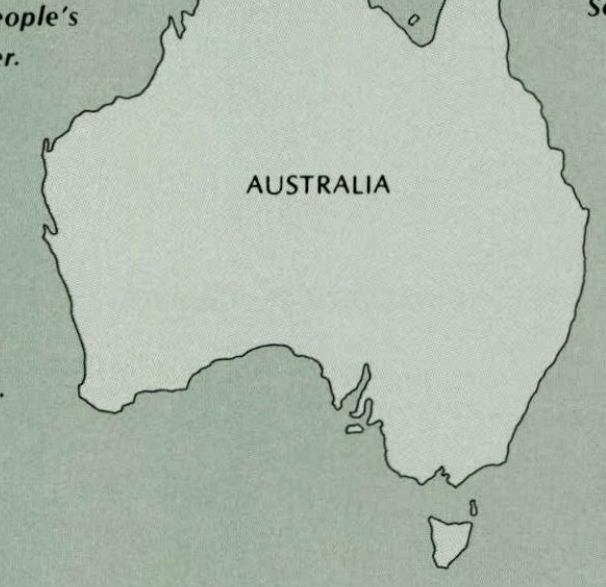

SINGAPORE: The PAP wOn 80 of 81 seats in the 3 September election.

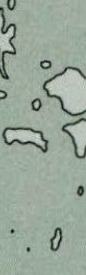

PAPUA NEW GUINEA: Rabbie Namaliu, who heads the Pangu Pati, became prime minister in July.
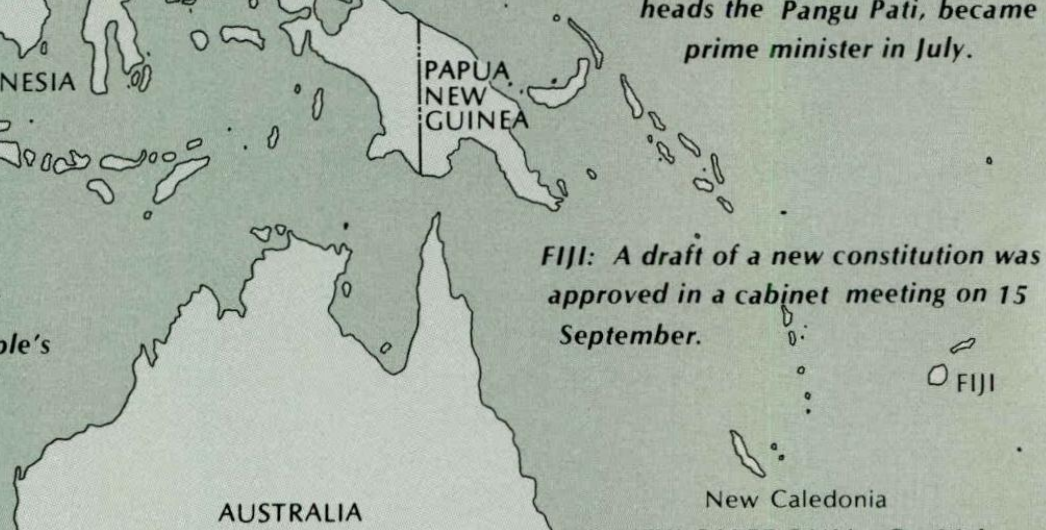

NEW CALEDONIA: On 26 June an agreement between Kanak and loyalist groups provided for limited self-rule and a vote on independence in 1998.

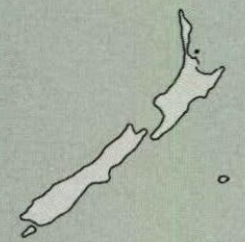


ma, Indonesia, Pakistan, South Korea, and Thailand. Civilian regimes governed under martial law conditions in the Philippines and Taiwan.

The reasons for the renewed popularity of democracy have varied from country to country. There are some general stimuli that affected more than one country.

- The rapid economic development of the region has created a more educated populace that increasingly demands the right of political participation. The demand for political rights typically has been led by university students and succeeded where the middle class joined in.

- In the Philippines and Burma, corruption, capricious policies, and poor economic performance resulted in the massive public protests that led to the downfall of Ferdinand Marcos and the near overthrow of the Burmese military-dominated regime.

- The successful political revolution in the Philippines encouraged democratic opposition from South Korea and Taiwan to Bangladesh and Pakistan. Some of the region's authoritarian governments took liberalizing measures to deflate potential political movements, hoping to emulate the Philippine example.

- In China and Vietnam, highly centralized, authoritarian government appeared to impede economic growth. Political authorities in these countries sought to decentralize economic decision making while retaining control over key political decisions.

It is too early to determine whether the shift toward more open political systems is a lasting trend for the region as a whole. The political environment is not one that is conducive to democracy. Popular attitudes toward politics, power, and authority still generally do not favor open and peaceful political competition. Most Asian cultural traditions, such as Confucianism, value harmony and order above notions of freedom and political competition. Divisive internal ethnic pressures, dangerous external environments, or the demands of catch-up economic growth have also favored authoritarian rule. In a few countries, the direction of political change is still in a more authoritarian direction. To become secure and to spread, the region's democracies need to prove that they can maintain order and provide for growth as well as guarantee freedom.

\section{Democracy on Trial: The Philippines, South Korea, and Pakistan}

Asia's three newest democracies are in the Philippines, South Korea, and Pakistan. All three countries have new leaders and new parliamentary institutions that were popularly elected. However, the political arrangements in these three countries remain fragile and not fully tested.

The Philippines. When Corazon Aquino became president of the Philippines in February 1986, the economy was in a shambles, having experienced three successive years of decline. A communist insurgency was

\section{Figure 1.1 1988 Parliamentary Results}

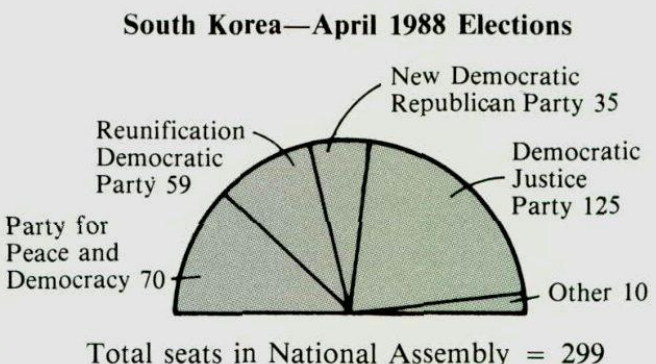

Thailand-July 1988 Elections

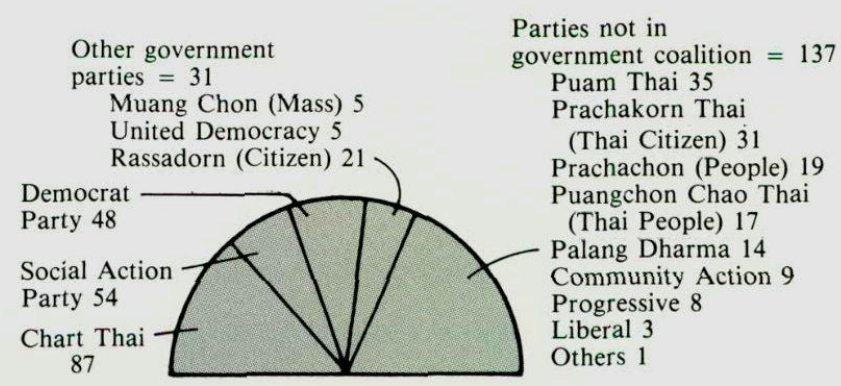

Total seats in National Assembly $=357$

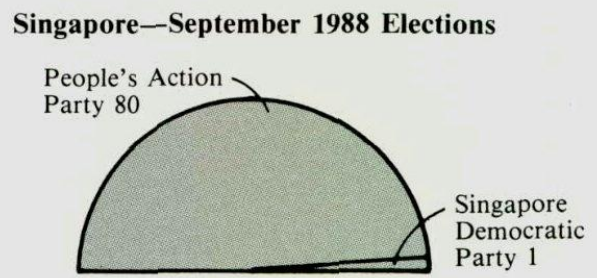

Total seats in Parliament $=81$

\section{Pakistan-November 1988 Elections}

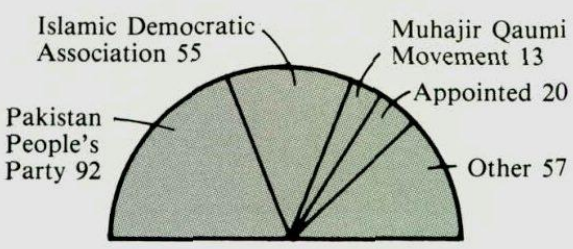

Total seats in National Assembly $=237$ 
growing. Government prestige suffered from years of corrupt administration, and it was difficult for the new government to find competent and experienced personnel who had not been tainted by close association with the previous regime. The coalition that Mrs. Aquino headed was a diverse one, temporarily held together by the belief that Marcos must go, but without a consensus on future leadership or policies.

Set against these challenges, the achievements of the Philippine government are not inconsiderable. The economy is recovering, achieving a growth rate of 5 percent in 1987 and 7.5 percent for the first nine months of 1988. The new constitution was overwhelmingly approved in a referendum in January 1987, and most of the candidates backed by Aquino won in the congressional elections of May 1987. Provincial elections were successfully carried out in January 1988 . The administration proposed and the Congress overwhelmingly passed land reform legislation that was regarded as a political imperative. Aquino has also rendered politically ineffective her most ambitious critics, including Juan Ponce Enrile, her former defense secretary and now senator, and Salvador Laurel, her vice president.

The government's sheer survival must be counted an accomplishment. There have been six attempted coups d'etat, but the chances that military dissidents could launch a successful coup against the government have been considerably diminished by the efforts of Defense Secretary Fidel Ramos. A dedicated supporter of civilian government, Ramos has placed his own allies in key positions in the military and won a pay increase for military personnel, raising their morale.

Despite its accomplishments, Aquino's administration and the democratic system that she established are still very much being tested. Although the critics who question her competence usually point to Aquino's political style, which emphasizes conciliation and decentralized authority over strong presidential leadership, the larger question is whether the new political institutions will operate effectively and credibly. There remains a full and challenging political agenda ahead.

First, the government's delivery of basic public services, especially in the countryside, remains weak. The quality and integrity of the civil service declined during the Marcos regime. Corruption will not easily be controlled. The inability of the government to administer development projects has backed up large quantities of unused aid funds. The administration of impartial justice is generally regarded as another key problem.

Second, despite improvements, the economic tasks facing the Philippines remain daunting. How well land reform will be implemented is a major question. The program requires huge amounts of capital not only to finance title transfers but also to provide the credit, ex- tension services, and other support structures needed to assist new landowners. Politically important groups oppose this and other government economic reform programs, including privatization and import liberalization. The $\$ 28$ billion foreign debt is a massive burden, absorbing 40 percent of export revenues.

Third, the communist insurgency continues to be a serious threat. Its growth appears to have been checked, at least temporarily. This reflects a more aggressive government strategy that includes cooperation with civilian vigilante groups and the creation of political action "special operations teams." The insurgency suffered from the capture of several ranking leaders and a number of documents in a Manila raid in March 1988. However, the New People's Army is believed to have more than 20,000 armed fighters and to have improved its command structure and communications. Failure of the government's economic programs or too heavyhanded tactics by the military or the undisciplined vigilante groups could refuel the revolutionary movement.

Finally, the future of the U.S. military bases is a politically sensitive and potentially dangerous issue. The Philippines and the United States were engaged in acrimonious negotiations throughout 1988 on aid levels during the final years of the existing bases agreement. This agreement expires in 1991, and under the Philippine constitution it can be renewed only by a new treaty, requiring the advice and consent of two-thirds of the Philippine Senate. If the Congress desires, it may also seek a referendum on the renewal. The hosting of foreign bases is a nationalistic issue in the Philippines that will intensify about the time of the elections to succeed Aquino whose term ends in 1992.

South Korea. The new political system in South Korea represents a compromise among political forces in that country rather than an overthrow of the ruling government. It was born out of the legitimacy crisis that President Chun Doo Hwan's government faced in the summer of 1987. When Chun proposed that Roh Tae Woo, his close friend and former military colleague, be the candidate of his ruling Democratic Justice Party (DJP) in indirect elections to succeed him, popular protests escalated. Roh realized that he could not effectively govern if he came to power under the old constitution. He defused the crisis by proposing democratic reforms, acceding to opposition demands for direct election of the president.

The opposition to the Chun government was an amalgam of forces; but in contrast to the Philippines, Korean opposition politicians could not agree on a single candidate. This allowed Roh Tae Woo to win the December 1987 presidential election with only 37 percent of the popular vote. His two principal opponents, 
Kim Young Sam of the Reunification Democratic Party and Kim Dae Jung of the Party for Peace and Democracy, won 27 percent and 26 percent, respectively. The April 1988 legislative elections followed a similar pattern. Again the DJP won a plurality of votes (34 percent, giving it 125 seats), but not a majority in the 299-seat Korean National Assembly. With a combined 174 seats, three major parties and a number of minority opposition parties control the National Assembly. The position of speaker of the assembly went to the government party, but the opposition took the two vicespeaker positions and control of nine of the sixteen standing committees.

The electoral process and other improvements in political rights appear to have increased the government's legitimacy and have given the opposition parties a base for shared participation and power in policymaking. However, South Korea's democracy remains fragile.

One weakness is that division of power may result in political stalemate or an intolerable degree of conflict. Where democracy has survived in Asia, as in Japan and India, it has been associated with a dominant political party that monopolizes both executive and legislative functions. In South Korea, these functions are not only held by different parties, but on the executive side, President Roh can hardly be a commanding figure, having been elected by only a narrow plurality. On the legislative side, the opposition majority is divided into three main parties. It is the government's hope that the smallest of these, Kim Jong Pil's New Democratic Republican Party, will support the government in the National Assembly, giving it a working majority on most issues.

The fragmentation of political power in South Korea places an especially high premium on political moderation and compromise, traditionally scarce in Korean politics. If the major political leaders cannot compete peacefully or work together within the new political framework, the system itself will be undermined.

A second weakness is that none of the political parties represents institutionalized organs capable of mobilizing sustained grassroots support for the democratic process. The only elected offices in South Korea are those of the president and National Assembly members, giving few political spoils to share with party loyalists and little incentive for extensive political organization at the local level. All the parties are based around their leading personalities who have regional bases of support.

The desire of the major South Korean politicians to avoid damaging the success of the Olympic games in September 1988 helped mute domestic political conflict in the early months after the April National Assembly elections. In 1989, however, South Korean politics is likely to become more confrontational as the new formu- las for power sharing are tested by a series of difficult political issues.

- The legacy of the Chun Doo Hwan era. Despite Chun's abject apology in November 1988 for the misdeeds of his government and exile to a rural monastery, some in the opposition want a more vigorous inquiry into corruption during the Chun period as well as a full investigation into the 1980 Kwangju incident in which at least 200 people died when the army crushed an uprising in the Cholla city. Such an investigation would not be welcomed by the Korean military and could be embarrassing to Roh Tae Woo, who at the time headed the Defense Security Command. Roh called for forgiveness of the former president and dropped many of Chun's associates from his cabinet, but by the end of the year he had failed to lay to rest the many ghosts of the Chun period.

- Social reform. Although the economy is growing rapidly, South Korean workers, especially in manufacturing industries, work long hours for low pay, often in dirty and unsafe environments. Workers, demanding a greater share of the country's prosperity, were prominent in the protests against the Chun government and have launched a series of strikes over the past two years. Despite new laws, including a minimum wage law, and rising wages, working conditions and other social reforms will remain controversial as South Korea adjusts from an authoritarian political system favoring management toward a more competitive system with greater representation for blue-collar workers.

- Inter-Korea relations. Radical student groups have made reunification the focus of their attacks against the government. Although their tactics, including efforts to march to the border for meetings with the North Koreans, have attracted little general support, there is strong public interest in improving relations with the North, especially in such areas as communications, family visits, and other exchanges that would help mitigate the national tragedy of being a divided nation. The government wants to maintain a forward-looking policy toward the North while not allowing North Korea to exploit political differences within the South's democratic system.

Pakistan. The most unexpected political transition in 1988 came in Pakistan, when strongman Zia ul-Haq, president and army chief of staff, and five other senior generals died in an unexplained airplane crash on 17 August. Zia had ruled since coming to power in a military coup d'etat in 1977. In 1985 he allowed elections on a nonparty basis and lifted martial law. The transparency of this change was evident, however, when the 
president, in an action that the Supreme Court declared after his death to have been unconstitutional but allowed to stand, abruptly sacked his civilian prime minister on 29 May 1988 for alleged incompetence and called for new nonparty parliamentary elections on 16 November.

The sudden departure of Zia left a political power vacuum and helped generate a strong public mood favoring the restoration of democracy. The acting president, Gulam Ishaq Khan, and the new army chief, General Mirza Aslam Beg, promised that the elections would be held as scheduled without military interference. The Supreme Court overturned the ban on party participation, which helped to make 35-year-old Benazir Bhutto's Pakistan People's Party (PPP) a favorite in the election.

The PPP's plurality of 92 of the 217 elected seats ( 20 others are appointed positions reserved for women) in the elections placed it far ahead of its main rival, the Islamic Democratic Alliance (IDA), which won 55 seats. However, the PPP lacked an absolute majority in the
National Assembly and won a majority in only one of the four provincial assemblies, losing the largest province, the Punjab, to the IDA.

Benazir Bhutto's future success depends on her ability to accommodate diverse centers of power and to hold together a country seriously divided politically and ethnically and facing mounting economic and social problems. The strength of other power centers was apparent in an intense post-election bargaining process in which Bhutto had to make a number of compromises before she was asked by Ishak Khan to form a government.

To reassure the military, Bhutto emphasized the importance of national defense and promised not to cut defense spending, which accounts for 34 percent of the budget. She reappointed Zia's foreign minister, Sahabzada Yaqub Khan, who underscored continuity with past foreign policies, particularly Pakistan's security ties with the United States and its policies toward Afghanistan. The civil service appreciated Bhutto's support for the election on 12 December of Gulam Ishaq

\section{Box 1.1}

\section{Asian Women Political Leaders}

The 1986 election of Corazon Aquino in the Philippines and the victory of Benazir Bhutto's Pakistan People's Party (PPP) in Pakistan's November 1988 elections place women at the apex of political life in two large Asian countries. Other women have also been prominent in Asian politics. In 1960 Sirima Bandaranaike of Sri Lanka became the world's first female prime minister, succeeding her assassinated husband. She was defeated in her effort to seek the office for a third time in the December 1988 elections as the head of the Freedom Party. Indira Gandhi served for 16 years as president of the world's most populous democratic country, India. The two largest Bangladeshi opposition parties are led by women as is Japan's largest opposition party. Aung San Suu Kyi, a daughter of independence leader Aung San, emerged as one of the principal opposition figures in Burma in mid-1988.

In a region of the world where political life is generally regarded as dominated by males, the rise of so many women in positions of political influence may appear puzzling. Most of these women leaders emerged as heirs to political movements led by their husbands or fathers, many of them assassinated. Benazir Bhutto inherited the political party of her father, Zulfikar Ali Bhutto, who was ousted in a coup attempt in 1977 and executed two years later. Corazon Aquino and Sirima Bandaranaike were housewives whose political careers began when their husbands were murdered. Hasina Wajed, leader of Bangladesh's Awami League, is the daughter of Bangladesh's first president, Sheikh Mujibur Rahman, who was assassinated in a military coup; and Khaleda Zia, leader of the Bangladesh Nationalist Party, was the wife of President Ziaur Rahman, who died in a 1981 coup attempt.

The prominence of these women also attests to their political acumen. Although most of them initially came to public prominence because of a relationship to a famous husband or father, they have proved successful in their own right in the politics of their respective societies. Indira Gandhi had a reputation as one of the world's toughest politicians. Under the tutelage of her father, Pundit Jawaharlal Nehru, Gandhi was actively involved from an early age in the struggle for independence and in post-independence politics, rising to a ministerial position under Nehru's successor. Although often at first lightly regarded as a politician, Corazon Aquino survived numerous challenges from within and outside her governing coalition and consolidated her position as president of a once shaky government. Benazir Bhutto's electoral victory caps a long struggle. Over the past year, both before and after former President Zia's death, she developed political positions that made the PPP acceptable to a broad segment of Pakistani society and built electoral alliances that firmly established it as Pakistan's leading party.

Bhutto is the first woman prime minister of an Islamic country. She writes in her recent autobiography, Daughter of the East, that "Muslim history was full of women who had taken a public role and performed every bit as successfully as men. Nothing in Islam discouraged them, or me, from pursuing that course." 
Khan, a former bureaucrat, as president. To reassure the business community, Bhutto backed away from the socialist positions of her father, former Prime Minister Zulfikar Ali Bhutto who was executed by Zia in 1979. Many of the PPP's candidates and most of its ministers are drawn from the powerful landowning classes.

The central government's relationship with the Punjab state government led by Nawaz Sharif, Bhutto's chief political rival, will require particular political skill of the new prime minister. It is unprecedented in Pakistan to have the central government controlled by one party and the Punjab government controlled by another. The rivalry that this would be expected to generate under the best of conditions will be compounded by ethnic differences between the Punjabis, who dominate the military and civil service, and the Sindhis, Bhutto's own ethnic group and major base of support.

Pakistan is entering a period of serious economic difficulties. Salary remittances from its overseas workers in the Middle East, once equal to almost 10 percent of gross national product, fell sharply with the decline in Arab oil revenues. Foreign assistance, boosted by Pakistan's frontline position during the Afghanistan war, may also fall. Bhutto has outlined an ambitious socioeconomic program, including universal education, half a million new houses, and large capital investments in industry, but it will be virtually impossible to achieve unless tax revenues are substantially boosted.

In an address after her inauguration, Bhutto described Pakistan as "on the brink of catastrophe." The new prime minister faces an especially challenging task in proving that democracy can work in a country where the military remains a strong and cohesive political institution and has controlled government longer than elected civilian politicians.

\section{Evolutionary Political Liberalization: Taiwan and Thailand}

Most noncommunist Asian authoritarian governments are or claim to be systematically moving toward participatory government consistent with conditions and traditions in their societies. In the Philippines and South Korea, the steps taken by the Marcos and Chun Doo Hwan governments were regarded as too minimal, and large-scale popular demonstrations forced a change. Elsewhere in Asia, however, several other governments are engaged in what have so far been successful efforts at political liberalization. In Taiwan, the ruling Kuomintang leaders themselves have been in the vanguard of political reform, and in Thailand there has been a gradual evolution toward an open and stable political system based on power sharing between the military and civilian politicians.

Taiwan. Clearly, events in the Philippines and South Korea have influenced recent political developments in Taiwan. However, there was also an evident internal need for political reform in Taiwan in response to popular pressures. Until recently, the Kuomintang ruled by martial law, first declared in 1949, and no opposition political parties were permitted. The elected institutions were dominated by elderly incumbents who had been elected by their mainland constituencies in 1947. Not only were they not being reconfirmed through an electoral process since fleeing to Taiwan, but they represented mainland domination of the political life of the island.

In the mid-1980s, President Chiang Ching-kuo initiated the process of political modernization in the face of conservative opposition within the ruling Kuomintang Party. This process is notable in two respects: political life is being liberalized, and native Taiwanese are playing a much greater role in the politics of Taiwan.

In 1986 the opposition was allowed to organize a political party, the Democratic Progressive Party (DPP), and in 1987, martial law was lifted. Some restrictions on the press were abolished. Chiang, the son of longtime Kuomintang leader Chiang Kai-shek, also made it clear that there would be no dynastic succession. When he died on 13 January 1988, he was succeeded by his vice president, Lee Teng-hui, a native Taiwanese.

The Kuomintang, in contrast to South Korea's Democratic Justice Party, is a highly organized political institution that appears to be successfully completing a transfer of power to a younger generation of political leaders. Although Lee Teng-hui at first was regarded by some analysts as a transitional figure, he moved quickly to strengthen his political position within the party. In July 1988 the 13th National Congress acclaimed Lee as Kuomintang chairman and, as a result of the first free elections in the party, which is organized on Leninist principles, chose a new central committee. Native Taiwanese membership on the Central Committee sharply increased from 20 percent to 45 percent and the average age of the members decreased from 70 to 59. Native Taiwanese also gained, for the first time, a 16-person majority in the 31-member Standing Committee. Shortly after the Congress, Lee reshuffled his cabinet, retaining conservative Prime Minister Yu Kuohwa but bringing younger persons into a number of important positions including the first woman cabinet member as finance minister.

The new Kuomintang leader still faces the delicate challenge of continuing the liberalization process while not alienating the older, more conservative, mainlander Chinese leaders. One task is to retire elderly mainland 
members of the Legislative Yuan and other councils. This is complicated in that these bodies are intended to represent China as a whole, and the Kuomintang believes that it would lose its legitimacy if it gave up its claim to be China's national government.

Relations with Beijing remain sensitive. The government officially continues to rule out direct contact, negotiations, and compromise with the mainland. However, a significant change has occurred. Not only can people from Taiwan visit the mainland, and many do, but on a case-by-case basis mainlanders are allowed to enter Taiwan to visit sick relatives or attend funerals. Indirect trade is rapidly expanding, in part because Taiwan does not want to deny itself access to mainland China's growing market or cheap raw or processed industrial materials.

As actual contacts grow, policy innovation is being stalemated by internal differences within the Kuomintang between younger and older generations and between mainlanders and Taiwanese. The opposition has also been divided on its position on Taiwan's future relationship with the mainland; a minority faction of DPP radicals sought to capitalize on Taiwanese independence sentiments, but in October 1988 the party's national congress backed away from this divisive issue by electing a new chairman committed to a more moderate program of political reforms and dialogue with the Kuomintang.

The question of policy toward the mainland remains a major, unresolved political question in Taiwan and one that may become more, rather than less, difficult to resolve in a liberalized political system. The People's Republic of China, for its part, has welcomed the trend toward increased unofficial contacts across the Taiwan Straits and firmly rejects independence for Taiwan.

Thailand. Since the Second World War, Thailand has oscillated between authoritarian and democratic governments; the democratic period from 1973 to 1976, for example, was abruptly terminated by a military coup d'etat in the wake of increased social conflict. The current constitution reflects military dominance, but political parties are free to organize and contest elections for seats in the lower house of the National Assembly. Governments are based upon majority support in this house. The press is free to criticize the government and helps both to promote political debate and to publicize wrongdoing.

Thailand's democratic system took a step forward on 4 August 1988, when Chart Thai party leader Chatichai Choonhavan became the country's first elected prime minister since 1976. Chatichai, a businessman who has also been a military of ficer and diplomat, succeeded General Prem Tinsulanonda, who had served as prime minister since 1980 but who had never stood for election. Although Chatichai and the other leaders of parties commanding a majority of votes in the National Assembly after the 24 July elections would have supported Prem for another term, Prem turned down their offer in the midst of mounting public sentiment that an elected member of Parliament take the position.

Chatichai's strengths include his acceptance by the Thai military (although he retired from active duty in 1958) and the business community. He has successfully built the Chart Thai into Thailand's largest political party, holding 87 of the 357 assembly seats, but he faces a demanding challenge in providing stable, efficient parliamentary government. Chatichai must not only maintain the support of the major parties in his six-party governing coalition, but his government will be dependent on a substantial degree of internal discipline and unity within these parties. Thailand's political parties have not been noted for these qualities; Prem dissolved the previous government partly because he could not count on the support of a dissident faction within the then-largest political party in the government coalition, the Democrats.

The maturing of the Thai political parties is crucial to the viability of the present constitutional system. The democratic period from 1973 to 1976 was characterized by short-lived governments and social instability. The Thai media and society generally view politicians and parties as self-serving. Past military intervention in government exploited the negative image and performance of the political parties. The 1988 election, like ones before it, was characterized by widespread vote buying. Chart Thai's close association with business interests reinforces the self-serving image, a major contrast from Prem's reputation as a nonpartisan "Mr. Clean." To be successful, the new coalition will have to demonstrate that it is concerned with broad public policy concerns and national interests. In the long run, Thai democracy would be helped by a smaller number of parties commanding broader bases of political support.

\section{A Failed Revolution in Burma}

The region's most dramatic political events of 1988 occurred in isolated Burma. Since the military coup of 1962, Burma had been ruled by General Ne Win. The military government established its own political instrument, the Burma Socialist Party Program (BSPP), and abolished political parties. The private sector of the economy was virtually eliminated as the military leaders pursued the Burmese "way to socialism:"

A growing economic crisis, accentuated by unpredictable government policies, led to a political crisis that reached a climax in mid-1988. Opposition grew as a 
result of food shortages and unpopular policies, such as the government's abrupt decision on 5 September 1987 to invalidate all currency notes over 15 kyats, invalidating three-fourths of the country's cash. Riots broke out in March and June 1988, in which, unlike less serious riots in earlier years, more than just the student community participated.

As unrest widened, Ne Win announced his resignation at a special meeting of the BSPP on 23 July 1988. He was succeeded by an associate, General Sein Lwin, who attempted to deal with the situation by cracking down on dissidence with a heavy hand. This only increased resistance, and Sein Lwin in turn resigned on 12 August to be replaced a week later by a civilian BSPP leader, Attorney General Maung Maung Kha. Although Maung Maung promised multiparty elections, the demonstrators overestimated their bargaining position by insisting that such elections should not be held under the auspices of a BSPP regime and demanded that an interim government be established.

The Burmese military leaders faced the question of conceding or renewing their efforts to suppress revolt. On 18 September, in a move widely believed to be or- chestrated by $\mathrm{Ne}$ Win, they reasserted their role, replacing Maung Maung with Saw Maung, the army chief of staff and minister of defense. This coup, made in the name of restoring law and order, was accompanied by tough measures to limit dissent, including the shooting of hundreds of demonstrators.

The rebellion in Burma was a spontaneous one, fostered by misgovernment and economic hardship. Because the BSPP had allowed no opposition for years, there was no organized opposition movement or, at the beginning, real opposition leaders. Some leaders emerged, such as former Prime Minister U Nu, former Defense Minister Tin Oo, and Aung San Suu Kyi, the daughter of independence leader Aung San. However, the disunity of the opposition and the ability of Burma's military leadership to retain control of their troops decided the contest, at least in the short term, in the government's favor.

The events in Burma show that long periods of military domination can mask an underlying political instability. Most Asian military regimes establish avenues for participation by civilian politicians, either through government parties or in weak opposition groups. These

\section{Box 1.2 \\ Cautious Political Change in Vietnam}

The Socialist Republic of Vietnam is experiencing political and economic change associated with a generational transfer of power and serious economic problems. This change was touched off by an economic self-criticism campaign that began in late 1985 and the death of the party General Secretary Le Duan in July 1986. In December 1986, at the 6th Congress of the Communist Party, four senior Politburo members resigned and five new members were added. In February 1987, in a government shuffle, twelve ministers and two state commission chairmen were ousted and the bureaucracy was streamlined in an effort to promote more reform-minded cadres. In May 1988, three deputy premiers were fired after being blamed for falling food production and a tardy response to food shortages in the north. Purification campaigns to weed out corruption have been launched against lower-level party and government officials.

Nguyen Van Linh, who was named party general secretary at the 6th Congress, is an economic pragmatist who has promoted the doi moi, or economic "renovation" campaign. Economic reform in Vietnam, however, has had little success. Vietnam's military intervention in Cambodia prevents significant improvement in the country's relations with most of its Asia-Pacific neighbors and with the West and continues to drain the economy. Moreover, doubts remain about the commitment of the political leadership to an aggressive reform program.
The cautious approach was underscored by the choice of two older revolutionaries, Vo Chi Cong and Pham Hung, to be president and premier in June 1987. When Hung died in March 1988, Vo Van Kiet, a leading reform advocate, became acting premier. However, in June, when the National Assembly met to select a permanent replacement, Kiet was defeated by Do Muoi, a long-time party faithful. Vietnam's style of collective political leadership obscures the importance of any single individual, but Muoi's selection was regarded by some observers outside Vietnam as a sign that the country would continue to pursue a cautious, step-by-step approach to reform.

There have been other signs of gradual liberalization. In February 1988 Hanoi relaxed some travel restrictions and announced the release of a number of detainees including high-ranking officials of the former South Vietnamese government. There has been some relaxation of restrictions on cultural expression, although this has not been consistently pursued. Vietnam continues to search for a consensus on national direction, an effort complicated by generational differences, divergent outlooks in the northern and southern parts of the country on economic issues, and unresolved questions about the relative priority of defense and the economy. General Secretary Linh's ill health and request to retire in early 1989 will prompt other leadership changes affecting the balance between conservatives and reformers. 
may defuse pressures for wider participation and help keep the government leaders on their toes. However, the longer-term viability of such arrangements is questionable. They may not offer enough access, representation, or political expression to outside groups to maintain legitimacy, and without an effective safety value, an explosion can occur.

In Burma's case, the inner circle of political rulers has been especially closed, and it is uncertain to what extent it will be broadened. The strength of the rebellion forced the military to remove its political mask, the BSPP, and to take repressive measures that may only provoke deeper bitterness. The military government continues to promise multiparty elections, but no date has been set. The BSPP was renamed by the National Unity Party, and many small opposition parties have been allowed to register. However, without a strong program of economic and political reforms to accompany the crackdown, including a real right of representation for groups outside the narrow military governing circle, it seems unlikely that the current leadership can long maintain its position.

\section{A Crosscurrent: Malaysia, Singapore, and Fiji}

Not all Asia-Pacific countries have shared in the regional trend toward political liberalization. There has been a tightening of political controls in Malaysia, Singapore, and Fiji, countries that have some of Asia's strongest democratic traditions. Malaysia and Singapore have regular free elections contested by government and opposition parties, and Fiji hopes to restore elected government by the end of 1989. Ethnic tensions are the basic political threat in all three countries and also the justification for limitations on freedom of the press or the use of special internal security powers. Although interpretation of the events in these countries frequently stress the political ambitions of individual leaders, obvious or latent social tensions are probably more important in explaining shifts in the political climate.

Malaysia. Despite Malaysia's regular elections and the three peaceful changes of the prime ministership since independence in 1957, the government has incrementally expanded its powers of arrest and restrictions on free speech and the press. The Internal Security Act (ISA), as in Singapore, is a legacy of British rule and the 1948-60 communist insurgency. Constitutional amendments were passed after serious race riots in May 1969 to prohibit public discussion of sensitive issues pertaining to race relations. Every Malaysian government has used these powers, but recently their use has been expanded. This may be related to a breakdown in the patterns of political accommodation that characterized the earlier post-independence years and in the broadening of the politically active population, particularly among the Malays.

The ISA was invoked most dramatically in late 1987 following the buildup of racial tensions triggered by the promotion of non-Mandarin-trained teachers in Chinese schools. Police detained 106 persons, including 10 federal parliamentarians from the opposition Democratic Action Party. The party and deputy party leaders have since been sent to prison for two years. The licenses of three newspapers were temporarily revoked for inciting racial tensions. The government also amended the law to require newspapers to apply for license renewals each year, strengthened provisions in the Official Secrets Act that allow the classification of information, and tightened police control over political gatherings.

Turbulence in Malaysian politics was heightened by an open split within the mainstream Malay political elite. In April 1987, former Minister of Finance Tengku Razaleigh Hamzah narrowly lost a party election to replace Mahathir as president of the politically dominant United Malays National Organization (UMNO) and thus as prime minister. After Razaleigh's supporters challenged the vote in the courts, the court ruled that because some party branches had not been registered as required by law, UMNO itself was illegal. This prompted both main factions to rush to register UMNO under new names.

The Registrar of Societies, an official of the Home Ministry headed by Mahathir, refused to register Razaleigh's UMNO Malaysia and instead registered Mahathir's UMNO Baru. This gave Mahathir an unchallenged position within the new Malay governing party and completely excluded his opponents. While this action was being challenged in the courts, Mahathir suspended the head of the Supreme Court and five other Supreme Court justices, later dismissing three of them. In September, Razaleigh's supporters crossed over to the opposition benches of Parliament, formalizing the intra-UMNO split.

The Malaysian political process, particularly relations within the ruling Malay party, traditionally has been characterized by a high degree of accommodation. The intraparty dispute, the struggle between Mahathir and the judiciary, and the wide use of the ISA introduces a new, more confrontational politics.

Singapore. In small Singapore, political power is highly concentrated. The People's Action Party (PAP), under Prime Minister Lee Kuan Yew, for many years displayed strong collective leadership and was virtually synonymous with the government, winning every 
parliamentary seat between 1968 and 1981. The PAP's margin of victory fell from 75 percent in the 1981 election to 63 percent in 1984, when two seats were lost to the opposition. Despite speculation that the opposition might make further inroads in the September $1988 \mathrm{elec}-$ tions, the PAP won 80 of 81 seats and 62 percent of the vote, proving that it remains overwhelmingly the popular choice for government in the city-state.

Despite this, the Singaporean government is sensitive to criticism and fears that strong, emotionally laden forces of racism or Marxism could undermine stable government. One of the two opposition members of Parliament elected in 1984 was required to give up his seat in 1986 after he was fined for allegedly falsifying party accounts. A new press law was used to restrict the circulation of four foreign publications-The Asian Wall Street Journal, Asiaweek, The Far Eastern Economic Review, and Time. Like Malaysia, there has been an upsurge in the use of the ISA, allowing detention without trial. In May and June 1987, twenty-two people, mostly young lawyers and social workers, were detained for allegedly plotting to overthrow the government, and eight of these were rearrested in April 1988 after accusing the government of mistreating them. While petitioning for the release of two of the detainees, a lawyer, Francis Seow, was also arrested and detained for 72 days under the ISA for alleged involvement with an American embassy official in a scheme to interfere in Singapore's domestic politics.

PAP leaders maintain that their objective is to achieve more participatory democracy over time but argue that Singapore's society is not yet mature enough to permit free, public discussion of sensitive issues. Part of the reason for the PAP's sensitivity to criticism may be that it is currently engaged in a transfer of political power to a younger generation of leaders. Fourteen PAP members did not stand for reelection in 1988, including all of the remaining founding members except for Prime Minister Lee Kuan Yew.

Despite speculation that Lee might retire as prime minister after he turned 65 in September 1988, his designated successor, First Deputy Prime Minister Goh Chok Tong, asked Lee to stay on "for up to two years." Lee also retains his key party position as the PAP's secretarygeneral. Nevertheless, the September election was interpreted as a victory for the "new guard" team led by Goh, and Goh is being thrust forward as the key policymaker in the country. A planned process of succession in Singapore appears well under way. There is speculation that Goh may bring to the Singapore scene a more relaxed, collegial style of leadership.

Fiji. Fiji's democratic system ended after the April 1987 elections in which the Alliance Party, which had governed since independence in 1970 under the leader- ship of Prime Minister Ratu Sir Kamisese Mara, was defeated by a coalition of the National Federation Party and the Labour Party. The new coalition, led by a Melanesian Fijian chief but based on electoral support from Indian Fijians, appeared to many Melanesians (46 percent of the population) to be transferring political power to ethnic Indians (48 percent of the population). Underlying the racial tensions is deep anxiety about land rights. Melanesians own the land but lease much of it to Indian farmers with no guarantee that lease arrangements will be renewed on expiration. The new government's promise to look into land questions with a view toward stabilizing the rights of Indian farmers created fears among Melanesians that their land rights, the basis of their economic and political power, would be taken away from them.

After several weeks of racial unrest, the new government was overthrown on 14 May by 38 -year-old Lieutenant Colonel Sitiveni Rabuka, who promised to amend the constitution to ensure Melanesian political control. An interim government was established under Governor-General Ratu Sir Penaia Ganilau, but when Ganilau sought to establish a bipartisan council of government, restore the democratic process, and share power with the Indian community, Rabuka staged a second coup on 25 September. This time the constitution was abolished; and Fiji was declared a republic and left the Commonwealth of Nations.

Because of serious economic problems and lack of external support, in December Rabuka dissolved his government and formally returned power to senior Melanesian civilian leaders: Ganilau was declared president, and Mara was appointed prime minister by Ganilau. Rabuka, however, remained commander of the armed forces and was appointed minister of home affairs, thus retaining effective power.

Fiji's political future remains precarious. The Ganilau-Mara government has been under pressure from some within the military and the Melanesian nationalist Taukei movement who believe a third coup may be necessary to ensure ethnic Fijian dominance. Some members of the Indian community have allegedly been illegally importing weapons.

It was only in September 1988 that the interim cabinet approved a draft constitution, which is a necessary step toward a return to elected government in Fiji. This draft is designed to ensure Melanesian political domination by maintaining separate voting roles for Indians and Melanesians and including 12 appointed members in a 71-member unicameral parliament. It also gives the president and commander-in-chief, both appointed by the Great Council of Chiefs, wide emergency powers.

Many questions remain. Will the new consitution be seen as legitimate beyond the ethnic Fijian communi- 
ty? How will it work in practice? Can a viable party system, including opposition parties, be restored? And will a new political order stem the outflow of skilled and professional people and the resulting erosion of the country's modern economic base? The road back to democracy in this almost equally divided nation is fraught with perils.

\section{An Asian Political Model?}

The liberalization of political power in some of the Asia-Pacific region's traditionally authoritarian countries and the curtailments on political expression in some of the traditionally more democratic states suggest a possible convergence of political systems. At some time in the future an Asia-Pacific model of politics may emerge, perhaps along the lines of the democratic systems of Japan and India, each with a single dominant political party rather than an alternating two-party system more familiar in the West. At present, however, the political life of the region remains incredibly diverse, and the shift toward democracy in much of the region may yet be reversed unless the new democracies also provide effective government.

\section{International Relations: Improving Prospects for Peace}

The basic pattern of international relations in the AsiaPacific region through the 1970 s and into the 1980 s has been shaped by two competitive large-power relationships: one between China and the Soviet Union and the other between the United States and the Soviet Union. This pattern is being modified as tensions in both relationships have moderated. For the first time since the late 1940s, China, the Soviet Union, and the United States are engaged in substantive bilateral dialogues with each other on a broad range of global and regional issues. Japan, an emerging political power in its own right, is allied with the United States, has good relations with China, and has correct but cool relations with the Soviet Union. The improved relations among the larger powers has important implications for several long-standing areas of regional tensions-Afghanistan, Cambodia, and the Korean peninsula.

\section{Soviet Policy: A Change of Direction}

The recent reduction of large-power tensions is primarily due to a shift in Soviet policy. The Soviet Union has been the odd man out in large-power poli- tics in the Asia-Pacific region. The United States and Japan normalized their relations with China during the 1970s. Although the Soviet:Union dramatically increased its military forces in Asia, it was unable to convert military might into increased political influence. At the end of the 1970s, direct Soviet military intervention in Afghanistan and financial support for the Vietnamese invasion of Cambodia further isolated the Soviet Union from the other large powers and from most Asia-Pacific countries.

Soviet efforts to improve its diplomatic position in the region can be traced to the early 1980s. After Mikhail Gorbachev came to power they were pursued with more vigor. In his first comprehensive statement on Soviet Asia-Pacific policy on 28 July 1986 at Vladivostok, Gorbachev struck a conciliatory tone and suggested a number of areas for possible cooperation between the Soviet Union and its regional neighbors. The reactions in much of the region were politely positive, but Asia-Pacific leaders stressed that there needed to be follow-up on the concrete issues of concern to them, particularly Afghanistan and Cambodia.

In the two and a half years following the Vladivostok speech, the Soviet Union has made progress in these areas. It signed accords on Afghanistan, requiring a complete withdrawal of its troops by February 1989. Pressure has been put on Vietnam to begin withdrawing its troops from Cambodia. Under pressure from U.S. negotiators and with the support of China and Japan, the Soviet Union agreed to the elimination of its intermediate range SS-20 missiles in Asia as part of the Intermediate Nuclear Forces (INF) Treaty with the United States. Improvements in Soviet-Asian relations have proceeded most rapidly with respect to China, the main focus of its diplomatic attentions (see chapter 10). The least change has occurred in Soviet-Japanese relations because of Soviet reluctance to consider Japan's territorial claims to the four northern islands held since the Second World War.

The Soviet Union's relations with China, Japan, and the United States remain largely competitive. There remains skepticism in these countries about Gorbachev's underlying motives and of his ability to carry out policies of real economic and political reform that would be conducive to significantly expanded and improved external relations. Nevertheless, the changes in Soviet policy that have already taken place are having important international implications.

\section{Regional Conflicts}

The resolution of existing Asia-Pacific regional conflicts in Afghanistan and Cambodia involves two chief problems: first, how to decouple the larger-power rivalry 
from the conflict, and second, how to reconcile the local protagonists. Because of the Soviets' desire to reduce losses in these regional conflicts, the first problem seems more easily resolved than the second.

Afghanistan. Six years of negotiations finally led to a four-part accord on Afghanistan, signed on 14 April 1988 by representatives of Afghanistan, Pakistan, the United States, the Soviet Union, and the United Nations. Afghanistan and Pakistan pledged not to interfere in each other's domestic affairs and to ensure the voluntary, orderly, and peaceful repatriation of Afghan refugees. The United States and the Soviet Union guaranteed not to interfere in the internal affairs of either country. A related Soviet-Afghan agreement required Soviet troops to be completely withdrawn by 15 February 1989. The United States and Pakistan promised to stop the flow of arms to the Afghan resistance forces, but the United States reserved the right to recommence the supply if the Soviet Union supplied arms to the Kabul government.

The accords were made possible by Soviet willingness to withdraw its troops even if it meant sacrificing the communist Kabul regime of General Najibullah. This permitted bypassing a key question-the future of the Afghan government-leaving it for future resolution. There are at least three major local elements in Afghanistan with different interests: (l) the communist government, itself divided between the Parcham and Khalq factions; (2) the Pakistan-based seven-member resistance coalition (Mujahidin), four of them commonly regarded as fundamentalist Islamic groups and three, as traditionalists; and (3) the guerrilla field commanders in Afghanistan who have grown increasingly influential as the Soviets withdraw.

As the Soviet withdrawals began, the United Nations' representative for Afghanistan, Diego Cordovez, sought to promote a coalition government based on the principle that no group would dominate. He has achieved little progress. The Najibullah government welcomes a coalition but wants to retain key government positions and instruments of power under its control. The fundamentalist leaders, sensing victory, oppose communist participation in any coalition government. Some also seek a new kind of Islamic state and oppose suggestions to return to the traditional monarchy. The Mujahidin do not recognize the 1988 accords, in which they did not play a direct negotiating role, and have vowed to fight on until their ideal is achieved.

Despite the withdrawal of Soviet troops, bloodshed in Afghanistan seems likely to continue. Some analysts believe that the war has helped produce both in Kabul and among the Mujahidin a new sense of Afghan nationalism that may ultimately prove beneficial to the development of a unified Afghan nation. In the mean- time, there remain many competing visions of what that nation should look like and no political process for resolving these differences peacefully.

Cambodia. The Afghanistan accords raised hopes for a similar agreement on Cambodia, where since December 1978 as many as 140,000 Vietnamese troops have sought to suppress guerrilla warfare carried on by three Thai-based resistance groups loosely united in the Coalition Government of Democratic Kampuchea. The conflict shares some features with that in Afghanistan. The Soviet Union is a major financial supporter of the Vietnamese effort, and Gorbachev's desire to reduce the economic and diplomatic burdens of involvement have led him to put pressure on Vietnam.

There are several important differences with Afghanistan. Vietnamese, not Soviet, troops are in Cambodia. The resistance is mainly supplied by China, not the United States. Very importantly, the political future of Cambodia without foreign troops cannot be ignored because the militarily strongest resistance faction is the Khmer Rouge, which ruled Cambodia in a reign of terror between 1975 and 1979. It would be unacceptable to Vietnam, the member countries of the Association of Southeast Asian Nations (ASEAN), and the superpowers if this group were to regain power in the wake of a Vietnamese withdrawal.

The Vietnamese government stated that it would withdraw 50,000 troops by the end of 1988 and all its troops by the end of 1990 , and possibly as early as September 1989 if a political settlement is achieved. Although since 1982 Vietnam has periodically announced troop withdrawals that have been merely rotations, in 1988 some troops did leave. Several factors have led to the withdrawal: Soviet pressure; Vietnam's exhaustion, economic difficulties, and anxiety to divert funds to pressing domestic needs; and perhaps a desire by the Vietnamese government to overcome its diplomatic isolation from the ASEAN group and their supporters. Vietnamese leaders may also believe that the Vietnamsupported Phnom Penh government is, or by 1990 will be, strong enough to contain the resistance on its own.

Three sets of discussions have begun. Prince Sihanouk, a leader of one faction and until July 1988 the head of the resistance coalition, initiated bilateral negotiations with Hun Sen, Phnom Penh's premier, in late 1987. Son Sann, the leader of another noncommunist resistance faction, joined this dialogue in November 1988. Parties to these negotiations agreed to establish a "working commission."

Second, the first meeting between the Vietnamesesupported Phnom Penh faction and all three resistance factions took place outside Jakarta, Indonesia, from 24 to 28 July 1988 . These talks were joined in a second stage by representatives of Vietnam and the ASEAN 
countries. A second Jakarta Informal Meeting (JIM) took place in February 1989.

China and the Soviet Union have also been discussing Cambodia, which the Chinese identified as the principal obstacle to the normalization of Sino-Soviet relations. At a meeting of the foreign ministers of the two countries in early December 1988, it was agreed "to facilitate the solution of the external aspects" of a Cambodian settlement.

There are many obstacles to a successful conclusion. Vietnam and the Phnom Penh faction would like to incorporate Sihanouk and other acceptable figures from the resistance groups in a new government but deny them real power. The ability of Sihanouk and Son Sann to demand positions of real influence in any future coalition government are limited by the military weakness of their own factions.

More complex still is the role of the Khmer Rouge in a future government. As a resistance faction, the Khmer Rouge is a party to the negotiating process and is acknowledged as deserving of a role in a future coalition government. However, it was agreed in Jakarta that there should be no recurrence of "genocidal policies and practices of the Pol Pot regime" (the 1975-79 Khmer Rouge government). The distinction between acceptable Khmer Rouge participation and a role that might threaten the return of genocide has not been defined. The fear of Khmer Rouge domination could be reduced if the faction's leaders are given exile outside Cambodia and their military force neutralized. However, proposals to merge the four factions' military forces, disarm them, or establish an effective international peacekeeping force appear unrealistic.

China, as the principal military supplier of the Khmer Rouge, and Vietnam, as the foreign military presence in Cambodia, have critical roles to play. These two countries, however, were long the missing link in the negotiating process. Although China's leaders have softened their support of the Khmer Rouge (see chapter 10), they have said that there will be no Sino-

\section{Box 1.3 India's Role in the Subcontinent's Security}

One trend, unaffected by the relations between the superpowers, has been for India to increasingly assume the responsibility for regional order in South Asia. This role has been underscored by recent Indian interventions in Sri Lanka and the Maldives, both in response to invitations by the governments of those countries.

Since 1983, Sri Lanka has experienced a virtual civil war involving Sinhalese-dominated government forces and militant Tamils seeking a separatist state in the Northern and Eastern provinces. The Tamil separatists received support and, in the past, training at bases in the Indian state of Tamil Nadu. However, as leader of a multiethnic state, Indian Prime Minister Rajiv Gandhi could not afford to encourage separatism nor did he want more distant countries to intervene in the conflict. Consequently, he sought to play a mediating role between Sri Lankan President Junius Jayewardene and the Sri Lankan Tamil minority.

In the 29 July 1987 accord between India and Sri Lan$k a$, Jayewardene agreed to establish an autonomous Tamil region comprised of the Northern and Eastern provinces. As provided for in the accord, several thousand Indian troops entered Sri Lanka shortly afterwards to assist in the disarmament of the Tamil insurgents. The most militant Tamil group, the Liberation Tigers of Tamil Eelam (LTTE), refused to surrender their weapons and declared war on the Indian peacekeeping forces. Contrary to initial expectations, as many as 50,000 Indian troops had to be sent to Sri Lanka to suppress the LTTE.

Although Indian forces sufficiently tamed the LTTE to permit successful elections on 19 November 1988 for a new provincial council for the north and east, there has been an upsurge in violence in the south by Sinhalese Marxist extremists opposed to autonomy for the Tamil areas and to Indian intervention. The Janata Vimukthi Peramuna, or People's Liberation Front, has been engaged in a campaign of violence to punish the Jayewardene government and to disrupt the December 1988 presidential elections and parliamentary elections scheduled for February 1989. To date, the violence has claimed more than 500 lives. The new president, Ranasinghe Premadasa, aims to remove foreign forces. An Indian withdrawal of two battalions was announced shortly after his election. However, if the Sri Lankan government seeks to hasten the withdrawal in order to accommodate Sinhalese nationalism, it may jeopardize the peace efforts in the Tamil region.

India's more successful intervention came in the Maldives. The capital, Male, was attacked on 3 November 1988 by a group of 400 Sri Lankan Tamil mercenaries recruited to overthrow President Maumoon Abdul Gayoom. Indian forces began arriving the same day, relieved the Maldives' small security forces, and three days later captured a freighter carrying the fleeing mercenaries and their hostages.

As the subcontinent's great power, India is looked to for support by the smaller countries, but with trepidation. Therefore, it must exercise its regional role with delicacy and consideration for the interests and sensitivities of its neighbors. India's ability to establish a sound working relationship with Pakistan will be the supreme test of its regional diplomacy. The cordial relationship established between Rajiv Gandhi and Benazir Bhutto at the December 1988 meeting of the South Asian Association for Regional Cooperation has given new hope for improved relations between the two South Asian rivals. 
Vietnamese negotiations until after Vietnamese troops are withdrawn. In fact, however, direct discussions of the issue between the two governments began in January 1989, a hopeful sign for a peaceful settlement in Cambodia. Bangkok also initiated a policy of dialogue with Hanoi and Phnom Penh, sending Foreign Minister Siddhi Savetsila to Vietnam in January and inviting Hun Sen to Thailand.

The Korean Peninsula. The improvement of largepower relationships may also have an effect on the Korean peninsula where the North and South Korean governments have been engaged in sporadic dialogue since 1972. What had appeared to be the start of an improved relationship in 1984 and 1985 was aborted in early 1986 when North Korea cut off Red Cross talks to protest U.S.-South Korean military exercises. In November 1987, a Korean Airline jet disappeared over Burma, and a terrorist captured at the time confessed to being a North Korean agent acting on the order of Kim Jong Il, the son of North Korean President Kim Il Sung. North Korea denied that it was involved.

Despite this incident, both governments have incentives for continuing to issue proposals for North-South reconciliation. North Korea has generally favored highlevel contacts and sweeping plans for confederation, while South Korea proposes step-by-step measures to build confidence. South Korea's Roh Tae Woo sought to seize the diplomatic initiative in July 1988 when he proposed a six-point declaration for improved relations including cultural exchanges, family visits, trade, and diplomatic cooperation. Following the successful summer Olympics, Roh continued to propose initiatives, including an offer to meet Kim Il Sung in Pyongyang. In January 1989, North Korea accepted the South's proposal that the two countries' prime ministers head delegations to hold military and political talks.

The willingness of North Korea to engage in a genuine process of reconciliation with the South has always been suspect. The North, through its allies, has blocked efforts to give both countries membership in the United Nations and opposes cross-recognitionthat is, Japanese and American recognition of North Korea in exchange for Chinese and Soviet recognition of South Korea. These steps, it argues, would solidify the division of Korea. Nevertheless, China and the Soviet Union both have increased nonofficial contacts with the South, and the improving Sino-Soviet relationship may be reducing Kim II Sung's ability to manipulate to his advantage the differences between his two allies.

Significantly, South Korea normalized its relations with Hungary, its first diplomatic partner in the socialist world, and General Secretary Gorbachev, reiterating many of the themes of his 1986 Vladivostok speech in a September 1988 speech at Krasnoyarsk, explicitly called for exchanges with the South. The Soviet Union and South Korea expect to open trade offices in each other's countries in early 1989. Overtures from both China and the Soviet Union toward the South may encourage the North to take a more forthcoming and realistic position on contacts, but a real process of reconciliation may have to await new leadership in Pyongyang.

\section{Conclusions}

In a time of rapid change, the political outlook for the remaining years of the 20th century remains uncertain. Recent developments-the growth of democratic governance at the domestic level and the amelioration of conflict at the international level-are encouraging. However, the challenges of creating and consolidating legitimate political institutions and of establishing a resilient international order are formidable. The Asia-Pacific state system is still in the process of being developed and consolidated. This process will take decades rather than years, for it involves a complicated blending of different Asian cultural and political traditions with introduced Western political concepts. 



\section{CHAPTER TWO}

\section{The Asia-Pacific Economy: Structural Change and Renewed Growth}

I

n 1987 and 1988 strong economic growth returned to the Asia-Pacific region after a downturn in the mid-1980s. The top performers-South Korea and Taiwan-have had growth in excess of 10 percent annually, more than double their growth rates in 1985 . Other countries have rebounded sharply-Singapore from -0.8 percent in 1985 to 8.8 percent in 1987 and 11.1 percent in the first half of 1988, and the Philippines from -3.2 percent in 1985 to 5.1 percent in 1987 to more than 6 percent during the first half of 1988 . China, Hong Kong, and Thailand are continuing to enjoy rapid increases in aggregate and per capita income. Indonesia and Malaysia, whose resource-based economies suffered from the sharp downturn in petroleum prices in 1985 and 1986, are making a slower, but still strong recovery. India, hit hard by drought in 1987, is also recovering.

The economic growth of the late 1980s in the AsiaPacific region partly reflects satisfactory economic performance in the developed countries, which, especially in the wake of the October 1987 stock market turbulence, has been better than expected. In its semiannual World Economic Outlook in September 1988, the International Monetary Fund predicted economic growth in the industrialized countries would reach 3.8 percent in 1988, a full percentage point above its April

Chapter two was prepared by Charles E. Morrison, Coordinator of the International Relations Program, and William E. James, Coordinator of the Development Policy Program, Resource Systems Institute, East-West Center. estimate, and growth would continue at 2.8 percent in these countries in 1989. Japan, the United States, and West Germany have all had higher-than-expected growth.

The recovery in the Asia-Pacific region is also based on the demonstrable ability of outward-oriented AsiaPacific economies to make structural adjustments in tune with changing international economic conditions. In the early 1980s, the rapid growth of the Asia-Pacific region was fueled by the expansion of exports to the U.S. market. Continued access to the U.S. market has remained one source of the new growth in the late 1980s, but a variety of other sources are also important: increased internal investment and consumer demand, reduced regulation and other government interference in the market, diversification of export markets, and increased emphasis in some resource-based countries on labor-intensive manufactured exports in which they have strong competitive advantage.

If the developing countries can continue these efforts, they will have found a viable and balanced growth strategy that will provide a basic thrust for development in the years ahead. The policies of the developed countries are also critical. In 1989 and the beginning of the 1990s, the future of the Asia-Pacific economy hangs on the ability of the United States and Japan to adjust the fundamentals of their economies in a direction that restores their international equilibrium, as well as on the continued adjustments by the developing AsiaPacific countries toward more domestically based growth strategies that minimize international economic frictions. 


\section{The Changing Economic Roles of Japan and the United States}

The United States and Japan play similar regional economic roles in that they are major sources of commercial lending and direct foreign investment. Japan is also a major provider of foreign assistance, while the United States is a secondary source, with its bilateral assistance program in the region focusing principally on the Philippines. In their trade relations with the region, however, the United States and Japan play quite different roles. The United States is the principal market for a wide range of products and has massive trade deficits. Japan is a supplier of goods and remains a major market for fuels and raw materials, but it has large trade surpluses with most of the economies in the region.

These different regional trade positions parallel the two countries' large global imbalances: the United States with a huge current account deficit and Japan with a correspondingly huge surplus. Since these global imbalances are the main threats to the stability of the world economy, their reduction is a priority for both countries and of prime importance to the region. Both countries have taken significant steps toward correcting these imbalances, but their continued ability to sustain these efforts is critical.

\section{The United States}

The relative decline of the United States should not be exaggerated. The U.S. economic role has declined relative to that of Japan in two areas: as a source of investment capital, although it remains a major source of direct foreign investment, and as a source of foreign assistance. Yet the United States is probably the most important single economic actor in the AsiaPacific region for at least two reasons: (1) the health of its economy is vital to the world economy and (2) access to its market is crucial to the development of many of the region's economies.

The United States must reduce two deficits-its external current account and its related domestic budget deficits. Both have declined in absolute terms and, more importantly, in relative terms to the size of the U.S. economy. Aided by continuing growth that enhanced tax revenues, the budget deficit dropped from $\$ 220$ billion in fiscal year 1986 to $\$ 155$ billion in fiscal year 1988 . However, both deficits remain at exceptionally high levels, and future progress is uncertain. Most economists believe that the U.S. fiscal deficit cannot be reduced without increasing taxes, a course the new president, George Bush, has pledged to resist.

The depreciation of the long-overvalued dollar after September 1985 has improved U.S. competitiveness and exports. During most of the 1980s export growth stagnated. U.S. exports stood at $\$ 226$ billion in 1980 and were $\$ 227$ billion in 1986. In 1987, however, they rose sharply to $\$ 252$ billion, buoyed by strength in the manufacturing sector. This trend continued in 1988. The 1987 record merchandise trade deficit of $\$ 171$ billion (f.a.s./c.i.f. basis) is expected to have fallen to about $\$ 135$ billion when final 1988 statistics are available. The prospects for further progress, however, are clouded. Many export industries are operating at close to full capacity, making further dramatic increases in exports more difficult, and American consumers demonstrate a continuing strong appetite for imports.

The Asian media and governments have focused their attention to the U.S. economy on rising protectionist sentiment, especially within the U.S. Congress. The executive branch has counteracted this pressure by adopting a much more aggressive program of bargaining for increased export opportunities. Both pushes-congressional protectionism and executive branch export expansion promotion-are directed toward the AsiaPacific region, which has a huge trade surplus with the United States. Of the six economies in the world with the largest surpluses with the United States in 1987, four were located in the Asia-Pacific region-Japan, Taiwan, South Korea, and Hong Kong. With the exception of Japan, imports from the region continue to grow. U.S. imports from the four newly industrialized economies (NIEs) jumped 17 percent in 1986 and another 25 percent in 1987. The U.S. deficit with the NIEs quintupled from $\$ 7.0$ billion in 1981 to $\$ 37.7$ billion in 1987 . The United States also has deficits with the four major resource-rich ASEAN countries (the ASEAN-4 are Indonesia, Malaysia, the Philippines, and Thailand). In the entire region the United States has a substantial trade surplus only with Australia (at $\$ 2.2$ billion in 1987) and small surpluses with Pakistan, Brunei, Nepal, and several Pacific island nations.

The sustained growth of U.S. imports from Asia reflects the relative openness of the U.S. market, despite protectionist threats. Asia was a principal target of two legislative proposals that could have constrained access to the U.S. market: the "Jenkins bill" would have applied drastic limits on textile, apparel, and footwear imports, and the "Gephardt amendment" would have called for retaliation against countries that do not correct "excessive" trade surpluses with the United States. The Jenkins bill was vetoed by President Reagan in 1986, and the Gephardt amendment was dropped from the Omnibus Trade and Competitiveness Act of 1988 by a Senate-House conference committee.

As it slowly made its way through the U.S. Congress, the Omnibus Trade and Competitiveness Act was the principal vehicle of struggle over U.S. trade policy. This new law establishes the basic framework for U.S. trade 
policy for some years to come. In its final version, it was not a radical break from the past. It includes many provisions that strengthen the U.S. commitment to an open world trading system including a grant of broad negotiating authority to the president to make tariff and nontariff adjustments as part of the Uruguay Round of GATT negotiations, the adoption of the new Harmonized Tariff Classification System, and the expansion of the domestic trade adjustment assistance programs. Other provisions can be used to protect domestic interests. This includes the "Super 301" authority, which is intended to strengthen U.S. ability to retaliate against certain foreign trade practices, and the elimination of the need to show injury in cases of alleged patent infringements. The future effect of the new law, however, depends on how it is implemented by the executive branch. The law may make it politically more difficult for the president to resist some protectionist pressures, but it preserves the basic right of presidential discretion in adopting trade sanctions or providing import relief.

If the United States succeeds in its economic objectives, it must achieve a positive change in its current account of about $\$ 150$ billion. Much of the burden of this adjustment will be on Japan and the NIEs, which together have a trade surplus with the United States of almost $\$ 100$ billion. A key longer-term question for these countries is whether they will undertake the kinds of domestic policy and market opening actions that will facilitate the American adjustment.

\section{Japan}

Japan's changing economic role has been an important stimulus for growth in the rest of the Asia-Pacific region in 1987 and 1988. With expectations of reduced import market growth in the United States, developing Asian countries increasingly look toward Japan as an alternative export market and source of capital imports. However, Japanese government austerity budgets restrained domestic consumption and investment and depressed import demand during much of the 1980s. Until the finance ministers of the major economic powers sent the yen on an upward course with the September 1985 Plaza Agreement, the undervaluation of the yen in the early 1980s made Japanese exports highly competitive and reduced the competitiveness of imported goods into Japan. Reduced consumption of fuels and raw materials and lower prices of these imports contributed to the fall of Japanese merchandise imports, on a customs clearance basis, from $\$ 140.5$ billion to $\$ 126.4$ billion between 1980 and 1986 . With imports constituting less than 10 percent of the gross national product (GNP) by 1986, Japan had one of the lowest import dependency ratios in the developed world.
Meanwhile, exports soared, and Japan experienced growing trade surpluses, jumping from a $\$ 10.7$ billion deficit in 1980 to an $\$ 82.7$ billion surplus in 1986.

Japan's budget austerity and export-oriented growth were heavily criticized abroad and increasingly at home, leading former Prime Minister Yasuhiro Nakasone in 1985 to create a private commission, headed by former Bank of Japan governor Haruo Maekawa, to reexamine Japan's economic directions and priorities. The Maekawa Commission, in its first report of April 1986, called for a historic transformation of the Japanese economy from an export and external demand-oriented economy to an import and domestic demand-led one. Although the report's conclusions were domestically controversial, it succeeded in establishing a basic economic goal against which policy and performance could be measured.

By 1988 , the transformation of the Japanese economy seemed well under way, propelled by exchange rate appreciation and some shift in macroeconomic policies. The $\mathbf{4 0}$ percent increase in the dollar value of the yen in the two years after September 1985 initially caused a "high yen" recession. Marginally competitive Japanese companies were driven out of business; economic growth dropped to 2.5 percent in 1986 , the lowest rate in 12 years; and the unemployment rate steadily climbed to a post-Second World War high of 3 percent by mid-1987.

The recession, however, was short-lived, as the Japanese economy adjusted successfully to the highervalued yen and the government finally broke with its strict fiscal austerity program in fiscal year 1987 (beginning 1 April 1987), pumping $¥ 6$ trillion (about $\$ 47$ billion) into the economy, $¥ 5$ trillion in public investment financed from the sales of stocks of privatized government corporations, and $¥ 1$ trillion in reduced taxes to stimulate demand. Domestic demand picked up, contributing 5 percent to GNP in 1987, while the contribution of external demand was -0.7 percent. Public works activity was at its highest level in 9 years, and housing had its best year in 24 years. The service industry boomed, taking up the slack as jobs in manufacturing industries decreased. As imports grew, the trade and current account balances in 1987 began to drop. The strong turnaround in the strength of Japan's domestic economy and its ability to reduce its trade deficit won considerable international praise.

The shifts in Japan's economic directions had important implications for the developing Asia-Pacific economies. In order to maintain their competitiveness, Japanese companies sought to transfer more laborintensive manufacturing production processes overseas; they increased investment in the NIEs and ASEAN countries. According to the Japanese finance ministry, reported Japanese investments in Thailand increased 
from $\$ 48$ million in fiscal year 1985 to $\$ 250$ million in fiscal year 1987; in the same period in South Korea they expanded from \$134 million to \$647 million; and in Hong Kong, they went from $\$ 131$ million to $\$ 1.07$ billion. Imports, especially from the NIEs, grew dramatically, and most of these new imports were manufactured goods. By late 1988, manufactured goods accounted for more than half of Japan's imports compared to just a third in 1985.

Despite the new confidence in Japan of the country's ability to make the necessary international adjustments and achieve stable domestic growth, Japan continues to face a longer-term challenge in reducing its current account surplus of almost $\$ 79$ billion in 1988 . The course of domestic demand-led expansion and more rapid growth of imports over exports must be sustained over several years. Some economists argue that Japan must consider more fundamental economic reforms to sustain domestic expansion, especially in two areas.

First, it is argued that Japan should make a stronger effort to open its domestic market, particularly to reduce nontariff barriers that limit the absorption of imports. Recent attention has been focused especially on the distribution sector in which national laws and administrative regulations restrict the growth of larger supermarkets and department stores.

Second, there should be increased attention to the means of reducing the gap between Japan's high rate of savings and its much lower level of investment. One factor in forcing excess savings, which is equivalent to the current account surplus, lies in inefficient land-use policies that cause very high housing prices. The second Maekawa Commission report suggested a number of steps to address this problem, including preferential tax treatment for home purchases, elimination of preferential tax treatment of agricultural land in urban areas to encourage its conversion into residential use, and rezoning to increase the land available for housing.

Without continued efforts to expand domestic demand and reduce formal and informal barriers to imports, it is feared that the fall in Japan's external surpluses may slow and be reversed. This would be reflected in a more-or-less corresponding external deficit in the United States, contributing to increased upward pressure on the yen, unease in the financial markets, and potential recession.

\section{The Newly Industrialized Economies}

The NIEs are among the wórld's most export-dependent economies, with exports ranging from 45 percent of
GNP in South Korea's case to 137 percent of GNP for Singapore. Consequently, although the size of their combined economies is less than a quarter that of Japan's, collectively they are involved in about the same amount of external trade. This trade, in the cases of Taiwan and South Korea, is highly skewed toward exports, leading to massive surpluses in relation to the size of their economies. Taiwan's $\$ 18$ billion current account surplus in 1987 was 19 percent of GNP, while South Korea's $\$ 10$ billion surplus was more than 8 percent of GNP. In comparison, Japan's current account surplus is about 3 percent of GNP. The four NIEs' bilateral trade surpluses with the United States of $\$ 37.7$ billion in 1987 was more than the $\$ 30.2$ billion U.S. deficit with the European Economic Community (EEC). Since the NIEs' currencies did not appreciate as much against the dollar as the yen did, they have gained competitiveness in the U.S. market, with their imports rising from 57 percent of Japanese imports in 1985 to 74 percent in mid-1988.

These surpluses have focused international attention on the NIEs as never before. They are now recognized as a major part of the international economy and are viewed, because of their surpluses, as a problem in reestablishing global equilibrium. A number of events in 1988 reflected the growing economic role of the NIEs.

- In January 1988, the United States announced it would end preferential tariff treatment to the NIEs under its Generalized System of Preferences (GSP) for developing countries in January 1989. Other advanced countries are likely to pursue the same course, although Japan, which has a surplus in its trade with the NIEs, has pledged to continue preferential trade treatment for the time being.

- The NIEs received heavy criticism from the finance ministers of the 24-nation Organization for Economic Cooperation and Development (OECD) at their annual meeting in May 1988. Great Britain's Chancellor of the Exchequer Nigel Lawson, for example, commented that the "very controlled and unopen" nature of the South Korean and Taiwanese economies cause their trade surpluses.

- The June 1988 Group of Seven Toronto Summit of the seven major industrialized countries noted the growing importance of the NIEs and encouraged them to increase the value of their currencies and diversify their economies. The communiqué at the end of the summit referred to the need of the NIEs to assume greater international responsibilities and called for improved dialogue and cooperation between the industrialized and newly industrialized 


\section{Box 2.1 \\ The Growth of Intra-Asian Trade}

The past few years have witnessed strong growth in trade between Asian countries-both between developed and developing countries in the region and among the developing countries themselves. It is anticipated that in 1989 or 1990 trade between countries on the western rim of the Pacific will exceed trans-Pacific trade. Much of this growth reflects the recent sharp increase in manufactured imports from the newly industrialized economies (NIEs) to Japan. Trade between the NIEs and the ASEAN countries is also growing, and the growth of trade with China, following its open-door policies, has been another factor.

Although the developing countries have generally directed their efforts toward increasing export opportunities in the developed countries-their major markets -there are significant opportunities to benefit from by increased trade between the developing countries. The high tariff and nontariff barriers maintained by many developing countries, however, have inhibited the growth of such trade. The ASEAN preferential trade scheme, although quite limited, is one of the few systematic programs to increase trade among the developing countries.

Asia is the only major region where intraregional trade between developing countries is increasing. This is a positive trend, which helps Asian developing countries diversify their export markets and sources of supply.

\section{Box Figure 2.1 Intraregional Trade among Developing Countries: 1975-87 (\% of total exports)}

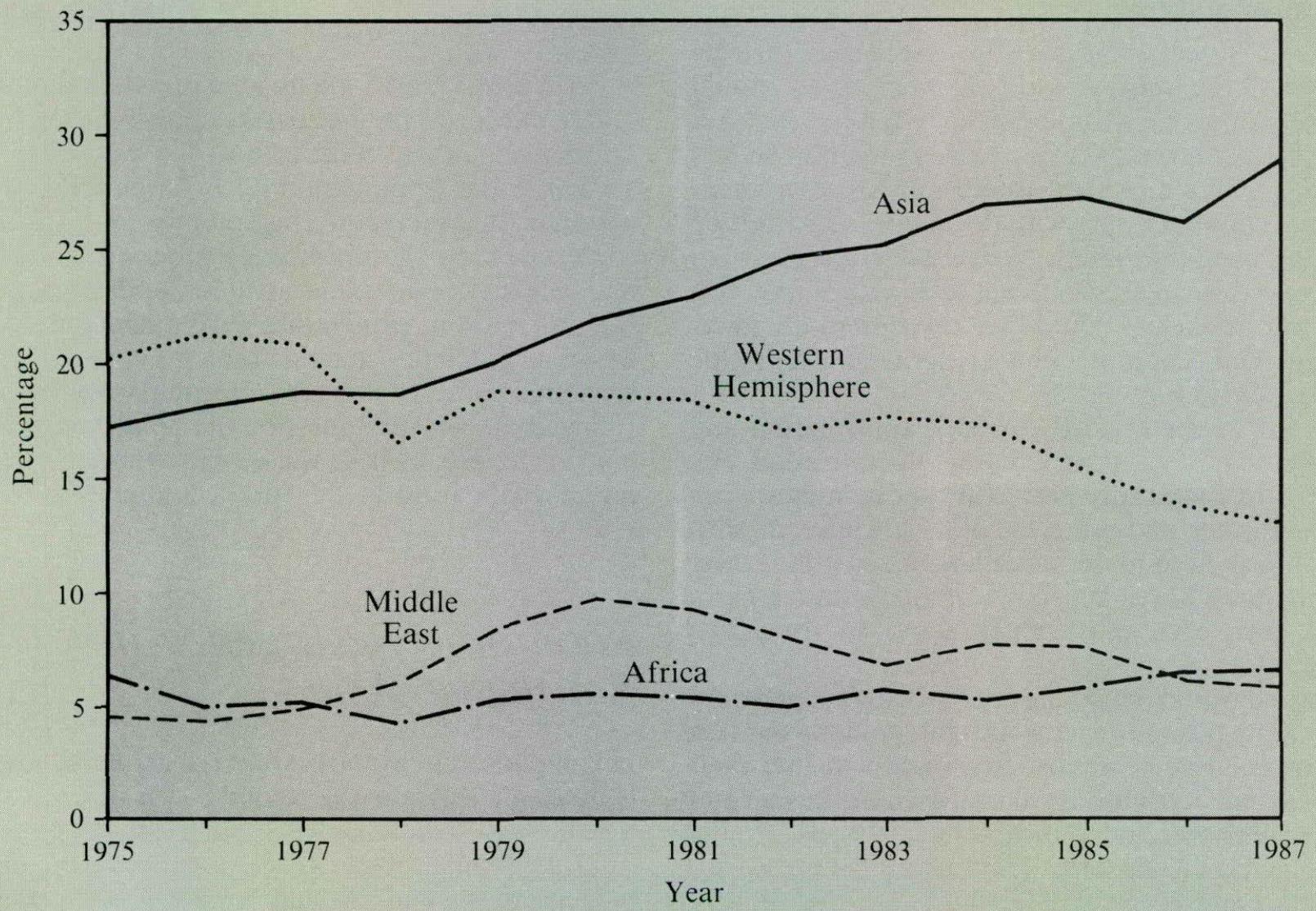

Note:

Regional groupings are according to International Monetary Fund and include all Asian and Pacific countries.

Sources: International Monetary Fund, Direction of Trade Statistics, Yearbooks 1982, 1983, 1984, 1985, 1986, 1987, and 1988. 
economies. The first such dialogue occurred on an informal basis under OECD auspices in January 1989.

- Yasuhiro Nakasone, Japan's former prime minister, in March 1988 and former U.S. Secretary of State George Shultz in July proposed the creation of an intergovernmental consultative organization, modeled on the OECD, to monitor the region's economies and discuss economic policy issues. Such an organization would include the present as well as potential NIEs, such as Thailand, Malaysia, Indonesia, and the Philippines.

- In October 1988, in a report required by the new U.S. trade act, the U.S. Department of Treasury accused Taiwan and South Korea of manipulating currency exchange rates to keep their currencies artificially low compared to the dollar, undermining U.S. efforts to improve its trade balances.

The NIEs, especially Taiwan and South Korea, face two sets of critical questions. The first regards their relations with the outside world: To what extent should they accommodate outside pressures for currency appreciation and increased market access and how should they engage in a more constructive dialogue on international economic issues with the major industrialized countries? And the other is a related internal question: In the face of increased external resistance to their exports, what policies should they take internally to restructure their economies and strengthen the domestic contribution to growth?

The NIEs have resisted currency appreciation and have begrudgingly accepted market liberalization. Politically and financially powerful export interests oppose the former, and protected domestic interests with new political clout under more liberalized political regimes in South Korea and Taiwan fight the latter. Farm groups have been particularly active in these two economies.

Hong Kong and Singapore rejected external pressures to appreciate their currencies outright, pointing out that they practice free or almost free trade and that their global current accounts are in equilibrium. Taiwan and South Korea have allowed their currencies to rise-more than 30 percent against the U.S. dollar for the New Taiwan dollar and 20 percent for the South Korean won since the Plaza accord-but this has not satisfied the Americans and Europeans. Taiwanese and South Korean officials point out that because of their economies' very high rates of export dependence, too rapid an appreciation of their currencies would cause much more serious dislocations than occurred in Japan during the 1986 high-yen recession. Another fear is that their competitiveness may be undermined by higher wage rates. All NIEs face some threat of labor unrest, although this has been most prominent in South Korea, where a series of strikes has led to wage increases of as much as 20 percent in some manufacturing industries. The South Koreans also argue that they should be allowed to have a current account surplus for a few years until they are able to further reduce their $\$ 33$ billion foreign debt.

In February 1988, Taiwan cut tariffs on 3,500 products by an average rate of 50 percent. This, and a controversial effort to purchase gold from the United States, boosted imports almost 20 percent during 1988 and reduced the trade surplus substantially. Taiwan plans further tariff reductions in 1989. South Korea lowered tariffs on 266 items in 1987 and 435 items in 1988. It permitted entry of foreign tobacco products but resisted American pressure on other sensitive agricultural items. Exports to the NIEs from the United States, the group's principal deficit nation, are increasing. In 1987 exports from the United States to Taiwan expanded by 38 percent and about 30 percent to Hong Kong and South Korea.

Perhaps the most fundamental reassessment of economic directions has occurred in South Korea, where, on 25 April 1988, President Roh Tae Woo established a Presidential Commission on Economic Restructuring. In an interim report, this commission recommended accelerating the opening of domestic markets by reducing tariffs on manufactured goods and improving distribution, eliminating government subsidies to declining industries, and diffusing the concentration of economic power by strengthening antimonopoly action. It linked the sensitive question of opening agricultural markets to restructuring the agricultural sector, including diversification of the rural economy.

\section{Economic Resurgence in Southeast Asia}

In comparison to the NIEs, rapid structural adjustment is more difficult for the resource-rich ASEAN-4 and South Asian economies with their much larger agricultural and primary product sectors, entrenched economic interest groups, and generally weaker government structures. There is a sharp contrast between these two groups, however. The ASEAN-4 are much more externally oriented, whereas foreign trade and investment play a relatively limited role in the South Asian economies except for Sri Lanka.

In the mid-1980s, the ASEAN-4 suffered heavily from the decline in commodity prices. This stimulated 
government efforts to diversify their economies, increase efficiency through the deregulation of the private sector and privatization, and increase foreign investment. These efforts have begun to show results. In 1988 Thailand's real economic growth rate of more than 10 percent in the first three quarters led the economic resurgence of the ASEAN-4. Malaysian and Philippine growth rates were in the 6 to 8 percent range, and the prospects for Indonesia improved with the growth rate in 1988 expected to reach about 5 percent.

Booming exports have been the main source of new growth. The prices of rubber, sugar, palm oil, tin, copper, and other major primary exports increased in 1988 compared to 1987 , although petroleum prices remained low. Manufactured exports also grew strongly. The competitiveness of manufactured exports from the ASEAN -4 has increased both as a result of the appreciation of the yen, won, and New Taiwan dollar and improved incentives for export-oriented producers.

Domestic demand also strengthened in the past year. Investment expenditures as well as private consumption rose sharply. Despite this, inflation rates have remained very low in Thailand and Malaysia and are contained within single-digit figures in Indonesia and the Philippines.

The dramatic acceleration of economic growth in Thailand, the recovery of a relatively prosperous Malaysia, the deepening expansion of the Philippine recovery, and Indonesia's success at stimulating nontraditional exports to compensate for shortfalls in petroleum earnings all contributed to a mood of confidence and optimism.

\section{The Next NIE}

Renewed economic growth in the ASEAN-4 has stimulated speculation on the emergence of the group as NIEs and some friendly rivalry between Thailand and Malaysia over which of the two is likely to be the first new NIE. Thailand's per capita income of around $\$ 900$ is only about a third that of South Korea, but Thailand demonstrates many of the characteristics of an emerging industrializing nation. The country enjoys relatively high savings and investment rates and a rapidly growing industrial sector that contributes more to gross domestic product than the traditionally dominant agricultural sector.

Moreover, the Thai economy has shown a remarkable ability to make needed structural adjustments in recent years. In comparison to the NIEs, it has a diversified pattern of export growth based on the export of agricultural and manufactured goods such as textiles, shoes, toys, jewelry, and semiconductor chips. Its markets are more diverse than those of most of the NIEs, which have concentrated heavily on the United States.
Thailand has also been a major beneficiary of the Japanese push for overseas investments since the yen appreciated. The rapid growth of investment and trade, however, has placed great pressure on Thailand's port facilities, roads and railways, water and electricity supplies, communications systems, and other physical infrastructure. The public education system has been oriented toward training civil servants rather than engineers and business managers. Some economists believe that without tremendous investments in infrastructure and manpower, Thailand's rapid growth cannot be sustained. Other formidable challenges include environmental degradation and growing regional income disparities between Bangkok and the less-developed parts of the country.

Malaysia, with about twice the per capita income of Thailand, hopes to become an NIE by 1995. In the early 1980s, Malaysia appeared to be the best contender for NIE status among the ASEAN-4, but with an economy that was still highly dependent on commodity exports, Malaysia was much more vulnerable than Thailand to the fall in commodity prices. Despite an expansion in the physical volume of its exports between 1984 and 1986, export earnings fell. The average annual growth rate of gross domestic product dropped sharply from 6.5 percent for the period $1981-84$ to -1 percent in 1985 and 1.8 percent in 1986 before recovering some buoyancy. Other constraints on aggregate growth include economic policies designed to achieve the political goal of improving the income share of the Malay part of the population and an overly ambitious effort to develop heavy industries without a sufficient domestic market base to support them.

The Malaysian government responded to the economic recession of 1985-86 with a new policy emphasis on the development of export-oriented manufacturing industries and increased emphasis on direct foreign investment. A new investment act in 1986 allowed foreigners to completely own manufacturing firms that export at least 80 percent of their production, and liberalized the hiring of foreign staff for senior positions. Although Malaysia has relatively high wages compared to the other ASEAN-4, it has staged a successful recovery. Malaysia was able to take advantage of strong demand in the developed countries, especially for semiconductor components, of which Malaysia is the world's third largest producer and largest exporter. Led by gains in electronics, textiles, and rubber-based products, the manufacturing sector grew by 12 percent in 1987, replacing agriculture as the largest contributor to the Malaysian gross national product. Approved foreign direct investment in 1987 was more than twice the level of 1983 and 1984.

The expansion of the Thai and Malaysian economies, thus, qualifies both as likely candidates to achieve NIE 
status during the 1990 s. However, continuation of their growth depends on continued demand for their exports. Slower growth in the developed world, increased protectionism, or another reversal of commodity prices could substantially delay the economic progress of these economies.

\section{Recovery in the Philippines and Indonesia}

The most dramatic turnabout in economic growth over the past two years in Southeast Asia has occurred in the Philippines. Per capita incomes plunged between 1981 and 1986. Despite growth of real gross domestic product (GDP) of 5.5 percent in 1987 and almost 7 percent in 1988, per capita incomes remain below where they stood a decade ago. Unemployment and underemployment remain severe as the labor force and population continue to grow at more than 2.5 percent per year. The economic recovery was initially led by the resurgence of consumption expenditures fueled by government pump priming following successful debtrescheduling discussions in 1986 . However, by 1988 exports and private investment in plant and equipment became stronger as the boom in consumer spending and construction continued.

The Philippine economy has serious structural problems that will require sustained and determined efforts to correct. Government resources are inadequate to simultaneously service debt and provide basic economic services such as maintenance of infrastructure, health care, and education, let alone build new infrastructure, implement agrarian reform, and effectively deal with a serious insurgency and social and political unrest. Efforts are under way to improve tax administration and attract increased flows of foreign financial resources. Private savings and investment will be crucial to future growth. To sustain growth not only must greater resources be devoted to investment, but the efficiency of the investments must be raised substantially. Exportoriented manufacturing of labor-intensive goods that require locally available materials has been identified as an area of high priority. Yet, despite the urgency of achieving more employment and export earnings from manufacturing, the government continues to promote a large number of capital-intensive industries such as steel, automobile assembly, and chemicals. The development of the economy in a manner that not only enhances employment and the incomes of the poor, especially in rural areas, but does so in a sustainable way presents formidable challenges.

The Indonesian economy was hit hardest by the commodity slump of the $1980 \mathrm{~s}$. The collapse of oil prices in 1986 cut dollar export earnings sharply and seriously eroded government tax revenues. Moreover, the dollar's decline compounded Indonesia's immediate econom- ic difficulties, as over 60 percent of its external debt was denominated in strong currencies, particularly the yen.

Indonesia adopted a number of reforms and undertook other measures to adjust. These are proving successful. Despite a continued slump in the large petroleum sector and difficulties in sustaining agricultural growth, the economy has begun to rebound. Manufacturing activities and investment have grown, and exports of manufactured products have expanded quickly enough to raise total exports. The improvement in growth performance was achieved while the balance of payments was improving. The large debt-servicing obligations require the government to maintain a relatively cautious fiscal policy.

Renewed attention to agricultural diversification and promotion of industrial activities that generate employment will be of foremost importance along with sustaining the momentum in boosting nontraditional exports. Indonesia is actively seeking foreign investors in new economic activities designed to contribute to overall national development as well. Growth prospects should continue to improve as policies become more open and market-oriented. The de-emphasis on expensive public sector projects is leading to more reliance on private initiative and competition to spur productivity growth.

\section{South Asia: Improving Conditions for Growth}

The growth performance of South Asian economies, in contrast to the NIEs and the ASEAN-4, has improved in the 1980s compared to the previous decade. India was able to raise its economic growth rate substantially by adopting reforms that encourage greater openness and competition in the domestic economy. In 1987 the Indian economy weathered the most severe drought since independence and rebounded strongly in 1988. Growth of exports of manufactured goods from India has been impressive since 1986. Devaluation of the rupee and aggressive measures to cut red tape and improve financing and infrastructure for exports have stimulated exports. The 25 percent rise in total exports in 1988 over 1987 will ease India's debt-servicing burden. The government hopes to attract more foreign investment including investment in leading manufacturing sectors.

The outlook for the future is clouded by difficulties in finding sufficient government revenues to finance budgetary outlays in a noninflationary manner. Despite India's relatively high saving rate, there has been a seri- 
ous erosion in government savings. Current revenues are barely enough to cover current expenditures. Hence, public investments increasingly depend on external or domestic borrowing. Rising government borrowing could deny private investors access to funds, making it more difficult to improve India's competitiveness.

Pakistan's economic growth rates have been among the highest in Asia in the 1980s. The high growth continued in 1987 and 1988, averaging 7 percent or more. Per capita gains have been less impressive as high population growth has offset them. There has been substantial structural change in the Pakistan economy; the industrial sector's contribution to gross domestic product has recently surpassed the contribution of the agricultural sector. However, despite large production gains, there have been lags in employment generation, improved income distribution, and human resource development.

Although Pakistan appears to be moving rapidly away from the status of a low-income developing country toward that of a middle-income developing country, much remains to be done in upgrading living standards, particularly in rural areas. The low taxcollecting capacity of the government is a major obstacle to the expansion of such basic services as primary education, sanitation, water supply, and health care. Large budgetary outlays for interest payments on government debt and defense as well as subsidies to unprofitable public enterprises have severely limited the government's flexibility. The ability of the new government to redirect expenditures will partly depend on whether it is able to reduce subsidies to public enterprises. Efforts to improve enterprise efficiency through privatization, by improving management, and by allowing enterprises greater autonomy in pricing and other decisions are all being considered.

These problems are fairly general in South Asia. What Pakistan's experience indicates is that aggregate growth by itself may not be enough to overcome the deep-seated problems of poverty. A pattern of growth emphasizing employment and participation of the rural poor would seem to be essential for meaningful reduction in poverty in most of South Asia.

Sri Lanka, which had gone farthest in the direction of market-oriented reforms in South Asia, has sustained economic growth of about 5 percent per year in the 1980s. Recent growth has been held back by political unrest that verges on civil war. Tourism, which was formerly one of the leading sectors earning foreign exchange, has been severely affected by the violence. The future outlook is clouded, and full recovery of the economy will depend on a more peaceful domestic environment.

In Bangladesh and Nepal growth rates have barely kept pace with population increases. Per capita incomes remain among the lowest in Asia. Natural disasters in 1987 and 1988 had an adverse impact on agriculture, the most important economic sector in both economies. This has set back overall economic growth. Bangladesh has been successful at developing some nontraditional exports including garments, fresh and frozen shrimp, and some light manufactured goods. However, the impact on aggregate growth of these has been limited. In both Nepal and Bangladesh growth prospects largely hinge on raising productivity in small-holder agriculture. What is needed to accomplish this is already wellknown-improved irrigation and flood control works, better farm-to-market transport infrastructure, distribution of improved seeds and fertilizer, broader outreach of extension and educational programs and information, and adequate incentives. Progress has been made in spreading the means of increasing farm output among small holders, despite the setbacks from the natural disasters. Without sustained gains in smallholder incomes, it will be very difficult to raise overall economic growth in the lower-income countries of South Asia.

The preconditions for the type of economic transformation that has occurred in East Asia and that seems to be under way in Southeast Asia have yet to be firmly established in much of South Asia. Some recent successes suggest that South Asia is ready to achieve the dynamism of the rest of the region. The ability of governments and the private sector to effectively respond to natural disasters and avoid widespread famine and disease outbreaks is notable. The upturn in agricultural and industrial production in the 1980 s, particularly in India and Pakistan, has been impressive if not spectacular. The recent expansion of manufactured and total exports in almost all South Asian economies indicates trade will play a more significant role than in the past. This will be important if South Asia is to expand its ties with its dynamic neighbors to the east.

\section{Conclusion}

As the 1980s end, the Asia-Pacific region seems wellpoised to continue its economic growth at rates substantially above the world average. In most of the region, the basic prerequisites for growth are present. These include natural resources or access to resource supplies, a capacity to accumulate capital through savings and borrowing and to invest it productively, a stable political climate conducive to economic activity, and an increasingly productive labor force as levels of basic education improve and specialized skills are assimilated. Most impressive, perhaps, has been the capacity shown by the private sector and policymakers to ad- 
just to external challenges and to exploit new opportunities.

The process of economic modernization in Western Europe and North America required decades. Japan became a rich, advanced country in a shorter period, but one that nonetheless required more than a century if the 1868 Meiji Restoration is regarded as an appropriate point of departure. The NIEs, the ASEAN-4, and even the South Asian economies are engaged in an even faster process of catch-up development. Current tech- nologies and the relatively free flow of goods and capital give impetus to faster development, but the capacity of individuals to adjust and of societies to develop the necessary institutional infrastructure have changed less rapidly. Thus, if past performance and current conditions encourage optimism about continued rapid growth in most of the Asia-Pacific region, it should also be remembered that the structural transformation from lesser-developed to advanced societies is a longer-term, uneven, and often tension-laden process. 


\title{
PART II
}

\section{Special Report}

\author{
China \\ in the \\ Reform Era
}


China

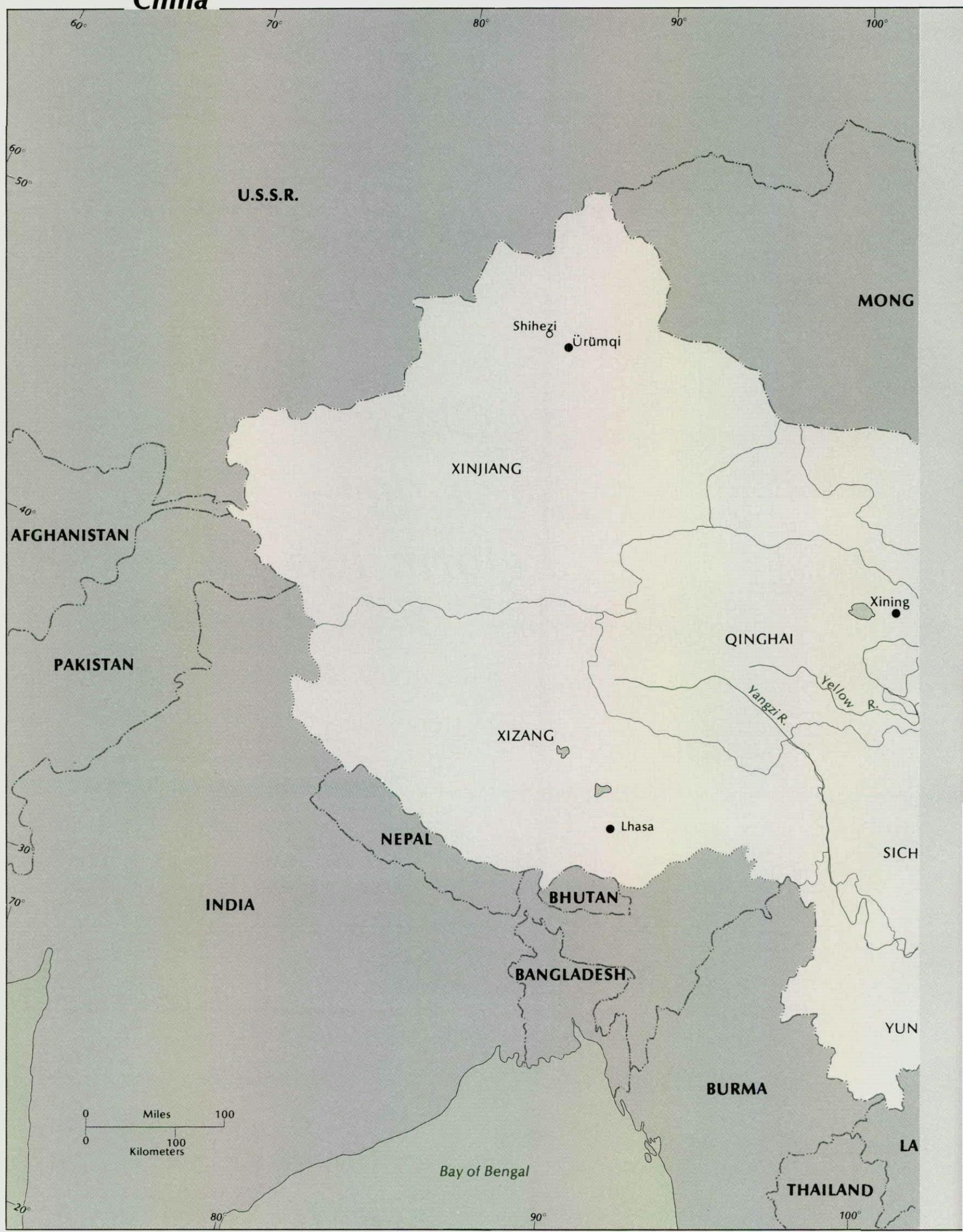




\section{CHAPTER THREE}

\section{The People's Republic of China: A Historical Introduction}

\begin{abstract}
$A$ dard of living than most of the world's population. The historic teachings and customs of the Chinese gave rise to a powerful central government and a bureaucracy that proved able to govern a greater area and larger population for a longer period than any other system in world history. The economic system was based on the right to own property and make written contracts. Peasants, craftsmen, and merchants practiced specialization in production and trade, made possible by the use of money in markets tied together in an extensive network of villages, market towns, and metropolitan centers throughout China. Chinese cultural and technical accomplishments were most impressive. In fact, when Marco Polo observed all this during the reign of the Mongols in the 14th century and reported it to Europe after his visit, he was imprisoned as either a fraud or a madman.

Despite this glorious past, China's more recent history is much less auspicious. Rapid population growth and the problems of sheer size taxed and finally overwhelmed the capacity of the traditional Chinese economic and political system. In Europe the Scientific Revolution and the Reformation helped shed the shack-
\end{abstract}

Chapter three was prepared by Robert $F$. Dernberger, Research Associate, East-West Center, and Professor of Economics at the University of Michigan. les of feudalism and launch the Industrial Revolution. When the end of the Napoleonic Wars freed the nations of Europe to turn their attention overseas, their attempts to "carve up" China precipitated the collapse of the Chinese empire and imperial system. Reformers at the end of the 19th century repeatedly failed to stem the decay of the traditional imperial system, and the revolutionaries of the early 20 th century failed to create a viable new government. When the Nationalist-led armies under Chiang Kai-shek finally created a central government recognized by the Western powers at the end of the 1920s, they directly controlled only about half the country's area.

Following the First World War, the German sphere of influence in Shandong was transferred to Japan. The frustration with China's failure to recover control of its territory generated widespread student and worker anti-imperialist and nationalist movements. Out of these movements came the birth of the Chinese Communist Party (CCP) in the early 1920s. The Nationalist Party and government were unable to defeat the Communists in the civil war before the Second World War. During the Second World War, the Communists gained strength but they still startled their enemies and friends (and probably themselves) with the ease with which they won control of the mainland at the end of the 1940s. On I October 1949, at the Gate of Heavenly Peace in Tian'anmen Square in Beijing, Mao Zedong announced the creation of the People's Republic of China.

It would, of course, be some time before the newly established government could hope to realize its promise 
of making China a major world power whose people enjoy a high standard of living. In 1950, China was only one of many countries in the Asia-Pacific region that were searching for a new and important identity. In the almost four decades since 1950, the Chinese have seen their efforts to restore China to a position of power and wealth, largely in isolation from developments elsewhere in the Asia-Pacific region, fall far short of their intended objective. However, the death of Mao and the reemergence of Deng Xiaoping and his followers have given

\section{Box 3.1 China in the 20th Century}

Revolution, 10 October 1911. Nineteenth century Western imperialism in China convinced many Chinese of the need for major reforms. After 1905 Sun Yat-sen led military officers and students in advocating the overthrow of the Manchu Qing emperor. An uprising on 10 October 1911 by Hubei Army troops quickly spread to two dozen other areas, and by early December most of China's provinces declared their independence from the Qing court. In February 1912, the Qing court abdicated and China was declared a republic, entering into a long period of warlordism.

The May 4th Movement, 1919. Patriotic students in Beijing protested the Versailles Peace Conference decision that would allow Japan to retain defeated German rights and possessions in Shandong province after the First World War. The protests spread throughout major cities in China and moved China onto new revolutionary paths led by Sun Yat-sen's Kuomintang (the KMT or the Chinese Nationalist Party) and the Chinese Communist Party (CCP).

The Long March, 1934-35. After Sun Yatsen's death in 1925, one of his protégés, Chiang Kai-shek, commander of the Nationalist army, launched the Northern Expedition in July 1926 to smash the warlords and unify China. During spring 1927, the Kuomintang began unifying its political base, purged itself of the communist program, and set up its base with Nanjing as the capital. An uprising of Communist troops at Nanchang on 1 August 1927 began an open civil war between the two parties. After a series of anti-communist "extermination campaigns" led by Chiang Kai-shek between 1931 and 1934, the CCP fled its base in Jiangxi province in October 1934 and began a oneyear, 6,000-mile "Long March" to Shanxi province under the leadership of Mao Zedong. For 10 years a Communist territorial base in the northwest gave Mao the opportunity to solidify the leadership.

China's Civil War, 1945-49. An all-out war between Japan and China, which lasted until 1945, erupted after a minor clash between troops near Beijing on 7 July 1937. During this war, the CCP and KMT nominally formed a "united front"' to oppose the invaders, while continuing their struggle for power. After the end of the Second World War and the defeat of Japan in 1945, the civil war between the Nationalists and the Communists resumed in full force.
The People's Republic of China, 1 October 1949. On I October 1949, the Chinese Communist Party and leader Mao Zedong proclaimed the People's Republic of China. The Nationalists, headed by Chiang Kai-shek, set up government in Taipei, Taiwan, on 8 December 1949.

The Great Leap Forward, 1958. At the beginning of 1958, the Chinese leadership launched a strategy to develop the industrial and rural agricultural sectors by using China's large reservoir of manpower. The all-out growth effort led to massive errors resulting in serious economic dislocation.

The Sino-Soviet Split, 1960. Ten years after the 1950 Sino-Soviet Treaty of Friendship, Alliance and Mutual Assistance, the Soviets withdrew their technical aid and experts from China. The break was further exacerbated by the Sino-Indian border dispute in 1962 when the Soviets supported Indian boundary claims, and later in 1969 when the Soviets and the Chinese clashed in a series of border disputes.

The Great Proletarian Cultural Revolution, 1966-76. Mao Zedong launched a mass movement in 1966 directed against CCP members in authority that had taken the "capitalist road." Mao used middle-school and university students, known as the Red Guards, to carry out the movement. Although the Red Guards were repressed in 1969, the movement continued until 1976 and ended that year with the deaths of Premier Zhou Enlai and Mao and the arrest of the Gang of Four, including Mao's wife Jiang Qing.

Third Plenum of the 11th CCP Central Committee, December 1978. The Third Plenum set in motion a series of reforms that brought about fundamental change to the political and economic order of China and established Deng Xiaoping as China's paramount leader.

Normalization of Sino-American Relations, 1 January 1979. In February 1972, U.S. President Richard Nixon traveled to China where he signed with Premier Zhou Enlai the Shanghai Communiqué, ending 22 years of estranged relations between the two countries. The normalization process was completed in January 1979 when the United States recognized the People's Republic of China as the sole legal government of China and notified Taiwan that it was terminating diplomatic relations and the mutual defense treaty with the KMT government. 
the Chinese a renewed sense of hope for realizing China's destiny.

Other countries in the Asia-Pacific region are also pursuing social, political, and economic reforms. Some of the problems these countries are trying to solve as well as some of the reforms being adopted to solve them are similar to those faced by the Chinese. However, the scope of the Chinese reform program makes it one of the most distinctive attempts in world history. China's desire at the end of the 1970s to open up and change its institutions and policies so that it could play a much more significant role in both the Asia-Pacific region and the world has contributed and can continue to contribute much to the success of the Asia-Pacific region. Thus, the chapters that follow should shed light not only on developments in China but also on the prospects for China's contributions to the process of economic growth, political development, and growing interdependence taking place throughout the AsiaPacific region.

\section{The People's Republic of China: The Initial Years}

In the four decades since the creation of the People's Republic the Chinese have been engaged in one of those rare and unique episodes in history: a sweeping political, economic, and social revolution. This revolution has had many startling twists and turns and is still under way.

In the beginning, Mao and his colleagues faced the immediate task of consolidating their rule and establishing the new government. After China's first census in 1953, People's Congresses were elected at various levels, and the National People's Congress, the State Council, and various ministries and bureaus were created as the institutions of the new government in 1954. Party organizations paralleled these government institutions, and party cadre held positions in both the party and the government with the party secretary in all units holding considerable influence over decision making. In general, the record of the last four decades is one of dramatic and rapid political, economic, and social change induced and directed, if not always controlled, by the leadership of the Chinese Communist Party.

Originally Mao declared that the new China would seek normal relations and trade with all nations, both East and West, but the Cold War led China to pursue a policy of "leaning to one side," relying upon the Soviet Union and countries of Eastern Europe for assistance. China's involvement in the Korean War and the resulting UN embargo on trade with China further isolated it from the Western-dominated international political and economic systems. A military stalemate in Korea enhanced China's position as an independent member of the socialist camp. Zhou Enlai, who represented China at both the Geneva and Bandung conferences in the mid-1950s, ably began to establish China's credentials as a significant new and independent member of the Third World.

To consolidate domestic support, the Chinese Communists would move into an area and redistribute the land to those who had no land or had farmed rented land. Members of the landlord-gentry class were dispossessed of their wealth and assets and many were killed. The introduction of collective farming in the mid-1950s began the steady process of moving ownership and decision making in agriculture from the household to ever larger collective units under the control of party cadre. In the urban/industrial sector, the state assumed control over the "commanding heights" of the economy-rail transportation, banks, former $\mathrm{Na}$ tionalist enterprises, and trade in essential commodities.

By the mid-1950s, central plans were drawn up to assign targets for inputs and outputs to factory managers, and private enterprises had become joint state-private enterprises subject to the state's plans. Labor bureaus recruited rural residents and school leavers and assigned them to jobs in urban enterprises. The state restricted migration from the rural to the urban areas and between urban centers. It also controlled wages and prices and rationed necessities in short supply. The state's monopoly was also extended over most domestic trade and transportation and all foreign trade. Thus, within a few short years the Chinese had transformed a largely private-enterprise, market economy into a socialist, Soviet-style economy without the serious upheavals and disasters that had accompanied this same transition in other socialist countries.

Also by the mid-1950s, the Chinese Communists had mobilized large segments of the population in support of the new government. Peasants had been given land reform that redistributed land to its tiller. Women benefitted from a new marriage law that made it possible for any woman to free herself from a marriage forced upon her in the past and increased her ability to earn an independent income. Young people's support was won by appealing to their patriotism and their new role in reforming society and the state. Workers were guaranteed jobs with fixed incomes and good fringe benefits. The new government also had greatly weakened the economic and political power base of any who might oppose it. The wealth of the landlord-gentry class was confiscated and its rights in the new political system were restricted. The liquid assets of the capitalist class were taken away through fines levied for past crimes "against the state and people" and capitalist en- 
terprises were made into joint state-private enterprises directly under state control. Former Nationalist government and military of ficials were imprisoned or sent to reform in labor camps.

In the early 1950s, the new government brought the rampant inflation they inherited under control and launched an economic development program with Soviet and East European aid, which resulted in a significant rate of growth and increase in the standard of living. The Chinese Communists' impressive record of accomplishments is a tribute to their dedication and organizational ability in the face of tremendous odds during the early years of their regime. However, China's long-term political, economic, and social problems remained to test the merit of the Chinese Communists' claim that they were the inheritors of the "mandate of heaven,' that is, the rightful leaders of the Chinese Revolution.

Obviously, China was not just another socialist country adopting and pursuing the traditional socialist Soviet model. China's size and low level of economic development meant that the bureaucracy's ability to control activity at the local level could never be as effective in carrying out government policies and economic plans as was called for in the traditional Soviet model. As in the past, the local level was really ruled by "local emperors" (the landlord-gentry class before 1949 and the communist cadre after 1949), not the central institutions far away in Beijing. To have a greater impact at the local level after 1949, the central authorities organized "mass campaigns" that swept through the country and, if successful, led to very dramatic changes in a very short time.

The Chinese also modified the rigid sense of legalism that is an aspect of the traditional Soviet model to fit their own environment; administrative rules and orders were not expected to be carried out to the letter of the law. Personal relations and networks of patronclient relations were much more important in negotiating the compromises that determined the results of administrative orders and policies.

\section{The Failure of Liberalization}

In 1956-57, the Chinese began to question their rather mechanical copying of the traditional institutions and policies of the Soviet model. The harsh manner in which the Soviet Union dealt with the popular uprising in Hungary led Mao to assert China's position as an independent member of the socialist bloc.

In a series of speeches Mao outlined his ideological arguments with the Soviet doctrine. According to Mao, the creation of socialism did not automatically eliminate classes and conflicts among the people. On the contrary, the state must work to reduce and ameliorate these potential conflicts or they would become more antagonistic and even lead to conflicts between the state and the people. In addition, each country must find its own road to socialism. In other words, the Soviets were wrong in dictating the specific set of institutions and policies appropriate for all socialist countries and intervening in socialist countries when they tried to determine their own model of socialism. To avoid the popular unrest that occurred in Hungary, the Chinese encouraged the people to express their opinions and complaints in a campaign to allow "a hundred flowers bloom, a hundred schools of thought contend." Finally, realizing that the highly centralized and bureaucratic Soviet model had a negative impact on initiative and the coordination of activities at the local level, speakers at the 1956 Party Congress called for a significant decentralization of control and planning in the economy, a restoration of some markets, and greater face-to-face negotiations among producers. These statements and calls to action signaled a desire for a much more liberal version of socialism.

Unfortunately, these hopes were soon dashed. Contrary to expectations, the "hundred flowers" campaign did not release pent-up discontent among the masses. It was the party cadre, high-level officials, and the intelligentsia who raised serious questions about the Communist Party's leadership and policies. This threatened to generate unrest among the masses, but before that could happen, the campaign was terminated and replaced by an "antirightist" campaign directed against those who had criticized the political leadership and its policies. The restoration of some markets and decentralization in the economy generated considerable private economic activity, which was viewed by those who supported a more rapid transition to socialism as portending the restoration of capitalism. This further justified the need for an antirightist campaign. As with the mass campaigns, these antirightist campaigns were periods of intense mobilization meant to silence those who objected to the party's rules and policies. Consequently, most Chinese desired to "know the party line" before taking a position and tended to mimic the terminology of the party line in reports and speeches on developments in China.

Like the hundred flowers campaign, the results of the economic reform and liberalization movement in 1956-57 proved disappointing. Soviet loans were running out in 1956-57, and the need to repay earlier Soviet loans meant that China had to maintain an export surplus in those years. Increased agricultural production and rapid industrial growth in 1955 led Chinese planners to substantially increase the level of investment in 1956. Unchecked migration to the cities and the rapid 
growth in urban employment led to a large increase in the wage bill in that same year, and the peasants were allowed to keep a larger share of their output as an incentive for joining the new agricultural cooperatives. All these sources of increased demand created shortages and inflationary pressures in 1956. Thus, in 1957, investment was cut to reduce inflationary pressures, imports were cut to secure the necessary surplus in the balance of trade, and migrants who were "visiting" the urban areas were rounded up and returned to the countryside. These moves helped restore balance in the economy but also led to a sharply lower growth rate in 1957.

\section{The Great Leap Forward}

In his speech on "The Ten Major Relationships" in the economy during the liberalization period in 1956, Mao explicitly rejected the big-push effort of economic development that relied on very large-scale investments in heavy industry in favor of balanced growth. By the end of 1957, however, Mao and others were rejecting what they viewed as constraints imposed on their development efforts by more orthodox development theories and their Soviet advisors' recommendations.

By the end of 1958, they launched a new mass campaign, "The Great Leap Forward," incorporating three main features.

First, China's swelling population was declared a major resource to rely upon in creating infrastructure and large-scale investment projects necessary to address China's development problems. Second, to reduce China's dependence on modern technology and imports of capital goods, both modern, capital-intensive technology and labor-intensive, indigenous technology would be used in developing China's economy. Third, to mobilize labor on a large-enough scale to achieve greater self-sufficiency in both agricultural and industrial production in the rural areas and a more equitable distribution of the fruits of labor, peasants were organized in communes that included many villages or former cooperatives. State-appointed cadres ran these communes and distributed the income both in kind on the basis of need and in cash on the basis of work done. This aspect of the Great Leap Forward campaign proved capable of introducing larger-scale socialist units of production, reduced the use of material incentives, and resulted in a more equitable distribution of income. As a result, the Chinese began to boast that they were achieving true socialism ahead of the Soviet Union.

The Great Leap Forward tried to ignore the constraints imposed by China's low level of economic development, its reliance on agricultural output produced by peasants motivated by material gains for their family, and the wastage of resources inherent in the creation of very small-scale, backyard workshops that produced poor quality industrial products using outdated technology, and it ended in economic disaster in 1959-60. When Peng Dehuai, the leader of Chinese forces in the Korean War, openly criticized Mao in the fall of 1959 for threatening to lead the Chinese into starvation, he was banished to the countryside. China's political leaders defended themselves by claiming that the policy was correct and that the cause of the crisis was poor implementation of the policy by lower-level cadre. Nonetheless, Mao was given an honorary title and withdrew from the day-to-day administration of policy. Liu Shaogi, Zhou Enlai, and other leaders who favored a slower and more traditional transition to full socialism were given responsibility for the restoration of political, economic, and social stability in China.

\section{Restoration}

The commune system was retained after the economic crisis, but the restoration of the economy was largely up to the initiative of the local authorities and the people. Production and distribution decisions were shifted to smaller groups within the commune. Private household plots and rural markets were restored, and steps favoring a return to household farming were introduced. Many enterprises were closed and investment projects were abandoned. Planning and control over economic activity was decentralized to the local level. Increasing agricultural production was given the highest priority. To sustain domestic consumption levels, the Chinese began to import foodstuffs on a significant scale in 1960 and turned to the West for needed supplies. Although Krushchev tried to take advantage of China's economic plight to resolve Sino-Soviet ideological and political disagreements, this attempt only precipitated the open break in relations. The many Soviet technicians working in China were withdrawn, and they took the blueprints for projects in China with them.

Most outside observers were not able to judge the depth of the economic crisis in 1959-60, discounting the worst accounts by refugees who fled to Hong Kong. Detailed data in China's statistical yearbooks released in recent years indicate through the age and sex distribution of the population that many Chinese died prematurely, fertility rates declined, and there was a high incidence of stillbirths and infant mortality. As a result of the rehabilitation policies, however, the earlier levels of per capita output and consumption were soon restored. At the end of that decade after the threat of famine had passed, the Chinese had a larger popula- 
tion and higher birth rate, but they also had lost their major source of external assistance and were relatively isolated with few friends and many enemies. China's leaders began searching for a new development strategy.

In the early 1960s there were some hopeful signs. China had weathered the crises and restored growth, while the reduced size of the planned and state sector of the economy allowed for considerable decentralized initiative, market forces, and private enterprise. The industrial base developed during the 1950s included most of the basic heavy industries, and a very sizable labor force of engineers and managers had been trained with the basic skills needed for economic development. Perhaps, like the brief period in the 1920s and again in the 1950s, the Chinese people could look forward to the creation of a stable government, peace, and sustained economic growth.

\section{The Cultural Revolution}

Unfortunately, as in those earlier periods, these hopes went unrealized. Mao and his utopian-radical followers feared that those who placed priority on economic modernization might restore capitalism. During the early 1960s, Mao, anxious to continue the revolution, issued repeated calls for a "socialist education" campaign that emphasized socialist values and behavioral norms. Serious attempts to carry out these socialist education campaigns took place mainly in the People's Liberation Army, under the direction of Lin Biao, Mao's hand-picked successor. Within the rest of the population, including the party and economic bureaucracy, these efforts to create model socialist men and women were half-hearted or fell on deaf ears.

The struggle between the two camps-the utopianradicals who wanted to continue the revolution with politics in command, and the moderate-developmentalists who felt further economic development was necessary before seeking radical political and social changes-came to a head in the Cultural Revolution during the mid-1960s. The moderate-developmentalists had used their control over the propaganda and cultural institutions - the press, theater, and educational system-to attack and criticize the individuals and policies of the utopian-radical camp. Thus, the Cultural Revolution began in the cultural realm. In its initial stages the moderate-developmentalists and their policies were attacked by their opponents in large-character wall posters, including one put up by Mao, and by demonstrations involving school age Red Guards.

These attacks became a mass campaign, and large numbers of temporary workers in the urban areas eventually joined the demonstrations, now aimed at politi- cal leaders and cadre throughout China. Lin Biao and Jiang Qing, Mao's wife, became predominant leaders of the Cultural Revolution, carrying it out in Mao's name, and they were able to remove their major opponents from positions of power. Zhou Enlai was able to retain Mao's support and used his control over the political and economic bureaucracy, seriously weakened by the intense factional strife that engulfed China, to preserve China's international security and the necessary minimum level of domestic social and economic stability.

The impact of the Cultural Revolution on the functions and policies implemented by China's political and economic institutions was considerable and its impact on the lives of the Chinese was immense. Those in the party and the government, intellectuals, artists, economic managers, and ordinary individuals who were identified as reactionaries were verbally and physically attacked; many were sent to work in the countryside, placed under house or office arrest, or identified as reactionaries and ridiculed in the streets. Some committed suicide, others died prematurely. Liu Shaoqi, "China's Khrushchev," was denied any medical care and died alone on a cot in mid-winter in an unheated building. Deng Xiaoping was sent to work in a factory. Many Chinese in positions of authority simply tried to avoid involvement by refusing to take any action or make any decisions.

As part of the attempt to instill the average Chinese with true socialist values and behavior, private economic enterprises and markets were eliminated, and the size of collective units was increased. Material incentives were replaced by more equitable income distribution schemes. Normative appeals were made to induce greater effort on behalf of society as a whole, and bonuses, salary increases, promotions, and university and army ranks were eliminated. The unit's net income was shared by the group. A hierarchy of responsibility and authority based on skills and education was denounced; everyone was supposed to become a peasant-worker-soldier. Each unit in the government, the economy, and society formed a revolutionary committee, consisting of representatives of the masses, both outside and within the unit, that controlled the unit's activities. Regions, economic units, and social groups were expected to reject specialization and division of labor and strive for self-sufficiency. The role of intraregional trade was reduced, as was China's trade with foreign countries. Emphasis was placed on creating industrial centers in the inland and backward regions of China.

University students were largely from the urban areas; therefore, the university was viewed responsible for producing members of the economic and political administration from among the urban elite. To break the perpetuation of a "new class," universities were closed 
and the students were sent to work in the countryside, the army, and in factories. When the universities were reopened, students were to be recruited from agricultural and factory work units, and recommended on the basis of their work ethic and dedication to socialism. To further close the gap between the rural poor and urban elite, one-third of the educators, entertainers, health workers, and other workers from the urban areas were required to work in the rural areas at any one time. And, in their foreign relations, the Chinese called on revolutionary forces throughout the world to rise up and overthrow the existing governments.

The utopian-radicals sought to create a classless and equitable society of socially dedicated individuals grouped in large-scale, economically self-reliant collective units that would be run by the masses. However, considering human nature and China's level of development, this mass campaign resulted in a breakdown in political control and civil administration, tremendous insecurity and instability, and an economic catastrophy.

By the end of 1969, Zhou Enlai, with Mao's support, sought to restore order, to revive the economy, to improve relations with the United States and the West, and to restore normal diplomatic relations with China's neighbors. Obviously, Mao's support for the utopian-radicals was wavering. By 1972, Zhou had rehabilitated Deng Xiaoping and worked with Deng to revive China's economy and foreign trade. Before Mao's death in 1976, an unstable balance of factions supervised by a senile Mao and a dying (from cancer) Zhou Enlai ruled China.

Thus, during 1970-76, the opponents of the Cultural Revolution, led by Deng, sought to rehabilitate China from the damages of the revolution while the Gang of Four led attempts to continue it. The Cultural Revolution, also referred to as the 10 terrible years, lasted from 1966 to 1976.

\section{The Post-Mao Reform Regime}

Mao hand-picked one of his most loyal followers, Hua Guofeng, to be his successor. When Mao died in September 1976, Hua and other political leaders rallied to overthrow the Gang of Four when they tried to seize power. In the midst of the political instability and economic recession that followed, Hua tried to form a ruling coalition and create a power base for himself. In fall 1977, a Party Congress endorsed his coalition and rehabilitated many important leaders purged during the Cultural Revolution. However, Hua's attempt to build a stable leadership coalition between those who had been loyal to Mao during the Cultural Revolution and those who had been purged, with himself as chairman of the party, proved to be unworkable.

Hua introduced a 10 -year modernization program in early 1978 . When this program began to encounter problems due to obstacles inherited from the past and its overly ambitious investment and import targets, Hua called for greater efforts and more investment, making the problems worse. Politically, as discussions of China's problems moved beyond blaming everything on the Gang of Four and began to question Mao's role in past mistakes, Hua argued that whatever Mao had done was correct, and whatever he had said should be done. Deng Xiaoping, on the other hand, argued that the truth should be verified by practice. Policy recommendations must remain consistent with the basic principles of socialism but still had to be tested in reality to see if they would work.

The party's Third Plenum (meeting of the Central Committee) at the end of 1978 is considered a major turning point in China's modern history. It was at this meeting that those who argued "truth from practice" won. From then on, although not continuously, Deng Xiaoping and his followers have emerged as the dominate leadership group, implementing a program of economic, political, cultural, and social reforms.

As a result, China has joined the world economic system and renounced its support for the armed overthrow of other governments. Domestically, China's economic reforms have experienced periods of retrenchment, but their cumulative impact over the past decade not only has been impressive, but has placed China with Hungary and Yugoslavia as countries that have shed a Soviet-type economic system for a different system. The Chinese make clear the experiment in economic reform is continuing and much remains to be done in the search for a new economic system that represents "socialism with Chinese characteristics.' In addition, the reform regime in China today strives not only for economic reforms but also for political, cultural, and social reforms. However, political and cultural reforms have been more difficult to implement.

\section{Contemporary Developments in China and the Asia-Pacific Region}

It is these turbulent developments in contemporary China that we are attempting to evaluate. We do not try to explain their ideological justification but agree with Deng's argument that truth comes from reality and practice. What is the reality of China today and how 
will that reality affect China's future and its relations with its neighbors in the Asia-Pacific region? The dayto-day reports of journalists and some scholarly analyses tend to be judgments on when or how fast China will become another capitalist country or whether the reforms will fail. It is our expectation, which is shared by most Chinese, that the reforms will continue in the foreseeable future with intermittent periods of advances and retreats. Thus, the achievement of an ideal politi- cal, economic, and social system is unlikely in the foreseeable future. It is more likely that the future will contain a mixture of traditional elements, socialist characteristics, and special Chinese innovations. Nonetheless, an appreciation of what has happened over the past decade in the post-Mao reform regime will contribute to a better understanding of current developments in China and that country's likely future course. 


\section{CHAPTER FOUR}

\section{China's Political Reforms}

hinese leaders have been frank, even brutal, in their assessment of the political institutions that they inherited from the Maoist period. In August 1980 in a speech now regarded as the starting point of political reform, Deng Xiaoping admitted that the Chinese political system was "plagued by problems which seriously impede the full realization of the superiority of socialism." Seven years later, at the 13th Party Congress, General Secretary Zhao Ziyang similarly noted that China's "current political structure . . . is no longer suited to our drive for modernization . . . or to the development of a socialist commodity economy."

Since the late 1970s, China's post-Mao leaders have been attempting to reshape the major dimensions of their nation's political life. The political reforms have reduced the influence of ideology over intellectual and cultural life, loosened administrative controls over the economy and Chinese society, institutionalized and regularized the political process, and expanded opportunities for political participation. The restructuring of the political system has been an integral part of the broader program of modernization and reform that China has been undertaking since the death of Mao Zedong in 1976.

As in the economic sphere, the reform of China's political system has been a halting and tortuous process. Chinese leaders have sponsored only a limited degree of political liberalization to avoid any challenge to the dominant position of the Chinese Communist Party. They have encountered obstacles that have prevented

Chapter four was prepared by Harry Harding, Senior Fellow, The Brookings Institution, Washington, D.C. them from accomplishing all their objectives, and many of their political reforms have had unintended and unwanted consequences. Despite the limits, the obstacles, and the dilemmas of reform, the Chinese political system today is considerably more relaxed, more institutionalized, and more consultative than it was when Mao Zedong was its paramount leader.

Chinese leaders have presented different rationales at various times to support their program of political reform. The logic of post-Mao political reform appears to contain four essential elements.

- An intellectual imperative: the need to relax ideological controls to foster greater creativity among scientists and intellectuals and to permit reforms that doctrine previously proscribed.

- A political imperative: the need to reshuffle China's political leadership and to restructure key political institutions to facilitate the adoption of sweeping economic reform and to enhance its chances for survival.

- An economic imperative: the need to redesign political institutions to reinforce and complement, rather than undermine or obstruct, the post-Mao program of economic modernization and reform.

- A societal imperative: the need to liberalize political life to ease the intense alienation felt by many sectors of Chinese society in the late 1970s, followed by the necessity of building a more responsive and consultative political system to maintain popular support for reform as it enters a more painful period in the late 1980 s. 
The relative weight of these four rationales has changed over time. In the late 1970s and early 1980s, the aim of political reform was to resolve the crisis of confidence resulting from the Cultural Revolution and to remove the political and ideological barriers to economic reform. In the late 1980 s, the goals have been to institutionalize the reforms, make China's administrative structure more compatible with a regulated market economy, and maintain popular support when the costs of reform are rising and the benefits to ordinary Chinese are starting to level off.

\section{The Intellectual Imperative}

One of Mao's purposes in launching the Cultural Revolution in the mid-1960s was to increase the role of ideology in all aspects of China's political life. As a result of his efforts, China in the mid-1970s had become a highly doctrinal polity in which the symbols of ideological commitment and conformity were virtually omnipresent. Ideological tracts crowded other works off the shelves of China's bookstores. Quotations from Marx, Lenin, and Mao-usually printed in boldfacewere sprinkled liberally through the pages of Chinese newspapers and periodicals. Huge red billboards with political exhortations painted in white characters punctuated China's urban landscape.

The ideology of the late Maoist period, now denigrated as ultraleftist and utopian, stressed the need to continue class struggle and exercise "proletarian dictatorship" against alleged enemies both inside and outside China. In the cultural realm, Maoism rejected traditional Chinese literature and art, belittled Western culture, and exalted a banal blend of socialist realism and revolutionary romanticism. It denigrated the role of markets, private ownership, foreign trade, and material incentives in the nation's economic development. Maoism ridiculed intellectuals as the "stinking ninth category" of counterrevolutionaries, condemned administrative officials as "party persons in authority taking the capitalist road," and called on industrial workers and the poorer peasants to seize power from the party apparatus.

Any sort of reform in the post-Mao era, whether economic or political, would have been impossible if this ideological straitjacket had not been loosened. Economic modernization, too, would have been severely limited by the constraints that doctrine imposed upon intellectual and scientific activity. Therefore, one of the first elements of political reform since 1976 has been a redefinition of both the role and the content of the ideology of the late Maoist period.

\section{The Redefinition of the Content and Role of Ideology}

To begin with, there has been a critical reassessment of the basic ideological principles of the past and the specific policies and historical episodes that had emerged from them. The key breakthrough in this regard occurred at the end of 1978 when the party's Central Committee first endorsed Deng Xiaoping's call to "seek truth from facts," rather than mechanically perpetuating whatever policies had been associated with Mao Zedong. Three years later, another plenary meeting of the Central Committee adopted a resolution on party history that repudiated the Cultural Revolution, the Great Leap Forward, and most of the other programs associated with Mao's later years. Since then, leading reformers have called for more "ideological breakthroughs" that would create a new body of Marxist ideology, suitable for China's conditions in the latter part of the 20th century.

That new doctrine, which the party has variously described as "socialism with Chinese characteristics" or the principles to guide national development during the "primary stage of socialism," is a much more liberal version of Marxism than the utopian Maoist vision that it is replacing. It stresses economic modernization rather than revolution, national unity rather than class struggle, and socialist democracy rather than proletarian dictatorship. It welcomes material incentives, diverse forms of economic ownership, markets for the allocation of goods and services, and fuller integration of China with the international economy. It values not only the traditional notions of self-sacrifice, fraternity, and collectivism but also competition, initiative, and risk taking. Signboards that once carried revolutionary messages now occasionally bear a new slogan, first popularized in the Shenzhen Special Economic Zone just outside Hong Kong, that neatly summarizes the spirit of the new age: "Time is money; efficiency is life."

In addition to changing the content of ideology, China's reformers have also reduced its role in economic and political affairs. A wide range of cultural and scientific issues can now be addressed on their merits, without reference to ideological considerations. Discussions of social and economic policy increasingly accept the legitimacy, even the desirability, of studying the experience of advanced capitalist countries and adopting whatever policies contribute to the most rapid rates of economic growth.

Chinese leaders are willing to tolerate the reemergence of religion-whether Buddhist, Moslem, or Christian-and some reformers explicitly acknowledge that ideology cannot in itself satisfy all the spiritual require- 
ments of the Chinese people. Increasingly, too, the Chinese Communist Party is basing its rule on an appeal to Chinese nationalism and is placing less emphasis on securing from nonparty members an active commitment to Marxism. In all these ways, the role of ideology in post-Mao China is steadily shrinking relative to the role of other bodies of belief.

Although the Chinese Communist Party is willing to purge its ideology of discredited principles, to incorporate new concepts that were once regarded as heretical, and to reduce the scope of activities governed by ideological concerns, it is not prepared to repudiate Marxism. The party describes the redefinition of official doctrine as the "enrichment and development" of its ideological heritage, not as its abandonment. Nor has the party agreed to allow the public presentation of ideological alternatives.

The party's reluctance to abandon Marxism arises from several considerations. The most fundamental of these is its recognition that the abandonment of Marxism or the acceptance of ideological pluralism would seriously undermine its own legitimacy, which is still rooted largely in its claim to having unique mastery of a scientifically correct body of social and political philosophy. Other factors are at work as well. Many members of the party appear to require the reassurance that the reforms of the post-Mao period are in keeping with Marxist traditions and are still intended to lead toward an ideal communist society. And a sizable number of ordinary citizens, including many intellectuals, also hold to the traditional Chinese concept that good governance requires, and the unity of society demands, that the state uphold an official doctrine and educate both of ficials and ordinary citizens in its basic tenents.

However, the redefinition of official doctrine does not appear to have filled the moral and political vacuum created by the discrediting of utopian Maoism. Many intellectuals appear to prefer the comprehensive and programmatic qualities of ideology to the pragmatic, experimental approaches to policymaking now being practiced in post-Mao China. Many peasants wonder whether the liberal rural policies now described as appropriate to the "primary stage of socialism" will be abandoned when the party decides China has entered a more advanced phase of development. The alternative belief systems now being tolerated or encouraged-nationalism, pragmatism, science, and religion - have not yet created a sense of sacrifice or unity among the Chinese people comparable to that engendered by Maoism. Indeed, Chinese society seems plagued by apathy, materialism, and moral decay, as reflected in a steady rise of corruption, crime, and other forms of social deviance. As economic reform enters a more delicate stage, therefore, the legitimacy of the
Chinese political order still appears to rest on a rather fragile base.

\section{The Political Imperative}

The political leadership that emerged from the Chinese Cultural Revolution was, in several respects, ill-suited to a program of sustained economic or political reform. Fully half of the members of the Chinese Communist Party had been recruited when class background and revolutionary zeal, rather than formal education or technical competence, were the principal criteria for membership. The Cultural Revolution had produced a highly factionalized and unstable political system, featuring sharp divisions within the elite, the arbitrary exercise of power by individual political leaders, and abrupt and often violent changes of leadership.

In this context, it was necessary for Deng Xiaoping and the other reformers to reconstitute the national leadership in ways that would support a program of economic and political reform and then to institutionalize the system to maximize the chances that reform would survive Deng's eventual departure from China's political stage. These political imperatives provided a second rationale for restructuring China's political system.

Gradually, Deng was able to remove key conservatives, such as Mao's immediate successor, Hua Guofeng, from the central leadership of the party, replacing them with officials more supportive of reform. He then utilized his growing political base in Beijing to restaff the party and state bureaucracies at lower levels. Between 1978 and 1985, the reformers achieved a massive turnover of state council ministers, provincial first secretaries, and provincial governors-comparable in scale, although not in method, to the great purges of the Cultural Revolution. Fully 89 percent of the cabinet members and 93 percent of the provincial first secretaries and governors who had been in office in 1978 were removed by 1985 . They were replaced, on the average, by officials who were younger, better educated, and who presumably will be more supportive of reform after Deng's death.

Finally, Deng attempted to create a regular system for leadership rotation to avoid the kind of succession crisis or struggle for power that could jeopardize reform. Deng's plan was to specify limited terms of office for top party and state leaders, to move senior officials into ceremonial positions once they had served their terms, and to establish predictable patterns of promotion from the ministries and provinces into the party Secretariat, the State Council, and the Politburo. Deng also tried to reestablish the norms of collective leader- 
ship, free debate, and party discipline among the elite that had been so seriously shattered during the Cultural Revolution.

It is clear that, through these strategies, Deng Xiaoping has been able to shift the center of gravity of the Chinese political spectrum rather decisively in the direction of reform. In 1976-77, when Deng began to challenge Hua Guofeng, the reformers were on the fringe of Chinese politics, with the predominant position held by those who wished to restore the efficiency and vitality of a centrally planned economy and a Leninist political order. Today, a little more than a decade later, Chinese politics is dominated by those committed to a sustained program of economic and political reform, with more conservative leaders relegated to subordinate positions.

This is not to say, however, that the national leadership is united, despite the customary Chinese efforts to insist that it is. Although virtually all leaders in Beijing support some kind of reform, there are still significant differences over how far to go, how fast to proceed, and what strategies to adopt. The differences of opinion are even wider at lower levels of the party and state bureaucracies.

Differences of opinion are normal within any political system and should be expected, and even welcomed, in a country of China's size and complexity. They need not necessarily have a destabilizing impact on the political system, since China has made marked progress toward ending the bitter and destabilizing factionalism that characterized the late Maoist period. Nonetheless, it is also clear that these divisions within China's leadership are not being expressed or resolved entirely through institutionalized mechanisms.

The best example of the problem is the fate of $\mathrm{Hu}$ Yaobang, first the chairman and then the general secretary of the party from 1981 until early 1987. Hu's apparent disinterest in ideology, alleged tolerance of dissent, and advocacy of a rapid retirement of veteran party officials made him controversial, as did his reputation for spontaneous and ill-conceived statements that occasionally departed from official party policy. Ultimately, a nationwide series of student demonstrations in late 1986 and early 1987, which called for greater democracy and accelerated political reform, provided a convenient pretext for Hu's removal. Hu's dismissal in January 1987, disguised as his "resignation" from the post of party general secretary, was engineered by a group of senior conservative party leaders (some of whom had formally retired from the Politburo), endorsed by Deng Xiaoping, and then implemented by an irregular meeting of the Politburo. The dismissal took place even though Hu's term of office would have ended at the 13th Party Congress later that same year.

Zhao Ziyang, Hu's successor as general secretary, ap- peared to be encountering similar political difficulties by the middle of 1988 . Where Hu had been controversial for his stand on various political and organizational issues, Zhao came under fire for his management of the economy. Zhao's advocacy of export-processing zones along the Chinese coast, his insistence upon rapid price reform, his support for other radical economic reform measures, and his apparent acceptance of a relatively high rate of inflation aroused the skepticism of more conservative leaders both inside and outside the Politburo. Once again, Deng's support for his heir apparent seemed to waver, as he reportedly declared, "I shall not protect anybody, and whoever fails to give a good account of himself should go." This immediately created intense speculation that Zhao would lose control over national economic policy and might even be forced to resign from the general secretaryship in the same way as $\mathrm{Hu}$ Yaobang.

\section{Deng Xiaoping's Current Role}

The fate of Hu Yaobang in 1987 and the spectacular rumors about Zhao Ziyang in 1988 illustrate one of the most striking dilemmas of political reform in post-Mao China. Unlike Mao Zedong, who held on to the chairmanship of the party until the bitter end, Deng has attempted to withdraw gradually from a formal role in Chinese politics to minimize the impact of his eventual death on the political stability of his country. As of 1988 , he holds only one formal institutional position, that of the chairman of the party's Military Affairs Committee. By his own account, he does not participate in the drafting of the detailed programmatic statements on economic or political reform. And yet, Deng has clearly been China's paramount leader throughout the entire decade of reform and has intervened decisively when critical questions of direction, pace, or personnel were at stake.

The dilemma is that, in the short run, the success of reform has critically depended on Deng's personal prestige and political acumen; and yet, over the long run, the fate of reform rests on his ability to remove himself from politics to ensure a smooth transition of power to his successors. Whether Deng has struck the proper balance between these two imperatives remains to be seen, but his continued active involvement in politics does raise the possibility that his eventual departure from the political stage will create a vacuum of power that could prove disruptive.

The contradictions inherent in Deng Xiaoping's ambiguous role in Chinese political life are echoed in the equally ambiguous standing of other senior leaders throughout the Chinese political system. One key element in Deng's succession arrangements has been to ease veteran officials into comfortable retirement by 
offering them positions as advisors to party and government bodies at various levels. And yet, there is ample evidence that these older officials, many of whom have little firm commitment to reform, are continuing to play an active role in Chinese politics at both the national and local levels. In many provinces and cities, they continue to influence key personnel appointments; in Beijing they have apparently formed the core of the opposition to both $\mathrm{Hu}$ Yaobang and Zhao Ziyang. The senior officials form a group of skeptics and critics of the reform program who may attempt to assert their views more actively should economic reform encounter further difficulties.

\section{The Economic Imperative}

From an economic perspective, the Chinese political system on the eve of reform combined the worst features of Leninism and Maoism: it intruded heavily into the economy but was poorly designed to support either economic modernization or reform. Government officials were, in many cases, overaged and undereducated. The state bureaucracy comprised a huge array of administrative agencies, whose job it was to exercise close and direct control over every detail of economic activity. At the same time, the party inserted itself into every other institution in the country-from factories to universities to government agencies-and took as its mandate the maintenance of political loyalty and ideological orthodoxy rather than the promotion of economic development.

As the reformers saw it, therefore, the very structure of the political system was an obstacle to economic reform. It would be difficult to encourage entrepreneurial activity by enterpise managers if their decisions were constantly subject to interference by local party committees or government agencies. The transition to a regulated market economy would be nearly impossible if the state bureaucracy continued to consist mainly of agencies designed to exercise direct administrative control rather than indirect regulatory oversight. Foreign investors would be reluctant to launch projects in China if they had to deal with unqualified and unimaginative officials and inefficient and hesitant bureaucratic agencies. For all these reasons, successful economic reform required political restructuring as well.

The political reforms that have followed from this economic rationale have included five principal components. First, there has been an effort to reorganize the state bureaucracy to make it more compatible with the needs of economic development and reform. Agencies responsible for central planning and for direct administration of economic activity are being eliminated, merged, or streamlined. Conversely, government organi- zations responsible for economic regulation (such as the banks, auditing agencies, statistical bureaus, and taxation agencies) are being strengthened and expanded. This program, which was launched on an experimental basis at the municipal level in 1986 and extended to a small number of central ministries in early 1988 , is supposed to be completed at some point in the early 1990s.

Second, Chinese reformers have announced their intention to rationalize and modernize their nation's civil service. Recruitment to government positions will be on the basis of open competitive examinations, with young officials drawn increasingly from the nation's pool of college graduates rather than from the ranks of the workers and peasants. Civil service positions will be graded, job responsibilities will be more clearly specified, and procedures will be created for the systematic training, evaluation, promotion, discipline, and retirement of officials. Ultimately, these new procedures will be embodied in the first civil service law of post-1949 China, the drafting of which reportedly is well under way.

Third, discussions of political reform have also hinted at measures to decentralize administrative power in an effort to grant provincial and municipal governments greater power to adopt their own regulations and legislation, greater freedom to adapt central policy to local circumstances, and greater autonomy over financial affairs. As one measure of decentralization, investments made by local governments and individual enterprises outside the state budget constituted more than 60 percent of the total in 1986, as compared with less than 25 percent during the Fifth Five-Year plan in the late 1970s. This degree of financial decentralization is already threatening both the revenue base of the central government and its control over how the nation's financial resources are invested.

A fourth aspect of political reform has been to create a more rational policymaking process, particularly at the national level. Academic specialists, housed in a growing number of research institutes connected with major government and party agencies, have more influence over the content of national policy. Drafts of central documents are circulated for comment to administrators, academic specialists, local officials, and enterprise managers before being formally considered by the party Politburo, the State Council, or the National People's Congress. Foreign experts, in organizations such as the World Bank, are frequently serving as consultants and advisors. Although China's policy research institutions remain understaffed and undertrained and policy analysis remains rather rudimentary by Western standards, the reforms have created the basis for a more objective and pragmatic policymaking process. 
Finally, and most important, the current political reforms envision a distinctively reduced role for the Chinese Communist Party in routine political and economic affairs. The party is no longer to exercise direct control over administrative matters that are the proper province of government agencies, industrial and commercial enterprises, or public organizations. To that end, the party's control over government appointments will be restricted under the civil service law to a top echelon of policymakers at each level of government, with lower-ranking officials governed by civil service procedures. The party cells in central government agencies are being abolished, and party departments in the localities that overlap with government agencies will also eventually be eliminated. In grassroots organizations, it is now the director or manager who is to exercise dayto-day responsibility, with the party secretary in a supervisory position.

Of all the political reforms discussed thus far, these five measures are perhaps least advanced in both design and implementation. But it is already apparent that both the party apparatus and the government bureaucracy are maintaining tenacious holds over their previous areas of responsibility, despite every effort to relax them. This suggests that economic liberalization may require a further, and even deeper, reform of both the political structure and the system of economic ownership.

\section{More Radical Reforms}

One problem concerns the continuing role of the government in the economy. Despite the steps to increase enterprise autonomy, the state bureaucracy has proven inventive in finding ways to retain considerable power over state enterprises. Even under the reforms, government agencies still must approve decisions to alter an enterprise's product line, build a new factory, or shut down existing production facilities. The state bureaucracy still appoints enterprise managers, allocates key inputs provided under mandatory planning, and negotiates the contracts for annual production and profit quotas. The proposals to transfer administrative authority from central bureaucratic agencies in Beijing to their counterparts in China's various provinces and municipalities may simply exacerbate the problem, for decentralization is giving even greater power to local agencies that appear eager to interfere in the workings of the marketplace.

The continued control of the state bureaucracy over the industrial economy has led some Chinese reformers to propose an even more radical restructuring of the system of ownershíp of state industry. The proposals, as yet adopted only on an experimental basis, vary widely. They include the leasing or sale of smaller state enterprises to individual entrepreneurs or groups of workers, the expansion of collective and individual enterprises to constitute a greater share of the national economy, and the creation of boards of directors to assume supervisory responsibilities over the larger state corporations. But the common denominator is to break the connection between bureaucratic administration and economic management by creating new forms of ownership that are independent of the state.

Similar problems are apparent with regard to the role of the party. Even under the reforms, the party retains the responsibility for ensuring the implementation of national policies and directives and the authority to nominate or approve the appointments of leading officials in every other organization. Although some party secretaries support reform, others are using these residual powers to obstruct or distort the implementation of various reform programs.

Thus, some scholars and policy analysts have suggested even more radical changes in the structure of the party to further restrict its control over basic-level organizations. Some have argued that it is necessary to abolish party committees in factories, universities, research institutions, and enterprises altogether so that full authority can be vested in the hands of the director or manager. Others have pointed out that the party's continuing control over personnel appointments imposes a serious limit on the autonomy of officials in other institutions and have therefore proposed that the party's power over nomenklatura be restricted to the highest-level policymaking positions in government and eliminated in other areas. Although such far-reaching proposals have not yet received a sympathetic hearing, they may eventually become key elements on the agen$\mathrm{da}$ of subsequent rounds of political reform.

\section{The Societal Imperative}

By the time of Mao Zedong's death in 1976, the Chinese political system had become at once increasingly totalitarian and increasingly illegitimate. The totalitarian features of the system - the construction of a Leninist party, the formation of a vast network of mass organizations under party control, the promulgation of an official ideology, and the mobilization of popular support for redistributive policies-had been created in the 1950 s, during the early years of the new government. But they had been exacerbated during the antirightist campaign of 1957, the Great Leap Forward of 1958-59, and particularly during the Cultural Revolution of 1966-76. In all these political movements, Mao had at- 
tempted to sustain a high level of popular mobilization for economic development and a high degree of mass struggle against poorly defined class enemies inside and outside the party.

The result of these campaigns, however, was not popular support but mass alienation, particularly in urban China. Intellectuals were the principal targets of persecution in both the antirightist campaign and the Cultural Revolution. Urban workers saw their levels of consumption virtually stagnate after the mid-1960s. Young people, encouraged to join the Red Guards during the Cultural Revolution, were dispatched in the tens of millions to the rural areas in the late 1960s and early 1970s, with little prospect of returning to their homes. By 1980, China's post-Mao leadership acknowledged that, unless remedial measures were taken, China potentially faced a political crisis comparable to the one that Poland was then experiencing.

As the post-Mao economic reforms have unfolded, the danger of a crisis of confidence in the party's leadership has taken on a new dimension. The leadership is aware of the resentment and concern being created by some of the unintended consequences of reform, particularly inflation, inequality, corruption, and abuses of power. It also recognizes that even more painful reforms lie ahead, including price reform, wage reform, housing reform, enterprise bankruptcy, and the like. Although popular support for the general concept of reform appears to remain fairly strong, there are growing complaints about some of the particular problems that have been associated with the reform program, and even some nostalgia for the economic security and moral commitment of the Maoist era. Increasingly, therefore, political restructuring has been aimed at preventing a new crisis of confidence from emerging as a consequence of reform.

One important early measure was the removal of the political and class labels that had been assigned to every Chinese citizen during the Maoist years. In 1977, virtually all those who had been landlords, rich peasants, or capitalists before 1949 were politically rehabilitated. Beginning the following year, similar treatment was extended to approximately three million Chinese who had been tarred as "rightists" or "counterrevolutionaries" during the antirightist campaign and the Cultural Revolution. In the subsequent decade, the prerevolutionary class background of one's family has come to have much less influence on the chances for university education, employment, or even party membership.

A second significant reform has been the relaxation of the political controls over most aspects of ordinary life. The individual Chinese today has more choice than ever before over his occupation, place of living, and life-style. Ordinary Chinese now spend much less time in political study and are freer to practice religion. Artists, writers, and scholars have much greater freedom of inquiry and expression. Consumers àre now able to obtain more fashionable furniture, clothing, and hairstyles and to enjoy a wider range of hobbies and leisure activities. Attitudes toward premarital sex and divorce have become noticeably more relaxed.

There are also efforts to make the remaining political controls more predictable and less arbitrary. China has made considerable strides toward the creation of a more complete legal system that specifies the substantive and procedural rights of Chinese citizens. A new criminal code and code of legal procedure were adopted in 1979. Laws governing the press, publication, association, assembly, and demonstration are being drafted as well as an administrative litigation law, providing citizens with relief against illegal or unjustifiable government actions.

Recent reforms have also involved the establishment of more channels of communication between political leaders and ordinary citizens. The press now carries somewhat fuller accounts of major government and party meetings, including unprecedented reportage on plenary sessions of the Politburo. The advantages and disadvantages of various competing policy options, in such areas as price reform and enterprise reform, are more openly debated in both scholarly journals and the popular press. Meanwhile, public opinion on major policy issues is being solicited through investigative reporting, contacts with mass organizations and professional associations, attitudinal surveys, and other mechanisms for what is described as "consultation and dialogue."

The revitalization and restructuring of legislative and deliberative bodies, particularly at the national level, has been another feature of recent political reform. Competitive elections for delegates to local and countylevel people's congresses were authorized in 1982 and made mandatory in 1986. A degree of competition has also been introduced into provincial and national government; the Standing Committee of the National People's Congress, the governors of eight provinces, and the vice-governors of 29 provinces have now been selected by the relevant legislature through competitive elections. The National People's Congress engages in discussion and debate of various policy issues much more openly and has demonstrated its ability to delay or modify important elements of legislation, secure revisions in the state budget, and block a limited number of personnel appointments. The Chinese People's Political Consultative Conference, a deliberative body without formal legislative powers, provides expanded channels of consultation with intellectuals, scientists, entrepreneurs, and other elite groups outside the Communist Party. 
Finally, a small degree of democratization is being introduced into the Chinese Communist Party itself. There have been some competitive elections to party congresses and committees at various levels, and the 13th Party Congress decided that the practice should be made universal in the near future. At the congress itself, more candidates were nominated for membership in the Central Committee than for which there were vacancies, and at least one prominent conservative leader, Deng Liqun, actually went down in embarrassing defeat.

\section{The Limits of Political Liberalization}

Despite these unmistakable signs of progress, there remain significant limits on the design and implementation of these aspects of political liberalization. An intrusive birth control campaign, controls on publications, and periodic criticisms of unorthodox intellectuals and works of art indicate that the hand of the state remains strong. The revised legal system still lacks provisions regarded as essential in much of Western law, including the presumption of innocence, protection against self-incrimination, and the practice of an aggressive courtroom defense. Dissidents and protesters are still subject to arbitrary arrest, lengthy detention without trial, torture and solitary confinement, and severe prison terms for loosely defined offenses. The party controls the nominations for contested elections, and legislative bodies do not yet have the power to introduce their own legislation. Generally, the totalitarian institutions of the Maoist era have been deactivated, but not yet dismantled, and the newly invigorated representative institutions enable the Chinese Communist Party to seek advice and opinion without forcing it to be accountable or responsive to popular demands.

Moreover, Chinese leaders continue to reject the possibility of an independent press, truly independent interest groups, independent opposition parties, or an independent judiciary and legislature. Although the party now chooses to consult with various sectors of society as it makes its policies, it is not prepared to engage them in a genuine competition for political power.

And yet, even this limited degree of political liberalization has already produced serious dilemmas for the Chinese Communist Party. Although intended to reinforce reform in other areas, the political relaxation that has occurred since 1978 has in some ways increased the ability of various sectors of Chinese society to obstruct the aspects of reform to which they object. The National People's Congress blocked for several years the adoption of a national enterprise law that would have made possible the closing of unprofitable state enterprises. Strikes and slowdowns by workers have hampered the implementation of wage and price reform.
In all these ways, in China as in the Soviet Union and Eastern Europe, political liberalization may paradoxically serve not to reinforce, but to hinder, efforts at economic reform.

A further dilemma is that political liberalization and economic reform are producing pressures for more pluralism. Even though Western concepts of multiparty democracy, competing ideologies, and independent interest groups are not deeply rooted in Chinese tradition, a key trend in recent years has been the emergence of a small but significant protest movement that is calling for greater democratization. Ethnic questions, although not as central in Chinese politics as in the Soviet Union, have also been the subject of protest, as evidenced by the recent riots in Tibet. As levels of education continue to rise, as economic reform creates a larger class of professionals and entrepreneurs, and as contact with Western societies increases, the pressures for democratization and pluralism are almost certain to grow. Of particular concern to Chinese leaders is the possibility that those protesting specific social and economic problems will join forces with those who want sweeping political reform, creating an alliance between workers and young intellectuals that the regime might find difficult to control.

Chinese leaders will have to decide whether to respond to these pressures by sponsoring further political reform or by reasserting political control. Political liberalization may be necessary to prevent further alienation of the Chinese people from their government, but it may also lead to demands for social and political change that the Chinese Communist Party finds unacceptable and may hamper the adoption and implementation of necessary but unpopular economic reforms. Conversely, political control may temporarily restore order, suppress dissent, and force the adoption of unpopular reforms but will generate even more dissatisfaction with the structure of the political system. Although Chinese leaders have alternately tightened and relaxed political controls as conditions have warranted, thus far the overall direction is toward greater liberalization. It remains to be seen whether this pattern will continue in the second decade of reform, when social and economic contradictions are almost certain to become more acute and pressures for more fundamental political change are likely to grow.

\section{Conclusion}

The political reforms in post-Mao China have involved efforts to disengage both the Chinese Communist Party and the state bureaucracy from the detailed adminis- 
tration of the economy, to relax ideological controls over intellectual life and public policy, to create a more modern administrative and legal system that can effectively regulate the marketplace, and to make political institutions more responsive to key social sectors. As a result of these efforts, China's political system has evolved, though haltingly and gradually, toward a more relaxed, consultative, and institutionalized form of authoritarianism. The reforms have led to the reemergence of a wide range of social, cultural, intellectual, and economic activities that are relatively free of political interference. In this regard, mainland China today is strongly reminiscent of the Taiwan of the mid-1960s, although with the remnants of totalitarian institutions that the Kuomintang never created.

But mainland China has not taken the next step, from authoritarianism to democracy, as Taiwan appears now to be doing. Such a development would involve the dismantling of the grassroots organs of the party, the further ritualization of ideology, the tolerance of independent interest groups and publications, and, ultimately, the emergence of independent opposition parties that could challenge the Chinese Communist Party in elections for executive and legislative positions.

Such a transition for authoritarianism to democracy in China must be regarded as highly unlikely, at least for now. Some of the more open-minded reformers do favor a pluralistic, or at least a quasi-pluralistic, political system. But the leadership of the Chinese Communist Party is as yet unwilling to accept such a reduction of its political power. Although there is substantial agreement among party leaders on the need for sweeping economic reform, even to the point of creating a regulated market economy with significant levels of private and collective ownership, the consensus on political restructuring still favors the maintenance of an essentially authoritarian system. Many older intellectuals outside the party also believe that China is not yet ready for mass pluralist democracy.

For the foreseeable future, therefore, political reform in China is likely to involve the completion of the agenda outlined above and measures to resolve the dilemmas that political liberalization has produced. A somewhat freer press, more active interest groups, the extension of direct elections to the higher levels of the people's congresses, a more lively legislative process, further progress toward the creation of a legal system, more democracy within the Chinese Communist Party, and the development of a more rational administrative apparatus can all be envisioned. But the prerequisites of pluralism, including independent political parties and interest groups, are unlikely to be created in the next several decades.

Nevertheless, the pressures for further reforms already exist and are likely to grow. As China continues to modernize and as the rest of East Asia experiments with greater pluralism, demands for more fundamental political change will become a permanent feature of the Chinese political debate. Over the distant future, it is not inconceivable that, if economic reform can be sustained, China will also gradually evolve toward a more pluralistic political order. 



\section{CHAPTER FIVE}

\section{China's \\ Economic Reforms}

$\mathbf{E}$

conomic reform programs throughout the socialist world, as well as in the nonsocialist world, are usually preceded by a realignment of political forces, which is necessary for enabling the introduction of revolutionary changes. In China the death of three senior leaders of the Chinese communist movement-Zhou Enlai, Zhu De, and Mao Zedong-all in a single year and the ensuing emergence of Deng Xiaoping and his followers as the new leadership group by the end of the 1970s was just such a major realignment of political forces, providing the opportunity for introducing a major program of economic reform. Deng and his followers did not miss this opportunity.

\section{The Economic System Inherited by the Post-Mao Leadership}

Despite its low level of economic development in the early 1950s, China was able to achieve significant rates of growth using a Soviet-type, centrally planned economic system. China's abundant labor and raw material supplies and Soviet technical assistance and capital goods helped achieve this result. The disasters of the Great Leap Forward campaign and the Cultural Revo-

Chapter five was prepared by Robert $F$. Dernberger, Research Associate, East-West Center, and Professor of Economics at the University of Michigan. lution were overcome by relaxing central controls and increasing reliance on foreign trade. However, it became increasingly clear that the Chinese would be unable to sustain high rates of growth and increase the standard of living without undertaking major changes in their economic institutions, strategies, and policies.

The problems of the Soviet-type economic system are well known, but China's specific adaptations to that economic system, economic policies, and economic circumstances made those problems even worse. For example, as in other Soviet-type economies, China's peasants and their land were organized into collective units. While China did introduce state-owned and -operated farms, these have not played a large role in China. Instead, during the Great Leap Forward campaign, the Chinese introduced the commune, a very large unit that included several villages. This Chinese variant of the socialist agricultural collective system meant that day-to-day operational and distributional decisions were too highly centralized for a laborintensive type of technology in what was essentially garden farming. In addition, the Chinese strictly controlled migration out of the rural-collective sector. This dammed up the increase of population in the collectives, which the output of the collectives had to sustain.

The Chinese realized the problem that the vertical distance between the central planners and the economic units at the local level posed soon after they introduced the Soviet-type economic system in the 1950s. To adapt the system to better meet their needs and relieve some of the burden on the central planners, they significantly 
decentralized the control and planning of economic activity. Yet, without a market and realistic prices, the local level units were unable to coordinate their economic activities. Thus, the Chinese economic system remained a planned system, but the planned targets were developed through negotiations between the different levels of political authority. Nonetheless, the Chinese leadership tried to remedy the coordination and planning problems at the local level by continually adding proscriptions on what the local authorities could do and exhorting them on what they should do to speed up the transition to true socialism.

Among the Chinese economic strategies and policies that added to China's growing economic crises in the mid-1970s were the attempts to reduce dependence on specialization and trade by emphasizing steel and grain production as the keys to China's modernization; periodically instituting campaigns requiring the mass mobilization of labor; restricting markets and market prices and private and individual enterprise that would have helped fill in the gaps in the state-controlled and -planned sectors of the economy; and moving industries inland despite the very high costs of doing so. The planners were more often motivated by political and ideological objectives than by economic objectives. For example, the Soviet-type economic system recognizes the need for material incentives; however, in an attempt to achieve true socialism as quickly as possible, the Chinese introduced measures to achieve a more equitable distribution of income, severing the relationship between the work individuals did and the income they earned.

Despite the inefficiencies of a Soviet-type economic system and the increased inefficiency resulting from
Chinese adaptations to that system and their economic strategies and policies, China's growth in the three decades after 1949 is impressive. In real terms, China's national income increased at an average annual rate of 6 percent between 1952 and 1978, which is among the highest growth rates of any country in the world during that period. There are three major explanations for this growth: (1) the creation of stability and peace, allowing rehabilitation and recovery in the economy; (2) China's very rich resource endowment and abundant labor supply; and (3) the ability of the Soviet-type economy to do one economic task well-mobilize resources on a significant scale.

\section{Growth in the First Three Decades}

The story can be told with statistics. Between 1952 and 1978 , the state's revenue from domestic sources increased from 29.5 percent to 37.2 percent of national income. Investment in construction projects increased from 26.5 percent to 40.7 percent of the state's expenditures, and the net value of fixed assets in state-owned industry increased an average 13.9 percent annually. Thus, the national income growth of 6 percent a year resulted largely from the growth in industry of an average 11.3 percent annually as compared to the 2.2 percent growth rate for agriculture.

During the same period the population increased 2 percent a year. After the initial period of recovery and

Table 5.1 Investment and Consumption in China: 1952-87

\begin{tabular}{|c|c|c|c|c|}
\hline \multirow[b]{2}{*}{ Year } & \multirow{2}{*}{$\begin{array}{l}\text { Average annual } \\
\text { rate of growth } \\
\text { in national income } \\
(\%)\end{array}$} & \multicolumn{2}{|c|}{ Per capita (1985 USS) } & \multirow{2}{*}{$\begin{array}{l}\text { Investments in fixed } \\
\text { assets as a share of } \\
\text { national income } \\
(\%)\end{array}$} \\
\hline & & National income & Consumption & \\
\hline $1952-65$ & 5.4 & 67.84 & 49.73 & 18 \\
\hline $1966-78$ & 7.2 & 106.82 & 73.46 & 23 \\
\hline 1979 & 7.0 & 144.05 & 94.21 & 25 \\
\hline 1981 & 4.9 & 156.70 & 112.35 & 20 \\
\hline 1982 & 8.3 & 167.13 & 119.00 & 23 \\
\hline 1983 & 9.8 & 181.46 & 127.56 & 23 \\
\hline 1984 & 13.5 & 203.72 & 139.55 & 25 \\
\hline 1985 & 13.1 & 227.92 & 147.69 & 26 \\
\hline 1986 & 8.0 & 242.66 & 158.22 & 27 \\
\hline 1987 & 10.5 & 264.23 & 172.54 & 28 \\
\hline
\end{tabular}

Source: State Statistical Bureau, Zhongguo Tongji Nianjian: 1988 (Statistical Yearbook of China), Beijing: Chinese Statistics Publishers, August, 1988. 
mobilization of labor, peasant per capita consumption increased at an annual rate of only 1.5 percent between 1957 and 1978, while that of the nonagricultural residents increased by 2.5 percent a year. More important, per capita consumption of grains was 3.7 percent lower in 1978 than it had been in 1957 and consumption of edible vegetable oils was over 30 percent lower. Obviously, worker and peasant welfare, measured in terms of basic consumer goods and income, was not increasing at a rate anywhere near the growth rate for the economy as a whole.

In 1978 after more than a decade of attempting to make incomes more equitable, over one-third of the peasants had incomes that were 25 percent or more below the already relatively low average peasant income, and one-fourth of the urban households had per capita incomes of less than 75 percent the average income for all urban households. In short, after three decades of rapid growth, China still had a sizable population whose per capita income was well below the average per capita income, and the average per capita income was relatively low and not increasing very rapidly.

Developments on the supply side of the economy were not any more promising. In the investment sector between the mid-1950s and the late 1970s, the length of time to complete projects and the costs per square meter to construct buildings doubled. In agriculture, the increase in purchased inputs per unit of output meant that peasant net incomes were not increasing even though gross outputs were rising. In industry, costs per unit of output were increasing, total profits per unit of cost were declining, and total productivity of land, labor, and capital was stagnating. In brief, despite its rapid growth, the economy was operating well below its potential and was devoting a disproportionate amount of resources to investment for the sake of rapid growth, while the population was being allowed only marginal gains in its standard of living.

How long this process of rapid growth without productivity gains, greater efficiency, and consumer satisfaction could have continued is hard to answer. However, the high average growth rate from 1952 to 1978 did reveal a downward trend over this period, and the Chinese were experiencing a growing gap between potential and actual output. This latter problem was created by the many bottlenecks, which were becoming serious in the mid-1970s, especially the growing shortages of energy, transport, construction materials, skilled labor, and managerial talent. In a market economy, market prices adjust to reflect these shortages and bottlenecks. In China, however, in the absence of market mechanisms it was the political leaders and planners who had to recognize these bottlenecks and imbalances and adopt new policies, priorities, and allocation decisions to correct them.

\section{China's Economic Reform Program}

With the death of Mao and the overthrow of the Gang of Four, the post-Mao leadership had not only an interest in but the opportunity to make far wider institutional, strategy, and policy changes than mere adjustments to resource allocation priorities. However, as the new leaders were consolidating their political control at the end of the 1970s, their first attempt at reform was to criticize Maoist economic principles and replace them with many of the socialist principles that had governed Chinese economic policies during the 1950s. Fairly early in the economic reform program, the postMao leadership also began to question the reliance on a Stalinist or big-push development strategy and attempted to reduce the rate of investment while giving greater priority to agriculture, light industry, and "nonproductive" investment, such as schools and housing. In short, the new leaders made a significant attempt to correct economic imbalances by rewarding consumers with a greater share of the pie and basing growth more on increases in productivity and efficiency than in the past.

The rejection of the utopian Maoist economic principles in favor of socialist principles more in keeping with China's level of development and the modification of the previous development strategy and priorities in favor of more consumerism and balanced growth would have significantly improved China's economy. Yet, these economic policy and strategy changes were bound to generate questions about institutional and systemic reform. The existing institutions and economic system had been developed specifically to implement the big-push, high-growth economic strategy and policies. However, the Soviet-type economic system is not well-suited for carrying out programs that promote consumerism, agricultural development, demand-oriented production, exports, infrastructure development, and technological innovation.

Thus, the Chinese economic reform program grew out of the early economic strategy and policy reforms and has gathered intensity as these initial reform moves encountered constraints imposed by the existing economic institutions and system. Since China's current economic reform program encompasses many changes, only a general survey of the major themes are presented here-enterprise ownership, decentralization, and the incentive mechanism.

Rather than all enterprises being state-owned and -managed, a mixed system of individual, private, cooperative, and state ownership is now accepted as consistent with socialism. Obviously, state ownership is to remain the dominant form of ownership in industry, 
but individuals are now allowed to create enterprises and hire workers, especially in the service trades. Cooperatives are encouraged in the trade, savings deposit, and food sectors as well as in workshop enterprises. In agriculture, land has been distributed to peasant households through long-term leases. Peasants can engage in single-crop farming, pursue sideline activities, or even leave their fields and move to local towns to work in the rural enterprises springing up all over China. Smallscale state enterprises, especially those suffering losses, are being leased out to private individuals and cooperatives who operate them for profit. Other state enterprises are raising funds by selling shares to workers who receive a fixed annual dividend or share of the profits.

To allow the various forms of ownership to play a significant role in the economy, it is now accepted that not all economic activities must be planned. Planning remains one of the key distinguishing features of China's socialist economy, but centralized planning and bureaucratically administered commands now cover a considerably reduced number of commodities. Some output outside the mandatory plan is included in guidance plans, which are given to lower-level authorities as a reference in determining production of commodities under their control. The production of commodities outside the mandatory plan and the guidance plans are determined by the production unit itself. State monopolies under the control of a central ministry are also being broken up to allow for greater decentralization and competition in production and trade, even foreign trade. Thus, the stifling constraints of planned targets and allocations are being reduced, many planning responsibilities are being transferred to lower levels of the bureaucracy, and market transactions between enterprises are being allowed.

These changes in ownership and enterprise functions have been accompanied with changes in incentives. Individual, private, and cooperative enterprises in both the rural and urban sectors are free to produce for the

\section{Figure 5.1 Changes in the Structure of China's Economy}

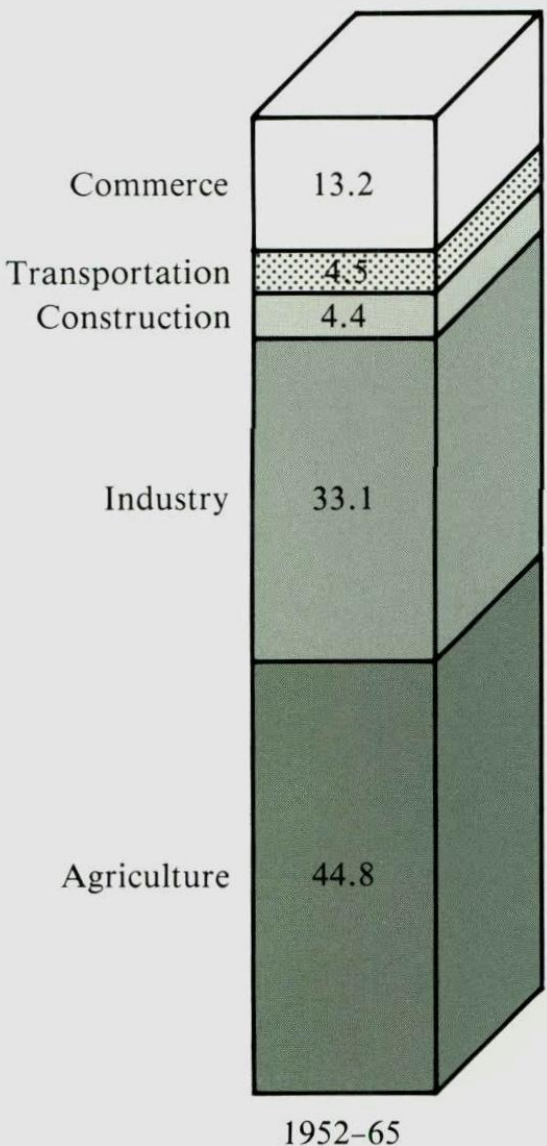

1952-65

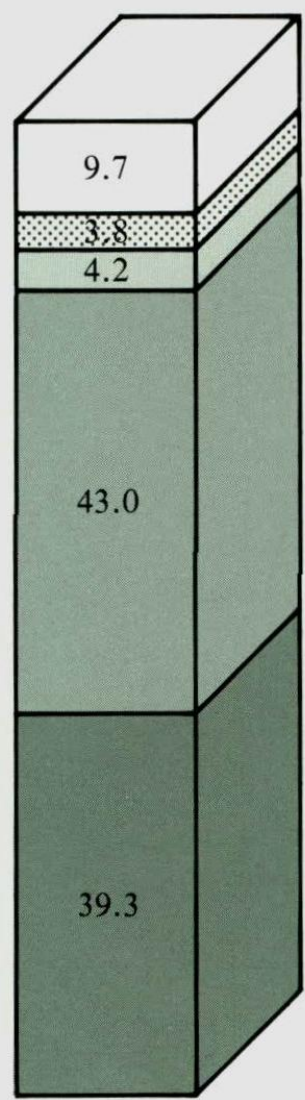

1966-78

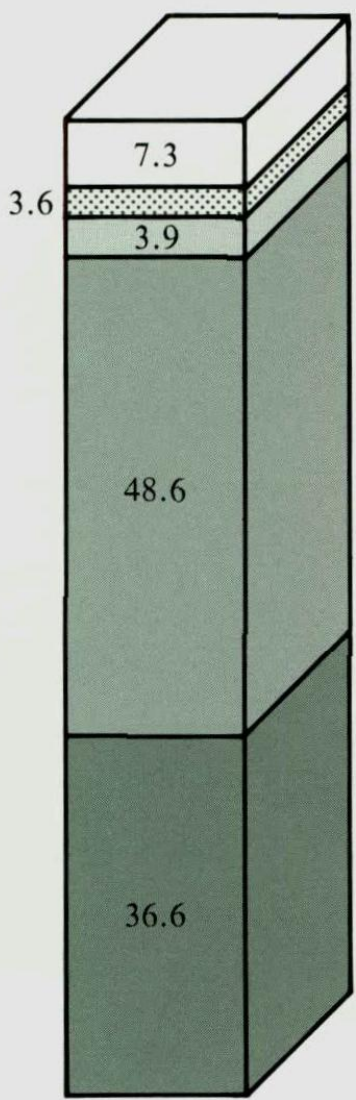

1979

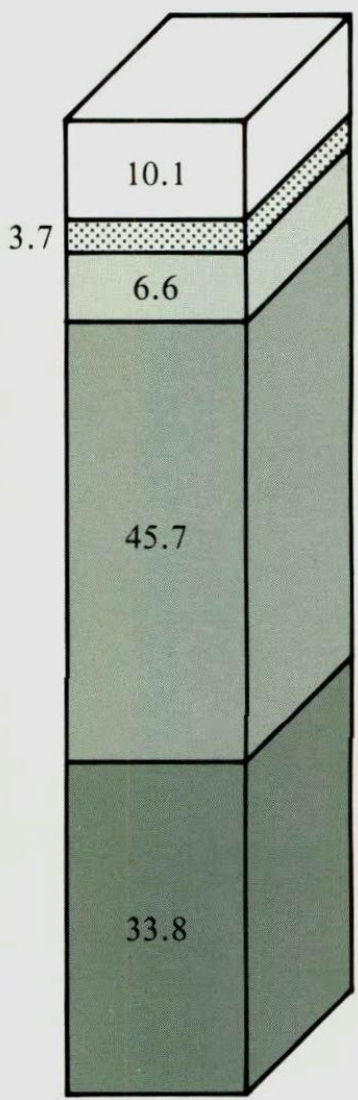

1987

Year

Source: State Statistical Bureau, Zhongguo Tongji Nianjian: 1988 (Statistical Yearbook of China), Beijing: Chinese Statistics Publishers, August, 1988. 
market and, after payment of business and commercial taxes, to retain and distribute the net profits. Enterprises operating within the state-planned sector are now allowed to keep their net profits, after payment of the business and commercial taxes and a new profits tax. Local government units are allowed to retain a share of the revenues they raise and the profits made by enterprises under their control. Fewer investment projects are now funded by unilateral budget grants from the central government; investment financing now relies more on funds raised by the enterprise and bank loans require interest payments and repayment of the principal.

In short, there has been considerable movement away from production and allocation decisions being made by planners at the top level of the economic bureaucracy and being implemented on the basis of administrative orders. China hopes to achieve a more productive and efficient economy with lower-level initiative and decisions based on economic levers or pricing, taxes, profits, and retained earnings. Furthermore, China's reform program has encouraged competition between the privately and collectively owned enterprises and the stateowned enterprises, and the market sector and the planned sector. The state enterprises and planned sector may be ahead in the competition, but they now monopolize very few areas. Thus, what began as a logical first step in adjusting economic strategy and policy for the sake of restoration and sustained growth has grown into a major economic reform program in search of a new economic system.

The outcome of this economic reform program is hard to predict. The reforms introduced thus far have created several economic problems and have encountered strong opposition in certain areas. They are not a magical remedy to all of China's economic ills. Yet, the evolution of the economic reform program in China over the past decade has been very impressive.

\section{Economic Performance Over the Past Decade}

The economic reform program that has already been introduced is widely accepted, largely because of its accomplishments. Economic conditions in China today are far better than they were a decade ago. Nevertheless, there is considerable debate over how fast reform should proceed. Many would like to pause and consolidate the gains already made before moving ahead. There are also those who are concerned over the economic problems that have resulted from the reforms and do not want to push on much further.

\section{Agricultural Sector}

The economic reform program was initiated in the agricultural sector, the major focus of concern at the Third Plenum in 1978. Greater material incentives to increase output and the removal of controls imposed by high-level bureaucrats eventually led to the restoration of household farming, specialization and commercialization in production and trade, and markets and market prices for most agricultural sector products. The rural economy flourished after 1978, with agricultural production increasing in real terms at an average annual rate of 6.6 percent from 1978 to 1986 . The largest increases in crop output were in the early years, resulting from the closing of the wide gap between potential and actual output created by the constraints and policies imposed on the peasants in the past. In more recent years, growth in the agricultural sector has been centered in sideline activities and rural industrial enterprises. Nonetheless, the rapid growth in the agricultural sector in the past decade has led to a significant reduction in imports of agricultural products, the elimination of rationing many basic foodstuffs to the urban population, and a richer variety and quality in the diet. This impressive record explains much of the momentum behind introducing the economic reforms on a wider basis.

\section{Industrial Sector}

Industrial sector reforms were started later and the initial gains were far less impressive. The major problem in agriculture was the need to remove controls to free the initiative of the peasants. In contrast, in industry the units of production were interdependent. Many were very inefficient and producing at a loss, thus requiring state subsidies. Some produced commodities that no one wanted. Therefore, in this sector decentralization and the creation of material incentives has been less effective and has been pursued more slowly. Land, capital, and labor are still largely allocated bureaucratically, and enterprise managers are not completely free to alter the composition of output and input to meet market demands and earn greater profits.

From 1978 to 1981 , industrial production grew slowly as enterprises, especially those in the machine-building and military industries, tried to get rid of inventories of unwanted goods and to produce goods in demand. After this initial period, however, local governments and enterprises used their retained funds to invest in local industrial projects, and as a result industrial production resumed its former position as the dominant growth sector. Between 1981 and 1986, the value of industrial output increased an average 13.6 percent a year. 
This rapid rate of industrial growth had its negative side. The demand for energy, transport, and building materials was greater than the increases in their supply. In addition, financial losses continued to be a serious problem in the industrial sector. Overall, the available statistics for the past decade do show significant increases in factor productivity in China's industry but somewhat slower increases in efficiency, and innovation and quality improvement continue to lag.

\section{Figure 5.2 China's Per Capita Consumption of Key Commodities}
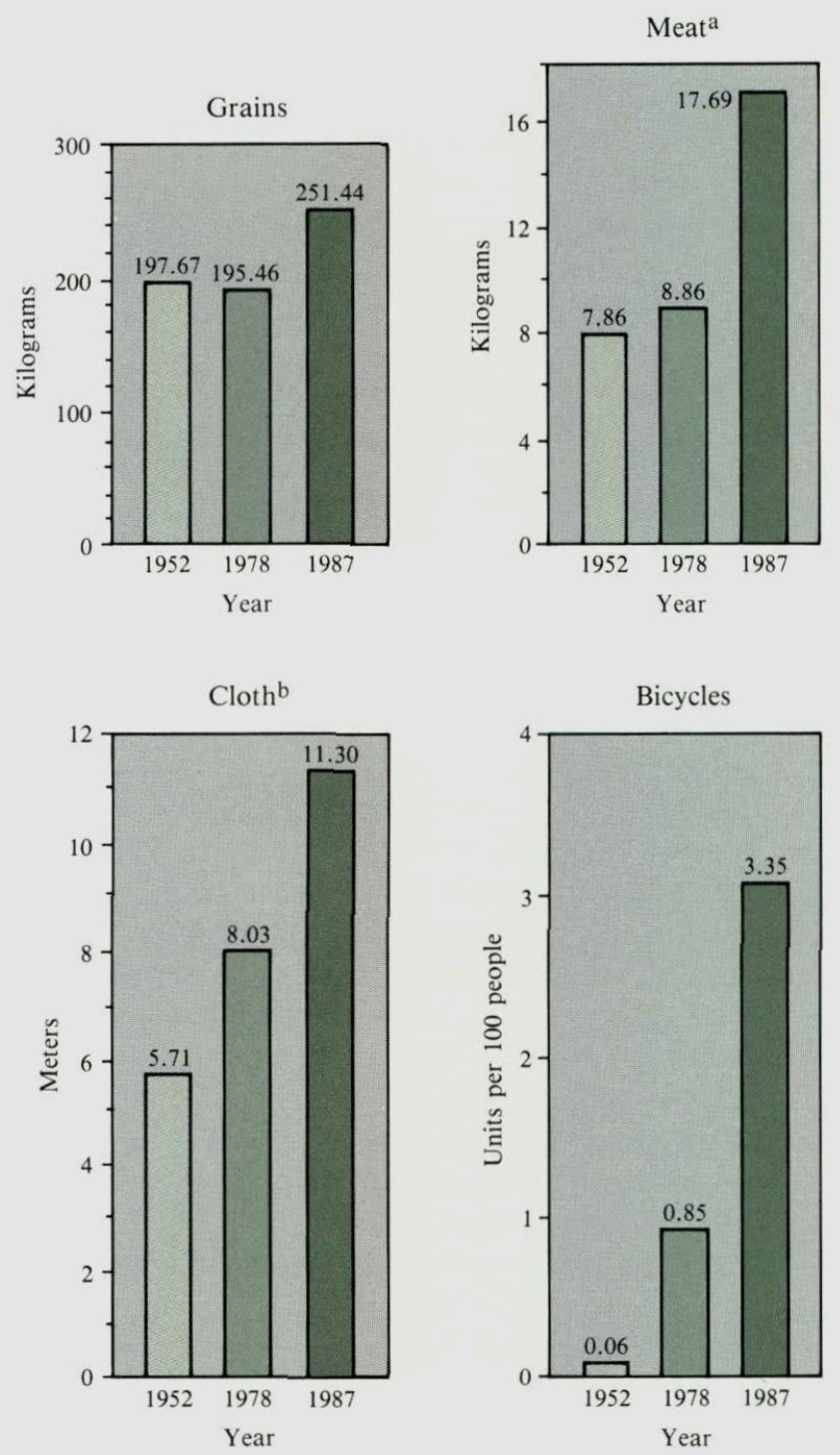

Notes:

a. Pork, beef, mutton, and chickens.

b. Cotton cloth, cotton/chemical blends, and chemical fabrics.

Source: State Statistical Bureau, Zhongguo Tongji Nianjian: 1988 (Statistical Yearbook of China), Beijing: Chinese Statistics Publishers, August, 1988.
However, it does appear that the downward trend in the growth rate has been turned around.

\section{Services Sector and Trade}

One of the biggest impacts of the economic reform program has been on the structure of the economy. Before 1978 , the services sector (finance, trade, and consumer services such as housing, entertainment, education, and restaurants) was reduced to a minimum. The neglect of this sector was a serious constraint on China's economic growth. In international trade, by the end of the 1970s the Chinese were finding themselves increasingly isolated from the rapid development of new products and technology in the developed world. In addition, the neglect of the foreign trade sector and reliance on exports of surplus commodities with ready foreign markets-raw materials, energy, and textilesmeant that China was losing its comparative advantage and becoming less competitive in foreign markets.

The economic reform program has recognized these past mistakes and now encourages the restoration and expansion of the services sector and trade. The results have been dramatic. Private and cooperative activity in the services sector has grown rapidly. Housing construction is taking place everywhere, and financial facilities are now available for the needs of individuals, cooperatives, and local enterprises and governments. In foreign trade, foreign entrepreneurs, businesses, and banks are encouraged to engage in joint and wholly foreign-owned direct investment and to provide loans for transferring modern technology to China. Special economic zones have been created where foreigners are given special tax and investment advantages, and many cities along the coast have been "opened" and allowed to provide their own deals to entice foreigners to invest in China.

Given the shortages and bottlenecks in China's economy, Chinese demands for imports are enormous; and whenever controls over foreign trade are relaxed, China's imports grow rapidly, much faster than exports. This tendency for import demand to exceed the available foreign exchange earnings is made worse by the overvaluation of the yuan. Thus, the opening of the Chinese economy to greater participation in the world economy has tended to have a ratchetlike effect: there have been periods of liberalization that first led to the very rapid growth of imports and deficits in the balance of commodity trade and then to the reimposition of direct controls over imports and the use of foreign exchange. Once an approximate balance in commodity trade was restored, a period of liberalization would be reintroduced that would set off another wave of im- 
port growth. Despite this ratchetlike growth, both imports and exports have increased very rapidly since 1978, much more than national income. China has changed from being a developing country with one of the lowest foreign trade dependency ratios in the world to being the largest foreign trader in the developing world with

\section{Box 5.1 China's Open-Door Policy}

Special Economic Zones (SEZs). To initiate China's drive for foreign trade and investment, in 1979 Chinese leaders set up four export processing zones called Special Economic Zones (SEZs). The SEZs, located in Guangdong province (Shenzhen, Zhuhai, and Shantou) and Fujian province (Xiamen), are aimed at attracting direct foreign investment in wholly owned or joint ventures to provide technology transfer and stimulate exports. Legislation to protect foreign investors and to stimulate foreign trade and investment has been implemented. Such legislation includes a patent law (April 1985), setting up arbitration offices to solve disputes on joint ventures, tax concessions, import duty exemptions, and access to the domestic market. Foreign banks can open branches in the SEZs and can make loans in both renminbi (the Chinese currency) and foreign currencies. Foreign banks are also allowed to make loan guarantees and investments within the zones.

Early in 1988, Hainan Island was made a province and declared the fifth SEZ. Hainan is viewed as an area where new experiments in administrative and economic reforms can be tried. Foreigners can lease lots of land on the island for up to 50 years and develop them as they see fit. Enterprises will be allowed to export local products that will be exempt from domestic quota restrictions, and foreign banks can set up local branches there. In addition, Hainan with all the advantages of the other SEZs will become almost a free port, or what the Chinese leadership hopes will be the "second Hong Kong."

Open Cities and Coastal Development. In April 1984, China targeted the coastal areas as a means to further encourage economic development and the open-door policy. Nearly a fifth of China's population lives in the coastal regions, and the people here include the best educated and most highly trained workers. Fourteen cities along the eastern seaboard of China were designated as open to foreign capital. The cities (Dalian, Qinhuangdao, Tianjin, Yantai, Qingdao, Ningbo, Nantong, Lianyungang, Shanghai, Wenzhou, Fuzhou, Guangzhou, Zhanjiang, and Beijing), although not having the same status as the SEZs, were permitted to establish "technical and economic districts" that would enjoy the same low taxation rate (15 percent) for projects involving foreign investment as do the SEZs.

By fall 1985, the Chinese government decided that cities would be open to foreign capital based on their ability to absorb the investment. Shanghai, Tianjin, Dalian, and Guangzhou were considered to be already experienced in attracting foreign investment and providing well-developed infrastructures and, therefore, were given priority support by the government.
In addition, three river deltas, one each in Guangdong's Pearl River area, Fujian's river triangle, and around Shanghai's Yangzi River, were designated economic zones in 1985. The purpose of these zones was to facilitate economic and technical cooperation within each area, thereby promoting horizontal and vertical integration of production within the zones. Since then, more and more cities and provinces have applied to open their jurisdictions to handle foreign trade and investment with the outside world.

Other Incentives. In October 1986, the State Council furthered its drive to attract foreign investment by promulgating new regulations for joint ventures or wholly owned foreign ventures that are engaged in export or technically advanced enterprises. These incentives include the following:

- Reduced tax rates for those enterprises using advanced technology or that are export producing and a 50 percent tax cut on income earned by foreigners living in China.

- Freedom in management decisions, including pay and recruiting and dismissing of staff.

- Tax-exempt enterprise profits that are remitted and reinvested.

- Exemption from the usual requirement of import licenses and duties on items used in export production.

- Ability for ventures with foreign investment to obtain hard currency by exporting Chinese goods not made by the venture itself or using renminbi to buy foreign exchange from ventures with surpluses.

- Priority access to infrastructure and allocations for production inputs for which the charge is no more than that for local state enterprises.

Additional incentives for foreign investment were announced in 1987, including in November of that year the approval of five trial centers to test the selling of land-use (lease) rights: Shanghai, Guangzhou, Shenzhen, Tianjin, and Hainan. Later Fuzhou and Xiamen were added to the list, and by the end of 1987 dozens of other cities announced their desire or intentions to sell land-use rights. Under the land-use rights, foreigners can lease plots of land ranging from 50 years (in Shanghai, Guangzhou, and Shenzhen) to 90 years (in Fuzhou) and develop the land as they see fit. Although the land is still legally owned by the state, transfer of mortgage, letting, and subletting are allowed, and the time limit can be extended. 
a foreign trade dependency ratio that is exceptionally high for a large continental country at any level of economic development.

China's imports (and exports) would grow even faster if China chose to accept the many loans offered at commercial rates. But the Chinese are very conservative and want to avoid any debt problems; they prefer the longterm official loans offered by foreign governments and international institutions at concessional rates. Direct foreign investment has grown, but foreigners remain somewhat cautious due to the many problems they have encountered: uncertainties in the implementation of the foreign investment regulations, undependable supplies of inputs and services, lack of access to foreign exchange, and the costs of doing business in China. The Chinese are trying to remove these obstacles as part of the economic reform program, but the rate of direct foreign investment in China still falls far short of China's needs.

\section{Change in Direction}

Foreign newspapers and popular journals that report on economic developments in China usually focus on the changes in the services sector. These reports all tend to indicate that China's economy has changed from the Soviet-style socialism of the 1970s to rampant capitalism today. Yet, these examples may only be representative of the direction of change being experienced in China today because private and collective market activities still represent a small share of total national income, and the services sector share of national income remains abnormally low, even for a socialist country with a Soviet-type economy. Turning around past trends in the structure of China's economy has been a major accomplishment of the economic reform program, but there is still a long way to go before China's economy will have the structure of a truly mixed system that is self-sustaining and provides balanced economic growth.

\section{Table 5.2 Foreign Trade and Investment (current US\$ billions)}

A. Foreign trade $^{\mathbf{a}}$

\begin{tabular}{|c|c|c|c|c|c|c|c|c|}
\hline Year & Exporis & $\begin{array}{c}\text { Rate of } \\
\text { growth } \\
(\%)\end{array}$ & Imports & $\begin{array}{l}\text { Rate of } \\
\text { growth } \\
(\%)\end{array}$ & & Balance & & $\begin{array}{l}s+\text { imports }) / \\
\text { nal income } \\
(\%)\end{array}$ \\
\hline $1966-78$ & 4.72 & 11.5 & 4.64 & 12.9 & & +0.08 & & 9 \\
\hline 1979 & 13.66 & 40.1 & 15.67 & 43.9 & & -2.01 & & 13.6 \\
\hline 1982 & 22.32 & 1.4 & 19.28 & -12.4 & & +3.04 & & 18.1 \\
\hline 1983 & 22.23 & -0.4 & 21.39 & 10.9 & & +0.84 & & 18.2 \\
\hline 1984 & 26.14 & 17.6 & 27.41 & 28.1 & & -1.27 & & 21.3 \\
\hline 1985 & 27.35 & 4.6 & 42.25 & 54.1 & & -14.90 & & 29.4 \\
\hline 1986 & 30.94 & 13.1 & 42.91 & 1.6 & & -11.97 & & 32.7 \\
\hline 1987 & 39.44 & 27.5 & 43.21 & 0.7 & & -3.77 & & 33.1 \\
\hline Total & 12.46 & 1.98 & 2.71 & 4.46 & 7.26 & & 8.45 & 37.50 \\
\hline $\begin{array}{l}\text { Loans } \\
\text { \% of Total }\end{array}$ & $\begin{array}{l}10.69 \\
85.8\end{array}$ & $\begin{array}{l}1.07 \\
54.0\end{array}$ & $\begin{array}{l}1.29 \\
47.6\end{array}$ & $\begin{array}{l}2.69 \\
60.3\end{array}$ & $\begin{array}{l}5.01 \\
69.0\end{array}$ & & $\begin{array}{l}5.81 \\
68.8\end{array}$ & $\begin{array}{r}26.55 \\
70.8\end{array}$ \\
\hline $\begin{array}{l}\text { Direct Investment } \\
\% \text { of Total }\end{array}$ & $\begin{array}{l}1.17 \\
9.4\end{array}$ & $\begin{array}{c}0.64 \\
32.3\end{array}$ & $\begin{array}{l}1.26 \\
46.5\end{array}$ & $\begin{array}{c}1.66 \\
37.2\end{array}$ & $\begin{array}{c}1.87 \\
25.8\end{array}$ & & $\begin{array}{c}2.31 \\
27.3\end{array}$ & $\begin{array}{c}8.91 \\
23.8\end{array}$ \\
\hline Other ${ }^{b}$ & 0.60 & 0.27 & 0.16 & 0.11 & 0.38 & & 0.33 & 2.04 \\
\hline$\%$ of Total & 4.8 & 13.6 & 5.9 & 2.5 & 5.2 & & 3.9 & 5.4 \\
\hline
\end{tabular}

Notes:

a. Foreign trade and investment figures are represented by annual averages.

b. Other $=$ Total $-($ Loans + Direct Investment $)$.

Source: State Statistical Bureau, Zhongguo Tongji Nianjian: 1988 (Statistical Yearbook of China), Beijing: Chinese Statistics Publishers, August, 1988. 
In summary, the major change in economic performance in China over the past decade has been in direction. The rate of growth for the economy may be only slightly higher than before, but it is far more stable than in the past, and the growth rates for the agriculture and services sectors are significantly higher. Consumers in both the rural and urban sectors have shared in the resulting growth far more than in the past, and per capita incomes and consumption levels are significantly higher than just a decade ago. Trade and services are being revived, and China has rejoined the world economy as a significant participant.

\section{The Chinese Economic System Today}

These trends in economic performance are very promising indicators for the future, but two basic questions remain: To what extent has the economic reform program created a new and different economic system in China and to what extent has it solved some of China's basic, long-term economic problems? Some observers have argued that China already is or soon will be a capitalist, market system or a market-socialist system, while others see the changes as relatively minor and temporary concessions in the face of economic necessity. The changes in China's basic economic institutions and policies, however, have been too significant and cumulative to be regarded as just temporary deviations from the traditional Soviet-type system. On the other hand, many of the most basic institutions remain in place with the role they had in the traditional system.

The four types of ownership-individual, private, cooperative, and state-exist in almost every sector of the economy, but the state sector dominates production for most sectors except agriculture. The mandatory, centrally planned targets also probably dominate economic activity in the state sector, although state enterprises also produce and trade above target output with other enterprises at negotiated prices or sell the surplus on the market at market prices. Almost all commodities are transacted at administered, negotiated, or market prices, and very few are produced and allocated completely within the state sector under mandatory plans. In the factor markets-capital, labor; and land-the erosion of the traditional means for allocating and pricing by the introduction of markets has, thus far, been very limited. In addition, the state's control over long-distance internal trade and foreign trade remains very strong and is readily reasserted with vigor whenever relaxation of that control leads to undesired results.
At no time in the past did the planners and central authorities exercise complete control over the allocation of resources and the production and distribution of goods and services. There always was considerable slippage between the plans and orders issued in Beijing and activities at the local level. Over the past decade, the economic reform program has significantly reduced the control of the central planners and enhanced the authority of local of ficials and cadre. More important, the present decentralization movement is accompanied by a serious attempt to remove some economic activity from the state and planned sectors altogether. This process of systemic change has progressed to the point where China's economic system can no longer be described as a centrally planned or Soviettype economic system.

On the other hand, China's leaders assert that they will not allow a capitalist, market economic system to return, and they appear to be serious in their efforts to seek a truly mixed system-a "socialist system with Chinese characteristics." Their present economic system does represent a mixed system, but one in which state-planned or -controlled economic activities still dominate, at least outside the agricultural sector. However, with the current direction of change, that dominance will probably erode further such that the mix will become more balanced. Thus, a rather lengthy period of unstable relations between the remaining elements of the traditional system and the elements of the expanding nonstate sectors may lie ahead.

A major issue that divides the leadership is how much further and how fast they should proceed to achieve a more balanced mix, that is, to reduce the role of the state and the centrally planned or controlled sector. A few general observations about the reform movement as it has unfolded in the past may be suggestive of the future. Much of the reform movement thus far has involved the removal of constraints imposed on the economy in the past, not the building of a new economic system. When instability or imbalances occur as a result of this liberalization, however, constraints and controls are reimposed. Acknowledging that the state-planned sector still dominates the industrial sector, some observers argue that by allowing and encouraging enterprises to engage in activity outside the plan, they will "grow" out of the state-planned system and create a new economic system. Yet, several fundamental economic reforms remain to be adopted for the economy to achieve that objective.

\section{Necessary Reforms}

Most Chinese leaders agree that price reform is needed for the economic reform program to really obtain the results desired. Yet, the existing price system deter- 
mines the distribution of income for individuals, units of production, and units of government; and any change will redistribute income, creating winners and losers. Thus, the Chinese have tried to introduce price reform on a marginal basis with small changes for a few items, giving subsidies to those who would be hurt. Although the Chinese leadership admits the need to reform the price system, it has continually stalled, postponed, temporized, and largely avoided this major step necessary for the creation of a new and efficient economic system.

A second fundamental area needing reform is factor markets. To facilitate the needed restructuring of the economy, it will be necessary to allow the mobility of factors creating production facilities in new areas and closing down some existing facilities. The function of factor markets in an economy is to mobilize land, labor, and capital and to allocate them toward their most profitable use and away from less productive uses. Despite all the economic reform policies introduced thus far, factor markets in China are not developed to any significant extent, and land, labor, and capital are still largely allocated by planning and administrative control.

For example, the central authorities have already lost considerable control over investment, but to create a market for the investable funds allocated on the basis of interest rates would institutionalize this loss of control and further erode their remaining control over investment. Thus, despite discussion and some moves in this direction, there is little indication that a fully functioning capital market will be created in the near future. As for the labor market, the state no longer guarantees everyone a job and urges people to find their own work in the collective, private, or individual sectors. Migration, however, is still controlled, and although these controls are not completely effective, they still considerably restrict the mobility of labor. Also, there is a rather narrow range in the wages in state enterprises. Again, the Chinese authorities admit the need to create a market for labor, relax controls over migration, and carry out wage reform in the state sector but have been very slow in implementing these changes.

Chinese leaders are also hesitant in allowing the logical implications of past reforms to be realized. Subsidies may be used to cushion the blow of the economic reforms on certain groups advantaged by the old system, but this practice generates expectations that any economic costs inflicted by the economic reform program will or should be made right by a subsidy from the state. Although state enterprises are to be responsible for their own profits and losses, enterprises suffering losses continue to receive subsidies, and few are forced into bankruptcy. Obviously these subsidies cannot be removed overnight, but the authorities could stop assuming the burden of new subsidies and move more quickly to reduce the magnitude of existing subsidies.

Having successfully removed many constraints on the economy and enterprise management, the Chinese authorities must develop the indirect levers they plan to rely on to control and guide the economy: effective monetary and fiscal policies. Again, they are well aware of the need for these indirect controls over the economy and have actively sought advice from those more experienced with them. Nonetheless, monetary and fiscal policy in China remains very poorly developed. In the absence of effective monetary and fiscal policies, inflationary pressures generated by the economic reform program are becoming serious. The resulting price inflation weakens support for the reforms and has become one of the greatest threats to the success of the economic reform program in China.

The past decade represents the successful first stage of economic reform, which largely consisted of removing constraints and prohibitions on the various economic agents. The reform of the price system, the creation of factor markets, the significant reduction of subsidies in consumption and production, the closing of unprofitable and inefficient enterprises, and the creation of effective monetary and fiscal policies remain as challenges for the Chinese reformers. These steps in the second stage of China's economic reform will require even more political courage and will than did the first stage and will not yield the instant success experienced in the first. Furthermore, the second stage will encounter significant opposition by those who lose as a result of these reforms, more so than was true during the first stage of the reform program. The record of the past year or so indicates the desire of China's leaders to press on but also reveals the difficulties they will encounter in doing so.

\section{The Solution of China's Fundamental Economic Problems}

No economy is without serious inefficiencies, many due to the ideological and political preferences of the society. Although China faces budget deficits, foreign exchange shortages, inflation, and probably the inability to sustain as high an average growth rate as over the past decade, its short-term growth potential has considerably improved. The Chinese probably can look forward to favorable economic development and growth over the coming decade or two. However, China's fundamental, long-term economic problems remain to be solved.

Future growth will differ from the growth of the past in a very significant way. The economic reform pro- 
gram encourages the development of growth nodes, areas that are capable of fast growth. The coastal regions will develop more rapidly and engage in foreign trade more than the interior regions, which are being developed as bases for raw material supplies and consumer goods industries. As a result of this change in strategy, coastal areas such as the Liaoning Peninsula, the Beijing-Tianjin region, the lower Yangzi river basin and Shanghai, and the Pearl River delta in Guangdong have experienced an economic boom. These regions can be expected to sustain fairly high levels of growth. However, this development will not "trickledown" to the approximately one-third of the population and two-thirds of the area of China outside the growth nodes until well into the future.

In the long run the Chinese face several other fundamental economic problems-agricultural development, employment opportunities, urbanization, and production of competitive products. The amount of arable land is limited, and it is being reduced as urban and industrial development spreads and major water control and hydroelectric projects are completed. Some economists believe the Chinese have already lost their comparative advantage in agricultural products and will need to rely on imports of agricultural products as China becomes a developed country. Even so, the Chinese still must make the transition to more productive scientific or modern farming, and this transition will take time, as the land area and agricultural population to undergo this transformation are very large.

As agricultural modernization takes place, it will free workers for noncrop activities. The Chinese already estimate that they have a surplus rural population of more than 100 million peasants. Thus, the nonagricultural and nonrural sectors of the economy must absorb labor on a tremendous scale well into the 21 st century. Part of this employment problem is that the surplus labor exists in areas where the alternative employment opportunities are the most difficult to provide. Urban centers along the coast will absorb some of the surplus workers, but that increase in employment could easily come from the growing urban population. What would resolve this problem is the development of an extensive network of urban centers of varying sizes, that is, the urbanization of China. The need to rebuild China's existing cities, modernize them, and develop new urban centers to keep pace with China's development will be a major drain on the resources available for development and cannot be accomplished overnight.

Since China opened its economy to acquire modern technology from abroad, the Chinese have needed to promote their exports to earn foreign exchange. To become truly competitive and win markets in the hard currency countries, the Chinese must make up for past mistakes or neglect in product quality, marketing, and product innovation-areas in which they are very weak. Competition among the developing countries in the import markets of the developed countries is intense, and China's current practice is to meet that competition through price cutting, a technique that works best in markets for homogeneous products such as raw materials and textiles. Where the demand is for quality, servicing and new products, this form of competition is not viable in the long run and threatens to give China a reputation as a cheap, but low-quality supplier.

These four major problems-agricultural development, employment creation, urbanization, and production of manufactured commodities competitive on the international market-are typical of the process of modernization and growth. Therefore, there is no reason to believe that China cannot become a major world economic power and developed economy in the long run. However, the question is to what extent has the economic reform program helped solve these problems or made them worse. A detailed analysis addressing this issue cannot be presented here, but it is worth noting that the reform program has been specifically designed to address China's short-term economic problems; and in several ways, it works to worsen China's long-term economic problems or, at least, delays their ultimate solution.

For example, the agricultural reforms may have restored individual incentives, but they also created small and scattered holdings and fewer large-scale operations. An alternative reform policy would have been to use one of the smaller collective units within the commune, such as the production team, as the basic unit of production and income distribution and to allow its members greater participation in decision making. The peasants, however, sought and were allowed to return to household farming. In the long run, it is likely that China's leaders will be forced to recognize that they may need a somewhat different institutional organization that involves larger units of production and that has responsibility for investment decisions and the maintenance of the rural infrastructure.

The economic reform program has yet to create a significant labor market to solve the long-term problem of providing employment opportunities. The options available to the large number of surplus workers in the rural areas, the urban unemployed, and those seeking alternative jobs are very limited, and many may find themselves underemployed in subsidiary, sideline activities or service tasks, or unemployed. Underemployment could well become a disguise for, rather than a longterm solution to, China's employment problem.

Much the same argument applies to the long-term development of a network of urban centers. The economic reform program urges surplus agricultural workers to find employment in nearby villages and towns, 
but this merely develops small-scale urban centers throughout the country that largely serve the local area. What is needed is the development of a rational urban hierarchy centered in the major urban centers of consumption and production that are the proven locations for growth of both population and income throughout Asia. The Chinese reformers, however, are concentrating on the development of medium-size cities and smaller towns where urban infrastructure costs, as well as the costs of commodity production, are probably much greater per unit of output than they are in the major urban centers.

The need to produce more efficiently manufactured goods of high quality that are competitive on the world market at reasonable prices is, in a way, the major objective of the whole economic reform program. A key force that could help to achieve this result is competition. The Chinese economic reform program, however, is trying to achieve this result largely through the incentive of higher retained profits, without seriously pursuing the enforcement mechanism of competition. Local authorities protect their local enterprises by preventing potential competitors from entering the local market area. If enterprises cannot meet the competition and operate at a loss, these losses are often subsidized by the local authorities. The Chinese authorities argue that after a given transition period, these subsidies and protection for inefficient suppliers will be removed. To date, however, the economic reforms have not been very vigorous in forcing enterprises to face the need to compete with alternative sources of supply, especially from foreigners. Thus, the pace of improved product quality and innovation, improved efficiency, and cost reduction is not among the more impressive results of the economic reform program. 


\section{CHAPTER SIX}

\section{Demographic and Social Change in China}

$\mathbf{N}$

o government in history has more actively intervened in population matters as has China in the past four decades, nor has any population policy been marked by such tremendous swings. From historically hostile to "Malthusian" birth control measures, China has embraced the most radical, yet successful, fertility control policies in the world. At the same time, the policy that restricted peasants to the land and successfully slowed the rate of urban growth has given way to the active encouragement of rural-to-urban migration. Together, the current policies of fertility control and rapid urbanization are producing a demographic revolution that has important implications for China's economy and social structure.

China's reversal in birth control policy developed both from the legacy of earlier demographic policies and the demands of the current economic restructuring. China has a large, young population with considerable growth "momentum" as a result of the lack of effective birth control policies in the 1950s and 1960s. Even at the current low fertility rate, China's population has a net growth of about 14 million per year. In the decade since the inception in 1979 of the policy that encourages one child per couple, China's population has increased by about 130 million, over one-half the

Chapter six was prepared by William Lavely, Visiting Fellow with the East-West Population Institute in 1987-88 and Associate Professor of International Studies and Sociology at the University of Washington. population of the United States. In the next two decades, China's population is likely to increase by another $\mathbf{2 0 0}$ million, assuming that the fertility rate continues downward.

These projections are particularly alarming to China's leaders because population growth will seriously complicate the introduction of their program of economic and political reforms. For a number of reasons, population growth placed few obvious strains on the economic institutions of Maoist China. The rural economy placed little demand on the state budget. The rural collectives absorbed new workers by continuously redividing the income and tasks, thereby providing a social and economic niche for all members. The relative stagnation of the rural economy and the thinly disguised unemployment were tolerable politically because the collective provided essential elements that legitimated Maoist rule: economic equality and a modicum of economic security. In other words, rural population growth could take care of itself, while the government diligently controlled the more burdensome task of urban population growth. This was accomplished through control of both urban fertility and rural-to-urban migration.

By contrast, the economic structures and political commitments of the reform period are quite unforgiving of population growth. In dismantling the rural collectives and replacing them with family-managed farms, the post-Mao reformers have placed economic growth and efficiency above equality as a prime virtue. The reformers, like other Asian government leaders, are staking their legitimacy on improved living standards 
and increased income per capita. Slower population growth is a common denominator of these goals.

The harsh one-child policy is a measure of the reformers' determination to limit population growth. Although falling considerably short of the one-child goal, the policy has successfully held the birth rate to low levels. But the policy's consequences can be expected to range far beyond the simple economic outcomes envisioned by its authors. Low fertility is creating a population revolution in China that should eventually alter prospects for employment, family structure, and welfare for the elderly.

The new economic strategy also implies large-scale population mobility. The government estimates that a large part of the rural labor force is underemployed, and this group is being encouraged to take jobs outside the agricultural sector. It is projected that the agricultural labor force will contract gradually and the nonagricultural labor force will nearly double by the year 2000. By then, it is projected that over one-half of China's population will be engaged in nonagricultural occupations.

The movement out of agriculture entails the creation of new jobs and massive movement of workers to cities and towns. Most of these migrants represent a new

\section{Table 6.1 Fertility Rates and Total} Population $^{\text {a }}$ for Selected Years

\begin{tabular}{ccc}
\hline Year & $\begin{array}{c}\text { Tola! } \\
\text { fertilisy rate }\end{array}$ & $\begin{array}{c}\text { Population } \\
\text { (millions) }\end{array}$ \\
\hline 1950 & 5.8 & 551.96 \\
1955 & 6.3 & 614.65 \\
1960 & 4.0 & 662.07 \\
1965 & 6.1 & 725.38 \\
1970 & 5.8 & 829.92 \\
1975 & 3.6 & 924.20 \\
1980 & 2.2 & 987.08 \\
1985 & 2.0 & $1,046.00$ \\
1986 & 2.3 & $1,061.00$ \\
1987 & 2.6 & $1,077.00^{*}$ \\
\hline
\end{tabular}

Notes:

a. Year-end.

b. The average number of children that a woman would bear during her lifetime at current childbearing rates. Figures have been rounded.

Estimated.

Sources: For the years 1950-81, Judith Banister, China's Changing Population (Stanford University Press, 1987). For 1981-86, Karen Hardee-Cleaveland and Judith Banister, "Family Planning in China: Recent Trends," Center for International Research, U.S. Bureau of the Census, CIR Staff Paper No. 40. For 1987, The Communique of Major Figures of the 1987 Nationwide, One-Percen Population Sample Survey by the Statistical Bureau of China, reported in ESCAP Population Headlines, No. 154, January 1988. "third category" of worker, distinguished from urban workers in the state sector and farmers by the fact that they enjoy neither the economic guarantees of state employment nor the security of the family farm. This growing class of the population lacks any guarantee of employment or safety net of social welfare. China's demography thus presents tremendous risks and challenges to those who must implement the new economic strategy.

\section{China's Demographic Transition}

China's leaders do not view China's population as a natural force, like the weather, to which they can only react. They are committed to the proposition that population growth and distribution, like economic output, can be planned and influenced by administrative means. This view may be in part a legacy of China's imperial history of state-sponsored migrations and elaborate mechanisms for the enumeration and the control of population. Their confidence in administrative intervention is no doubt reinforced by their success in recent decades in reducing mortality, controlling migration to urban areas, raising literacy levels, and developing policy to plan births.

The effects of government intervention are evident in the vital statistics of the past 35 years (table 6.1, figure 6.1). During this period, China experienced a demographic transition from high to low birth and death rates. The death rate fell rapidly in the $1950 \mathrm{~s}$, from about twenty per thousand in 1949 to eleven per thousand in 1958. The decline was punctuated by the threeyear (1959-61) famine that followed the Great Leap Forward campaign, which caused approximately $30 \mathrm{mil}$ lion deaths. After the famine, mortality resumed its downward trend and levelled off at a low of nine deaths per thousand in the 1970s.

The decline in the death rate is not unprecedented but is nonetheless unusual for such a large and poor population. This decline depended on the same imported public health technologies that have reduced mortality elsewhere in the Third World-improved sanitation and water supplies, pest control, and vaccination programs-but it was only accomplished by unusually high levels of government investment in public health and by harnessing China's vast administrative and organizational resources. Mass health education campaigns, an emphasis on public health and preventive medicine rather than curative medicine, and a large network of semiprofessional midwives and "barefoot doctors" were among the innovations that produced the decline. 
It is plausible that a mortality transition would have occurred in China with far less government intervention, but without it, it seems unlikely that the death rate would have declined so far or so fast. In 1981, the Chinese reached a life expectancy of 68 years, a level more typical of countries with three to four times China's per capita gross national product (GNP).

The decline of the death rate was rapid, but the decline of the birth rate has been spectacular. The crude birth rate fell from 33 per thousand in 1970 to 18 per thousand in 1979 , down nearly 50 percent in a decade. This is the fastest fertility decline on record for any large population, but it was exceeded by major subpopulations. For example, in rural Sichuan province, in the mid-1970s fertility declined 50 percent in just three years.

The causes of this decline are complex. One explanation points to China's record of rapid social change.
In other countries, declines in fertility have often been preceded by reductions in the death rate, increased levels of educational attainment, and other fundamental changes in family and economy. China had achieved all of these prerequisites. Mortality had declined, the rural economy had been reorganized through collectivization, and, in the process, considerable economic risk had been transferred from the family to the community. Moreover, education had moved deep into rural areas, and female illiteracy was on its way to being eradicated.

Although such developmental factors were probably important, the speed and character of the Chinese fertility decline argue strongly for the role of government intervention. Rising educational levels, for example, have had only a minor direct effect on the fertility decline. The fertility of illiterate women has also de-

\section{Figure 6.1 Crude Birth and Death Rates in China: 1950-87}

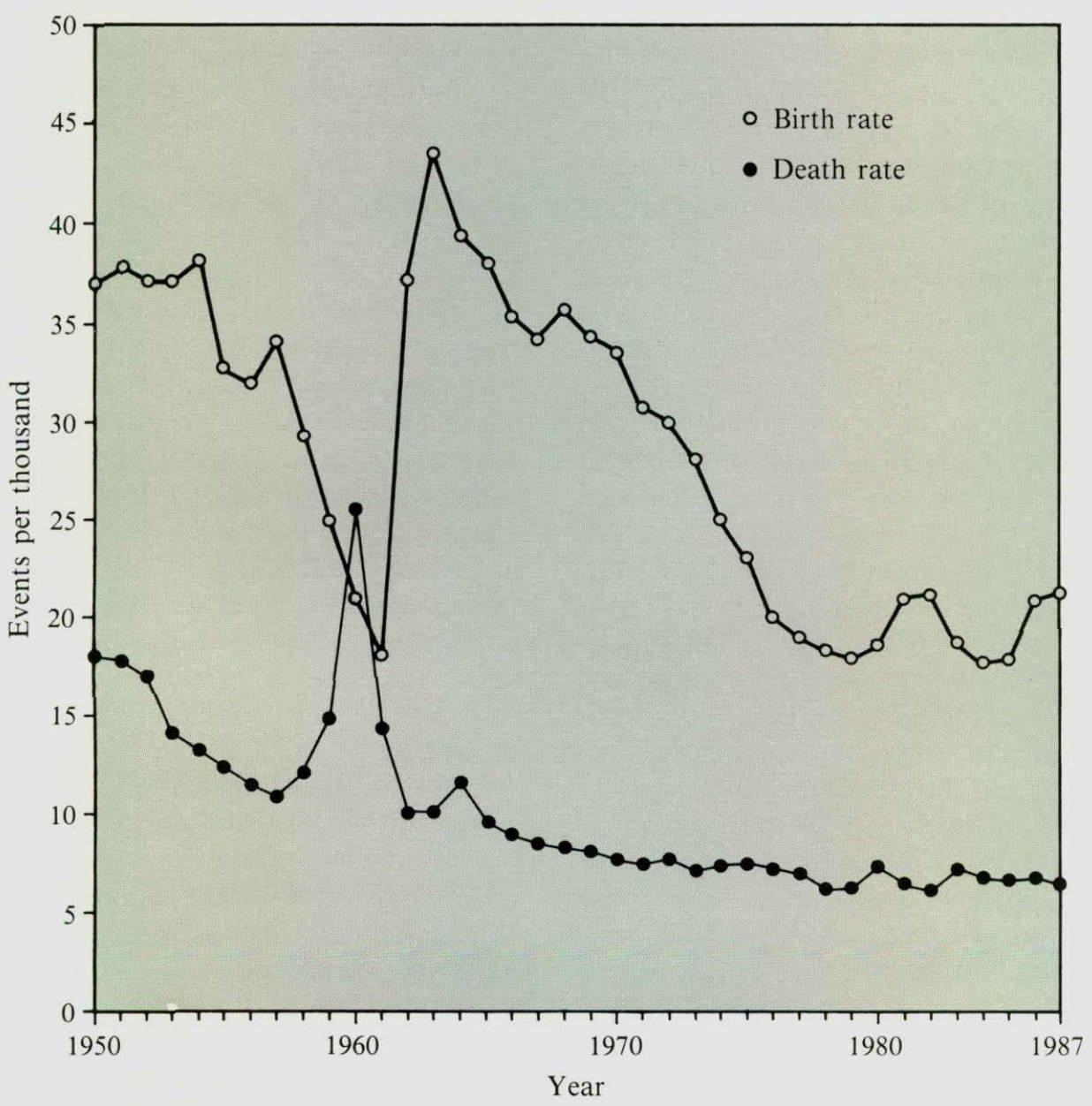

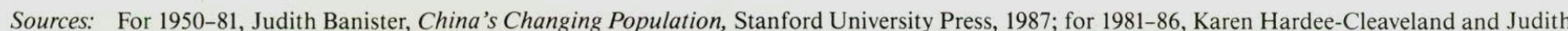

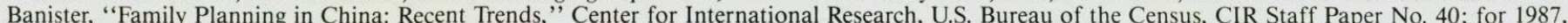

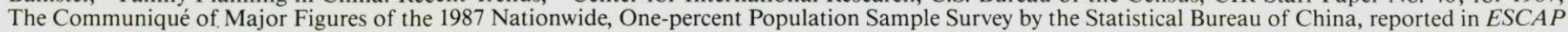
Population Headlines, No. 154, January 1988. 
clined spectacularly and virtually simultaneously with the better educated.

China's unique birth planning policies also suggest the role of government in the fertility decline. In 1970 China launched a policy of "late marriage, child spacing, and fewer children" (wan, xi, shao), a program that relied strongly on administrative intervention. Under the program, registrars declined to issue marriage licenses to couples below the government's suggested age for marriage, births in factories and rural communities were allocated annually according to quotas, and a network of birth-planning workers actively discouraged women from having more than two children. These efforts were apparently quite effective.

\section{Fertility Policy in the Post-Mao Era}

China's fertility control policy was radical by international standards, even in the early 1970s, the waning years of the Maoist era. In the post-Mao period, birth control became a top priority; and with the launching of the one-child-per-couple policy in 1979, China could clearly lay claim to the most radical family planning policy in the world. The policy was prompted by projections that even at two children per couple (replacement level fertility), China's population would continue to grow rapidly into the next century. Due to the high fertility rates of the past, particularly in the 1960s and early 1970 s, China's population had considerable growth momentum. About 180 million females were born in China between the end of the great famine and 1975 . If each of them gave birth to a single child by age 24 , this would add nearly 180 million births by 1999 . But, of course, no one expected them to stop at only one. These prospects threatened the reformers' plan to quadruple the per capita GNP by the end of the century. With the goal of holding China's population to 1.2 billion by the year 2000 and achieving zero population growth thereafter, they promulgated a policy in 1979 that could attain that goal: one child per couple.

The implementation of the policy draws on the powerful administrative resources available to the Chinese state. Particularly in cities, where most employees work in state enterprises, government officials use numerous administrative means to reward those who conform to the policy and punish those who do not. In theory, the policy depends on positive incentives to win compliance: couples signing a one-child pledge gain benefits, including longer maternity leave, wage supplements, and special school privileges for their single child. In practice, there is a far broader range of informal sanctions that can be brought to bear on those who resist the policy, involving access to housing, raises, and promotions. As a result, compliance in cities has been high. In the first three years of the program from 1979 to 1981,83 percent of the births in Chinese cities were first births, compared with 39 percent for rural births.

For a number of reasons, birth planning in rural areas had moved less steadily in the past decade. Most rural Chinese desire at least one son, a preference that makes a one-child family unacceptable to many. For some, this desire is motivated by the religious imperative to carry on the family line, but for others there are economic and social imperatives - a son is needed to manage the family farm and provide support in old age. Daughters are seen as less able to fulfill this role because they generally move to their husband's residence at marriage. The government's means of enforcement are also weaker in rural areas. Under decollectivization, many rural Chinese have become independent entrepreneurs, thus relatively impervious to economic sanctions. At the same time, the network of local cadres that formerly linked the central government to the peasant households has largely dissipated.

As a result, implementation of the one-child policy in rural areas has vacillated between draconian enforcement and relaxation. Mass sterilizations, IUD insertions, and coerced abortions have been used during times of rigid enforcement, particularly in 1983. However, there has been a policy shift toward moderation in recent years. National guidelines established in 1984 stressed that coercion must be avoided and set forth a number of exceptions to the one-child rule. A general slackening of birth-planning work ensued, and birth rates rose sharply. The total fertility rate rose from 2.1 in 1984 to 2.56 in 1987 , a 20 percent increase that has alarmed Chinese officials. The government is now sending mixed policy signals. Central Document No. 13 of 1986 stressed stricter enforcement of birth-planning policy, but in 1988 in a move that received little publicity, a number of provinces introduced rules permitting rural couples whose first child is a girl to have a second child.

It is difficult to measure the extent of voluntarism in the Chinese birth-planning program. A number of recent surveys suggest that rural Chinese couples have family size preferences ranging between two and three children, low for a poor agrarian society but still above the prescribed limit. To the extent that fertility is held at low levels involuntarily, the task of administering the birth-planning program is complicated. The program has concentrated on passive contraceptive methods. About half of the couples using contraception are sterilized, and another 40 percent use the IUD. Regulations and propaganda against "illegal"' IUD removal suggest that not all contraceptive use is voluntary. 
Although it is clear that coercion has been and is used, the birth-planning program is far from being monolithic in either goals or effectiveness. In the postcollective era, birth quotas have increasingly become the subject of "contracts" at various levels, with rewards and penalties linked to compliance. But rewards and penalties have often not had the desired effect. Many rural dwellers have chosen to pay fines to have their second child. A shortage of family planning personnel in many areas makes fines difficult to collect. Although the central government specifies the guiding policies of the birth-planning program, regulations and implementation vary by province. Within provinces fertility rates vary widely by locale, reflecting local conditions and variations in enforcement. Numerous groups are exempted from the one-child policy or given special treatment: ethnic minorities residing in remote areas, Han Chinese inhabiting hilly or mountainous hardship areas, couples whose single child has died or is diseased, and rural couples whose first child is a girl.

Chinese officials have clearly retreated from their ambitious goals of a few years ago. The one-child policy is now largely an urban phenomenon; in most rural areas, the actual policy is to maintain the rate at two children per couple. It now appears certain that the population will exceed the target of 1.2 billion by the year 2000 , and officials now speak of holding it to "around" instead of "within" that number. Still, the achievements of the birth-planning policy must be put in perspective-even the current total fertility rate of 2.5 children per women implies a level far below the norm for a nation of China's income. If fertility can be held at present levels, the Chinese fertility decline must be viewed as an unprecedented feat of social engineering.

\section{Migration and Urbanization}

The current movement of population out of agriculture marks one of the most momentous revolutions in China's modern history. Since the mid-1950s until recently, the Chinese government sought to keep the peasants on the land and to keep the urban portion of the total population from growing. The policy was quite successful; the urban population remained at roughly 20 percent of the total between 1960 and 1980 . However, in the past decade of reform, rapid urbanization has increased the urban population to roughly 40 percent of China's total population today, and continued growth is expected through the end of the century.

The term urbanization often conjures up an image of growth in cities, but much of China's "urban" growth is in an intermediate sector that is neither city nor farm. The urbanization trend is largely fueled by peasants who leave the land to ply trades in market centers in rural areas and by the redefinition of many of these centers as towns. While the change may not represent a shift to urban modernity for most, it nonetheless marks a rapid and momentous transition of an agricultural society toward a fundamentally nonagricultural way of life.

\section{The Maoists and Urbanization}

The Maoists had both ideological and practical reasons for controlling urban growth. They wished to build a new society free of the deviance and decadence that they thought typified Western cities. Their anti-urban bias was reinforced by the demands of the socialist dual economy established in the 1950s, which was divided between a state-owned urban sector and a collectively owned rural sector. Employees of the urban sector received their grain from the state and had to be paid from taxes levied on agriculture. Therefore, the urban population's drain on state coffers was a powerful incentive to limit its growth and raise its productivity.

This was accomplished in the 1950s and 1960s through the allocation of capital to heavy industry and through the direct manipulation of the demography of the cities. The state sought to purge the cities of unproductive personnel and to prevent rural-to-urban migration. To reduce the dependent population, birth control was advocated in the cities and housewives were urged to enter the industrial labor force. Many service jobs were eliminated, including entire job categories such as household domestics and pedicab drivers. Most important, steps were taken to prevent the influx of rural migrants to urban areas. The Household Registration Law of 1958 controlled population movements by making urban employment, housing, and grain rations contingent on bureaucratic approval. Migration control was supplemented by periodic state-sponsored rustications of urbanites to rural areas. A campaign against the service sector was also aimed at the Chinese countryside. Commerce in farm produce and other forms of entrepreneurship were sharply curtailed as the state established official organs for the movement of commodities and services. As a result, rural towns and marketing centers, once thriving centers of local trade, stagnated.

Although superficially successful, these policies carried a high price. By all accounts, Chinese cities were comparatively free of the crime and poverty typical of growing cities, and labor force participation rates and productivity were high by international standards. But because migration controls tied peasants to their local community, there were few mechanisms for the efficient allocation of labor. The agricultural sector thus remained mired in low productivity and inefficiency. 


\section{The Reformers and Urbanization}

In a sharp reversal of Maoist policy, the reformers have sought to increase agricultural productivity by encouraging excess labor to leave agriculture. Urbanization is actively promoted and perceived as inevitable. Thousands of new towns have been thrown open for rural migrants to pursue industrial and service occupations. The result has been a large-scale exodus from agriculture. Village markets and county towns, moribund in the Maoist era, now have the most dynamic and volatile populations in China. The number of towns has grown from 2,800 in 1982 to nearly 10,000 . Their aggregate population has grown from about 66 million in 1982 to over 200 million. Part of this growth is due to the redefinition of towns, but most of it is due to actual migration.

The new policy does not imply absolute freedom of movement or open labor markets. Chinese policy has emphasized the development of lower-level urban centers and still aims to prevent growth of major cities. A household registration system still regulates migration to cities, although less effectively than before. The slogan "leave the soil, but not the countryside"' (li tu, bu li xiang) expresses the intent that rural migrants should seek employment in local towns and not in major urban centers. But there is apparently dissent at the highest levels over how much migration to larger urban centers should be permitted.

Migration to major cities has clearly grown in recent years. The growth rate of China's major urban centers lags behind that of major Third World cities, but this is largely because of the low birth rate in Chinese cities. City populations are swollen by a substantial "floating population" of temporary migrants who lack permanent urban registration. Recent surveys indicate that the floating population makes up approximately 10 percent of the urban population of Beijing and Shanghai.

China's current urbanization is a large-scale transformation. A U.S. Census Bureau study projects China's urban proportion to rise from about 41 percent in 1988 to about 50 percent by the year 2000 . The world's largest and oldest agrarian state would thus become a predominately nonagricultural society.

\section{Consequences of Current Change}

The rapid fertility decline and the urbanization movement will influence China's demography for decades. This transformation of China's population will in turn affect employment, schooling, family relations, and old age welfare.

\section{Employment}

Two demographic facts overshadow the employment situation in China today and imply the need for millions of new jobs. First, the large youthful population, the legacy of past fertility, swells the yearly numbers of first-time job seekers far beyond the numbers retiring. Second, the population is moving out of agricultural occupations.

Under the assumption that urbanization will rise to 50 percent by the end of the century and that current labor force participation rates remain fixed, a recent U.S. Census Bureau study projects that in China between 1985 and 2000 , the number of rural workers will decline from 362 million to 333 million, while the urban work force will rise from 208 to 384 million, an 85 percent increase.

According to this projection, 176 million new urban jobs would need to be created between 1985 and 2000 . An economic reversal could slow the rate of urbanization because the movement out of agriculture is partly demand driven. If this demand should slacken, the rate of urbanization is likely to decrease as well. Some decrease in participation rates is also expected; female participation may decline as some women return to the roles of housewife and mother. But should the economic boom falter, high rates of urban unemployment could result.

Unemployment is a particular danger for the selfemployed entrepreneurs and tradesmen of the new towns, the third category of workers who lack the basic guarantees of jobs and housing enjoyed by state employees. As yet the new towns can provide little in the way of an economic safety net. The urbanization transition and the demographically driven demand for jobs thus contain the potential for hardship and unrest should China experience a recession.

The present period is critical because of the large number of people born in the late 1960s and early 1970s who are now reaching employment age. The pressure should diminish as the number of those born in the late 1970 s and reaching employment age in the early 1990s is smaller. China now has about 123 million people in the 15-19-year-old group. By 1995 this will fall sharply to 95 million and is projected to continue to decline gradually until it peaks again in 2010 , reflecting projected births in the early 1990s, an "echo" of the high fertility of the late 1960s. By the late 1990s, the problem of large annual numbers of first-time job seekers should stabilize.

\section{Dependency}

A large proportion of China's population is of working age because of the rapid fertility decline. Therefore, 
the age structure of China is now quite conducive to economic productivity and should remain so for at least two decades. If fertility remains low, however, China's population will age significantly early in the next century, and by the middle of the next century, China will have to adapt to a large elderly population.

The dependency ratio, defined as the ratio of population 0 to 14 years old and 65 and over to the population that is 15 to 64 years old, has fallen sharply in the past two decades. This ratio fell from 0.78 in 1970 to 0.53 in 1985, owing entirely to a reduction in the population under age 15. A projection, assuming a total fertility rate of 1.75 births per woman beginning in 1990 , shows the dependency ratio continuing to decline, from 0.44 in 1990 to a low of 0.36 in 2015, and then rising slightly. The easing of the dependency burden is entirely because of the smaller proportion of children in the population. The proportion of the population age 65 and over rises from 5.6 to 9.1 percent by 2015 .

Although the dependency ratio rises toward the middle of the next century, it never attains the levels that China experienced in the 1970s. However, the nature of dependency changes radically (figure 6.2). Whereas in 1970 the elderly accounted for one-tenth of the dependent population, in 2050 the elderly would account for more than half. By the year 2040, 21 percent of Chinese would be over age 65 . To put this in perspective, in the United States currently about 12 percent of the population is over age 65, and in Sweden, which has the world's highest share of senior citizens, about 18 percent is over age 65 .

This shift in China's age structure has a number of implications. By early in the next century, China's population will begin to resemble those of contemporary Eu-

Figure 6.2 Projection of Dependent Populations in China: 1970-2050

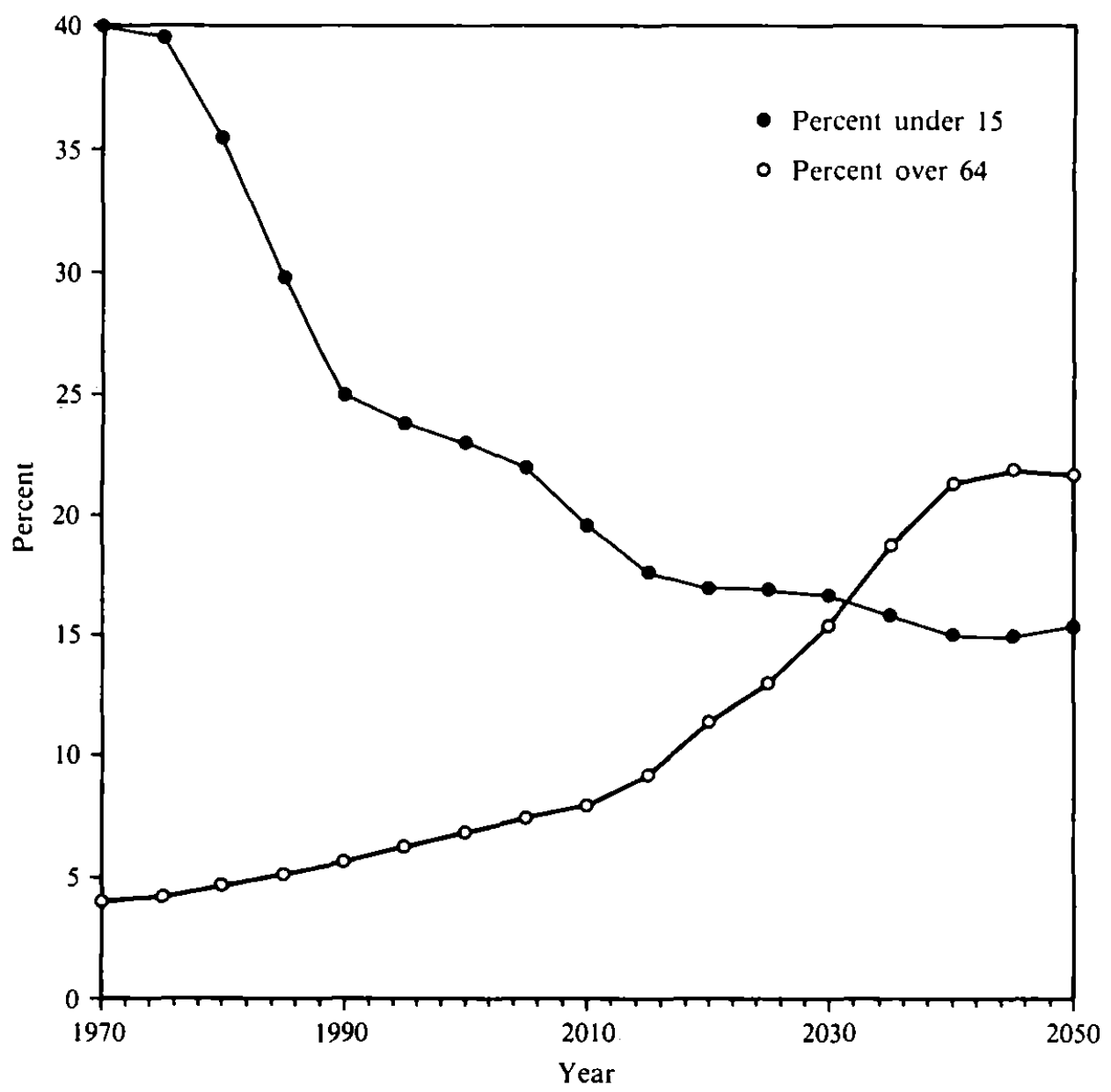

Source: Eduardo Arriaga and Judith Banister, “The Implications of China's Rapid Fertility Decline," Vol. 2, pp. 165-180, IUSSP, International Population Conference, Florence, 1985. 
rope. The number of people annually seeking jobs will become relatively small, and the labor market can be expected to tighten as the number of annual retirements begins to exceed the number of entrants. But an older age structure also has costs. The support of elderly dependents is far more expensive than for young dependents, and the returns to society are far less. As China's population ages, it can be expected to become more conservative and less innovative. In the coming decades, China will need to develop an extensive welfare apparatus to support and care for the retiring population and devote an increasing proportion of resources to this end.

\section{The Family}

China's population policies are having a profound influence on the family structure, family relations, and the status of women. Fertility declines change the family. Reduced fertility promotes equality between spouses. Freed of many of the child-rearing tasks that formerly occupied most of their married lives, women are free to devote themselves to economically productive pursuits that enhance their status within the family.

It is also plausible that lower fertility alters the relationship between parent and child. Fertility transitions generally mark a divide between a traditional and modern outlook on childbearing. As modernization brings reduced mortality and a more secure environment, children are seen less as an economic asset than as an end in themselves. And as the number of children declines from five or six to one or two, the parents become more able and willing to invest time and economic resources in their offspring. Couples who are limited to one or two children are likely to view these children differently than they would a larger brood, and fathers may be more likely to take an active role in their children's upbringing.

Smaller families thus hold the potential for substantial change in socialization and personality. Chinese children growing up in a traditional extended family learn their roles in relation to a hierarchy of siblings, cousins, and other kin; and group-oriented behavior and cooperation is learned early. The urban single child, by contrast, is generally the sole focus of parental attention. The implications for behavior and personality are uncertain. Popular reports in the Chinese press have stressed the negative aspects of one-child socialization, raising the possibility that the next generation of ' Chinese will be more individualistic and self-centered. But recent studies suggest that personality and academic achievement of single children are at least the equal of children with siblings.

In the long run, low fertility will simplify Chinese family and kinship. In urban China, where the singlechild family may be the norm for years to come, terms such as brother and sister will eventually be seldom used except among migrants from rural areas, and other terms for collateral relations, such as cousins and uncles, will also fall into disuse. The decline of collateral kin will paradoxically tend to focus family relations more on vertical, parent-child ties. Although welfare programs could assume the economic burdens of the retirees, parents may increasingly look to their single child for emotional sustenance in their old age. Many Chinese couples must adapt to a new vision of the future in which old-age security cannot be guaranteed by their children.

Decollectivization of agriculture has also influenced the family, but the effects are paradoxical. Kinsmen once tied to the same collective soil are now pursuing a variety of occupations far from their native village. At the same time, the reestablishment of the family household as the center of economic management and entrepreneurship is lending new solidarity to the family. These conflicting forces are producing a greater variety of family forms and relationships.

\section{The Prospects for Population Growth}

The legacy of the short-sighted pro-natalism of the 1950 s and 1960s poses a difficult dilemma for the Chinese people and their leaders-a classic case of conflict between public and private good. It may be quite rational for individuals to desire three or four children and feel that being limited to one or two is a costly hardship. But according to the macroeconomic calculations of China's leaders, free choice in reproductive matters would bring disaster. China's economic prospects, and, indeed, the shape and tenor of Chinese society in the next century, are crucially dependent on the outcome of current efforts to control fertility.

Should China's fertility control program continue to be successful, China's population could grow to between 1.4 and 1.6 billion in the year 2025. If the program breaks down and Chinese couples return to bearing an average of three to four children, as they did in the early 1970s, China's population could conceivably rise to over 2 billion by the year 2025 .

Consistency and continuity in fertility policy is one of the keys to future success. Since China's fertility levels are maintained through administrative pressure, there is the potential for a sudden and possibly disastrous "decompression." A number of recent surveys indicate that Chinese would prefer to have more children then they are now having. If just a quarter of China's women in their reproductive years gave birth in one year-a 
theoretical possibility despite China's high rates of sterilization-there would be 50 million births.

The economic reforms have complicated the task. By permitting peasants to become independent farmers and entrepreneurs, the reforms have possibly increased the value of children to some. More serious, though, is that the reforms have undermined enforcement of the fertility policy. The central government no longer has the far-reaching administrative apparatus that formerly linked it to the grassroots. Nearly one-third of Chinese villages lack a family-planning worker. Local leaders no longer have the array of administrative sanctions that were available under the collective. The greater mobility of the population is also a problem. The large floating population of people residing away from their legal residence has been able to reproduce with rela- tive impunity. Birth-planning policies are only just beginning to catch up with these developments. For example, new regulations that require temporary migrants to present family-planning documents when they depart their village and when they take jobs in urban areas are now in place.

Under the reformers, economic and social life has been liberalized to a very great degree. Reproduction is the only aspect of life that has actually become more restrictive than it was in the Maoist era. One might say that the government has purchased cooperation in family planning with other freedoms and affluence. By the same token, a reversal of economic fortunes could be the undoing of the fertility control program on which so much else depends. 


\section{CHAPTER SEVEN}

\section{Problems and Prospects for China's Mineral and Energy Industries}

$\mathbf{A}$

$s$ providers of raw materials and substantial foreign exchange earnings, China's mineral and energy industries are crucial to the country's economic development. Both industries have been undergoing enormous changes since the economic reform programs began in 1978. The pre-1978 period was characterized by a policy of self-reliance for minerals and energy, uncoordinated and imbalanced development of the two industries, and limited external trade. In contrast, after 1978 China looked to these two industries to be driving forces for the country's entry into the international economy. It actively sought foreign capital and entered into joint ventures to modernize and expand mineral and energy production and exports.

Despite successes in many areas, Chinese leaders have found the development of its mineral and energy production and exports to be an especially difficult challenge. In the past decade, three important changes in the country's mineral and energy outlook have affected Chinese policy. First, the Chinese have realized that despite China's rich resource endowments, growing domestic demand will absorb an increasing share of production and is causing China to become a major

Chapter seven was prepared by Allen L. Clark, Coordinator of the Minerals Policy Program, Resource Systems Institute, James Dorian, Project Fellow with the Minerals Policy Program, and David Fridley, Research Associate in the Energy Program, Resource Systems Institute, East-West Center. importer of some mineral products (table 7.1). Second, depressed demand and prices for many resources in world markets have made mineral and energy exports less attractive as earners of foreign exchange. Third, China's ability to expand supplies encountered serious difficulties. The exploration and development of offshore oil has been disappointing. Other constraints in the development and utilization of mineral and energy commodities include transportation bottlenecks, the inability to modernize existing facilities rapidly enough to expand production, and lower-than-expected jointventure investment in the mineral and energy sectors.

New policies and strategies are needed to encourage mineral and energy industry development. These activities will require large capital expenditures for exploration, development, and the modernization of processing facilities.

\section{China's Mineral Outlook}

Although a developing country, China, like some industrial countries including the United States, is both a producer and consumer of mineral products. It ranks first in the world in its known reserves of tungsten, tin, antimony, zinc, titanium, tantalum, lithium, and rare earths; and it is second in reserves of bauxite, nickel, mercury, molybdenum, and niobium.

The range of China's mineral production is illustrated by the fact that China Metallurgical Import and Ex- 
port Corporation offers more than 140 separate metal products for export. Despite this wide list of mineral products, only a few are of sufficient volume and value to have a major economic impact. One area where China's international importance as a supplier has grown is in strategic resources, including tantalum, tin, tungsten, and vanadium, which have rapidly increased over the years. China is the world's largest producer of tungsten and accounts for approximately 40 percent of world trade in tungsten concentrates.

Unique among China's mineral exports, in terms of importance to the industrialized nations, are the rare-

\section{Table 7.1 China's Mineral and Energy Trade: 1987 (US\$ millions)}

\begin{tabular}{|c|c|c|c|}
\hline $\begin{array}{l}\text { Commodity/ } \\
\text { Group }\end{array}$ & $\begin{array}{l}\text { Export } \\
\text { value }\end{array}$ & $\begin{array}{l}\text { Import } \\
\text { value }\end{array}$ & $\begin{array}{c}\text { Net export/ } \\
\text { (import) } \\
\text { value }\end{array}$ \\
\hline \multicolumn{4}{|l|}{ Minerals } \\
\hline $\begin{array}{l}\text { Crude minerals } \\
\text { and fertilizers }\end{array}$ & 362.0 & 28.2 & 333.8 \\
\hline $\begin{array}{l}\text { Manufactured } \\
\text { fertilizers }\end{array}$ & 12.0 & $1,402.5$ & $(1,390.5)$ \\
\hline $\begin{array}{l}\text { Metallic ores } \\
\text { and scrap }\end{array}$ & 285.0 & 525.2 & $(240.2)$ \\
\hline Metal manufactures & 797.7 & 515.2 & 282.5 \\
\hline $\begin{array}{l}\text { Nonmetallic mineral } \\
\text { manufaciures }\end{array}$ & 438.9 & 343.7 & 95.2 \\
\hline Iron and steel & 423.5 & $4,802.0$ & $(4,378.5)$ \\
\hline Nonferrous metals & 588.6 & 736.4 & $(147.8)$ \\
\hline Subiotal minerals & $2,907.7$ & $8,353.2$ & $(5,445.5)$ \\
\hline \multicolumn{4}{|l|}{ Energy } \\
\hline $\begin{array}{l}\text { Coal, coke and } \\
\text { briqueltes }\end{array}$ & 537.0 & 70.9 & 466.1 \\
\hline Crude oil & $3,146.0$ & 0.0 & $3,146.0$ \\
\hline Petroleum products & 861.9 & 397.5 & 464.4 \\
\hline $\begin{array}{l}\text { Gas, natural and } \\
\text { manufactured }\end{array}$ & 2.6 & 3.8 & $(1.2)$ \\
\hline Electricity & 2.9 & 68.0 & $(65.1)$ \\
\hline Subtotal energy & $4,550.4$ & 540.2 & $4,010.2$ \\
\hline $\begin{array}{c}\text { Total Minerals } \\
\text { and Energy }\end{array}$ & $7,458.1$ & $8,893.4$ & $(1,435,3)$ \\
\hline Total Trade & $39,541.5$ & $43,393.1$ & $(3,851.6)$ \\
\hline $\begin{array}{l}\text { Minerals and Energy } \\
\text { (\% of } \\
\text { total trade })\end{array}$ & 18.9 & 20.5 & \\
\hline
\end{tabular}

Figures are rounded.

Notes:

a. Major commodities and groups (by value) only.

Source: Economic Information Agency, April 1988, China's Customs Statistics, No. 1, Series 20, Hong Kong, 1988. earth metals such as lanthanum, cerium, neodymium, gadolinium, europium, dysprosium, and yttrium. These are essential to the world's petroleum, aerospace, telecommunications, computer, and rapidly evolving superconductivity industries. China's reserves of rare-earth metals are confirmed to be the largest in the world, estimated at $\mathbf{3 7}$ million metric tons or five times those of the rest of the world. China is at present the world's second largest producer of rare-earth metals after the United States, but since, unlike the United States, the domestic use of rare-earth metals has historically been very small, China rapidly became a primary supplier of these commodities to much of the world. It is likely to continue and increase this role in the 1990s.

Although China's policymakers realize that China cannot be self-sufficient in mineral products, they are concerned about the growth of imports. China has already become a major importer of iron, steel, copper, and aluminum - the basic metals required by an industrializing society. It is also a substantial importer of some nonmetals, including caustic soda, cement, fertilizer, industrial diamonds, soda ash, and sulfur. These imported commodities are of particular interest since they are basic requirements for agriculture, heavy industry, and light industry - the keystones of China's economic development.

By 1987, imports of major minerals reached approximately $\$ 8.4$ billion, a figure expected to rise through the end of the century. To slow the increased demand for imports, the Seventh Five-Year Plan (1986-90) envisions an increase in domestic production of aluminum, lead, and zinc, and modernization and revitalization of iron and steel production facilities. In the case of nonmetals, 6 new cement plants have been completed or are under construction, in addition to the 12 large fertilizer plants built in the 1970s and early 1980s, and 5 more plants are being built and 4 are planned. China's reserves and productive capacity of caustic soda, soda ash, and sulfur are also inadequate to meet present and projected demand, and several projects are under way to provide additional production capacity. Despite these efforts, China will remain a net importer of mineral products, particularly iron ore, aluminum, and copper, through the end of the century.

\section{China's Energy Outlook}

China has the world's largest known reserves of coal and hydropower and 2.6 percent of the world's known petroleum reserves. During the past 35 years, it has transformed its outdated energy industries to become the world's third largest producer of energy. 
Coal remains the backbone of China's energy economy. China is the second largest producer of coal and depends on it for about three-fourths of its primary energy supply. This share has dropped from the early 1950s when coal supplied 95 percent of final consumption but has increased from a low of 70 percent in 1976.

Oil, discovered in large quantities in the late 1950s and early 1960s, rapidly became an additional source of inexpensive industrial fuel and now supplies some 18 percent of China's energy needs. Natural gas production, concentrated largely in Sichuan province, has also grown and has fueled the industrialization of the Upper Yangzi region.

Although China has the world's largest hydropower resources, these resources are concentrated in the mountainous southwest part of the country, hundreds of miles from industrial centers. They have been left largely untapped and have never contributed more than 4.5 percent of total energy output.

Since 1980, China has been undergoing a radical reorganization of its domestic energy structure. China's energy industries were developed primarily as suppliers of inexpensive energy to industry. Diversification of the economy, increasing commodity exchange, and modernization of plant equipment, transport, and commerce have all contributed to changes in the structure of consumption. Oil, once used mainly as a boiler fuel, is now more valued for use in transportation and as petrochemical feedstocks. Oil-fired boilers are being converted to more efficient coal-fired boilers, and a ban was imposed on construction of new oil-fired power plants. To ease the severe pollution in the cities caused by coal use, a program was also initiated to supply gas to households. Liquefied petroleum gas (LPG) is now widely available in the major cities, and there are plans to supply the residents of the 10 largest cities with either natural gas or bottled LPG. Coal, which accounts for over one-third of railway transport volume in China, is now being developed in conjunction with mine-mouth power plants ("coal by wire") to supply power to consumption centers without an additional burden on the transport system. Similarly, nuclear plants are being constructed in coastal areas where either the lack of indigenous resources or the high cost of transport makes alternate fuels less attractive.

In contrast to nonfuel minerals, China is essentially self-sufficient in energy fuels and is an important exporter of coal, coke, crude oil, and refined petroleum products. Energy exports by 1985 earned over 25 percent of China's foreign exchange income. In 1986, however, as a result of the dramatic collapse of oil prices, China's potential foreign exchange earnings from oil exports fell by some $\$ 3$ to $\$ 3.5$ billion, equal to 15 percent of total exports (a drop in value equal to China's total export earnings in 1972). This massive price shift prompted China's leaders to reevaluate its oil export policy. They essentially decided that at the prices prevailing in 1986 ( $\$ 10$ to $\$ 15$ per barrel), oil could be more valuably used domestically and that future exports would be limited to about 27 to 28 million metric tons ( 540,000 to 560,000 barrels per day) annually.

Over the medium term, China hopes to counter the declining revenue from oil exports with higher levels of coal exports. In the past seven years, China has exported an average of 6 to 7 million metric tons of coal per year, less than 1 percent of total production. Coal is a major target for export promotion, and the Chinese hope to raise total exports from 13.5 million metric tons in 1987 to nearly 30 million metric tons in 1990. The price of coal, however, moves with the price of oil. With the depressed market for metallurgical and steam coal in the Asia-Pacific region, it is unlikely that 30 million metric tons of coal exports in 1990 would earn more than $\$ 1$ billion, or less than one-third the foreign exchange loss caused by the collapse of oil prices in 1986.

Energy use is growing rapidly with modernization. By 2000 , electricity consumption is expected to quadruple over the 1980 level, and oil consumption should grow by 175 percent. Coal use is slated to expand by 125 percent over 1980 , and natural gas use should triple.

Oil demand is likely to outstrip domestic supplies, returning China to a growing dependence on oil imports, last seen in the 1950s and early 1960s. The supply and demand for coal may be in rough balance, though a recent slowdown in output may presage a shortfall by the end of the century. Electricity, in chronic short supply throughout the 1980 s, accounts for the majority of investment in the energy industries. Even so, periodic brownouts and plant idling are expected through the early 1990 s and may continue for the rest of the century. As the foundation of economic activity, energy is of continuing and intense concern to China's policymakers; the success of the current modernization program will in large part depend on a stable and sufficient supply of energy.

\section{Problem Areas and Constraints of the Mineral and Energy Sectors}

China has developed a multifaceted program of mineral and energy development that is designed to substantially increase the production of many commodities for both internal consumption and export. Despite its efforts, however, China has struggled with a number of historical problem areas and constraints on development while adjusting to the open-door policy require- 


\section{Box 7.1 China's Transportation Problems}

With long distances between many of China's mineral and energy supplies and the industries that process or consume them, growth of these sectors requires an efficient transportation system. Because of a long period of underinvestment in this sector and rapidly increasing demand, serious bottlenecks have developed in the Chinese transportation system, constraining economic development. The problems Chinese manufacturing industries have had in getting timely supplies of energy and raw materials can usually be attributed to inefficient transportation rather than to absolute shortages.

The backbone of China's transportation system is its railroads, which account for two-thirds of total traffic. These were originally designed to service the development of heavy industry. Coal and timber account for over 40 percent of rail freight. Iron ore, cement, and chemical fertilizers also account for significant shares, but the expansion of manufacturing and light industry in recent years has changed the nature of transport demand. Finished and semiprocessed goods and foodstuffs now compete for space, and a more flexible system is needed to handle the requirements for the new, increasingly market-oriented economy. Passenger traffic has also grown rapidly.

\section{Box Figure 7.1}

\section{China's Transportation Usage}

Volume of Passenger Traffic

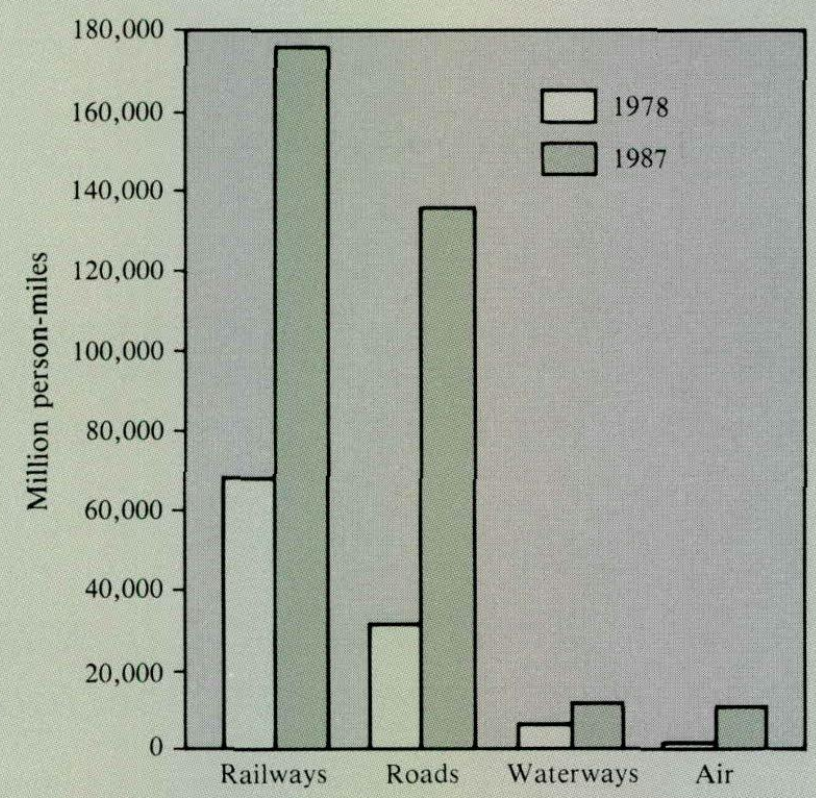

Investment in the transportation sector has been estimated at a low 1.1 percent of gross national product in recent years by the World Bank. To meet new needs, China hopes to invest $\$ 8$ billion annually in transport construction, using foreign assistance and investments. In 1988-89, China intends to replace or overhaul 5,000 miles of track, double-track 1,500 miles, and begin electrification of 2,200 miles of rail. By the end of the century, railroad mileage is to increase by 40 percent. China also plans to upgrade over 600,000 miles of roads and substantially improve port capacity, building 132 new berths by 1990. As in other countries, with modernization roads will take an increasingly larger share of the freight traffic. Domestic waterways and coastal shipping are at present lightly used compared to those in Japan. China hopes that recent action to break up the monopoly of the state-run Civil Aviation Administration of China $(C A A C)$ and create three new regional airlines will increase efficiency and improve the poor image of the airline industry. These smaller agencies remain state-run.

China's ability to develop a transportation system that will more effectively meet the needs of a rapidly growing and increasingly market-oriented economy remains a major economic challenge.

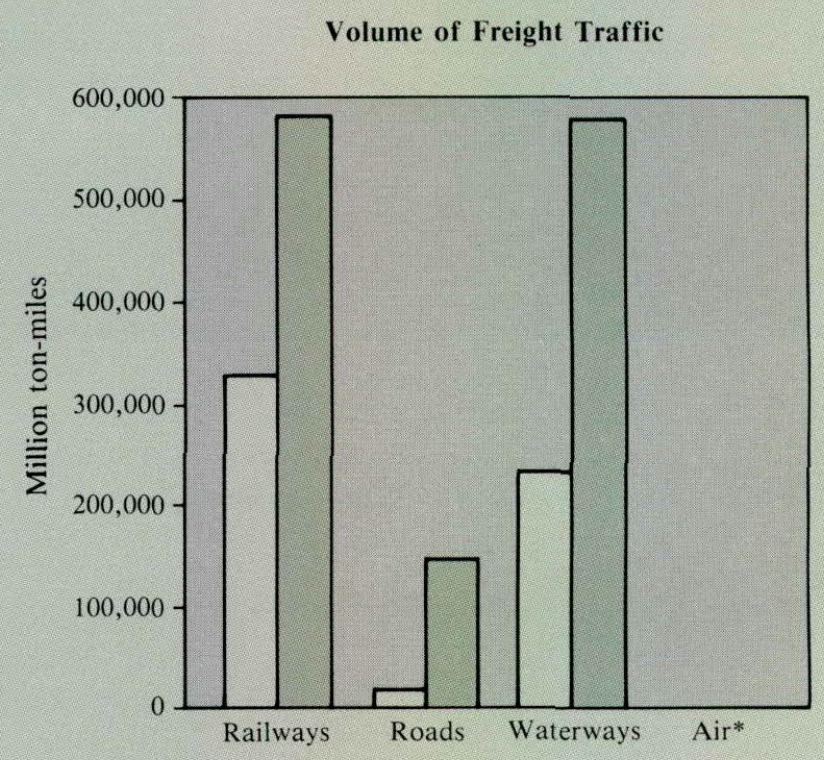

Note:

*Volume of air freight traffic in $1978=60$ million metric ton-miles; in 1987, 440 million metric ton-miles.

Source: State Statistical Bureau, China Statistics Abstract 1988, co-published by the China Statistical Information and Consultancy Service Center and China Statistical Publishing House, Beijing, 1988. 
ments to develop its mineral and energy resources. To a large extent, most of the major problem areas have been identified, and the central government continues to modify its development plans and legal and economic system in an attempt to resolve them. Three areas of critical concern are transport bottlenecks, the regulated pricing system, and the shortage of foreign investment in these industries.

\section{Transportation Problems}

Although China is well endowed in many major metallic, nonmetallic, and mineral fuel resources, many are located in remote areas, adding to exploration, development, and transportation costs. Moreover, many processing facilities for nonfuel minerals and oil and gas refineries are located away from either extracting or consuming centers.

For example, 85 percent of proven crude oil reserves in China are located in eastern China north of the Yangzi River, and most of the probable (but not proven) reserves are in north and northwest China. The principal energy-consuming regions of China are in the east, northeast, and south-central parts of China, typically distant from energy-producing centers. As supplies of crude oil grew, refining capacity expanded as well, nearly doubling since the 1970s. However, owing to interministerial rivalries and local pressures, most new refineries were placed far from oil fields or easy transport links. Consequently, oil-rich regions have excess refining capacity and oil-poor but politically influential regions enjoy large modern refining complexes.

The distances between producing, processing, and consuming centers would not be nearly the impediment that it is to mineral and energy development if China had a more modern and efficient transport system. In fact, the transportation of minerals and energy supplies places a heavy burden on an already overtaxed transport system. The lack of railway facilities has periodically halted increases in output at mines, particularly coal mines. Many mines in China determine their output target not on the basis of their productive capacity but on the basis of the transport facilities at their disposal.

Pipeline improvements have shifted some of the oil transport burden away from the rail system. Other efforts to relieve transportation problems have included the use of smaller coal mines away from major mining centers, but these are typically not large enough to operate efficiently and have lower quality deposits. More fundamentally, processing facilities should be sited according to economic rather than bureaucratic and political criteria. For example, as geological exploration efforts continue, nonfuel resource deposits are being discovered in western China. To avoid high transport costs, processing facilities should be located in this area and near energy resources such as hydropower, petroleum, or coal to facilitate energy-intensive smelting activities.

\section{The Pricing System}

China's economy suffers from imbalances in resource allocation because of an extensive but shrinking system of state-controlled prices and subsidies. For the most part, energy prices have remained fixed since the late 1950s. To encourage industrial development, industrial fuel prices were set artificially low while households and other users paid two to three times the industrial price. By the 1980s, this pricing scheme had resulted in serious imbalances and widespread waste in energy use. Effective utilization of industrial energy had declined to around 25 percent, nearly half the level in Japan.

Low prices for natural gas resulted in nearly one-third of the gas produced in some oil fields being flared. Low crude oil prices (in comparison to final product prices) encouraged the overbuilding of small refineries, many in provinces or localities far removed from sources of supply. High household electricity prices retarded the development of industries producing home appliances and electronics. Low-priced electricity to industry encouraged consumption and waste, resulting in increasingly tight supplies. High gasoline prices inhibited the development of highway transport. Much cheaper diesel prices prompted farmers to rely on diesel-fueled tractors and irrigation pumps; the resulting disproportionate growth in diesel demand led to a multi-billion-dollar program to upgrade the refineries to produce greater amounts of diesel fuel from the heavy Chinese crudes.

In 1983, China made some reforms by adopting multi-tiered pricing for energy and mineral products. This allows above-quota output from mines, refineries, and power plants to be sold at prices two to three times higher than the fixed state price. Although this measure has stimulated production of some energy and mineral commodities, problems with relative prices remain. Above-quota prices for gasoline, for example, are still 30 percent higher than diesel (on the international market, the gap is usually less than 10 percent), encouraging investment in gasoline-producing equipment in refineries to maximize profit.

More fundamental energy price reform has been repeatedly discussed, but little action has yet been taken. In view of the serious inflationary pressures arising from liberalization of the agricultural and industrial markets, China's leaders have been understandably reluctant to rationalize and raise energy prices, which they fear will result in higher prices in virtually every sector of the economy. Unless the distorted prices of mineral and 
energy products are addressed, however, it will be difficult for China to succeed in developing productive and efficient mineral and energy industries.

\section{Foreign Investment Constraints}

Investment from abroad will be needed to fund $\mathrm{min}$ eral and energy projects. During the $1986-90$ period, China is giving priority to foreign investment in, among other areas: (1) energy, including of fshore and onshore oil exploitation; coal development; nuclear, thermal, and hydropower stations and related equipment; and power transmission equipment, and (2) the raw materials industry; including nonferrous and ferrous mines, the metallurgical industry, processing industries, steel rolling, and new types of building materials.

It is uncertain, however, whether China will be able to attract the levels and kinds of foreign investment in minerals and energy that it desires. Major energy companies that had invested in the early 1980 s in oil exploration were generally disappointed with the results. Moreover, investments in the oil and mineral sectors suffer from the same general problems as other foreign investment in China. These include difficulties in obtaining foreign exchange to repatriate profits, rising costs of materials and wages, shortages and limited access to needed materials, inadequate infrastructure, bureaucratic red tape, and uncertainty about consistency in government policies and procedures.

\section{Issues in China's Asia-Pacific Role}

Because of China's open-door policies and the growth in its mineral and energy production and trade, China is playing an increasingly prominent regional role in these sectors. This role is one of both a major exporter (tungsten, tin, rare-earth oxides, oil, and coal) as well as that of a major importer of raw materials (iron ore, aluminum, copper, and several nonmetal commodities). China is also competing for international capital through borrowing or foreign investment to develop its indigenous resources. As China's participation in the mineral and energy economy of the Asia-Pacific region grows and changes in character, new issues arise that affect China's relations with its neighbors. Three important issues that are likely to grow in prominence in the 1990s are China's role as a competitor, China's potential role as an investor in regional resource de- velopment, and the political implications of mineral and energy trade for China's relations with its neighbors.

\section{China as a Competitor}

As China initiated policies after 1978 to sell mineral and energy products more aggressively and attract foreign investment, it was immediately regarded by other resource-exporting Asia-Pacific nations as a formidable competitor. The Indonesian government, for example, was deeply concerned and made strong representations to the Japanese that more competitively priced Chinese crude petroleum was displacing purchases of Indonesian crude in the Japanese market. The Association of Southeast Asian Nations (ASEAN) group as a whole expressed its concern to the Japanese government that its foreign assistance and loans to China should not come at the expense of the ASEAN countries.

China will continue to play a role as a competitor in important resource and investment areas. For example, as it seeks to replace declining foreign exchange revenues from petroleum with increased revenues from coal exports, its coal is competing directly with Australian coal. However, China's role as a competitor is changing in two important ways. First, with a growing demand that cannot be met by increased domestic supplies, it will be competing increasingly for access to foreign mineral and energy supplies. Second, in aspiring to capture the value added to resources by processing, it will be competing with both resource-rich countries that are also trying to establish processing industries and more advanced economies that have established processing industries.

The shift in China's position from an export competitor to a competitor for supplies is likely to be felt first in the petroleum industry. Within a decade, China's exports of crude petroleum and petroleum products may have declined to only a quarter to a third of its present level while its imports of petroleum products could increase dramatically. In particular, China is likely to become a major importer of diesel fuel in a regional market that is already very tight.

China's efforts to establish itself as a regional processing center may have an even greater impact. Chinese policymakers are aware that their country loses potential revenue and jobs by exporting raw materials rather than processed or refined products. For imported products, China can reduce its costs by importing raw materials and processing them at home. In some cases, China already has surplus processing capacity, in part because the processing facilities are located at uneconomical distances from supply sources in China. Moreover, with relatively low labor and energy costs, China 
may have comparative advantage in resource processing.

As part of its efforts to develop resource processing industries, China has adopted a "two ends out" (liangduan zai wai) policy of importing raw materials and exporting much of the product. For example, alumina is imported from Japan and processed into aluminum for export to Japan with retention of some of the import or export as partial payment for the processing. Similar activities are under way in both the copper and steel industries.

Unlike the metal and mineral industries where China's low labor costs provide comparative advantage, the energy-processing industries are highly capital intensive. China, therefore, is less likely to develop into a regional refining center. Although there have been a number of proposals to build export refineries on China's southeastern coast, the high cost of new refineries, in combination with low international oil prices, makes the economics of such projects highly questionable.

\section{Regional Investor}

As China's resource-consuming industries develop, China, like other industrialized or industrializing Asian countries, will seek to ensure security of raw material supplies abroad by investing in mining or processing industries. In a major step of this kind, the China International Trust and Investment Corporation (CITIC) invested \$120 million in the Portland Aluminium Smelter in Victoria, Australia, in 1986. This investment included a 10 percent equity participation and entitled China to 10 percent of the output. China is believed to have invested in the smelter to learn from both the smelting technology and managerial skills and to acquire semifinished alumina and finished aluminum, both of which are in short supply in China. China has also expressed interest in copper investments in Papua New Guinea. This would similarly allow China to acquire a claim over foreign resources for products in short supply in China.

Similar investments may occur in the petroleum industry for the same reason or to protect China's market share. For example, China responded to a tightening of U.S. lead standards that resulted in a loss of exports to the United States from China by investing directly in a refining and marketing company in California. Sinopec (China's national refining and petrochemical corporation) has bid on petrochemical projects in Malaysia to secure a claim on the products. If China becomes a net importer of crude petroleum because of increased demand at home, it may, like Japan, South Korea, or Taiwan, adopt a strategy of investing in overseas exploration and development activities.

\section{Trade with Japan, South Korea, Taiwan, and the Soviet Union}

China's mineral and energy trade may play a political role in helping improve China's relations with complementary economies. Sino-Japanese political relations in the 1970s and early 1980s were reinforced by the strong complementary needs of the two economies; Japan was interested in Chinese petroleum and coal and China needed Japanese capital goods, investment, and technology. In the late 1980s and 1990s, such economic ties could be a further stimulus for improvement in mainland China's evolving relations with the Soviet Union, South Korea, and Taiwan. China is a major producer of metals required by these neighboring economies.

For example, the Xinjiang Uighur Autonomous Region in northwest China and Heilongjiang province in the northeast are believed to be rich with minerals but have been poorly explored and developed. Both areas border the Soviet Union and have recently improved transportation corridors to the Soviet Union to facilitate cross-border trade. Mineral raw materials in these regions could be sold or bartered to the Soviet Union and perhaps processed more efficiently there than in China. The prospects for Sino-Soviet trade in energy resources are less favorable. Even if China becomes more interested in purchasing crude petroleum, Soviet crude generally has a high sulfur content. China would have to invest in expensive desulfurization equipment to use it. However, there are possibilities for border trade in energy resources in short supply locally.

South Korea and Taiwan, like Japan, are large markets for low-sulfur crudes, fuel oils, and coal. South Korea has already begun to import Chinese oil and coal, capturing the economies of the short delivery distance between the two countries. More political constraints exist in the case of Taiwan. With renewed emphasis in Taiwan on coal-fired power plants, especially with the shelving of its proposed fourth nuclear plant, coal imports to Taiwan have doubled in the past few years. In mid-1988, Occidental Petroleum proposed selling coal from its Antaibao mine to Taiwan, but Taiwan's leadership demurred "for the present time." Nevertheless, Taiwan recently permitted the indirect sale of raw materials from the mainland, and the first shipment of mainland coal arrived in October 1988. Taiwan and mainland Chinese officials are reported to have started discussions in Hong Kong over possible mainland oil sales to Taiwan.

As the South Korea and Taiwan currencies appreciate, these two economies will be seeking the cheapest possible sources of raw materials and processed inputs to maintain their competitiveness. Since China is a lowcost producer of such goods, neither South Korea nor 
Taiwan will be able to ignore the opportunities for increased trade with China.

\section{Future Prospects}

In comparison to other economies in Northeast AsiaJapan, South Korea, and Taiwan-China has a strong mineral and energy resource base. The use of these resources in international trade following the adoption of the open-door policies became a significant source of foreign exchange and also, in the petroleum sector, attracted a considerable degree of overseas investment. China's leaders, however, have discovered that China's resource supplies, in relation to its growing resource needs as an industrializing economy, are not inexhaust- ible. China is now in the process of adjusting from an economy perceived to be resource-rich relative to demand to one in which many resources are in short supply.

Like its neighboring economies, China's international economic future probably lies not in its export of raw materials but in its export of manufactured goods. As inputs, mineral and energy resources remain fundamental to rapid economic growth, but the emphasis has changed. China must depend on external supplies to meet a growing share of its resource needs. At the same time, given its resource base, China has a significant opportunity to strengthen its resource position by improving domestic performance in production, delivery, and efficient use of mineral and energy resources. The further development of its resource base in an economically efficient manner is a critical challenge for the future. 


\section{CHAPTER EIGHT}

\section{Environmental Problems and Economic Modernization}

\section{$\mathbf{C}$} threaten its ambitiou developing Asian countries, China's large rural population taxes land, water and forest resources, and urban growth outstrips the ability of authorities to provide adequate water and sanitation facilities. Land, water, and air will be further burdened by having to provide for a population that will increase by an estimated 170 million to a total of 1.25 billion people by the end of this century. The most critical new pressures on the environment, however, come from greater per capita use of resources as China seeks to achieve much higher standards of living. By accelerating economic growth and decentralizing decision-making powers, the post-1978 economic and political reforms potentially create new and more difficult environmental problems. At the same time, they promise to provide China with greater economic and institutional resources to cope with these problems.

There has been growing recognition in China of the magnitude of its environmental challenge. However, despite the commitment of China's leaders to sound resource management policies, continuing degradation of the environment suggests that existing-efforts are inadequate.

Chapter eight was prepared by James Nickum and John Dixon, Research Associates in the Environment and Policy Institute, East-West Center. It is based in part on a background paper by Professor Baruch Boxer, Chairman of the Department of Human Ecology at Rutgers University.

\section{The Historical Use of Resources}

The natural environment has played a central role in China's historical development into the world's most populous nation. China is regarded as the world's greatest example of a "hydraulic civilization," where a principal task of government is to regulate water. For centuries, Chinese governments have assumed responsibility for water and land management, both in the original Yellow River (Huang $\mathrm{He}$ ) heartland and, later, in the water-rich Yangzi River (Chang Jiang) regions, as they expanded their control south. Yet traditional China was no environmental utopia where man and nature lived in harmony. Forests, both north and south, were cleared for plowing. Floods were common along the Yellow, Yangzi, Pearl, Huai, and Hai rivers. The Yellow River periodically changed its course, bringing hardship to both those who were in its new path and those who had depended on its waters in its old location. Droughts could be even more devastating. When the rains failed, many starved, or migrated if they could.

Nonetheless, with over four thousand years of trial and error, the Chinese struck a tenuous balance in their traditional intensive agriculture. Recycled organic wastes sustained the fertility and structure of the soil. Fields and ponds were used together in a sophisticated way to provide grains and thatch, fish and fowl, hogs and silk. The cultivated area in the water-rich but mountainous south was expanded through intensive terracing. Irrigation augmented the supply of water during dry seasons and, in some cases, allowed a second or third crop. Most Chinese farmers owned at least part 
of the land they tilled, and markets for land, inputs, and products were highly developed.

Historically, Chinese culture maintained contradictory attitudes toward the natural environment. Confucians, who usually dominated the government, felt that natural forces, like society, should be made to behave properly. They contended, for example, that the dikes of the Yellow River should be built close to the main stream to guide it in the proper way. Daoists had a more empirical, inductive approach toward nature. Recognizing that a silt-laden river is prone to meander across

\section{Map 8.1}

\section{Important Physical Features of Eastern China}

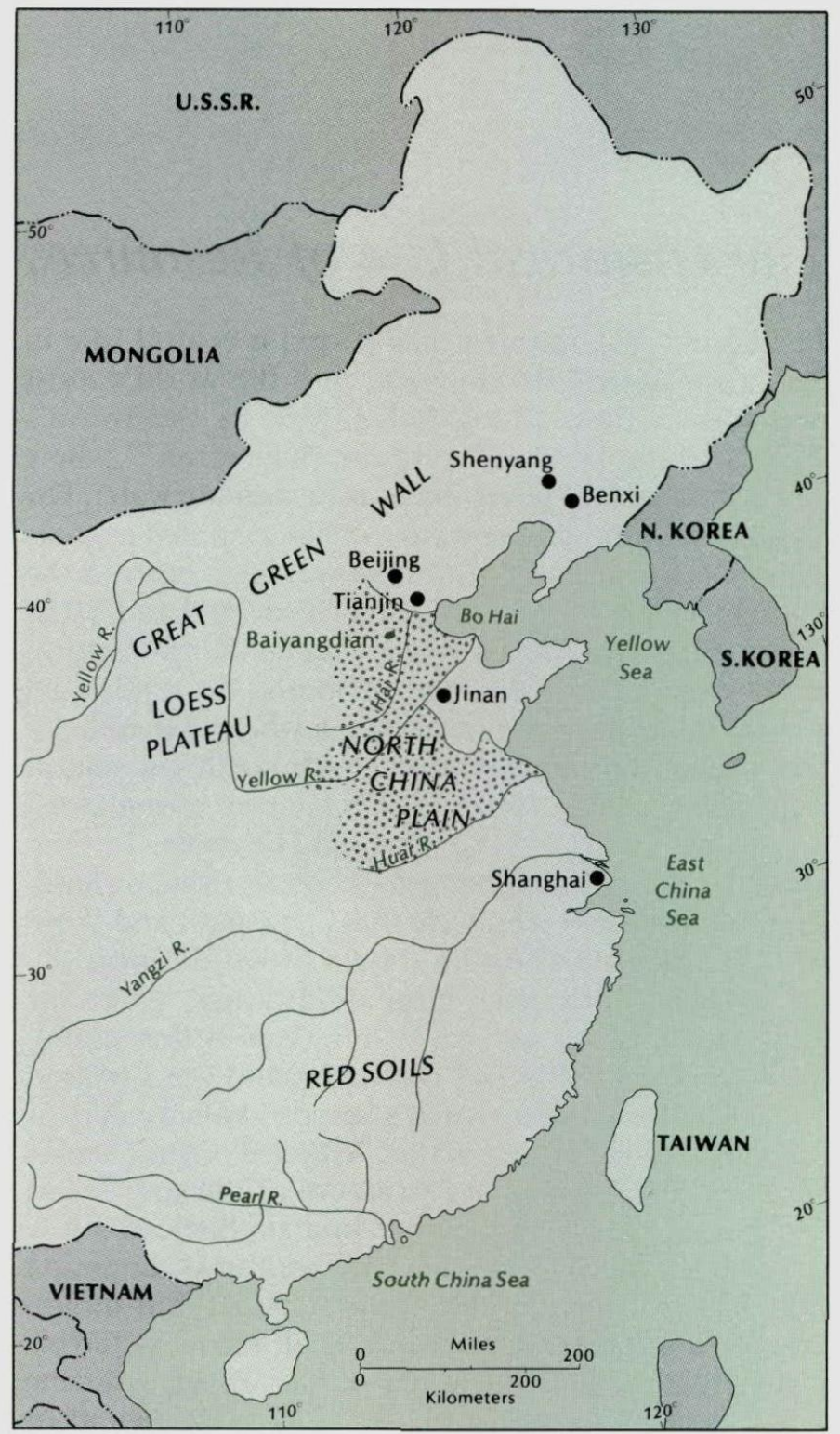

a flat plain and that restricting it too much would lead to disaster, they recommended that the dikes be set back some distance from the main stream.

The current philosophy reflects this traditional dichotomy. The first 25 years of post-1949 China were dominated by a Marxist Confucianism that was bent on harnessing nature and forcing it to adhere to the new proprieties of economic development and engineering science. Since the mid-1970s, there has been an increasing neo-Daoist recognition that nature's internal rules must be recognized and accommodated to ensure sound, sustainable economic and social development.

With the mistaken perception that the neo-Daoist view predominated, many outsiders watched China's early environmental protection efforts with much hope. It appeared that China's socialist society might succeed in making the difficult transition from a poor, agricultural base to economic and technological modernization by following principles that placed as much value on human welfare as on national economic growth. China seemed to offer a shining example of what might be achieved through materials recycling, soft energy development, and limits on urban growth.

The actual situation, however, was quite different. The emphasis on materials conservation, "multiple utilization," and recycling was more a reflection of shortages and the need for frugality than a response to altruistic concerns for the environment. In actuality, waste and environmental degradation were pervasive. There was an absence of specific environmental cleanup goals, and costs of environmental cleanup, repair, and management were seldom mentioned. In practice, production, then as now, was the primary objective.

The economic and political reforms of the past decade have changed many of the earlier government policies that had damaged the environment, such as the emphasis on local self-sufficiency in grain production. Rights over resources are increasingly better-defined, mitigating the previous overuse of common property. Environmental protection organizations and laws have been developed as well as a research and information base to support them. Nonetheless, the greater openness of the economy and the increased demands on the environment that economic growth brings have themselves created new burdens on China's renewable resource base. Furthermore, economic development and improvements in material standards of living, together with a greater ecological awareness, are increasing demands for improvements in the quality of the environment.

In most cases, it is difficult to document whether China's land, water, and air are more or less degraded than they were a decade ago. Many environmentally relevant 


\section{Box 8.1 China's Environmental Protection Organizations}

Like many other countries, China has established an impressive institutional apparatus to protect the environment. These efforts began as early as 1973 with the convening of the First National Conference on the Environment. This was followed by the establishment in 1974 of the Leading Group for Environmental Protection under the State Council and by the formation of counterpart environmental protection groups at the provincial level. By the mid1970s, the Leading Group had made substantial progress in linking national and local environmental agencies to carry out environmental surveys and monitoring and in planning scientific research agendas. Well-designed and effectively administered surveys assessed water, air, noise, soil, marine, and estuarine pollution; the effects of habitat destruction on endangered plant and animal species; regionand locality-specific environmental disease; and the condition of mountain, grassland, forest, and other ecosystems throughout the country. Several landmark studies in the mid-1970s explored the effect of pollution on human health and ecosystems in localized areas. Studies focused on industrial pollution in a reservoir northwest of Beijing; declining productivity from pesticide pollution in an important aquatic products base near Wuhan; and marine pollution in the Bo Hai, the shallow semienclosed sea bounded by Liaoning, Hebei, and Shandong provinces and Tianjin Municipality. The purpose of these scientific investigations was to provide a basis for environmental regulation and enforcement.

The historical Third Plenum of the 11th Central Committee of the Chinese Communist Party at the end of 1978 not only opened the way for economic reform but also for the first time recognized as a matter of policy the importance of environmental protection to modernization. The following year, the first comprehensive trial environ- mental protection law was passed by the State Council. The trial law provided the basis for a number of more specialized environmental laws in pollution control, natural resource conservation, and protection of the cultural environment (historical sites and nature preserves).

The earlier Leading Group was succeeded in 1984 by the National Environmental Protection Agency (NEPA), which is organizationally under both the Ministry of Urban and Rural Construction and Environmental Protection (MURCEP) and the Environmental Protection Commission of the State Council. NEPA guides and supervises environmental protection programs at all levels of the administrative hierarchy and drafts standards and regulations. Its research arm, the Chinese Research Academy of Environmental Sciences (CRAES), had been established earlier, in 1980, as the national center for environmental research and information. Regional institutes have also been set up in Guangzhou and Nanjing. In addition, the State Council environmental protection organizations play an important role in coordinating the activities of other ministries and bureaus. However, in so doing they face difficulties presented by their own structure, namely, the existence of two nominally separate environmental protection organs within the higher levels of the State Council. In practice, the same people staff both agencies, but it is doubtful that this confusion in the lines of authority and responsibility, common to Chinese organizations, enhances their effectiveness.

China's environmental management institutions, like their counterparts elsewhere in the world, have been handicapped by conflict with other goals (especially economic growth), inadequate funding and staffing, federal versus local conflicts, and problems in coordinating the efforts of a number of different governmental agencies. factors were not measured until recently, and some are still not measured. In other cases, such as the area under cultivation or the extent of deserts, statistics exist but are not very reliable.

Nonetheless, China's decisionmakers feel that progress to date in improving the environment has been inadequate. $\mathrm{Qu}$ Geping, director of the State Bureau of Environmental Protection, recently said that "atmospheric, noise, water, and soil pollution have not shown much improvement across the country over the past five years.",

Slower progress than desired in environmental management does not necessarily reflect negatively on China's environmental scientists, engineers, policymakers, and administrators. They are confronting a complex of problems with limited resources and only a few years of experience, as well as having to contend with ge- ographical conditions such as erosion that have plagued the Chinese people throughout their history. They are also up against a strong tradition of local autonomy that inhibits cooperation between administrative units and makes it very difficult for central agencies to supervise and enforce rules operating against the narrow economic interests of local producers. The planned economy has often reinforced this localism, carrying it to an extreme during the Cultural Revolution by insisting on local self-reliance while inhibiting market activities that could have led to more appropriate use of resources, notably land. Underlying these structural problems, however, is the need for China to make the transition from resource development that is predominantly extractive and supply side-oriented to resource development that focuses at least as much on conservation and demand-related factors. 


\section{Water Resources}

Water management has always been a key factor in China's economic development. Yet the uneven distribution of ground and surface water, the north-south imbalance in water supply and demand, and floods and droughts have for centuries challenged the ability of central and local authorities to provide flood control, maintain adequate food supplies, and provide for other basic human needs. China is consumed with water questions: store or disperse; build big dams or small ones; raise dikes or dredge channels; transfer water from surplus to deficit areas or improve the efficient use of existing supplies; reclaim lakes and marshes or leave them in a natural state.

In addition, serious concern about water quality, both surface and groundwater, is increasing. Raw sewage and industrial wastes are dumped into surface water, and agricultural return flow carries fertilizers and pesticides. One source estimates that over one trillion cubic feet of sewage is released into China's rivers each year, of which about half comes from 35 big cities. Only oneseventh of this is treated.

\section{Water Shortage: The North China Plain}

Problems concerning both the quantity and quality of water are particularly salient on the North China Plain. The distribution of water in China is very uneven: the Yangzi and other rivers in the south contain over 80 percent of China's total surface water but their basins include only about 37 percent of China's farmland. The remaining 20 percent of China's water is found in the areas north of the Yangzi. The water resources in these areas support almost two-thirds of all the arable land in China. Within this region, perhaps the most acute water problems occur on the North China Plain. The 120,000-square-mile expanse of this plain, home to 164 million people, is one of the most densely populated areas in the world. Most of its inhabitants work at tilling 50 million acres of farmland, about 18 percent of the national total. Agriculture and, increasingly, industry and urban life on the plain must contend with a natural water supply pattern that ill fits the requirements of human habitation. Drought is common in the spring and fall, and there is flooding in the summer.

Since the late 1940s the Chinese government has focused its efforts on providing the North China Plain with adequate irrigation and drainage, the latter to prevent soil salinization as well as floods. These efforts have been quite successful. Since the mid-1970s, however, the increased demand on local surface and subsurface water sources due to irrigation, urban-industrial development, and greater upstream use has raised serious questions about whether water will be a constraint on future economic growth or even permit maintaining current levels of production. In Hebei province, for example, where the water shortage is most acutely felt, 87 percent of the surface water is already being used. Overuse of groundwater has led to major drops in the water table in 30 places in Hebei, most of them near urban areas.

The quality of the surface water supply on the plain, never very high, has deteriorated considerably since the early 1970s with the expansion of urban, and more recently, rural industry. On the positive side, progress appears to have been made in reducing the area of productive land affected by salinization.

Possible solutions to the problems associated with water in the North China Plain can be summed up by the Chinese saying kai yuan jie liu, "open up new sources of supply and conserve what is already available." Supply increases have been the traditional response to growing water demands, but few new dam sites or untapped aquifers remain. Development upstream has also reduced water availability downstream.

A partial solution has been river diversions, most notably along the Yellow River, and from the Luan River to Tianjin. Major diversions from the Yangzi northward have long been discussed. Three major routes have been proposed, but the distances are far (over 500 miles) and the costs high (billions of dollars).

Groundwater sources offer little relief. Although some aquifers can still be developed, more often the problem is one of overexploitation, resulting in falling water tables, worsening water quality, and, in some cases, land subsidence.

Given the limited scope for development of new supplies, conservation has a major role to play. In the past, the cost of water to users was either low or virtually free. Not surprisingly, this encouraged the development of water-intensive production technologies and wasteful water use.

Agriculture, which currently uses 80 percent of the water on the North China Plain for irrigation, is where the greatest potential savings lie. A reduction of 10 percent in agricultural water use would provide at least 40 percent more water to other sectors of the economy. Using water more efficiently for existing crops will help, but a more fundamental reassessment of the entire pattern of agricultural production is needed. Recent decades have seen a major expansion of water-demanding wet rice and irrigated winter wheat and corn cultivation. In addition, growing incomes and urbanization have increased demands for other water-intensive agricultural products such as fruits and vegetables. It has become clear that it is no longer possible to have it allirrigated field crops, vegetables, orchards, fishponds- 
while also meeting growing urban and industrial demands for water.

Rapid social and industrial development in urban and, more recently, in rural areas have also increased demands for high-quality potable water. The major rehousing efforts of the past decade have led to dramatic increases in water use. For example, a family living in a traditional Beijing alley and sharing cooking and sanitary facilities may use about 10 gallons of water per capita per day, whereas residents of the recently built and omnipresent apartment houses use two to three times this amount. This increased water use is a direct result of improved living standards and is clearly desir- able, but it creates new urban water management challenges.

Government organizations are also major domestic water users. In part this is because they contain shower facilities and flush toilets for their large on-site resident populations and other staff and their dependents. Waste is still common, however, probably because the government pays the bill.

Industrial water use shares characteristics common to agriculture-wasteful product mixes and production technologies. The post-1949 emphasis on heavy industrialization and local self-reliance resulted in the creation of large, water-intensive industries in this region.

\section{Box 8.2 Water Use in Beijing and Tianjin}

Figures from 1982 indicate that 180 of China's 230 cities faced water shortages approaching 12 million tons a day, with total economic losses reaching $\$ 5.4$ billion $(20$ billion yuan) a year. More recently, scientists report that over 40 cities on the North China Plain, where the situation is especially critical, frequently face severe shortages of unpolluted water. Within the North China Plain, the problems of water management are notably salient along the northern edge where Beijing and Tianjin are located. These two municipalities have a combined population of over 17 million and include extensive rural areas. In both, water supplies are inadequate to meet water demands during certain periods in most years. But as demand grows with economic development, changing housing patterns and population growth, major shortfalls are expected. This prospect has promoted a series of studies on how to better manage the water resources of both cities. Since water supplies can be augmented only at great cost, these studies have focused on improved management of existing supplies and policies to reduce demand.

Agriculture is the major water-using and waterconsuming sector in Beijing and Tianjin. Irrigation accounts for over 60 percent of total withdrawals in both cities and a larger share of actual consumption because of evaporation. There is wide variation in the economic efficiency of water use. Irrigated rice and vegetables, for example, have similar annual water use rates; however, vegetables have a much higher market value than rice.

Industry accounts for 23 percent of total withdrawals in Beijing and 19 percent in Tianjin. There is a large potential for increasing the efficiency of water use, especially by reallocating water between industries. Beijing's chemical and metallurgical plants are heavy but not especially productive (or clean) users of water compared to many other industries. Although there is some scope for increasing efficiency by adopting technologies for reuse and recycling, water-inefficient industries may have to be phased out or relocated.

Municipal/domestic use, although a small portion of the present total use, is rapidly growing. Cooking and bathing are among the highest valued water uses. Nevertheless, there are other domestic uses of considerably lesser value, and there is considerable waste from leakage and misuse. Conservation of water for human use is especially valuable since that water has the highest cost and is of the best quality, yet comes at the very end of the supply system.

Water can also be better used if it is reallocated among sectors. Since agricultural uses tend to be of lower value and domestic uses tend to be of higher value, some transfer from agriculture to domestic use would seem to be called for. One hectare of irrigated vegetables or rice uses more water than 100 urban families. A reduction of 1 percent in agricultural use could supply 5 percent more water for household uses.

A joint Chinese and East-West Center study of the options for improved water resources management indicates that a combination of supply and demand management options would allow both municipalities to meet their water needs to the year 2000. Even that will not be easy, however. With a continuation of present policies, patterns of use, and technology, projected demand for water would greatly exceed the presently available supply by the year 2000. However, both Beijing and Tianjin can achieve a balance by increasing supply, improving the efficiency of water use, and reallocating water within and between sectors.

After the year 2000, the current direction and pace of economic development in Beijing and Tianjin will make it difficult to achieve a sustainable balance between water supply and water demand. If the Chinese change the pattern of their development, Beijing and Tianjin may continue to live within the presently available supplies of water. More likely, long-term development in the region will require new water supplies. It will then be necessary to consider additional transfers from adjacent basins, including the Yellow River. In any case, the era of cheap water has ended. 
Conservation is encouraged by a variety of methods, including regulation, metering, and pricing. Change comes slowly, however, especially when major capital investments have already been made in existing industrial facilities and the allowable rate of depreciation is very low.

China's authorities have responded to these immediate needs by rationing, escalating charges for abovequota use, and, in some cases, using expensive temporary water diversions. These measures offer only short-term solutions, however. A long-term answer requires consideration of more fundamental issues, including the transfer of water to higher-value uses.

Costly interbasin transfers of "surplus" water over long distances are a possibility, but in the medium term, and probably the long term as well, most portions of the North China Plain will have to rely on local groundwater and surface sources. As demand increases, reallocating both between and within economic sectors will become increasingly unavoidable. The central government will have to develop increasingly sophisticated policies to promote increased efficiency of use within each sector and to reallocate water among agricultural, industrial, and urban nonindustrial users.

For those policies to work effectively, institutional reforms will be necessary. As China makes the difficult transition from a closed, nonmarket command economy to a more open, market-oriented one, numerous institutional changes must follow, similar to those affecting land. Water, as a quasi-open access resource, poses major practical and theoretical questions in terms of planning and reliance on the market to improve allocation, such as: Who owns water? How can claims to water be transferred? Can farmers in effect "sell" water to other users, or are they to continue to lose it by fiat? Can industrial enterprises continue to vie with each other to pump aquifers dry? Can they buy or sell water as need dictates? It is particularly important for China to address these questions now, while new rules are still being formulated and put into effect.

\section{Land Management}

Supply-oriented policies that focus on increasing resource use without regard to efficiency are even less likely to solve China's main problems of land management: soil and soil fertility loss, decline in farmland, and urban waste disposal. In fact, an exclusively supply-oriented management approach is almost certain to exacerbate these problems.

Although China ranks after the Soviet Union and Canada in total land area, it contains very little usable "idle" land, and the proportion that is being used is threatened by natural and human processes. Soil erosion, always a problem in the north, has become a major problem in the south, owing in part to the opening up of land on fragile slopes and to the stripping of trees and grass cover for timber and fuel. Deserts are encroaching on farmland and pasture in northern and western China. In the developed areas of the country, land-use growth in one area translates almost directly into a reduction somewhere else. For example, as cities grow and rural industry expands, some of China's best farmland is being lost. Some experts contend the trend may be irreversible. A related problem that is becoming very serious is the breakdown in the traditional symbiosis between city and farm where urban organic wastes provided fertilizer for the agricultural green belts surrounding most cities. Changes in fertilization practices, owing in part to agricultural intensification to make up for the loss of land, and a decline in the quality of urban wastes have led to a serious disposal problem for the waste solids and liquids of China's cities. The shift toward greater dumping of untreated wastes on common lands and in common waters has had some significant, sometimes dramatic, adverse effects on human health.

\section{Soil Erosion}

Soil erosion has long been a problem in north China. Some historians believe that the great semiarid Loess Plateau of north-central China was once covered with trees and grass, but that a combination of climatic change and prolonged human occupation stripped it of its natural protection. It is doubtful that it was ever free of erosion, however. The North China Plain consists primarily of loessial soil. carried down from the Loess Plateau over thousands of years by the Yellow River. The Yellow River, cradle of China's civilization, carries nearly half the combined silt load of all the world's rivers. Left alone, the silt that it deposits on the plain would fill in its present riverbed, causing the river to change course. To prevent this, the Chinese have built dikes to contain the river and its silt. As the riverbed rises due to silt deposition, the dikes are raised and reinforced. Eventually the river will win the battle and change course; however, the current dike system holding the riverbed several meters above the North China Plain will, according to experts, adequately restrain the river for the next century.

It is generally recognized that the solution to the silt problem lies more in slope stabilization in the Loess Plateau that straddles the middle reaches of the Yellow River than in downstream dike control. Some areas have been successful in controlling soil erosion, but in most of the region there has been no change or further degradation. In recent years, an attempt has been 
made to strengthen farmer involvement and responsibility. Nearly two-fifths of farming households in the Loess Plateau have been assigned soil conservation responsibilities for specific plots of erosion-prone land. The results have been mixed, as in many cases the farmers have neither time nor money to plant trees or grass.

Soil erosion is no longer primarily a northern problem. In the past thirty years, the southern province of Jiangxi, which was once essentially free of erosion, has seen a quarter of its land become affected. During the same period, erosion in the Yangzi River valley doubled the silt discharge of the main stream to 550 million tons a year, fourth among world rivers. The World Bank and other organizations are seeking to stabilize the lateritic red soils on the southern tributaries of the middle and lower Yangzi River valley, and the Ministry of Water Resources has recently embarked on a modest 12 -year, $\$ 135$ million (500 million yuan) project to stabilize the upper reaches by planting forests, changing the cropping patterns, and developing alternative energy sources to firewood and grass.

In rural areas, household fuel needs contribute to deforestation and the overcutting of grasses and shrubs. The burning of these fuels also presents a serious indoor health hazard. The well-publicized generation of biogas has been limited to areas of southern China because of its warm climate and ample supplies of organic waste materials. In many other places, trees are cut for firewood, and plant stalks, estimated at $\mathbf{4 4 0}$ million tons annually, are burned rather than plowed under to maintain soil structure and fertility. This often results in reduced crop production and soil erosion. Northern grasslands have also been overgrazed by excessively large livestock populations.

The Chinese have made herculean efforts at afforestation and grass planting to stabilize slopes, beautify cities, provide windbreaks and hold back desert encroachment. Since 1982, about 200 million people have planted an average of five trees each year, mostly on National Afforestation Day. In the past, the focus of the campaign was on the northern half of the country, but concern about erosion has led to increasing concentration on the upper and middle reaches of the Yangzi River. The results have been quite impressive around the cities and villages of North China and along the highways that link them. They have been more problematic in remoter areas, especially on the hills of the south and along the fringes of the deserts in the north and west.

Figures vary on the extent of deserts in China; some say 13 percent of total land area, others, 33 percent. Similarly, reports on desert control range from glowing to gloomy. The optimists cite progress in afforestation, especially with the Great Green Wall, a long shelter belt covering millions of acres across the northeast, north, and northwest. They note other successes in planting grass and bushes to stabilize the edge of deserts and in establishing trees around villages, in fields, and along roads in desert areas.

Pessimists claim that desert areas have expanded by 29 percent, to 82 million acres, over the past 30 years. They cite short-sighted grazing and cultivation practices, overextensive irrigation that deprives noncrop vegetation of water, and long-term climatic change. Furthermore, even the Great Green Wall is in serious trouble. The central government, which had contributed less than one-fifth of the shelter belt's funds, has cut back on its support. The number of trees planted has fallen behind target for two years in a row, in part because the Ministry of Forestry cannot afford to buy seedlings. It is millions of dollars in arrears to seedling farmers for last year's stock. As elsewhere in China, maintenance of the Great Green Wall is underfunded, leaving it inadequately protected against insects and fire. The 13 provinces in the area do not appear to be willing or able to provide the necessary funds. Satellite imagery indicates that the shelter belt, like the Great Wall it was named after, is highly fragmented and has succumbed in many places to the ravages of nature and human neglect.

\section{Loss of Farmland}

It is not just in the uplands and along the dry desert fringes that China's traditional land use is threatened. There is as much concern over the loss of productive agricultural land in the lowlands where most people live.

China's land area is slightly larger than that of the United States. It produces roughly the same amount of grain from a comparable cropping area. (China compensates for its much lower cultivated area by extensive double- and triple-cropping.) Unlike the United States, however, it would be very difficult for China to expand its cultivated area beyond the present level. Most of China's land is too dry or too high for agriculture, and the lowlands that are most suited for crops are also prime land for industrial and residential development. Despite considerable efforts at land reclamation, the total amount of farmland has declined from over 270 million acres in the mid-1950s to about 237 million acres today. Concern over the use of prime farmland for other purposes has intensified in the mid-1980s, as cities and towns have expanded and farmers themselves have built homes on former cropland.

To some degree this is a normal feature of economic development. Where alternatives exist, land is usually much more valuable when devoted to industrial or residential purposes than when it is used for crop production. In addition, China's farm sector has continued to grow by producing higher yields per unit area and 
more valued products. Nonetheless, many of China's leaders are concerned that this growth is not sustainable in the long run and that agricultural land, once lost, can never be regained.

In the past, controls over transfers of land from one use to another were crude and haphazard. Since all land belonged to the state or the collective, little need was felt for policy instruments such as zoning or differential taxes to control land-use activities. The result was often poorly considered development of sites for industries, residences, and even graves.

In 1986, the government initiated a number of activities for land-use control. The Land Management Law provided for the first time for zoning and landuse registration, as well as penalties for land uses that cause ecological problems such as serious soil erosion. The State Land Control Bureau was established to supervise a land control administration extending all the way to the township level. The first national program for land development was worked out, and a survey was made of nonagricultural uses of land.

The reported annual loss of land to nonagricultural purposes declined from 2.5 million acres in 1985 to under 1.25 million acres in 1987, although the effect of the new measures on the decline is not certain. In 1988, further measures were proposed to stop encroachment on arable land, including land markets and taxes on nonagricultural land use. Central government officials have called on their local counterparts to give land management as much attention as they do family planning. If successful, a combination of zoning and land markets should lead to both greater economic efficiency and improved land management. However, it remains to be seen how well the new system will work where it counts, namely, at the local level.

\section{Soil Fertility and Urban Wastes}

Even where the soil stays put, the nutrient demands of increased agricultural yields have caused soil fertility to decline in many areas of China. As with deforestation and loss of farmland, recent problems in soil fertility reflect long-term trends. In accordance with Mencius' assessment over two thousand years ago that "they fertilize their fields but not enough," some Chinese leaders attribute the loss to a reduction in the use of organic manure, including night soil and green fertilizers such as alfalfa. Certainly, in some cases, farmers have cut back on fertilization, either because of unprofitable returns or perhaps due to a lack of willingness to make long-term improvements in land that they may not be able to keep, retain, or sell. More commonly, however, farmers have switched to chemical fertilizers. These may not provide the long-term benefits to the soil structure that organic fertilizers would, but they do provide many of the key nutrients such as nitrogen in a cleaner, more convenient way.

The more immediate effect of the switch to chemical fertilizers may not be on soil fertility but on the urban waste disposal problem. The productive farmlands around China's major cities were once nourished by urban night soil and other organic wastes. Farmers or their agents paid urban dwellers for their sewage. Those days are long past. It is said that today's farmers do not even bother to gather the animal droppings on the roads along their fields.

The problem is not due entirely to a shift in fertilizer use. From the farmers' standpoint, the coal ash and inorganic waste that comprise well over half of urban solid waste are themselves destructive to the soil-and the ash is not separated from other organic wastes. Furthermore, farmers are now more aware of the health hazards associated with using night soil.

The reluctance of farmers to use the waste, which has increased rapidly with rising urban living standards, has led to serious disposal problems. Beijing, which treats over 7,000 tons of solid wastes and more than 4,000 tons of sewage each day, is surrounded by nearly 5,000 small garbage dumps covering a total of over 1,500 acres. Tianjin has dumped over 10 million tons of industrial wastes on 1,075 acres since 1974. As nearby landfill sites are filled in, sanitary workers in some cities simply unload their burdens along highways or other public land. The Songhua River in northernmost Heilongjiang province has become clogged and befouled by garbage dumped on the ice surface during the long winter by Jiamusi City. The costs of treatment and disposal of urban wastes could eventually limit the growth of China's cities.

The need to act is urgent in some places, however. Many of the urban wastes of Shanghai and other areas around the Yangzi estuary are dumped not on land but in the rivers or nearby ocean. The health dangers were shown dramatically in the first three months of 1988 , when 290,000 residents of Shanghai contracted hepatitis A; forty-seven of them died. Students returning to Beijing from Shanghai were placed in quarantine for six weeks, and at least one government agency refused to meet with visitors from Shanghai. The panic diminished as the disease did not spread appreciably beyond those who had eaten raw hairy clams. The clams, it turns out, had acquired the virus from the polluted ocean waters off the Yangzi estuary.

\section{Air Quality}

The poor air quality of many of China's cities immediately strikes a visitor. China's reliance on coal for in- 
dustrial, commercial, and household energy seriously pollutes the atmosphere, inside as well as outside the home. The need for space heating highlights China's distinction as one of the few low-income countries with cold winters.

China, the world's leading coal-producing nation, annually burns about 900 million metric tons. Concentrations of sulfur and nitrogen oxides, carbon monoxide, and suspended particulates are all high in most of China's cities. The daily total suspended particulate (TSP) content in the air in almost 90 percent of Chinese cities exceeds the national minimum standard, which is the maximum level recommended by the World Health Organization.

The continuing ability of China's government to mobilize and concentrate resources, including its regulatory powers, can produce dramatic results at a specific site or in a well-defined task. For example, from 1980 to 1984 , the air over Shenyang, the largest industrial city in the northeast, had the highest measurements of TSP among China's major cities and one of the highest in the world. Subsequent cleanup efforts appear to have been fruitful because Shenyang was recently declared the region's first "smog-controlled area." However, programs that do not appear on the government's agenda cannot lay the same claim to its limited financial and political resources. As a result, successes tend to be localized and are sometimes not sustained. While Shenyang's air was apparently being cleared up, that of the nearby city of Benxi became so laden with particulates that satellite photographs in July 1988 could not penetrate it to show the city below.

This led Chen Yun, chairman of the Central Advisory Committee and the second most powerful elder statesman in China, to call for increased funding for pollution control beyond the current 0.6 percent of national income. Song Jian, director of the State Council's Environmental Protection Committee, urged enterprises to increase the share of technological innovation funds they spend on environmental protection from the current 2 percent to the 7 percent minimum mandated by law-an indictment of the level of enforcement of existing regulations.

China's decisionmakers are exploring and developing other energy sources, such as large dams on the main stems of the Yangzi and Yellow rivers, liquefied petroleum gas for home cooking in major cities, and nuclear power plants such as the controversial Daya Bay installations near Hong Kong. Most of these alternatives are costly, however, as is control equipment. As in the case of water and land, a bigger payoff may come from improvements in conservation, particularly by increasing the burn efficiency of coal. Some progress has been made in this area, but incentives to improve coal use are hampered by a low-price policy and inadequate incentives for state enterprises to economize.

\section{The Management Challenge}

Renewable resource management involves major tradeoffs between short-term exploitation and long-term sustainable development, or perhaps no development at all in cases such as wild rivers; between direct or indirect state regulation and free markets; and between local self-sufficiency and reliance on outside sources. Central to choosing from these, indeed a major social choice itself, is the establishment of an institutional framework and process for making these choices and enforcing the results.

The protection and improvement of China's water, land, and air have the support of senior government officials at the center, such as Deng Xiaoping and Chen Yun. The Chinese have a long way to go, however, before they can reach a true neo-Daoist accommodation with nature that provides for improvements in economic well-being while maintaining the quality of the environment. Economic growth itself tends to produce pollutants; budgets are tight; and environmentalists must operate through a government structure that, with few exceptions such as the population control policy, has not shown itself notably capable of mobilizing resources for the sustained, widespread development that it would take to deal with many of the country's environmental problems.

Environmentalism has stronger political support at the center than at the local level where most of the bills to ameliorate the problems have to be paid. Successes are many, but spotty and not always sustained. Still, China has made great strides in recognizing and analyzing its environmental problems and in setting up an administrative structure to deal with them. If the government can put greater financial resources into the effort, despite recurrent budget and inflationary crises, and establish an effective system combining administrative with market regulation, it may succeed in both stimulating the economy and leaving subsequent generations both a higher material standard of living and a natural environment worth living in. 


\section{CHAPTER NINE}

\section{Evolutionary Changes in \\ Chinese Culture}

oes China need a uniform set of values and cultural practices to remain unified as a nation and develop and prosper? If so, what combination of traditional Chinese customs and values, Marxist-Leninist (or Maoist) practices, and Western influences should be used to mold Chinese culture in the reform era? Is it even possible to forge a new cultural orthodoxy out of such disparate elements? Should any such cultural orthodoxy be allowed to emerge naturally out of the competition among different ideas and cultural systems, or should the central authorities strictly control what cultural elements are allowed and attempt to define and impose their vision of a cultural orthodoxy on the population? Many countries in Asia and elsewhere have grappled with the problem of how to combine native and foreign cultural elements into a cohesive whole. But in China during the reform both the fact that not two but three distinct cultural alternatives are under contention - traditional Chinese, Marxist-Leninist/socialist, and Western-and that there have been such erratic swings in governmental preference for and suppression of these alternatives in the past makes the problem of defining and developing a cultural orthodoxy particularly difficult.

Chapter nine was prepared by Martin Whyte, Director of the Center for Research on Social Organization and Professor of Sociology at the University of. Michigan.
This problem is hardly new. Throughout Chinese history, the issue of how to maintain cultural cohesion has engrossed rulers and thinkers alike, for "being Chinese" was defined more in cultural terms rather than by territory or citizenship. The challenges involved in confronting external influences such as Buddhism, Islam, and Christianity; occupying lands inhabited by nonChinese populations; and being ruled by non-Chinese (the Mongols in the 13th and 14th centuries and the Manchus from the 17th to the 20th centuries) continuously tested the cultural cohesion of China.

For the past two thousand years, most Chinese would have strongly affirmed that China did require an enforced cultural unity to survive. This judgment is based on a different set of assumptions than those that have influenced the West recently. In fact, within Western societies, the United States is perhaps the furthest from China.

\section{The Quest for Cultural Cohesion Prior to 1949}

During the last two thousand years, the dominant philosophy of China, which was influenced by Confucianism and its later variants and interpretations, conceived society ideally as a giant hierarchy of human relationships and interdependencies. Values were concerned primarily with how individuals should behave toward 
their parents, children, older and younger siblings, teachers, employers or employees, local officials, and all others with whom they interacted within this hierarchy. Only if each individual followed the proper conduct would there be social harmony, and if the entire population could be taught and made to obey the proper conduct, there would be societal unity, strength, and prosperity. In this utopian vision, all political leaders, including the emperor, were considered moral guardians and preachers rather than administrators. If political authorities did not maintain cultural uniformity by propounding orthodoxy and screening out alien values and practices, setting a positive moral example, teaching the proper conduct, and enforcing compliance by their subjects, then, it was thought, chaos would prevail.

This vision obviously did not accommodate autonomous subcultures, free competition between groups and ideas, individual privacy and freedom of conscience, and other ideas cherished in the modern West. The American assumption, nourished by a multiethnic heritage, that competition between groups, ideas, and values leads, almost like Adam Smith's invisible hand concept in economics, to national strength and eventually, perhaps, to some sort of naturally evolving cultural consensus is quite alien to most Chinese. Indeed, many Chinese wonder how it can be that American society has not yet been torn apart by its cultural diversity and freedom.

Throughout the imperial era most Chinese accepted on faith the idea that even though the specific content of Chinese culture and values might be modified and expanded over time, it was still necessary for the central authorities to define the orthodoxy of the day and forcibly impose it. But in the final years of imperial China, the quest for cultural cohesion was sorely tested by internal disintegration and by the growing impact on China of the Western powers. In the late 19th century, a struggle emerged between court conservatives and modernists, with the conservatives determined to defend traditional Chinese ways and resist Western influences. However, even the modernists did not propose accepting Western cultural assumptions. Rather, they argued that China faced yet another instance in which elements of a new, alien set of cultural influences had to be selectively accepted, while still maintaining strict official control over the process. For that purpose, they popularized the slogan, "Chinese learning as the foundation, Western learning for its practical applications (zhongxue wei ti, xixue wei yong)."

It can be debated whether various Western techniques of science, armament, medicine, and law really could have been extracted from their Western context and used in China without giving rise to conflicts with traditional Chinese culture and values, as this slogan implied, but the issue was never put to a true test. Instead, the weakness of the Qing state and the forceful imposition of Western influence by foreign traders, diplomats, missionaries, and others prevented the imperial authorities from maintaining the control over cultural life that they sought. The results only confirmed the beliefs of most Chinese that an imposed cultural orthodoxy is vital to national unity. Much of the century prior to 1949, particularly following the fall of the Qing dynasty in 1911, was characterized by cultural diversity and competition accompanied by disunity and social chaos.

Between 1911 and 1949, a variety of efforts were made to define a new cultural orthodoxy and to use this to restore national political unity. China's students and intellectuals, in particular, flirted with a wide variety of beliefs and philosophies, and in those years advocates of liberalism, pragmatism, socialism, Christianity, pacifism, sexual liberation, Esperanto, rural literacy campaigns, scientism, and general Westernization could be found. Indeed, almost any new faith or set of ideas found eager adherents in China. Figures like John Dewey, Bertrand Russell, and George Bernard Shaw visited China and met eager crowds of disciples.

In the years known as the May Fourth Period (following 1919), many searchers for a new faith mounted caustic attacks on traditional Chinese culture and values, which were described as the root causes of fatalism, conservatism, individual unhappiness, and the inability of China to resist her foreign tormentors. But in spite of the considerable cultural diversity and competition of those years, for most of those involved the issue was not a search for personal and group solace and fulfillment in the midst of chaos; it was instead a contest to determine what the content of a new and modern Chinese culture might be. The final goal was still to find the most appropriate set of ideas and values that could be used to unite the Chinese people and make the nation strong again.

When Chiang Kai-shek established shaky political unity after 1927, he and other leaders of his Nationalist regime attempted to define a new cultural orthodoxy that was an amalgam of Western and traditional Chinese ideas, excluding backward and superstitious elements. However, the Nationalist regime's efforts to formulate this new cultural orthodoxy, as in the New Life Movement in the mid-1930s, were extremely vague. In the end the Nanjing government never had sufficient power to effectively impose any set of values.

During the century prior to 1949 , Japan was forging an accommodation between traditional and Western cultural elements, so that each new foreign practice was not seen as a threat to fundamental Japanese ways. In China during the same period, the debate over how to accomplish this transition was never resolved. Indeed, it remains unresolved even today. 


\section{Mao's Revolution and Chinese Culture}

At first glance, it might appear that the victory of the Chinese Communist Party (CCP) in 1949 marked a fundamental victory of alien Western culture over traditional Chinese culture. After all, the CCP itself was a product of the May Fourth Period, when Mao Zedong and other founders of the CCP vigorously denounced the evils of traditional Confucian ways, eagerly read recently translated Marxist texts, and tried to follow events in the newly established Soviet Union. When the CCP came to power in 1949, Marxism-Leninism (or Marxism-Leninism-Mao Zedong Thought) was proclaimed the new orthodoxy, and Confucianism and a whole range of traditional customs and values were denounced and suppressed.

The hostility of the CCP toward traditional Chinese culture only reached its zenith during the last 10 years of Mao's life. During the early years of the Cultural Revolution (1966-69), Red Guards, inspired by Mao, ransacked private homes and vandalized temples and monuments in an effort to eliminate the "four olds"old ideas, culture, customs, and habits. Large quantities of old scrolls, porcelain, musical instruments, and other priceless objects were destroyed or confiscated by the Red Guards or in some cases were destroyed tearfully by their owners in the hope of warding off Red Guard wrath. Ancestral tablets and shrines were ransacked and destroyed, monasteries were closed, and monks and nuns were forced to devote themselves to "socially useful labor" in the fields, mines, and factories. Traditional opera performances were banned and were replaced by a limited number of new "revolutionary operas" developed under the personal supervision of Mao's wife, Jiang Qing. In 1973, a few years after the reigning in of the Red Guards, a campaign was launched against Confucianism in an effort to eliminate the lingering influence of the ideas of China's greatest philosopher.

\section{The Overlap Between Maoist Rule and Chinese Tradition}

It would be oversimplifying things to view the period of Mao's rule as an overall assault on traditional Chinese culture and the reform era as primarily a revival of this long-suppressed traditional culture. The reality is much more complex. Even though the CCP espoused a Western ideology, Marxism-Leninism, the establishment of the People's Republic in 1949 in no way constituted a victory for wholesale Westernization and a repudiation of traditional Chinese values. In certain very basic respects, Maoist rule emphasized fundamental Chinese traditions and defended these against rival Western ideas. It may not be too far-fetched to argue that Maoism in power represented a last effort, now abandoned (at least for the moment), to defend traditional Chinese culture against Western cultural influence.

To be sure, the CCP was not simply a traditional dynasty disguised in Marxist-Leninist slogans. A variety of far-reaching institutional changes were made in Chinese society; many traditional customs and cultural practices (such as arranged marriages, burials, spirit mediums, and kowtowing to elders) were discouraged or banned; and new ideas, concepts, and cultural forms were forcefully introduced, in some cases in the face of popular resistance or incomprehension. Spoken dramas with factory workers as heroes, an emphasis on struggle and social class unity rather than on harmony and kinship solidarity, suppression of mercantile instincts, pronouncements that man was descended from apes, encouragement to call nonkin "comrade" and one's spouse "beloved," and many other new things about CCP rule took many, if not most, Chinese a while to become accustomed to. As a result, China became a very different kind of social order. There really was a CCP-led revolution in China.

But in certain respects Maoist rule was not really so iconoclastic and, in fact, was deeply rooted in Chinese tradition. Ancient Chinese assumptions about social order were built upon and reinforced, even though they began to be interpreted in Marxist-Leninist, rather than in Confucian, terms. Society was conceived of as a vast bureaucratic hierarchy in which every individual was to have a place and be subordinated to the social group (now termed a collective) in which he or she was enmeshed. National unity was to be fostered by developing a coherent set of values (to which the specifically modern term ideology would apply) that would mandate how to behave, rather than by promulgating a national code of laws and administrative procedures. Primary duties of political leaders at every level, as in imperial China, were to maintain the coherence of the official ideology, to indoctrinate the population, and to enforce compliance. Any conception of autonomous subgroups, independent cultural innovation, or a freewheeling competition of ideas was directly contrary to the Maoist ethos, as it was to the traditional imperial doctrines.

So the content of the culture in Maoist China was in many ways new, but the idea that China required a uniform culture to survive as a nation and that the authorities should enforce an orthodoxy to maintain cultural, and thus political, cohesion was very old. Indeed, the vigor with which Mao and those around him imposed their new orthodoxy reflected the fact that their 
Marxist-Leninist convictions in this instance reinforced traditional Chinese assumptions. Socialism entails central planning and regulation not only of economic production but also of all social life, including culture and values. In contrast to traditional Chinese thought, the prevailing image of society in Marxism-Leninism is a society as a single, well-regulated factory, rather than as a hierarchical chain of human relationships, but the implications are much the same. There is one correct way for society to be organized, and cultural unity and officially imposed ideology play central roles in maintaining societal cohesion. Allowing alternative values and cultural practices would hinder the pursuit of socialism and communism and foster political disunity.

\section{Enforcing a New Cultural Orthodoxy}

In spite of the considerable overlap between traditional Chinese and Marxist-Leninist assumptions about cultural unity, there is also a basic difference in practice. The CCP, using modern technology, a huge central bureaucracy, and organizational practices learned from the Soviet Union, had the wherewithal to put these ideas into practice much more thoroughly than its imperial predecessors ever could have dreamed. The result was much tighter central control over schooling, the mass media, literature, the performing arts, social life, and even styles of dress and leisure activities. Even prior to the Cultural Revolution, the CCP had successfully used its increased powers to change traditional Chinese culture. From suppressing secret societies to campaigning against mah-jongg, from reforming Chinese opera plots to purging and standardizing school textbooksall facets of Chinese cultural life witnessed the activist efforts of China's communist revolutionaries. Still, the goal was to forge a Chinese society united around a common set of values and ideas-a very traditional goal.

The Maoists used the power of the state vigorously to exclude Western cultural influences and, after 1960, even Soviet influence. More was involved than simply expelling foreigners in the 1950s and taking over the factories, schools, churches, hospitals, newspapers, and other property they had owned or controlled. Efforts were also made to restrict and control cultural influences from foreign movies and magazines and foreign travelers. In addition, there were campaigns against Western ideas and values that had gained a foothold in China in the previous century, such as enthusiasm for the rule of law, an autonomous press, and competing political parties, in an effort to stop the process referred to as "creeping Westernization."

The CCP did not exclude all foreign influences entirely (although during the Cultural Revolution it nearly did). Foreign influences penetrated China only in a manner that the government chose and on the government's terms. Western orchestras on tour and Western exchange students were allowed, whereas listening to foreign radio broadcasts and independent travel abroad were not. Special hotels, stores, and travel arrangements were developed in the 1950s under the pretext of shielding foreign visitors from the hardships of Chinese life, but their more basic purpose was to protect most of Chinese society from possible "contamination" by foreign guests. The desire of China's 19th century modernizing elite to carefully screen foreign influences and selectively admit only those elements deemed practical had eluded them but came much closer to being realized by their post-1949 successors.

Mao used the power of the state in an effort to forge a new cultural orthodoxy that would eliminate large parts of both the traditional inheritance and Western culture. The CCP had a greater ability to impose this new orthodoxy throughout China than any of its imperial predecessors. Yet, for all of the vigor with which this effort was pursued, it is now clear that it was only partially successful. Many values and practices that were attacked in Maoist China were only driven underground and did not disappear. And after Mao's death, as controls were being relaxed, both traditional and Western heterodox (in the Maoist view) influences began to resurface.

\section{The Reforms and Chinese Culture}

The death of Mao Zedong in 1976 and the implementation of the reform program by his successors have produced a rethinking of all aspects of the Maoist social order. This, in turn, has resulted in a reaction against the rigid and impoverished cultural straitjacket that characterized China during Mao's last decade in power. In most respects, the reformers have allowed and encouraged a very broad cultural liberalization.

Writers have been permitted to explore the dark side of society and to depict themes, such as romantic love and distaste for politiçs, that Mao's partisans had tried to ban during the Cultural Revolution. Artists have been allowed to revive traditional styles and to experiment with a variety of Western forms, including abstract and surrealistic art. Freedom of religious belief and practice has been reinstated, and Buddhist temples, Islamic mosques, and Christian churches have been revived and refurbished with official approval and are to be staffed by both rehabilitated religious leaders and new graduates of reopened monasteries and seminaries. School curricula have been revamped with a renewed emphasis on pure academics and the establishment of 
formerly proscribed or neglected fields, such as law, sociology, political science, and business management.

The mass media have witnessed an explosion; a few tightly controlled and highly politicized publications have been replaced by a bewildering variety of new, specialized journals, catering to those interested in calligraphy, classical Western music, the martial arts, weightlifting, and other decidedly nonpolitical realms. The effort to impose a uniform "proletarian drab" style of dress has been repudiated, and a variety of clothing styles are now available, ranging from traditional Chinese slit-sided dresses to miniskirts and from "Mao jackets" to Western suits and ties. Formerly suppressed or discouraged hobbies and leisure pursuits ranging from tropical fish raising to stamp collecting and playing mah-jongg have been allowed to revive, and specialized markets in birds, fish, spirit incense, funeral supplies, and other products are now widely visible.
Official tolerance of differing ideological ideas has also increased. Ideas that would have been risky to express a few years ago, such as having officials be bound by laws, recognizing and allowing interest groups to compete in the political arena, or making divorce easier, can now be expressed. Controls over the communications technologies that facilitate the transmission of ideas and cultural products independently of the state have been relaxed. Computers and printers, cassette recorders, mimeograph machines, photocopying machines, and videotape recorders are not found everywhere, but an increasing number of them are in the hands of private individuals and local organizations who use them in a variety of ways, not all of which please the authorities.

Of course, there are clear limits to the reform-era liberalization. Perhaps most important, the ideas and cultural products of the late Mao era are for the most

\section{Box 9.1 The Fifth Generation Chinese Filmmakers}

The liberalization of cultural life in post-reform China has encouraged the budding of an authentically Chinese cultural renaissance less encumbered by the past requirement of an explicit revolutionary message. The emergence of a new, distinctive generation of younger Chinese filmmakers is one sign of this innovation. These filmmakers, usually called the "fifth generation"' in reference to their place in the succession of Chinese filmmakers and to their relative coherence as a group, are exploring fresh themes and techniques as they seek to create indigenous forms of expression in what many Asians still regard as an imported art.

Most of them are members of the first post-Cultural Revolution degree class (1978-82) at the Beijing Film Academy, China's only film school. Because they were exiled to work in rural communes or state farms during the Cultural Revolution and often made their way back to Beijing through army service or urban factory jobs, they probably have had more exposure to the totality of Chinese life than their predecessors in the Chinese film industry.

The fifth generation first came to international attention in 1985 with the film Yellow Earth, directed by Chen Kaige. Widely acclaimed as the best Chinese-produced film since 1949, it presents a metaphor of China's "opening up" in the 1980s. Ideas injected from outside a largely closed community cause initial turmoil, but seem to offer hope. The usual unambigous happy ending of more orthodox films is missing. Whereas earlier Chinese films relied on dialogue and narrative to convey the story, Chen innovatively uses stunning landscape images.

The film is set in a poor village not far from Yan'an, the Communist Party's wartime headquarters. A Red Army man is visiting to collect folk songs to adapt for use in party propaganda. His talk of the improved lives of women in Yan'an makes a deep impression on Cuiqiao, a young peasant girl who is soon forced to marry a much older villager. Cuiqiao eventually sets out for Yan'an but apparently drowns. In the final sequence of the film, the men of the village are praying for rain. Cuiqiao's young brother imagines that the Red Army man has returned, but the film ends before he and the audience can be sure of this.

Another fifth generation filmmaker, Tian Zhuangzhuang, set two of his films in minority regions of China that are unfamiliar to most Chinese. In The Horse Thief, Norbu, a Tibetan, is expelled from his clan and wanders through the wild natural beauty of his homeland, flinging himself into any and all religious rites to expiate his sins. Tian does not attempt to explain these ceremonies. He leaves it to the audience to ponder the questions raised regarding man's relations with nature, religion, and society. Like Chen's Yellow Earth, Tian's films go beyond the narrow focus on revolution and class oppression characteristic of most post-1949 films.

The future of artistic innovation by China's young filmmakers is in doubt for several practical reasons. Continuing bureaucratic interference is one problem. Moreover, with increased government reluctance to sustain earlier levels of subsidies, filmmakers must give increased attention to box office receipts. Chinese audiences have not flocked to see these difficult films, the Chinese equivalents of arthouse movies. Chinese filmmakers are competing with television and a wider range of leisure activities as well as popular foreign action films. In mid-1988 studios began to seek production funds from outside investors, a move that is likely to make box office receipts an increasingly important consideration. 
part now proscribed, and there is political risk in advocating them. One does not see people quoting Mao's sayings from their "little red books," performing Jiang Qing's model revolutionary operas, or publicly advocating mounting new class struggle campaigns. Periodically the authorities do fulminate against "harmful" cultural influences that have arisen in the reform era and purge writers, arrest alleged disseminators of pornography, and publish new regulations against unauthorized publications. Still, the growing diversity and liveliness of cultural life in the post-Mao era is indisputable.

\section{Impact on Chinese Traditional Practices}

The traditional cultural legacy has been a major beneficiary of the post-Mao liberalization. There are signs everywhere in China today of a revival of a variety of traditional Chinese practices. A vast amount of new research and publishing on ancient and imperial China is under way. The past no longer has to be portrayed as a simple conflict between heroic but oppressed peasants and evil and cruel landowners and officials. Traditional operas, music and dance, and performance troupes and associations dedicated to the preservation of these arts, have been revived. Traditional-style painting, calligraphy, and other fine arts have enjoyed a renaissance as well, and there is a new pride emerging in China's artistic heritage. Many tombs, monuments, and temples have been renovated and reopened, and they are less likely now to be accompanied by signs describing the exploitation and misery the common people suffered during their construction.

Confucius has also been "rehabilitated." His ancestral temple and adjacent facilities have been refurbished, new journals and associations devoted to the study of his writings have been established, and international symposia have been convened on the lessons of Confucian ideas for the modern world. An underlying theme in this "neo-neo-Confucianism" is that the great philosopher's values must have played a role in explaining the economic successes of the other East Asian Confucian societies (Japan, Taiwan, South Korea, Hong Kong, and Singapore); therefore, the People's Republic could benefit as well from renewed respect for his legacy. In addition to the possible material benefits, it is argued that greater stress on Confucian values like moderation, benevolence, harmony, and filial piety will help to overcome the social conflicts and frayed nerves that are legacies of the Mao era.

Of course, the authorities do not look positively upon all the traditional Chinese practices that are reviving, such as lavish weddings and funerals, siting graves in arable fields, investment by peasants in constructing new ancestral lineage halls instead of schools; secret socie- ties and Daoist sects; fortune tellers, spirit mediums, and traffickers in women; and female infanticide. Some forms of corruption that appear to be widespread in the reform era, involving demands for bribes and manipulation of personal connections, are also perceived as reflecting harmful traditional "feudalist" influences.

\section{Western Cultural Influences}

The relaxation of official controls and the open-door policy have fostered a major new infusion of Western cultural influences. The reform policies have increased the number of diplomats, foreign businessmen, teachers, and tourists in China and have resulted in tens of thousands of Chinese traveling to the West, either on short business trips or for extended periods of study. Contacts have intensified with Chinese living abroad who have already made their accommodations with Western cultural practices, and particularly with Chinese from Hong Kong and Macao and those visiting from Taiwan. The number of Taiwanese returning to visit has been increasing since 1987 . In some parts of China, and particularly in the coastal areas of Guangdong and Fujian provinces, the primary bearers of Western cultural influence are these overseas Chinese, rather than non-Chinese foreigners.

Most foreign broadcasts are no longer banned or jammed, and in fact listening to them is an approved way to help develop valuable foreign language skills. Foreign movies and television series are now regularly shown in China, although the selection criteria are obscure. Movies range from The Sound of Music to Convoy, a violent film about American truckers; television shows range from "Little House on the Prairie" to "The Man from Atlantis," a series canceled long ago in the United States. American football's Super Bowl and baseball's World Series now appear on Chinese television, to the evident puzzlement of many Chinese viewers. Japanese, European, Latin American, and recently even Soviet films and television shows are now shown in China as well. Stories about movie and music stars from the West, Hong Kong, and Taiwan now compete for space in popular magazines with stories about China's own rising celebrities.

Almost 40 years after the CCP railed against the seditious poison spread by Hollywood movies, their return to China has an impact in some surprising places. Recent visitors to Lhasa, the capital of Tibet (Xizang), have been startled to see at the foot of the Potala Palace (the former home of the exiled Dalai Lama) an establishment known as the Rambo Bar. Customers are enticed in by a mural on the front wall of Sylvester Stallone in character, wrapped in bandoleers and presumably destroying communist (but non-Chinese) enemies. 
Numerous other signs of foreign cultural influence are everywhere in China's cities, and occasionally even in the rural backwaters. A very partial listing includes video parlors, pool halls, amusement parks (complete with bumper cars and corkscrew roller coasters), disco and ballroom dancing, jazz, Pepsi and Coke, cosmetic surgery, Kentucky Fried Chicken, white wedding gowns, bodybuilding and beauty contests, commercial advertising, rock bands, tennis, golf, windsurfing, and motocross racing. And an increasing variety of translated foreign literature is also available to Chinese readers, ranging from classic works available earlier but suppressed during the Cultural Revolution, such as those by Shakespeare, Dickens, and Victor Hugo, to currently popular fiction, James Bond stories, and nonfiction by writers such as Lee Iacocca, Dale Carnegie, Freud, Malinowski, Gorbachev, and various Western popular writers on business management and futurology.

Along with these forms of Western cultural influence, there are also officially sanctioned efforts to gain a new appreciation for Western institutions and values. Simplistic analyses of the America run by Wall Street conspirators have given way to efforts to understand how the American electoral system works, how Congress does its business, the role of think tanks and foundations, the influence of religious organizations, and other long-neglected topics. American Studies has been booming in Chinese academe, and the study of other foreign countries has also enjoyed a renaissance. Of particular interest are Western ideas about business management. Chinese study economics and business abroad, and Westerners come to China to teach Keynesian economics, cost accounting, public relations, and other capitalist methodologies. With this increased learning from the West have come efforts by some to promote the acceptance of alternative ideas and values such as the pursuit of individual happiness, the independence of young people from their elders, risk-taking and competition, and the advantages of private enterprise and market-based distribution of goods and services.

However, not all of the Western influences in China today have new and external sources. In the reform era, those Chinese who were trained in the West or who were influenced by Western culture and ideas prior to 1949 have resurfaced, just as have champions of China's traditional culture. Surprisingly, these people not only show little sign of having been affected by decades of "thought reform" but also, in some cases, enthusiastically take up where they were so rudely interrupted by the revolution. Proposals and manifestos drafted 40 or more years ago are dusted off and aired for public discussion, friendship contacts overseas are reestablished, and writings disowned in the Mao era as tainted by bourgeois values are prepared hastily for republication. Similarly, communities that appeared earlier to have renounced their Christian faith have now resumed a vibrant level of religious activity, with few apparent losses of membership despite the long years of official persecution. And musicians trained in Western classical styles before 1949 have hurried to relearn their discarded repertoires and display their fondness for Mozart, Beethoven, and Bach once again. Thus the reform era has revealed that an important domestic constituency for Western culture survived the Mao era and is eager to lend its support to the new openness toward Western influence.

As with the revival of traditional Chinese culture, the authorities are by no means pleased with all of the new forms of Western cultural influence. Considerable debate has surrounded the appearance in China of such things as bodybuilding and beauty contests. Critics cite a long list of harmful influences that have erupted in China at least partly as a result of the open-door policy. Foreign influences are blamed, for instance, for increases in premarital sex, divorce, venereal disease, prostitution, pornography, drug addiction, and even for general increases in crime and juvenile delinquency rates. Of equal or even greater official concern is the alleged foreign effect on popular values, particularly among the young. The open door, it is argued by critics, has fostered doubt about the virtues of socialism, China's institutions, and the leadership of the CCP, and may be creating perceptions that the institutions and values of foreign societies are superior. The same theme was sounded in the early 1950 - - Chinese must be dissuaded from the notion that "the American moon shines brighter than the Chinese moon."

Even though there have been persistent efforts to monitor and control foreign contacts and to prevent harmful ideas and practices from entering, the increase in foreign influence has been so rapid, and its forms so massive and diverse, that it has proved impossible for the authorities to effectively monitor and control everything. To some extent this inability is inherent in the reform process itself, for the granting of local autonomy that is vital to the economic reforms inevitably leads to activities and influences that are outside of the range of central controls.

\section{Cultural Dilemmas}

Given the increased cultural liveliness and diversity in recent years, the question persists as to how much the basic rules of the system have changed. Does the increased "blooming and contending," involving traditional Chinese and Western alongside socialist cultural practices and symbols, indicate that the authorities' efforts to impose cultural uniformity have ceased? This is far from being the case, although the issue could be debated. There are, to be sure, some intellectuals and 
some reformers who come close to adopting a Western "marketplace of ideas" argument-that the open door and other current policies are good because they introduce many new ideas and cultural practices, that the competition among ideas and practices will be a healthy way to weed out bad or outmoded elements, and that as a result a modified and stronger, more dynamic Chinese culture will emerge.

Two points should be noted about this sort of argument. First, it seems to represent the view of a minority, with most participants in the cultural debate being uncomfortable with the sort of unbridled cultural competition being advocated. Second, even in this minority view, competition and variety in the cultural realm are perceived as necessary but temporary. The necessity arises from China's need to recover from the isolation and cultural impoverishment that Mao led the nation into in his final years. Once the elements of a modified and revitalized Chinese culture have been identified, the competition would be curtailed, with a new and improved cultural orthodoxy dominant. In other words, even in this minority and apparently protoWestern view, permanent cultural competition of the sort that appears to reign in the West is rejected as too chaotic for China.

Many if not most participants in the debate on the future of Chinese culture are not even willing to go as far as this minority position. Even the temporary, free competition of ideas and values is seen as threatening to the social order. To those who hold this view, Chinese culture needs to be modified and changed, but this should be done in a careful and controlled manner. Individuals, groups, organizations, and localities should not have too much autonomy to experiment with new ideas and practices. Rather, the authorities should identify those new elements that are suitable to modern life under Chinese conditions and foster experimentation and innovation in those areas; other elements that are not deemed so suitable should continue to be proscribed. This is a familiar formula. It is very much a continuation of the "Chinese learning as the foundation, Western learning for its practical applications" notion advocated by China's 19th century modernizing elite.

Critics of recent cultural trends differ on whether the resurgence of traditional practices or the influx of Western influences is more problematic and potentially harmful. Some argue that China's most serious problems arose from the way centralized state socialism reinforced the worst, feudal tendencies of the traditional legacy, producing "little emperors" ruling over factories, offices, and schools throughout China. For such critics the revival of traditional cultural forms and the new respect given to Confucian ideas is particularly worrisome, since these can only make the effort to eliminate the "feudal remnants" from contemporary China more difficult.

Others argue, however, that Western influences pose more of a threat than the revived traditional practices. In addition to the greater familiarity of the traditional heritage, there is also the comfortable (but probably mistaken) view that harmful traditional practices are the products of backwardness and ignorance; therefore, with time, modernization, and rising educational levels, these will gradually disappear. No such assumption can be made about foreign influences. In addition to their being more alien to begin with, they are found in societies that are more modern and well educated than China. The dilemma for the screeners of such foreign influences, then, is how to identify which elements of Western culture are required by any modern society and thus have to be allowed to develop in China and which elements are unnecessary for China's modernization effort. Where do neckties, rock music, premarital sex, or for that matter electoral democracy and competitive individualism fit?

As the central authorities have struggled with these problems, they have been unable to come to a consensus. Clearly, the more radical among the reformers feel that China benefits from most of the new Western cultural infusions and that the resulting changes in Chinese practices to date have been too slow. In other words, the new influences have still only had a partial and superficial effect, mostly among the young and urban intellectuals, but have not yet had much impact on the deep recesses of Chinese organizations, families, and individual psyches. More conservative leaders perceive the infusions of Western influence to date as excessive and undesirable. They see the open door causing both a rising tide of social problems and a loss of national pride and faith in the system. These conservatives argue that the loss of centralized control over cultural innovation and transmission is even more dangerous than the specific kinds of harmful phenomena fostered, for it spells the doom of any serious attempt to forge cultural orthodoxy and will thus lead to political fragmentation and social chaos.

Twice in the 1980s these conservatives have managed to launch campaigns designed to gain greater control over Chinese cultural life and punish those involved in spreading "unhealthy" Western influences-in the Anti-Spiritual Pollution campaign of 1983-84 and the Anti-Bourgeois Liberalization campaign of 1987. That each of these conservative initiatives faltered after a few months, after claiming a few prominent victims and intimidating many others, does not mean the debate is now over. It merely indicates that for the moment the conservatives have not managed to gain sufficient support within the elite for a more thorough cultural crackdown. 
Meanwhile, the ordinary population is confused and uncertain. The Chinese man and woman on the street (and rural lane), while generally appreciative of improved consumption standards and less oppressive political controls, often find the lack of clear consensus on values and cultural forms unsettling. For people who have grown up in a highly didactic and moralistic society, being faced with options and with no clear standards for selection is unfamiliar. Should they cultivate an interest in Western classical music, rock, traditional operas, Chinese folk tunes, or perhaps favorite martial tunes from the socialist tradition (or all of the above)? Should they wear the latest Western fashions or retain the proletarian drab of the Mao era? Should they push their children down the "white road" toward academic learning and expertise, the "yellow road" toward business success and financial wealth, or the "red road" toward political activism and party membership? How should they celebrate a family wedding or a funeral? How would they react if a son came home and announced he wanted to leave a state job to go into private business, live together with his girlfriend without benefit of marriage, or go into training to become a Buddhist monk?

This uneasiness of the general population has several sources. It is not simply that people are unfamiliar with being faced by such choices. Nor is it solely a matter of being nervous in the face of the uncharacteristic restraint of the CCP and worried that in the future, if this restraint is abandoned and cultural uniformity is again forcefully imposed, they may be criticized for having made the wrong choices. As much as anything else, this popular uneasiness can be attributed to the fact that both in imperial times and in the Maoist era, Chinese were accustomed to living in a society in which habits and cultural forms were infused with political and moral meanings that flowed from the cultural orthodoxy - a trait still very much alive. Even though China is an avowedly atheistic state, in a certain sense, until the reform era, China was a minimally secularized society. The sort of secularized, pragmatic societies in which Westerners have grown up, in which most spheres of daily life and culture are seen as detached from higher moral battles, has never been part of the Chinese experience. For this reason many Chinese have the gnawing feeling that they are sailing into uncharted seas without a clear moral rudder. Today's situation may then be interpreted not so much in terms of new freedoms and choices, but as a moral vacuum in which, for example, individuals are encouraged to get rich without experiencing the restraints of socialist, traditional Confucian, or Western moral values.
The efforts of the reformers to alleviate these concerns by formulating a revised ideological and moral framework to guide China in the new era have so far not been very convincing or satisfying to the population. The Chinese people are told that various ideas and practices are good or bad, but they are not given a clear set of principles to live by that would allow them to tell the difference. The concept of China being in the "primary stage of socialism," popularized by the reformers in 1987, does not seem to provide the needed moral guidance. This concept mainly justifies allowing traditional Chinese and Western capitalist, as well as socialist, practices to coexist for some time to come, as long as they contribute to modernization.

Many Chinese are skeptical of the idea that their society can be guided by a moral framework that simply says that whatever works economically is good and whatever does not is bad. Some Chinese thinkers are attempting to fill the moral void by adapting portions of Confucianism, the writings of the early Marx, and Western doctrines of individual rights and dignity to form a new amalgam they call Chinese humanism. However, these efforts are still at an early stage, and what guidance these new humanist ideas might provide for meeting a variety of problems in life is still not very clear. So, as yet, no coherent set of moral standards has emerged to replace those discredited by the excesses of the Cultural Revolution. The reformers worry that their conservative opponents may be able to play on public unease about the moral vacuum and cultural confusion to engineer a return to a more closed-door society with an imposed and anti-Western cultural orthodoxy.

China has struggled for more than a century to cope with the problems involved in adapting Chinese culture to the modern world. Because the Chinese define "being Chinese" in cultural terms and both the elite and the masses believe that forging a unifying cultural orthodoxy is vital, cultural debates have constantly spilled over into the political realm. Similarly, political leaders in imperial, Republican, Maoist, and reformera China have all had devising and implementing the proper cultural policy high on their political agenda. But in spite of this century of efforts, the debate, particularly in terms of how Chinese culture will accommodate Western influence, is still unresolved, and arguments in this realm remain volatile. It is still very unclear whether a well-defined cultural orthodoxy will emerge from the new round of debates on these issues in Deng Xiaoping's China and what form that orthodoxy might take. 


\section{CHAPTER TEN}

\section{China's Role in the Asia-Pacific Region}

hina holds a central place in the Asia-Pacific region. It is East and Southeast Asia's largest country in terms of population, land, and natural resources. It occupies a geographically pivotal position; China's land and sea claims give it boundaries with every country in East and Southeast Asia except Cambodia and Thailand and with most South Asian countries. Chinese culture has had a strong impact on Japan, the Korean peninsula, and Vietnam, and the outward migration of its people has resulted in substantial Chinese minorities in most of Southeast Asia. Therefore, even at times of weak Chinese governments, China was an important part of the Asia-Pacific region. However, during much of the 1950s and 1960s, China's closed economy and revolutionary foreign policy influenced its principal regional role; it defended adjacent friendly socialist governments and threatened nonsocialist ones. In the late 1980s, China has changed, broadened, and deepened its Asia-Pacific role as a result of its growing economy, large trade volume, and effective diplomacy. It is now a significant part of the region's economic life and plays a political role in a wide variety of important regional issues. As China's economic and military strength grows, it is also being increasingly regarded as a global power.

Chapter ten was prepared by Allen S. Whiting, Professor of Political Science and Director of the East Asian Institute, University of Arizona, and Charles E. Morrison, Coordinator of the International Relations Program, East-West Center.
China's role is still being defined. What China regards as its rightful position in the region and what its neighbors accept as a legitimate Chinese role can and sometimes do clash. China's ultimate role will be defined by the Chinese and other Asia-Pacific peoples through a give-and-take process of regional relations in the context of larger global developments.

\section{Change in Chinese Foreign Policy}

China's foreign policy has changed significantly in several ways since Mao Zedong's death in 1976 and the subsequent ascendancy of the reformists headed by Deng Xiaoping since late 1978 . The revolutionary rhetoric and support for insurgency movements in Southeast Asia that characterized China's regional involvement during the Maoist era has been transformed into a more stable and pragmatic foreign policy rationally linked with security and economic interests.

The decision-making process in Chinese foreign policy has become less personalized and idiosyncratic. In his day, Mao dominated the process and defined China's international role, while Zhou Enlai acted as principal advisor and implemented foreign policy. In contrast, Deng Xiaoping has tended to rely on a more collegial style, although he remains the guiding strategist on major policy questions. This change has been partially institutionalized in state and party foreign policy decision-making groups, directed by Premier Li Peng and Vice Premier Wu Xueqian. 
The policy directions established by Deng also differ from those set by Mao in substance and their longerterm implications. The Maoist policy of economic selfreliance and isolationism was discredited and overturned. The open-door policies of the reformers have resulted in a growing network of vested interests in trade, technology, and capital relations with the outside world. As China's economy has become increasingly integrated with the world economy, the policies that have facilitated this cannot be reversed without serious economic hardship and political cost.

These changes have brought China into the international community as a nation-state acting among nation-states, pursuing goals and choosing means common to most states. There are, however, at least two ways in which China's foreign policy remains qualitatively different from those of most other Asia-Pacific countries. First, Chinese leaders believe that China, by virtue of its history, size, population, and economic potential, is or should be a global power. Although Chinese foreign policy is no longer couched in terms of revolutionary rhetoric, it is often cast in terms of global principles, issues, and objectives. China's smaller neighbors also have difficulty in perceiving China as just another nation-state. Second, China is a divided nation, and the reunification of Taiwan with the mainland continues to be a programmatic goal that affects foreign policy. Although reunification remains a high priority goal, it has receded as a point of friction in China's foreign policies with other countries, especially the United States.

\section{China's Relations with the Large Powers}

Since the founding of the People's Republic of China in 1949, its leaders have often been preoccupied with external security threats, thought to come principally from the superpowers. When Chinese leaders felt threatened, they sought protection through a close relationship with one or the other of the superpowers. In the 1950s, China's relationship with the Soviet Union laid the foundation for the new China to survive and grow. An estimated 10,000 Chinese studied in the Soviet Union; and the modernization of military weapons, the beginning of China's nuclear capabilities, and the early transformation of the Chinese economy all took place with Soviet assistance.

China's relationship with the United States played a similar role in the 1970s. After the 1969 border clashes with the Soviet Union, China wished to limit one source of threat and began probing the U.S. willingness to reduce confrontation. Since U.S. power in the region seemed to be waning during the 1970s following the defeat of the U.S. effort in Vietnam and since the Soviets had completed a large military buildup, China identified Soviet hegemony as its principal security threat. By the time that Sino-American relations were fully normalized in early 1979, Beijing's relationship with Washington was so close that it amounted to an informal anti-Soviet alliance.

In the 1980s, with the reassertion of American military power, China has been less concerned about an imbalance in Soviet-American strength. It has also been carrying out its own military modernization effort as part of the Four Modernizations program and seems to have increased self-confidence in the deterrent capabilities of its own forces. This has created an environment favorable to a more even-handed position between the two superpowers, and China has improved its relations with the Soviet Union while maintaining a close relationship with the United States. This foreign policy accords with the preference for avoiding dependence on any single foreign power and also allows Beijing, to a certain extent, to bargain between competing states. Moreover, by reducing the costs of a confrontational foreign policy and permitting constructive economic relations with both superpowers, it conforms with the needs of the economic reform program.

\section{Sino-American Relations}

The United States is the largest source of foreign investment for the Chinese and China's second largest market. The continuation of good political and economic relations with the United States is not only important in its own right but also a key to China's relations with American allies, such as Japan. The United States and China both seem to have achieved a deeper understanding of the value of their relations in the 1980s. The normalization of diplomatic relations with Beijing and the abrogation of the U.S. security treaty with Taiwan in early 1979 was controversial within the United States, and the Republican candidate in the 1980 presidential election, Ronald Reagan, promised to upgrade relations with Taiwan. After he took office, the United States also proposed to sell advanced fighter FX aircraft to Taiwan despite Beijing's protests. Other difficult issues in Sino-American relations in the early 1980 s included restrictions on sales of high technology items to China and trade restrictions, especially on textiles.

These disagreements were largely resolved during the first half of the 1980s, the most important breakthrough being a 1982 agreement limiting U.S. weapons sales to Taiwan to prenormalization levels and gradually reducing them. President Reagan visited Beijing and Shang- 
hai in 1984, and high-level exchanges of foreign policy, commercial, and defense officials have occurred regularly. Although Taiwan has been removed as an active irritant in Sino-American relations because of the 1982 agreement and Beijing's own efforts to woo Taipei, there are continuing problem areas, such as congressional criticism of China's family planning programs and human rights policies in Tibet. However, the Sino-American relationship remains a central pillar of Deng's foreign policy and is likely to continue to overshadow Sino-Soviet cooperation.

\section{Sino-Soviet Relations}

The gradual improvement in Sino-Soviet relations began after Soviet leader Leonid Brezhnev's 1982 speeches in which he called for normalization. In July 1985 , the two countries signed a five-year trade agreement, and in February 1987, border negotiations were resumed after a nine-year hiatus. Although the initiative and enthusiasm for detente has continued to come primarily from the Soviet Union, China's economic reform program gives it an incentive to reduce the costs of the confrontation with the Soviet Union. Detente may transform the long land border from a volatile flash point of deliberate and accidental clashes into an avenue for interaction between locally complementary economies, as had traditionally benefited Xinjiang in the west and northeast China. Moreover, because both countries are socialist states, detente with the Soviet Union may face fewer ideological and domestic political problems than the earlier detente with the United States. It can also draw on the legacy of the cooperative Sino-Soviet relationship of the 1950s. Some of the first concrete steps involved visits by Soviets previously involved in Chinese aid projects.

China approached detente with a considerable degree of caution. Deng outlined three obstacles to full normalization of Sino-Soviet relations: Soviet troops along the northern border, the Soviet invasion of Afghanistan, and Soviet support for Vietnam's intervention in Cambodia. These obstacles were not intended to be an insurmountable barrier to normalization. The process of detente continued even at times of little apparent progress in removing the obstacles, but they allowed China to set the pace of rapprochement and reassured both China's domestic public and its external partners, especially the United States and Japan, that no precipitous changes of foreign policy would take place.

The obstacles also appear to have given China bargaining leverage. By the end of 1988, China could claim significant progress in removing the obstacles, although it is debatable how much this progress should be attributed to Chinese policies as opposed to other pressures on the Soviet Union. A Soviet division of ap- proximately 12,000 troops has been withdrawn from Mongolia, and most Soviet divisions along the border have moved back and are under strength, a tribute to the relaxation of border tensions. Soviet troops were being withdrawn from Afghanistan, and the Soviet Union has put pressure on Vietnam to announce its own withdrawal program from Cambodia.

Despite the rapid pace of the normalization process, which will culminate in a Sino-Soviet summit conference when Mikhail Gorbachev visits Beijing in May 1989, the Chinese have made it clear that there will be no restoration of the Sino-Soviet alliance of the 1950s. From the Chinese perspective, the relationship should be one between equal states, both pursuing economic reform goals and engaging in mutually beneficial relations that contribute to the modernization process. Moreover, as China's regional and international roles expand, there is likely to be a continuing degree of SinoSoviet rivalry in areas of interest common to both countries, including the Korean peninsula, Southeast Asia, and the South Asian subcontinent.

\section{China's Asia-Pacific Relations}

Three major factors influence China's relations with its neighbors: fear of China's strength, suspicion of the Chinese overseas community, and competition for economic resources.

First, despite the repeated statements of Chinese leaders that China has no intention of becoming a superpower or playing a hegemonic role, the country's sheer size and the demonstrated energy of its people cause some in neighboring countries to fear that if the modernization program is successful, China cannot help but dominate the region.

Smaller country security fears of a neighboring large power are natural, no matter how benign that larger power might appear. However, in China's case, the revolutionary regional diplomacy of the past and continuing party-to-party relations with illegal communist parties in Southeast Asia have fed these fears. So has Southeast Asian awareness of China's military modernization. From a Southeast and South Asian perspective, China has not been shy to use its military power - to enforce its territorial claims against India in 1962, to punish Vietnam for its military intervention in Cambodia in 1979, and to assert its claims to islands in the South China Sea in 1974 and again in 1988.

Second, the overseas Chinese community complicates China's relations with many of its Southeast Asian neighbors. This community, which is economically advantaged, is resented in some of these countries and is suspected of being a potential fifth column, reinforc- 
ing Southeast Asian fears about China's ability to dominate the region using both external and internal pressures. On the other hand, overseas Chinese can also provide positive cultural or economic linkages with the countries in which they reside. For example, partChinese President Corazon Aquino of the Philippines visited her ancestral village while on a trip to China. As government-to-government relations have improved between China and noncommunist Southeast Asian countries, the overseas Chinese have stimulated trade and capital ties, contributing to China's economic development and Asia-Pacific economic role.

Third, there is fear in Asian developing countries of China as an economic competitor. China is widely viewed as a country of talented and hard-working people whose economic potential has been held back by socialist economic policies. Once China modified these policies by embarking on its open-door policy of seeking trade, technology, and capital, concern was expressed that Chinese competition for these resources would mean less for everyone else. The ASEAN countries, for example, put considerable effort into securing a commitment from Japan that its foreign aid to China would not be at the expense of the foreign assistance being given to ASEAN. These fears have been considerably reduced, as China has integrated into the world economy without significant disruption, but they remain in the background.

\section{Japan}

China's key Asian relationship is with Japan. Japan is China's largest foreign trading partner (excluding Hong Kong) and supplier of foreign assistance. Japan's foreign investment in China, about $\$ 2$ billion in 1987, is exceeded only by that of the United States and Hong Kong. Economic cooperation with Japan has thus been almost indispensable to the success of China's economic reform and open-door policies. This Japanese role in economic modernization overrides all other considerations in Sino-Japanese relations.

The difficulties in Sino-Japanese relations stem from bitter Chinese memories of the former enemy's brutal treatment of China, fears of rising Japanese nationalism, and suspicions about Japan's general role in the Asia-Pacific region and its aspirations regarding Taiwan. China protested in 1982 and 1986 against the wording of textbooks relating to Japanese prewar and wartime activities in China and in 1985 objected to the Japanese prime minister having attended ceremonies at the Yasukuni Shrine honoring Japanese war dead. The Chinese also expressed concern about growing Japanese militarism when in 1987 it was announced that Japan's defense expenditures would likely exceed the 12 -year-old ceiling of 1 percent of the gross national product (GNP). China also protested a Japanese court decision upholding Taiwan's legal status as owner of

\section{Box 10.1 China's Growing Maritime Power}

One of the four modernization efforts being pursued by China is the modernization of its defense forces, including the development of an ocean-going navy.

For years the Chinese fleet has been distinguished by its very large numbers of very small ships, reflecting the priority given to coastal defense. These small ships include coastal patrol craft, coastal mine sweepers, and patrol submarines that are designed to attack enemy surface vessels approaching the Chinese coast. In recent years, however, the People's Liberation Army Navy (the navy continues to be technically under the control of the army) has made substantial investments to augment its fleet. It now has 11 submarines with greater range and offensive capabilities and 18 missile destroyers. Its 34 frigates can protect China's increased overseas shipping, and its 9 large tankers give it a refueling capability that allows operations far from Chinese coastal bases.

In addition to ship acquisitions, there is other evidence of naval modernization. For example, in the 1980s the Chinese navy began to acquire experience in long-distance voyages. Naval groups have visited the North and South Pacific, Antarctica, and the Indian Ocean. Base facilities have also been upgraded, and in 1988, China's largest naval base near Qingdao in Shandong province became fully operational.

The strengthening of China's maritime power suggests an augmented set of naval missions. Aside from their traditional interest in the East Asian deployments of the two superpowers, the Chinese have expressed concern about growing Japanese naval capabilities. The naval modernization may partly be an effort to match Japanese strength.

Moreover, with the world's eighth largest merchant marine (by tonnage) and growing foreign trade, China, like other trading countries, is concerned about the security of its trade routes. Chinese leaders have also expressed their belief that new technologies will increase the military and economic value of the sea and its resources. They are determined to protect China's maritime resource claims, including China's claim to the Spratly (Nansha) archipelago.

Other countries with claims in the Spratly group include Indonesia, Malaysia, the Philippines, and Vietnam. So far, Chinese naval forces have been involved in clashes only with Vietnam, but other southeast Asian countries can be expected to be concerned about China's growing naval power and apparent willingness to use that power on behalf of its interests. 
a student dormitory in Japan. This caused Deng Xiaoping to warn publicly of possible attempts by "a foreign power" to take over Taiwan.

As the perception grows of an erosion of U.S. influence in Asia, the Chinese are thus clearly concerned that Japan, encouraged by the Americans, might supplant the United States, the dominant force in the region. At current exchange rates, Japan's military expenditures are the world's third largest, and Japan has purchased a technologically sophisticated military force, including growing naval capabilities. China has looked askance at the U.S. role in urging the development of these forces, as demonstrated in its criticism of Washington's pressure on Tokyo to assume air and sea surveillance responsibilities of sea lines of communication 1,000 miles south of Tokyo and Osaka.

Despite such concerns, both the Chinese and Japanese governments have attempted to contain bilateral political and economic irritants and suppress overt disputes, such as their overlapping claims to the Senkaku Islands north of Taiwan and the areas of the continental shelf under the East China Sea. In the longterm future, however, there is a danger that the two will increasingly regard each other as rivals for a leading Asia-Pacific role.

\section{The Korean Peninsula}

China has an acknowledged role as a major actor on issues relating to the Korean peninsula. The survival of the North Korean regime in the 1950-53 war resulted exclusively from Chinese intervention. North Korea is almost entirely bounded on the north by China, and across this border flow weapons, oil, and energy provided by the dams along the Yalu River. The relationship between the two countries has been ritualistically described as that between "lips and teeth."

Nevertheless, contemporary Sino-North Korean relations fall far short of those implied by this rhetoric or the security treaty they signed in 1961. Ironically the treaty itself raises a problem for Beijing insofar as Pyongyang's behavior may threaten instability on the peninsula, pulling China into unwanted conflict. During the past twenty years, North Korea has shot down an American reconnaissance plane, seized an American intelligence collection ship, sent a terrorist team to Seoul to attempt to storm the residence and working quarters of the South Korean president, built tunnels under the demilitarized zone (DMZ), killed a number of South Korean cabinet members and other officials accompanying the South Korean president on a visit to Burma, and, according to the confession of a North Korean agent, destroyed a South Korean commercial airplane on a flight from the Middle East to Bangkok. China has also been troubled by a warming of Soviet-
North Korean relations during the 1980s, which included two visits by North Korean leader Kim Il Sung to Moscow, sales of advanced Soviet aircraft to North Korea, and North Korean permission for Soviet military forces to visit North Korean ports and use airspace.

Chinese unhappiness with North Korea and the foreign economic policies associated with the reform program set the context for growing, but still unofficial, interaction between China and South Korea. The rising cost of Japanese products has added to the Chinese incentive to import cheaper manufactured goods from South Korea and from Taiwan. Indirect trade with South Korea, mostly through Hong Kong and Japan, was thought to exceed $\$ 1.1$ billion in 1987, more than double China's trade with North Korea. South Korean steel and automobile manufacturers are among the many businesses setting up joint ventures in China. Trade offices are planned between South Korea and the Chinese province of Shandong, across the Yellow Sea. The Soviet Union's own economic opening to South Korea following the 1988 Summer Olympics, which both Chinese and Soviet teams attended despite North Korean calls for a boycott, has probably given China more latitude with respect to informal relations with the South.

Even as informal relations with South Korea have grown, Chinese leaders reaffirm China's diplomatic support for North Korea. China has said it will not recognize South Korea, and it routinely praises North Korean proposals on reunification and the withdrawal of American troops from South Korea. Although China is playing a new role as an economic partner with both Koreas and probably tries to discourage aggressive North Korean behavior, it is uncertain that China can or is willing to attempt a diplomatic role as a mediator in the long inter-Korean rivalry.

\section{Southeast Asia}

It is with Southeast Asia that China's regional role appears to have changed the most between the Maoist and reformist periods. During the Maoist period, China backed the Hanoi regime in its war against the French and later against the South Vietnamese and Americans. China also supported, rhetorically more than financially and materially, communist insurgencies in Burma, Malaysia, and Thailand. The Chinese Communist Party had close fraternal relations with the Indonesian Communist Party and was believed by the Indonesian military to have been behind the Indonesian Communist Party's 1965 coup attempt.

This policy shifted in the early 1970s when China established diplomatic relations with Malaysia, the Philippines, and Thailand. On the other hand, Sino- 
Vietnamese relations deteriorated as China linked itself with the Khmer Rouge government of Cambodia. In mid-1978, thousands of Chinese fled Vietnam, and in November 1978, Vietnam entered into a defense agreement with the Soviet Union in anticipation of its invasion of Cambodia. Although this did not prompt a direct Soviet response when China invaded Vietnam in February 1979 to "teach a lesson" to the Vietnamese for their invasion of Cambodia, it made the possibility of direct conflict real. Even more important to the Chinese from a security perspective, subsequent Soviet access to major air and naval facilities at Da Nang and Cam Ranh Bay in Vietnam permitted Moscow to extend its military power and surveillance capabilities far beyond the limits previously posed by its dependence on its base at Vladivostok.

These factors combine with subjective ones to color Chinese perceptions and policies toward Vietnam. The Chinese traditionally have taken a patronizing approach toward their southern neighbors. The close historical relationship between the Chinese and Vietnamese Communist parties during Vietnam's struggle for independence and reunification obscured but did not replace the historical legacy of difficult relations between the two countries. Vietnam was a Chinese province for a thousand years before the 10th century, and there were subsequent Chinese invasions or other forms of interference. For China, Vietnam's alignment with the Soviet Union showed betrayal, ingratitude for all the assistance China had previously given the Vietnamese, and a lack of deference.

China is actively involved in Indochina by supplying arms to the Khmer Rouge resistance in collaboration with the Thai military. Other Chinese military pressures on Vietnam have included minor border incidents, although no second "lesson" was administered, and some naval actions to assert China's claims over the Spratly Islands in the South China Sea, a group over which Vietnam, Indonesia, Malaysia, and the Philippines also have partial claims.

The betterment of Sino-Soviet relations, including Soviet willingness to engage in direct discussions on Cambodia with China, has improved the prospects for a settlement in Cambodia and an easing of bilateral Sino-Vietnamese tensions. After years of a rigid Chinese position in support of the Khmer Rouge, however, it was unclear how flexible China would become. In 1988, with Indonesia seeking to arrange talks between the Cambodian parties and between the Indochinese and ASEAN states, China did not want to appear to be an obstacle to the peace process. At the same time, China initially resisted a rewording of the resolution on Cambodia proposed by the ASEAN countries at the 1988 UN General Assembly session that condemned the past policies of the Khmer Rouge.
China's position on Cambodia is evolving in a manner that will provide more flexibility for the negotiators. During a November 1988 visit to Thailand, Premier Li Peng stated that China would support a freeze on military forces and their later dissolution or reduction to 10,000 troops for each faction. China is also supporting an international peacekeeping force. In January 1989 direct Sino-Vietnamese negotiations on Cambodia began.

In the economic sphere, China has become a significant economic partner of most of the ASEAN countries, aided by business connections through the overseas Chinese community. Singaporeans, for example, have been active as foreign investors and economic advisors in China. In the mid-1980s, as the ASEAN countries were seeking to expand and diversify their exports in the wake of the fall of commodity prices and increased protectionist sentiments in developed countries, they sought to expand economic relations with China. Indonesia, for example, which had frozen diplomatic relations with China in 1967, in 1985 allowed its businessmen to deal directly with China again, resulting in a significant expansion of trade.

Indonesia remains the ASEAN country with the deepest suspicions of China, stemming from the bitter coup experience as well as conflicting regional aspirations. The Indonesian defense minister, Benny Murdani, continues to describe China as Indonesia's foremost long-term security threat and argues that Chinese (and Soviet) economic reform programs are aimed at eventual international domination. Before normalizing diplomatic relations with China, Indonesian officials want assurances that China will not interfere in Indonesian internal affairs and an admission of complicity and an apology for the Chinese role in the 1965 coup attempt.

\section{South Asia}

China has played a significant role in the international politics of South Asia since the early 1960s when its relations with India deteriorated, culminating in the 1962 border war, and China's relations with India's rival, Pakistan, were elevated into a near alliance. Two factors were significant in the deterioration of SinoIndian relations: conflicting claims over large but sparcely populated mountainous territories and suspicions of Indian meddling in Tibet.

Border differences between India and China were basically settled in the 1962 border war with a Chinese victory. Despite the border talks that began in 1981, no formal settlement has ever been reached because of India's unwillingness to consider a territorial settlement on the basis of the line of actual control. In May 1987, there was a sudden escalation of tension when Beijing 
accused India of encroaching on Chinese-held territory and conducting military exercises in the border region, but the tensions were defused by new border discussions.

Improving relations in late 1987 and 1988 were facilitated by India's decision not to try to exploit internal tensions in Tibet. India is the place of exile for Tibet's most prominent leader, the Dalai Lama, and tens of thousands of Tibetan refugees who continue to agitate for Tibet's independence. However, when tensions openly erupted in Tibet in 1987, India adopted a strict noninterventionist policy, seeking to cool the activities of the refugee community in India. Sensing the change in Indian support, the Dalai Lama in 1988 offered to talk directly with the Chinese, giving up his previous demands for an independent Tibet. Moreover, in the context of improved Sino-Soviet relations, the Soviet-Indian relationship looks less threatening to China.

An important sign of improved Sino-Indian ties was Indian Prime Minister Rajiv Gandhi's 19-23 December 1988 visit to Beijing for the first summit meeting of the two countries' leaders in 28 years. It was agreed to form a joint working group to resolve border issues through consultation. The external environment, particularly improved Sino-Soviet relations, has also been favorable to reduced Sino-Indian tensions.

\section{Objectives and Roles}

It is commonly assumed that an agenda of foreign policy objectives frames decision making. The Chinese propensity to make statements of principles appears to justify such an approach, but the operational importance of principles in determining actual policies should not be exaggerated. Even during most of the Maoist era when the Chinese made choices about whether to deal with existing governments or with insurgents, flexibility was evident in its foreign policy. This flexibility has been much more manifest since Mao's death. Contemporary Chinese foreign policy appears to operate without a clear timetable or fixed modus operandi for deriving foreign policy from statements of national principles or objectives. Yet, the above discussion suggests that the existence of a set of objectives and sense of roles helped frame the reformist agenda.

\section{Taiwan}

Certainly, national unification remains an important objective. Following the agreements with Britain and Portugal to return Hong Kong and Macao to Chinese administration by the end of the century, Taiwan remains Beijing's last major territorial objective for na- tional reunification. In recent years, Beijing has pursued a policy of attraction, promising the Kuomintang leaders that if they would recognize Chinese sovereignty, they could maintain their own economic, political and judicial system, and even their own military. Beijing has reacted positively to the Kuomintang's policy changes allowing limited unofficial contacts between Taiwan and the mainland, but political developments on the island have raised concerns in Beijing about the future prospects for reunification. As the younger generation of native Taiwanese gradually replaces the older mainland Chinese Kuomintang leaders, Beijing fears that the commitment to "one China" may erode. Moreover, the more open political environment in Taiwan has given rise to an opposition party that includes advocates of self-determination or independence.

Beijing's threat to use force instead of its preferred means of negotiating unification has been explicitly linked to Taiwanese independence. Yet how and when this threat might be evoked remains uncertain. Deng set a precedent for flexibility when he adjusted his initial list of goals for the 1980s by extending the goal of unification to the 1990s. Blaming Washington or Tokyo for failure provides a scapegoat and allows other priorities to justify passivity or postponements. Implementing the threat to use force poses problems of potential failure as well as a sharp international reaction especially from those countries-the United States and Japan-on which Beijing relies most for succeeding in its economic modernization goals.

\section{Security and Status}

A central foreign policy objective of China, as for all governments, is to contain threats to its security. China's alliance with the Soviet Union between 1950 and 1960 , its participation in the Korean War, its nuclear weapons program, and its entente with the United States in the late 1970s and early 1980s helped counter perceived security threats. Beyond direct security concerns, however, China has sought to achieve proper acknowledgment of its regional and international status. Its efforts to balance its relationship with the two superpowers and to strengthen its ability to defend itself rather than relying on an alignment with a larger power appear to stem in part from this goal. China's behavior with respect to the Korean peninsula, Indochina, and India also seems not only to protect China's security interests but also to legitimize a major political role in regions around its periphery. Similarly, China's expressed concerns about Japan's growing military and political role in the region appear to reflect not just direct security concerns, but the fear that Japan will come to occupy a dominant place in the region at the expense of China's status and role. 
As part of its efforts to assert its regional and international status, China has increased its participation in international and regional institutions. It has joined the International Monetary Fund and the World Bank and is in the process of joining the General Agreement on Tariffs and Trade (GATT). Regionally, China has become a member of the Asian Development Bank and established a national committee to participate in the nongovernmental, but regionally symbolic, Pacific Economic Cooperation Conferences (PECC). China's greater international participation serves both economic and politico-diplomatic goals.

\section{Economic Development}

With the reformist economic agenda, a high foreign policy priority has been to serve China's modernization objectives. Under Deng's leadership, China has actively sought trade, technology, loans, and direct investment from abroad. The establishment of cordial relations with the major nonsocialist economies and China's participation in international financial institutions have proved successful from this perspective. Although the amount of direct foreign investment has been far less than the Chinese had anticipated and has been concentrated in a few sectors, overall, China's open-door policy has been successful. A country that 20 years ago had no foreign investment, no overseas loans, and one of the lowest ratios of foreign trade relative to the size of its economy, China now attracts a considerable amount of both concessional and nonconcessional capital and has been the developing world's largest trading nation.

China's changed development strategy and foreign economic policy, and its growth record in the past decade have, in general, made a strong contribution to the stability and growth of the region's economy. In contrast to the fears of China as an economic competitor, which dominated perceptions of China's role at the beginning of the modernization program, Asia-Pacific countries in general have found that they have successfully adjusted to China's integration into the regional economic system without serious negative repercussions to them. Since China has a strong rate of internal growth, it has been one of the dynamos of economic growth in the region over the past 10 years.

\section{The Challenge Ahead}

As China's modernization program continues, many unanswered questions remain in the minds of leaders throughout the Asia-Pacific region and the world about China's ultimate international role. China's record during the reformist era has been to join and support existing international institutional arrangements. Nevertheless, it would be difficult to describe China as a satisfied status quo power. China must still find a regional role that other countries will find acceptable and support, and this may require a considerable period of struggle, adjustment, and tension. Moreover, in advancing their own self-interests, the Chinese will increasingly have to consider the sensitivities and interests of other countries in areas beyond the Asia-Pacific region. For example, Chinese weapons sales in the Middle East became a matter of international concern during the latter stages of the Iran-Iraq War and caused the United States, in particular, to seek Chinese restraint. China was a country that traditionally saw itself at the center and as the head of a hierarchically organized world system. In the modern era, learning to live in a multipolar system as a large power among legally equal nations remains an important challenge ahead. 


\section{Appendix Tables}


Table 1 Population Indicators

\begin{tabular}{|c|c|c|c|c|c|c|c|c|c|}
\hline \multirow[b]{2}{*}{ Subregion/country } & \multicolumn{3}{|c|}{ Population (millions) } & \multicolumn{3}{|c|}{ Population growth rate } & \multicolumn{3}{|c|}{ Urban population $(\%)$} \\
\hline & 1960 & 1985 & $2010^{\mathrm{a}}$ & $1960-1965$ & $1985-1990^{a}$ & $2010-2015^{a}$ & 1960 & 1985 & $2010^{a}$ \\
\hline \multicolumn{10}{|l|}{ East and Southeast Asia } \\
\hline Brunei & 0.1 & 0.2 & $0.3^{\mathrm{h}}$ & na & 2.7 & na & na & 59.4 & па \\
\hline Burma & 21.8 & 39.5 & 66.5 & 2.3 & 2.4 & 1.6 & 19.3 & 30.0 & 48.8 \\
\hline Cambodia & 5.4 & 7.4 & 10.8 & 2.4 & 2.5 & 1.1 & 10.3 & 15.6 & 31.0 \\
\hline China: Mainland & 656.7 & $1,044.1$ & $1,362.3^{n}$ & $1.8^{n}$ & $1.0^{\mathrm{n}}$ & $0.5^{n}$ & $16.8^{n}$ & $21.0^{\mathrm{n}}$ & $33.6^{n}$ \\
\hline Taiwan & 10.6 & 19.1 & na & $3.3^{\mathrm{C}}$ & $1.9^{\mathrm{c}}$ & na & $11.0^{f}$ & $15.0^{\mathrm{g}}$ & na \\
\hline Hong Kong & 3.0 & 5.6 & 7.4 & 3.6 & 1.8 & 0.5 & 89.1 & 90.8 & 93.8 \\
\hline Indonesia & 96.7 & 165.5 & 229.0 & 2.1 & 1.6 & 0.9 & 14.6 & 25.3 & 44.5 \\
\hline Korea, North & 10.5 & 20.1 & 31.7 & 2.8 & 2.2 & 1.3 & 40.2 & 63.8 & 77.2 \\
\hline Korea, South & 25.0 & 40.9 & 53.5 & 2.6 & 1.4 & 0.6 & 27.7 & 65.3 & 84.3 \\
\hline Laos & 2.3 & 4.4 & 7.5 & 2.4 & 2.4 & 1.6 & 7.9 & 15.9 & 32.6 \\
\hline Malaysia & 8.2 & 15.5 & 23.5 & 3.0 & 2.2 & 1.1 & 25.2 & 31.5 & 49.5 \\
\hline Philippines & 27.9 & 54.7 & 86.6 & 3.0 & 2.3 & 1.3 & 30.3 & 39.6 & 56.4 \\
\hline Singapore & 1.6 & 2.6 & 3.1 & 2.8 & 1.2 & 0.3 & 77.6 & 74.2 & 81.9 \\
\hline Thailand & 27.0 & 51.6 & 75.6 & 3.0 & 1.7 & 1.0 & 12.5 & 15.6 & 30.4 \\
\hline Vietnam & 33.9 . & 59.5 & 90.0 & 2.2 & 1.9 & 1.2 & 14.7 & 20.3 & 34.8 \\
\hline \multicolumn{10}{|l|}{ South Asia } \\
\hline Bangladesh & 51.6 & 101.1 & 177.0 & 2.5 & 2.6 & 1.6 & 5.1 & 11.9 & 24.6 \\
\hline Bhutan & 0.9 & 1.4 & 2.2 & 1.8 & 2.0 & 1.4 & 2.5 & 4.5 & 11.4 \\
\hline India & 431.5 & 761.2 & $1,065.2$ & 2.5 & 1.8 & 0.9 & 18.0 & 25.5 & 41.9 \\
\hline Nepal & 9.4 & 16.5 & 27.6 & 1.9 & 2.3 & 1.5 & 3.1 & 5.8 & 14.1 \\
\hline Pakistan & 50.0 & 101.7 & 173.0 & 2.7 & 2.2 & 1.6 & 22.1 & 29.8 & 45.4 \\
\hline Sri Lanka & 9.9 & 16.4 & 23.3 & 2.4 & 1.8 & 0.9 & 17.9 & 21.1 & 30.7 \\
\hline \multicolumn{10}{|l|}{ Pacific islands } \\
\hline Fiji & 0.4 & 0.7 & 0.9 & 3.3 & 1.5 & 0.5 & 29.7 & 41.2 & 58.0 \\
\hline Kiribati & 0.05 & $0.06^{\mathrm{d}}$ & na & na & $1.5^{\mathrm{i}}$ & na & $29.7^{f, b}$ & $36.0^{\mathrm{g}}$ & na \\
\hline Papua New Guinea & 2.1 & 3.7 & 6.4 & 2.2 & 2.6 & 1.8 & 2.7 & 14.3 & 26.7 \\
\hline Solomon Islands & 0.13 & $0.25^{\mathrm{d}}$ & na & na & $3.5^{\mathrm{j}}$ & na & $9.3^{f}$ & $23.2^{\mathrm{g}}$ & na \\
\hline Tonga & 0.06 & $0.10^{\mathrm{d}}$ & na & na & $2.0^{\mathrm{k}}$ & na & $20.0^{f}$ & $26.0^{\mathrm{g}}$ & na \\
\hline Vanualu & 0.06 & $0.13^{\mathrm{d}}$ & na & na & $3.0^{1}$ & na & $16.2^{f}$ & $19.2^{8}$ & na \\
\hline Western Samoa & 0.11 & $0.16^{\mathrm{d}}$ & na & na & $0.8^{\mathrm{m}}$ & na & $20.3^{\mathrm{f}}$ & $23.6^{8}$ & na \\
\hline \multicolumn{10}{|c|}{ Pacific basin industrial market economies } \\
\hline Australia & 10.3 & 15.7 & 20.6 & 2.0 & 1.2 & 0.9 & 80.6 & 86.8 & 90.8 \\
\hline Canada & 17.9 & 25.6 & 31.5 & 1.8 & 1.1 & 0.6 & 68.9 & 75.0 & 81.5 \\
\hline Japan & 98.9 & 120.0 & 130.0 & 1.0 & 0.4 & -0.1 & 62.5 & 76.5 & 82.3 \\
\hline New Zealand & 2.4 & 3.3 & 3.9 & 2.0 & 0.8 & 0.5 & 76.0 & 83.7 & 88.0 \\
\hline United States & 180.7 & 237.7 & 286.7 & 1.5 & 0.8 & 0.6 & 70.0 & 74.2 & 81.5 \\
\hline
\end{tabular}

na $=$ not available.

Notes:
a. Based on United Nations
e. 1976-1980.
j. $1970-1976$.
medium variant projections.
f. 1970 .
k. 1976-1981.
b. Including Tuvalu.
g. 1980 .
c. $1958-1966$.
h. Year 2000.
l. 1967-1979.
d. 1983.
i. 1973-1978.
m. 1971-1976.
n. Includes Taiwan.

Sources: United Nations, World Population Prospects: Estimotes and Projections as Assessed in 1982, New York, 1985. Data for Taiwan, Kiribati, Solomon Islands, Tonga, Vanuatu, and Western Samoa from Asian Development Bank, Key Indicators of Developing Member Countries of ADB, Manila, 1984, and from United Nations, Demographic Yearbook, various issues, New York. Data for Brunei from Far Eastern Economic Review Asia 1984 Yearbook, Hong Kong, 1984; and United Nations, Demographic Yearbook 1983, New York, 1985. 
APPENDIX TABLES

Table 2 Aging and Health Indicators

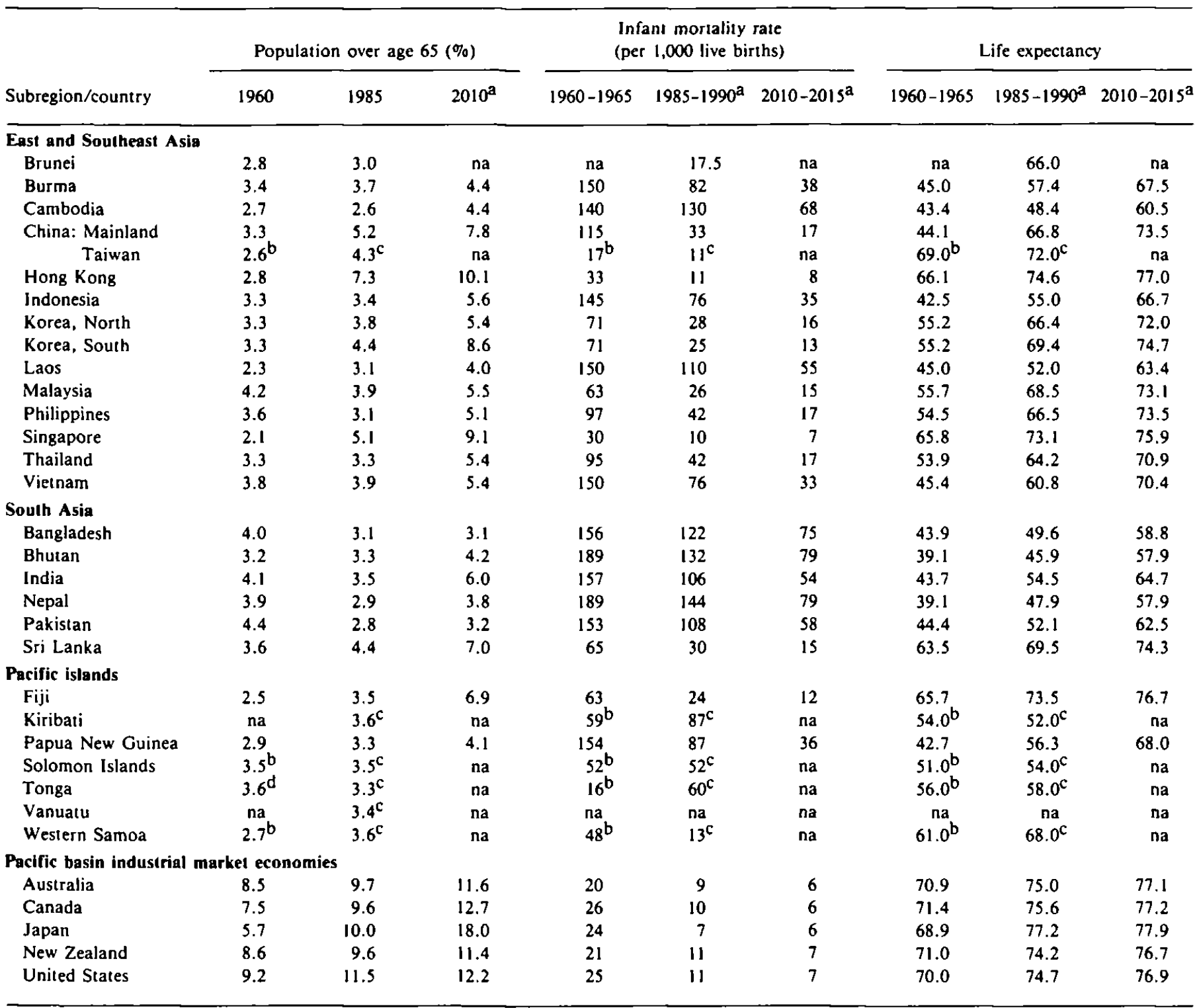

na $=$ not available.

Notes:

a. Based on United Nations medium variant projections.

b. 1970 .

c. 1980 .

d. 1956 .

Sources: United Nations, World Population Prospects: Estimates and Projections as Assessed in 1982, New York, 1985. Data for Taiwan, Kiribati, Solomon Islands, Tonga, Vanuatu, and Western Samoa from Asian Development Bank, Key Indicators of Developing Member Countries of ADB, Manila, 1984, and from United Nations, Demographic Yearbook, various issues, New York. Data for Brunei from Far Eastern Economic Review Asia 1984 Yearbook, Hong Kong, 1984; and United Nations, Demographic Yearbook various issues, New York. 
Table 3 Average Annual Real Growth Rates and Nominal Levels of GDP and Per Capita GDP

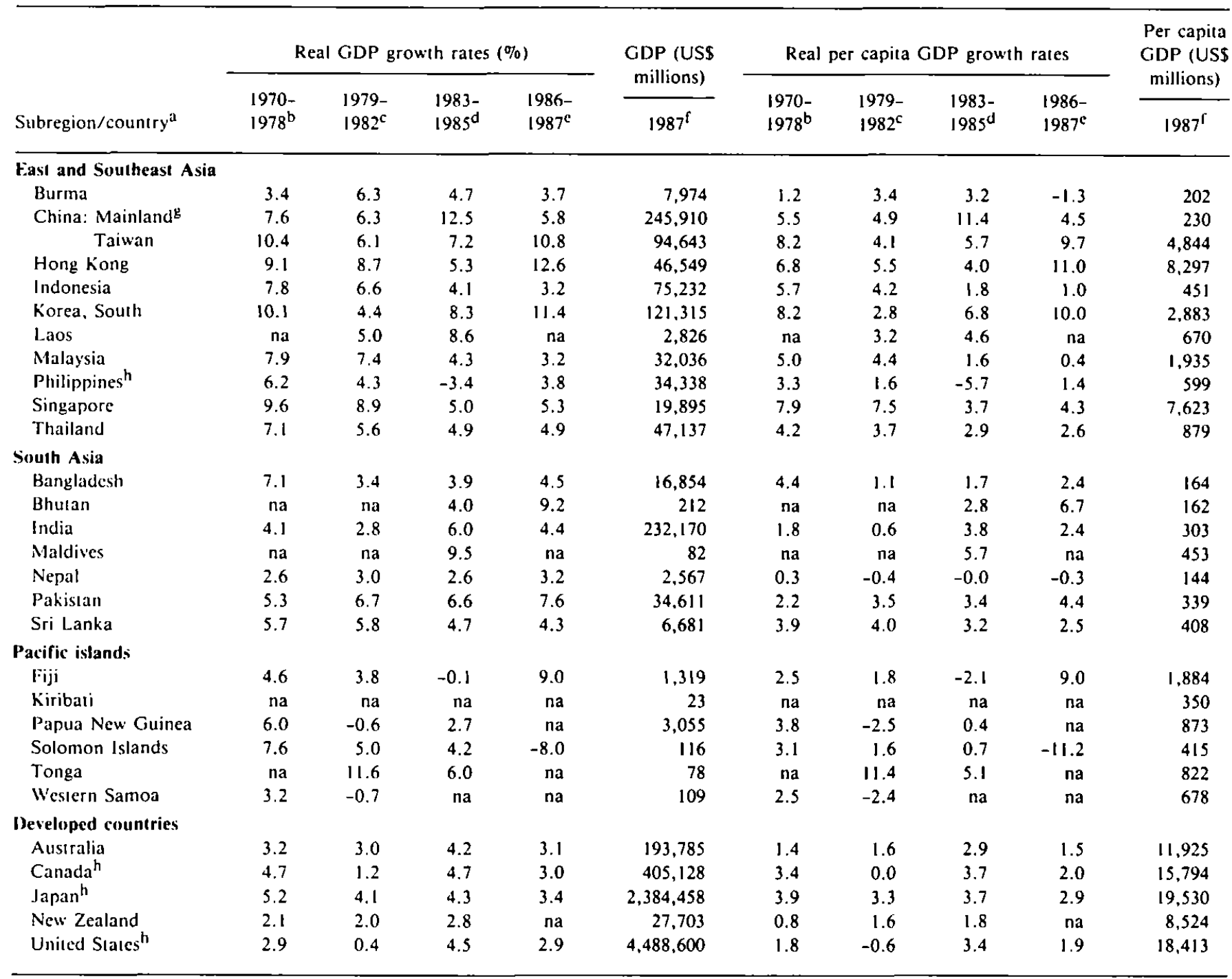

$\mathrm{na}=$ not available.

Noles:

a. Data not available for Brunei, Cambodia, North Korea, Mongolia, Vietnam, Cook Islands, New Caledonia, and Vanuatu.

b. 1971-1978 for Malaysia; 1973-1978 for Solomon Islands; 1974-1978 for Bangladesh, Pakistan, and China.

c. 1980-1982 for Laos.

d. 1983 for Tonga.

c. 1986 for Burma, Indonesia, Bhutan, India, Sri Lanka, Fiji, Canada, Solomon Islands, and Laos.

f. 1983 for Tonga: 1985 for Maldives; and 1986 for Burma, Indonesia, Laos, Bhutan, India, Fiji, Solomon Islands, Western Samoa, and New Zealand.

g. Grow'th of real national income and real national income per capita. Nominal values for 1987 refer to net material product.

h. GNP.

Sources: Asian Development Bank, Key Indicators of Developing Member Countries of ADB, Vol. XV (April 1984); XVI (April 1985); XVII (July 1986): XIX (July 1988). Hong Kong, Census and Statislics Deparıment, Estimates of Gross Domestic Product 1966-1983. Hong Kong, Census and Statistics Department, Hong Kong Monthly Digest of Statistics. August 1986 and August 1988. International Monetary Fund, International Financial Statistics, 1979. 1986, and 1988 yearbooks. Republic of China, Central Bank of China, Financial Statistics: Taiwan District, Republic of China, various monthly issues. Republic of China, Council for Economic Planning and Development, Taiwan Statistical Data Book, 1988. 
Table 4 Average Annual Inflation Rates (growth rates of GDP deflators in percent)

\begin{tabular}{|c|c|c|c|}
\hline Subregion/area ${ }^{a}$ & $1970-1978^{b}$ & $1979-1982$ & $1983-1987^{\mathrm{C}}$ \\
\hline \multicolumn{4}{|l|}{ Fisit and Southeast Asia } \\
\hline Burma & 10.1 & 3.7 & 1.2 \\
\hline China: Mainland ${ }^{d}$ & -0.2 & 2.6 & na \\
\hline Taiwan & 8.8 & 10.7 & 1.4 \\
\hline Hong Kong & 8.3 & 13.3 & 5.7 \\
\hline Indonesia & 18.1 & 21.4 & 10.3 \\
\hline Korea. South & 19.2 & 16.8 & 3.6 \\
\hline Malaysia & 7.1 & 5.6 & 0.2 \\
\hline Philippines $^{\mathrm{c}}$ & 13.0 & 12.5 & 17.9 \\
\hline Singapore & 5.2 & 6.9 & 0.1 \\
\hline Thailand & 8.1 & 9.8 & 2.5 \\
\hline \multicolumn{4}{|l|}{ Soulh Asia } \\
\hline Bangladesh & 23.0 & 12.3 & 10.1 \\
\hline India & 7.3 & 13.1 & 7.3 \\
\hline Nepal & 8.3 & 8.7 & 9.6 \\
\hline Pakistan & 15.5 & 9.0 & 6.0 \\
\hline Sri Lanka & 9.6 & 16.8 & 19.1 \\
\hline \multicolumn{4}{|l|}{ Pacific islands } \\
\hline Fiji & 13.2 & 8.4 & 5.6 \\
\hline Papua New Guinca & 7.8 & 6.3 & 6.4 \\
\hline Solomon Islands & 7.2 & 12.6 & 10.4 \\
\hline Tonga & 11.2 & 9.3 & 2.1 \\
\hline \multicolumn{4}{|l|}{ Developed countries } \\
\hline Australia & 10.3 & 10.1 & 7.2 \\
\hline Canada ${ }^{e}$ & 7.5 & 10.0 & 3.6 \\
\hline Japan" & 8.7 & 3.0 & 1.0 \\
\hline New Zealand & 13.0 & 14.4 & 10.0 \\
\hline United Statese & 6.9 & 8.5 & 3.3 \\
\hline
\end{tabular}

na $=$ nor available.

Noles:

a. Data not available for Brunei, Cambodia, Norıh Korea, Laos, Mongolia, Vieınam, Bhutan, Maldives, Cook Islands, Kiribati, New Caledonia, Vanuatu, and Western Samoa.

b. 1975-1978 for Solomon 1slands; 1974-1978 for Bangladesh and Pakistan; 1971-1978 for Malaysia.

c. 1983-1986 for Burma, Canada, Fiji, India, Malaysia, and Solomon Islands; 1983-1985 for Ausıralia, Indonesia, New Zealand, and Papua New Guinea; 1983-1984 for Sri Lanka; I983 for Tonga.

d. National income deflator.

c. GNP deflator.

Sources: Asian Development Bank, Key Indicutors of Developing Member Countries of ADB, Vol. XV (April 1984): Vol XVI (April 1985); Vol. XVII (July 1986); Vol. XVIIl (July 1987); Vol. XIX (July 1988). Hong Kong. Census and Statistics Department, Estimates of Gross Domestic Product 1966 10 1983. Hong Kong, Census and Statistics Department, Hong Kong Monthly Digest of Statistics, August 1988. International Monetary l'und, Imternational Financial Statistics, 1988 yearbook. Republic of China, Central Bank of China, Financial Statisics: Taiwan District, Republic of China, various monthly issues. Republic of China, Council for Economic Planning and Development. Taiwan Statistical Data Book, 1988. 
Table 5 Structure of GDP (percentage of GDP at current market prices)

\begin{tabular}{|c|c|c|c|c|c|c|c|c|c|c|c|c|}
\hline \multirow[b]{2}{*}{ Subregion/counlry } & \multicolumn{4}{|c|}{$1970^{\mathrm{a}}$} & \multicolumn{4}{|c|}{1978} & \multicolumn{4}{|c|}{$1987^{b}$} \\
\hline & $\begin{array}{l}\text { Agri- } \\
\text { culıure }\end{array}$ & $\begin{array}{l}\text { Manu- } \\
\text { fac- } \\
\text { turing }\end{array}$ & $\begin{array}{l}\text { Other } \\
\text { industry }\end{array}$ & Services & $\begin{array}{l}\text { Agri- } \\
\text { culture }\end{array}$ & $\begin{array}{l}\text { Manu- } \\
\text { fac- } \\
\text { turing }\end{array}$ & $\begin{array}{l}\text { Other } \\
\text { industry }\end{array}$ & Services & $\begin{array}{l}\text { Agri- } \\
\text { culture }\end{array}$ & $\begin{array}{l}\text { Manu- } \\
\text { fac- } \\
\text { curing }\end{array}$ & $\begin{array}{l}\text { Other } \\
\text { industry }\end{array}$ & Services \\
\hline \multicolumn{13}{|l|}{ Fast and Southeast Asia } \\
\hline Burma & 38 & 10 & 4 & 47 & 44 & 10 & 3 & 43 & 48 & 10 & 3 & 39 \\
\hline China: Mainland & па & na & na & na & 29 & 44 & 4 & 23 & 31 & \multicolumn{2}{|c|}{$-46-$} & 23 \\
\hline Taiwan & 16 & 34 & 8 & 43 & 10 & 42 & 10 & 39 & 5 & 44 & 9 & 43 \\
\hline Hong Kongd & 2 & 31 & 6 & 61 & I & 24 & 8 & 67 & 1 & 22 & 8 & 70 \\
\hline Indonesia & 47 & 9 & 9 & 35 & 30 & 11 & 25 & 35 & 26 & 14 & 18 & 42 \\
\hline Korea, South & 27 & 21 & 9 & 44 & 20 & 28 & 10 & 42 & 11 & 30 & 13 & 46 \\
\hline Malaysia ${ }^{\mathrm{e}}$ & 29 & 15 & 19 & 39 & 25 & 19 & 16 & 40 & 22 & $22^{\circ}$ & 16 & 40 \\
\hline Philippines & 28 & 23 & 7 & 43 & 27 & 25 & 10 & 39 & 25 & 25 & 8 & 43 \\
\hline Singapore & 2 & 20 & 10 & 68 & 2 & 26 & 8 & 64 & 1 & 29 & 9 & 62 \\
\hline Thailand & 28 & 16 & 9 & 46 & 27 & 19 & 9 & 45 & 17 & 21 & 9 & 53 \\
\hline \multicolumn{13}{|l|}{ South Asia } \\
\hline Bangladesh $^{\dagger}$ & 58 & 6 & 4 & 32 & 55 & 9 & 4 & 32 & 46 & 8 & 6 & 40 \\
\hline Bhuran & na & na & na & na & 40 & 2 & 3 & 55 & 51. & 4 & 12 & 34 \\
\hline India ${ }^{d}$ & 47 & 14 & 8 & 31 & 39 & 17 & 8 & 36 & 32 & 19 & 10 & 39 \\
\hline Maldives ${ }^{e}$ & na & na & na & กa & 37 & 4 & 11 & 48 & 21 & 20 & 17 & 43 \\
\hline Nepal $^{\mathrm{d}}$ & 68 & 9 & 2 & 21 & 63 & 4 & 8 & 25 & 62 & 5 & 7 & 25 \\
\hline Pakistand $^{d}$ & 36 & 16 & 6 & 42 & 32 & 15 & 8 & 46 & 24 & 18 & 11 & 48 \\
\hline Sri Lanka ${ }^{d}$ & 36 & 10 & 8 & 46 & 27 & 23 & 7 & 43 & 23 & 16 & 10 & 51 \\
\hline \multicolumn{13}{|l|}{ Pacific islands } \\
\hline Cook Islands & 26 & 11 & 11 & 51 & 17 & 5 & 5 & 73 & na & na & na & na \\
\hline Fijid.e & 27 & II & 9 & 53 & 23 & 12 & 8 & 57 & 24 & 12 & 8 & 56 \\
\hline Kiribati ${ }^{d}$ & 13 & 0 & 41 & 46 & 20 & 2 & 55 & 23 & 31 & 2 & 8 & 60 \\
\hline Papua New Guinea & 35 & 6 & 19 & 41 & 35 & 10 & 15 & 40 & 34 & 9 & 17 & 40 \\
\hline Tonga ${ }^{d}$ & 56 & 2 & 5 & 38 & 42 & 7 & 7 & 44 & 47 & 6 & 5 & 42 \\
\hline \multicolumn{13}{|l|}{ Developed countries } \\
\hline Australia & 6 & 24 & 15 & 55 & 6 & 19 & 16 & 59 & 5 & 17 & 17 & 62 \\
\hline Canada & 4 & 20 & 12 & 65 & 4 & 18 & 13 & 64 & 3 & na & 36 & 61 \\
\hline Japan & 6 & 36 & 11 & 47 & 5 & 30 & 12 & 54 & 3 & 30 & 11 & 56 \\
\hline New Zealand & 13 & 23 & 9 & 56 & 10 & 22 & 9 & 59 & 11 & na & 33 & 56 \\
\hline United States & 3 & 25 & 9 & 63 & 3 & 24 & 10 & 63 & 2 & 20 & II & 67 \\
\hline
\end{tabular}

Other industry = mining. construction, electricity, gas, and water.

Scrvices = Irade, Iransport and communications, finance, public administration and defense, and others. na $=$ not available.

Components may not add 10100 due to rounding errors and use of GDP at current market prices vs. current factor cost.

Noles:

a. 1971 for Malay'sia; 1972 for Kiribati; 1973 for Bangladesh and Pakistan.

b. 1983 for Maldives and Tonga; 1985 for Nepal; 1986 for Burma, China, Hong Kong, Indonesia, Thailand, India, Fiji, Papua New Guinea, Australia, Canada, Japan, New Zealand, and the United States.

c. Data not available for Brunei, Cambodia, North Korea, Laos, Mongolia, Vieınam, New Caledonia, Solomon Islands, Vanuatu, and Western Samoa.

d. Al current factor cost.

c. At constant prices.

f. Manufacturing and mining. Other industry = construction, electricity, gas, and water.

Sources: Asian Development Bank, Key Indicators of Developing Member Countries of ADB, Vol. XV (April 1984); Vol XV1 (April 1985); Vol. XVII (July 1986); Vol. XIX (July 1988). Organization for Economic Cooperation and Development, National Accounts Statistics, 1963-1980 (published 1982), 1972-1984 (published 1986). World Bank, World Development Report 1988. World Bank, World Tables, 4th ed. 
Table 6 Investment and Domestic Saving Ratios (investment and domestic savings as a percentage of GDP at current market prices)

\begin{tabular}{|c|c|c|c|c|c|c|}
\hline \multirow[b]{2}{*}{ Subregion/countryc } & \multicolumn{2}{|c|}{$1970^{\mathrm{a}}$} & \multicolumn{2}{|c|}{1978} & \multicolumn{2}{|c|}{$1987^{b}$} \\
\hline & Invesiment & $\begin{array}{l}\text { Domestic } \\
\text { savings }\end{array}$ & Invesiment & $\begin{array}{c}\text { Domestic } \\
\text { savings }\end{array}$ & Investment & $\begin{array}{c}\text { Domestic } \\
\text { savings }\end{array}$ \\
\hline \multicolumn{7}{|l|}{ East and Southeast Asia } \\
\hline Burma & 12 & 9 & 18 & 14 & 15 & 13 \\
\hline China: Mainland & na & na & 36 & 37 & 46 & 46 \\
\hline Taiwan & 26 & 26 & 29 & 35 & 20 & 39 \\
\hline Hong Kong & 21 & 25 & 30 & 26 & 26 & 32 \\
\hline Indonesia & 14 & 11 & 21 & 27 & 26 & 24 \\
\hline Korea, South & 25 & 15 & 31 & 28 & 29 & 30 \\
\hline Malaysia & 20 & 22 & 27 & 32 & 24 & 38 \\
\hline Philippines & 21 & 22 & 29 & 24 & 15 & 19 \\
\hline Singapore & 39 & 21 & 39 & 32 & 39 & 41 \\
\hline Thailand & 26 & 21 & 27 & 25 & 21 & 24 \\
\hline \multicolumn{7}{|l|}{ South Asia } \\
\hline Bangladesh & 9 & 10 & II & 3 & 11 & 3 \\
\hline India & 18 & 17 & 24 & 20 & 25 & 21 \\
\hline Maldives ${ }^{\mathrm{d}}$ & na & na & 15 & 19 & 24 & 4 \\
\hline Nepal & na & na & 18 & 8 & 21 & 11 \\
\hline Pakisıan & 13 & 14 & 18 & 9 & 17 & 11 \\
\hline Sri Lanka & 19 & 16 & 20 & 15 & 23 & 18 \\
\hline \multicolumn{7}{|l|}{ Pacific islands } \\
\hline Fiji & 22 & 21 & 23 & 18 & 17 & 18 \\
\hline Kiribali & 11 & 16 & 21 & 29 & na & na \\
\hline Papua New Guinca & 47 & 8 & 21 & 19 & 24 & 15 \\
\hline Tonga & 28 & -2 & 30 & -10 & 25 & -18 \\
\hline \multicolumn{7}{|l|}{ Developed countries } \\
\hline Australia & 27 & 27 & 25 & 22 & 24 & 24 \\
\hline Canada & 22 & 23 & 23 & 24 & 21 & 22 \\
\hline Japan & 39 & 40 & 31 & 33 & 28 & 32 \\
\hline New Zealand & 24 & 23 & 22 & 22 & 25 & 25 \\
\hline Uniled States & 18 & 18 & 21 & 20 & 18 & 15 \\
\hline
\end{tabular}

Domestic savings = GDP - private consumption - government consumption - statistical discrepancy. Investment = gross capital formation ( = fixed capital formation + changes in stocks).

na $=$ not available.

Notes:

a. 1972 for Kiribati; 1973 for Bangladesh and Pakistan; 1975 for Tonga.

b. 1983 for Maldives and Tonga; 1985 for Nepal and Fiji; 1986 for Burma, India, Indonesia, Japan, New Zealand, and Papua New Guinea.

c. Data not available for Brunei, Cambodia, North Korea, Mongolia, Vietnam, Bhutan, Cook Islands, New Caledonia, Solomon Islands, Vanuatu, and Western Samoa.

d. At 1985 constant market prices.

Sources: Asian Development Bank, Key Indicators of Developing Member Countries of ADB, Vol. XV (April 1984); Vol. XVI (April 1985); Vol. XVII (July 1986); Vol. XVIII (July 1987); Vol. XIX (July 1988). International Monetary Fund, International Financial Statistics, 1988 yearbook and November 1988 monthly. 
Table 7 Trade Shares of GDP (imports and exports as a percentage of GDP at current market prices)

\begin{tabular}{|c|c|c|c|c|c|c|}
\hline \multirow[b]{2}{*}{ Subregion/country ${ }^{c}$} & \multicolumn{2}{|c|}{$1970^{\mathrm{a}}$} & \multicolumn{2}{|c|}{1978} & \multicolumn{2}{|c|}{$1987^{b}$} \\
\hline & Imports & Exports & Imports & Exports & Imports & Exports \\
\hline \multicolumn{7}{|l|}{ East and Southeast Asia } \\
\hline Burma & 8 & 6 & 10 & 6 & 8 & 5 \\
\hline China: Mainland ${ }^{d}$ & 3 & 3 & 6 & 6 & 19 & 14 \\
\hline Taiwan & 30 & 30 & 46 & 52 & 42 & 61 \\
\hline Hong Kong & 89 & 93 & 88 & 85 & 117 & 123 \\
\hline Indonesia & 16 & 13 & 15 & 22 & 23 & 21 \\
\hline Korea, South & 24 & 14 & 33 & 30 & 36 & 45 \\
\hline Malaysia & 44 & 46 & 44 & 49 & 51 & 57 \\
\hline Philippines & 19 & 19 & 23 & 18 & 22 & 23 \\
\hline Singapore & 130 & 82 & 166 & 129 & 146 & 129 \\
\hline Thailand & 22 & 17 & 26 & 22 & 26 & 28 \\
\hline \multicolumn{7}{|l|}{ Soulh Asia } \\
\hline Bangladesh & 5 & 6 & 14 & 6 & 13 & 6 \\
\hline India & $: 5$ & 4 & 8 & 7 & 9 & 7 \\
\hline Maldives & na & na & na & na & 78 & 68 \\
\hline Pakistan & 14 & 15 & 19 & 9 & 19 & 13 \\
\hline Sri Lanka & 29 & 26 & 40 & 35 & 36 & 25 \\
\hline \multicolumn{7}{|l|}{ Pacific islands } \\
\hline Cook Islands & 71 & 32 & na & na & na & na \\
\hline Fiji & 52 & 48 & 47 & 43 & 44 & 44 \\
\hline Kiribali & 39 & 44 & 46 & 55 & 102 & 23 \\
\hline Papua New Guinea & s! & 19 & 44 & 41 & 54 & 45 \\
\hline \multicolumn{7}{|l|}{ Developed countries } \\
\hline Ausiralia & 15 & 15 & 16 & 14 & 18 & 16 \\
\hline Canada & 20 & 23 & 25 & 25 & 25 & 26 \\
\hline Japan & 10 & 11 & 10 & 12 & 13 & 13 \\
\hline New Zealand & 25 & 22 & 28 & 28 & 28 & 28 \\
\hline United States & 6 & 6 & 9 & 8 & 11 & 8 \\
\hline
\end{tabular}

Imports = imports of merchandise and nonfactor services as a percentage of GDP.

Exports = exports of merchandise and nonfactor services as a percentage of GDP.

$n a=$ nol available.

Notes:

a. 1973 for Bangladesh and Pakistan; 1972 for Kiribati.

b. 1983 for Kiribati; 1984 for India; 1985 for Fiji and Maldives; 1986 for Burma, China, Indonesia, Malaysia, Singapore, Papua New Guinea, Japan, and New Zealand.

c. Data not available for Brunei, Cambodia, North Korea, Mongolia, Vietnam, Bhutan, Nepal, New Caledonia, Solomon Islands, Tonga, Vanuatu, and Western Samoa.

d. Exports and imports as a percentage of national income.

Sources: Asian Development Bank, Key Indicalors of Developing Member Countries of ADB, Vol. XV (April 1984); Vol. XVI (April 1985); Vol. XVII (July 1986); Vol. XVIII (July 1987); Vol. XIX (July 1988). Hong Kong, Census and Statistics.Department, Estimates of Gross Domestic Product 1966 to 1983. Hong Kong, Census and Statistics Department, Hong Kong Momthly Digest of Statistics, October 1984 and August 1988. International Monetary Fund, Imternational Financial Statistics, 1988 yearbook. Republic of China..Council for Economic Planning and Development, Taiwan Statistical Dalu Book, 1988. 
Table 8 Merchandise Imports from Selected Asia-Pacific Trading Partners and Total Imports

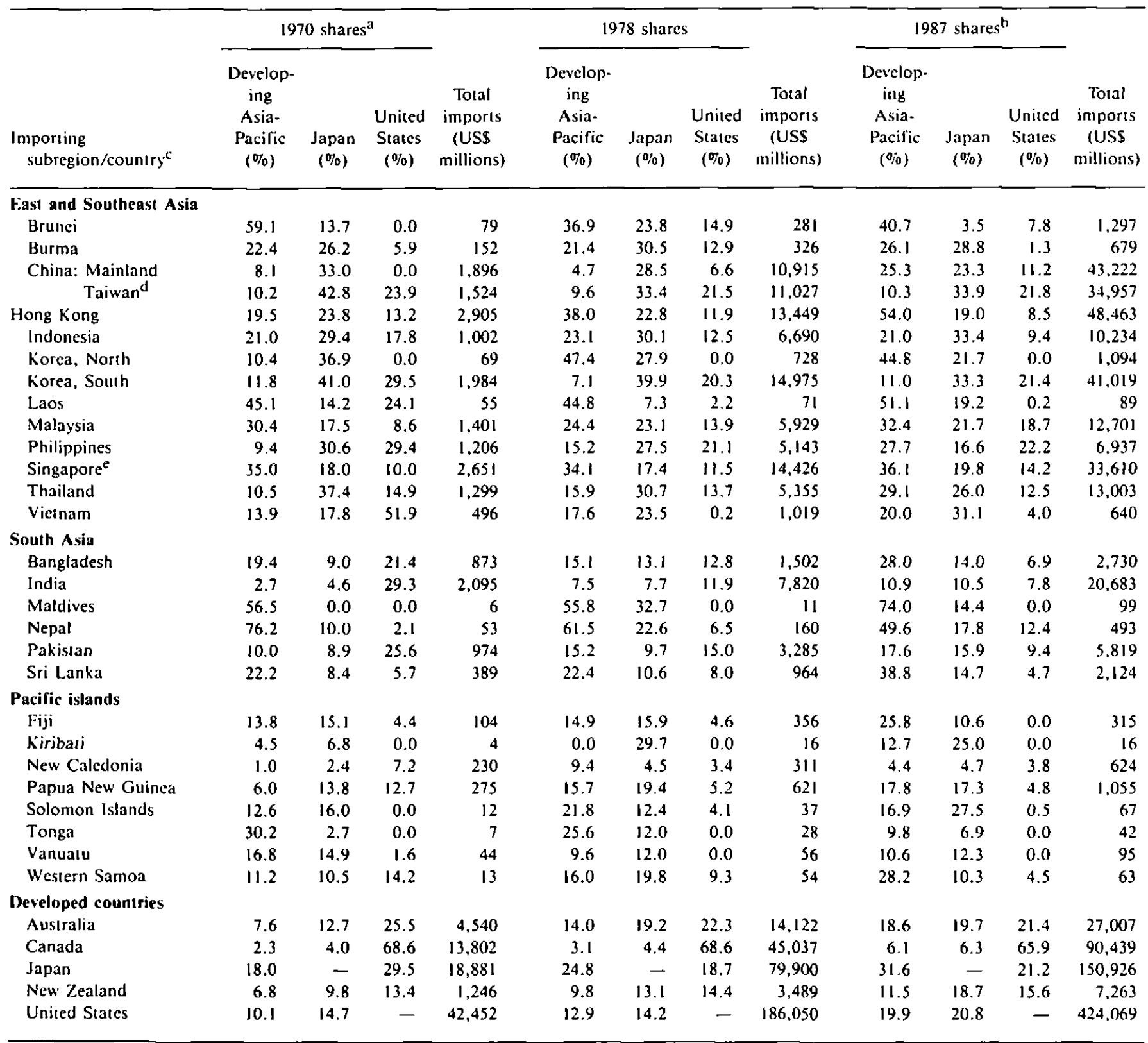

$-=$ not applicable.

Notes:

a. 1972 for Kiribati and Tonga: 1973 for Bangladesh. Pakistan, and Solomon Islands; 1974 for Maldives and Vanuatu.

b. 1985 for K'iribati.

c. Data not available for Cambodia, Mongolia, Bhutan, and Cook Islands. All countries' imports from China (Taiwan) are derived from Taiwan's f.o.b. export data. To account for freight and insurance costs, Taiwan's exports are multiplied by 1.1 to generate estimates of trading partner imports from Taiwan; however, such estimates could not be made for developing Asia-Pacific countries not listed in note d.

d. Data for developing Asia and Pacific cover only Hong Kong, India, Indonesia, South Korea, Malaysia, Philippines, Singapore. and Thailand.

c. Because Singapore does not record trade with Indonesia, Singapore's imports from Indonesia are derived from Indonesia's f.o.b. export data. To account for freight and insurance costs, Indonesia's exports are multiplied by 1.1 to obtain estimates of Singapore's imports from lndonesia.

Sources: Asian Development Bank, Key Indicators of Developing Member Countries of ADB, Vol. XV (April 1984); Vol. XVI (April 1985): Vol. XVII (July 1986); Vol. XVIII (July 1987); Vol. XIX (July 1988). International Monetary Fund, Direction of Trade Staristics, 1988 yearbook and 1988 computer data tapes. Republic of China, Ministry of Finance, Statistics Department, Monthly Statistics of Exports and Imports: The Republic of China (Taiwan District), No. 196 (December 1985) and No. 224 (April 1988). 
Table 9 Merchandise Exports to Selected Asia-Pacific Trading Partners and Total Exports

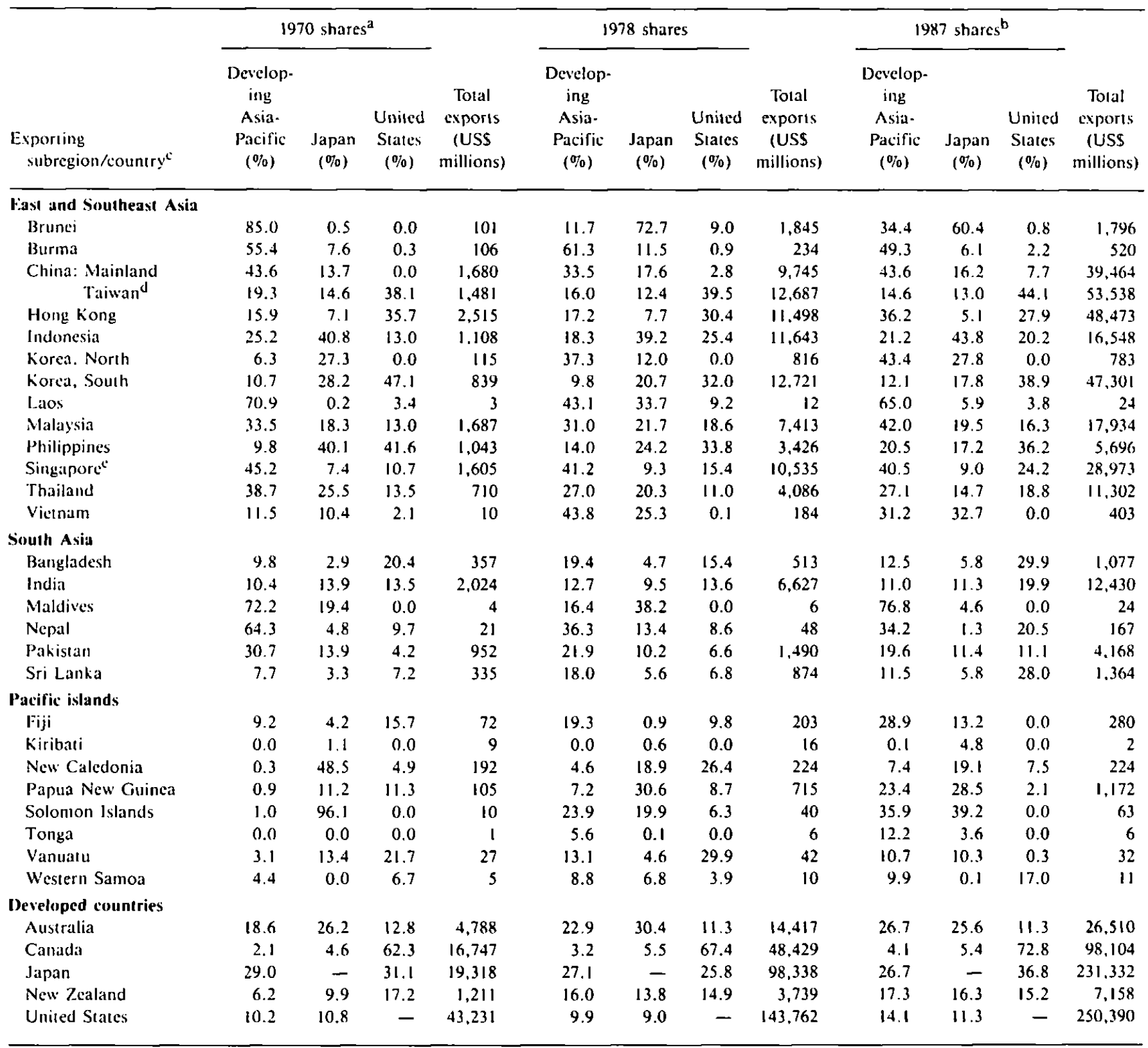

- = not applicable.

Notes:

a. 1971 for Tonga; 1972 for Kiribati; 1973 for Bangladesh, Pakistan, and Solomon Islands; 1974 for Maldives and Vanuatu.

b. 1985 for Kiribati.

c. Data not available for Cambodia, Mongolia, Bhutan, and Cook Islands. All countries' exports to China (Taiwan) are derived from Taiwan's c.i.f. export data. To account for freight and insurance costs, Taiwan's imports are divided by 1.1 to generate estimates of trading partner exports to Taiwan; however, such estimates could not be made for developing Asia-Pacific countries nor listed in note d.

d. Dala for developing Asia and Pacific cover only Hong Kong, India, Indonesia, South Korea, Malaysia, Philippines, Singapore, and Thailand.

e. Because Singapore does not record trade with Indonesia, Singapore's exports to Indonesia are derived from Indonesia's c.i.f. import data. To account for freight and insurance costs, Indonesia's imports are divided by 1.1 to obtain estimates of Singapore's exports to Indonesia.

Sources: Asian Development Bank, Key Indicators of Developing Member Countries of ADB, Vol. XV (April 1984); Vol. XVI (April 1985); Vol. XVII (July 1986); Vol. XVIII (July 1987); Vol. XIX (July 1988). Iniernational Monetary Fund, Direction of Trade Staristics, 1988 yearbook and 1988 computer data tapes. Republic of China, Ministry of Finance, Statistics Department, Monthly Statistics of Exports and lmports: The Republic of China (Taiwan District). No. 196 (December 1985) and No. 224 (April 1988). 
Table 10 Average Annual Capital Inflows by Type (US\$ millions)

\begin{tabular}{|c|c|c|c|c|c|c|c|c|c|c|c|c|c|c|c|}
\hline \multirow[b]{2}{*}{ Subregion/countryc } & \multicolumn{5}{|c|}{$1970-1978^{a}$} & \multicolumn{5}{|c|}{$1979-1982$} & \multicolumn{5}{|c|}{$1983-1987^{b}$} \\
\hline & $\begin{array}{c}\text { Toral } \\
\text { in llow }\end{array}$ & $\begin{array}{l}\text { Unre- } \\
\text { quited } \\
\text { trans- } \\
\text { fers }\end{array}$ & $\begin{array}{l}\text { Long- } \\
\text { term } \\
\text { capi- } \\
\text { tal }\end{array}$ & $\begin{array}{l}\text { Shorl- } \\
\text { term } \\
\text { capi- } \\
\text { tal }\end{array}$ & $\begin{array}{l}\text { Re- } \\
\text { serves. } \\
\text { errors }\end{array}$ & $\begin{array}{l}\text { Tolal } \\
\text { inflow }\end{array}$ & $\begin{array}{l}\text { Unre- } \\
\text { quiled } \\
\text { irans- } \\
\text { fers }\end{array}$ & $\begin{array}{l}\text { Long- } \\
\text { term } \\
\text { capi- } \\
\text { tal }\end{array}$ & $\begin{array}{l}\text { Short- } \\
\text { term } \\
\text { capi- } \\
\text { tal }\end{array}$ & $\begin{array}{c}\text { Re- } \\
\text { serves, } \\
\text { errors }\end{array}$ & $\begin{array}{l}\text { Total } \\
\text { inflow }\end{array}$ & $\begin{array}{l}\text { Unre- } \\
\text { quited } \\
\text { trans- } \\
\text { fers }\end{array}$ & $\begin{array}{l}\text { Long- } \\
\text { term } \\
\text { capi- } \\
\text { tal }\end{array}$ & $\begin{array}{c}\text { Shorl- } \\
\text { lerm } \\
\text { capi- } \\
\text { lal }\end{array}$ & $\begin{array}{c}\text { Re- } \\
\text { serves, } \\
\text { errors }\end{array}$ \\
\hline \multicolumn{16}{|l|}{ East and Southeast Asia } \\
\hline Burma & 90 & 18 & 49 & -1 & is & 452 & 72 & 359 & $s$ & 6 & 333 & 77 & 180 & 16 & 61 \\
\hline China: Mainland & na & na & na & na & na & na & na & na & na & na & 3,258 & 394 & 3.692 & -479 & -357 \\
\hline Taiwan & -260 & 6 & 265 & -341 & -196 & -645 & -136 & 1.212 & 460 & $-2,233$ & $-11,263$ & -291 & $-1,045$ & 3,201 & $-14,153$ \\
\hline Indonesia & 525 & 39 & 921 & -231 & -375 & 629 & 117 & 2,681 & -260 & -1.839 & 3,312 & 171 & 3.128 & 609 & -668 \\
\hline Korca, South & 1.068 & 244 & 1,048 & 303 & -513 & 4.664 & 472 & 2,623 & 2,379 & -863 & $-1,328$ & 794 & -789 & -376 & $-1,005$ \\
\hline Malaysia & -28 & -46 & 466 & -39 & -475 & 1.337 & -24 & 2.031 & -32 & -557 & 723 & 25 & 1,906 & -162 & -997 \\
\hline Philippines & 641 & 235 & 449 & 271 & -330 & 2,614 & 434 & 1.215 & 1.063 & -401 & 947 & $\$ 46$ & 1,254 & $-1,030$ & 117 \\
\hline Singapore & 555 & -26 & 287 & 280 & -123 & 1,141 & -125 & 1.456 & 308 & -476 & -225 & -208 & 728 & 25 & $-1,007$ \\
\hline Thailand & 519 & 83 & 305 & 250 & -138 & 2,089 & 157 & 1,635 & 272 & -48 & 1.779 & 210 & 988 & 278 & -11 \\
\hline \multicolumn{16}{|l|}{ South Asia } \\
\hline Bangladesh & 753 & 375 & 360 & -9 & 10 & 1.721 & 1,094 & 431 & 7 & 98 & 1.688 & 1,269 & 553 & -34 & -78 \\
\hline India & 468 & 873 & 452 & -17 & -977 & 4,564 & 2,825 & 728 & -161 & 1,100 & 6,066 & 2,787 & 3.035 & 58 & 40 \\
\hline Maldives & na & na & na & กа & na & 19 & 2 & 10 & 7 & 0 & 21 & 4 & 1 & 3 & 13 \\
\hline Nepal & па & na & na & ла & na & 153 & 115 & 48 & -3 & -3 & 245 & 124 & 89 & 4 & 16 \\
\hline Pakistan & 1.362 & 650 & 437 & 62 & 19 & 3.412 & 2,475 & 533 & 72 & 45 & 3.843 & 3.153 & 493 & -44 & -12 \\
\hline Sri Lanka & 80 & 43 & 69 & 3 & -23 & 668 & 312 & 316 & 32 & 68 & 627 & 367 & 290 & 6 & -40 \\
\hline \multicolumn{16}{|l|}{ Pacific islands } \\
\hline Fiji & 35 & 2 & 28 & 1 & 4 & 108 & 18 & 88 & 1 & 5 & 43 & 18 & 34 & -1 & -15 \\
\hline Papua New Guinea & 104 & 174 & 56 & -1 & -137 & 483 & 152 & 255 & 2 & 51 & 401 & 138 & 222 & 6 & 48 \\
\hline Solomon 1slands & na & na & na & กa & na & 24 & 15 & 6 & 1 & 3 & 18 & 12 & 7 & 2 & 3 \\
\hline Vanuatu & na & na & na & na & na & na & na & na & na & กa & 25 & 32 & 23 & -29 & -5 \\
\hline Western Samoa & 18 & 9 & 8 & -1 & 2 & 48 & 34 & $s$ & 3 & 4 & 35 & 39 & J & 0 & 2 \\
\hline \multicolumn{16}{|l|}{ Developed countries } \\
\hline Australia & 1,400 & -194 & 1,439 & 30 & 38 & 5,869 & -114 & 6,373 & 96 & -473 & 8,832 & 488 & 7,614 & -434 & 786 \\
\hline Canada & 2,310 & 538 & 2,388 & 671 & $-1,900$ & 2,893 & 897 & 1,526 & 2,920 & $-2,571$ & 3,431 & 939 & 4.435 & 1,051 & $-4,288$ \\
\hline Japan & -4.830 & -371 & $-3,752$ & 2,643 & -3.448 & 555 & $-1,413$ & -8.233 & 6,808 & 3,368 & $-57,644$ & $-2,092$ & -79.538 & 33,636 & $-9,694$ \\
\hline New Zealand & 578 & 4 & 149 & -21 & so & 1,171 & st & -285 & -47 & -247 & 1,441 & 112 & $-1,613$ & 119 & 387 \\
\hline United Stales & $-4,456$ & $-4,850$ & -10.251 & -6.967 & 1.319 & $-7,298$ & $-7,523$ & $-10,053$ & $-15,938$ & 23,648 & 99,380 & $-13,138$ & 42,422 & 34,466 & 15,728 \\
\hline
\end{tabular}

Total capital inflow $=-$ (current account balance) + (unrequited transfers).

Unrequited transfers $=$ (official transfers) + (private transfers).

Long-term capital $=($ direct investment $)+($ portfolio investment $)+($ other long-term capital $)$.

Short-term.capital $=$ other short-term capital flows.

Reserves, errors $=$ (net errors and omissions $)+$ (total change in reserves).

na $=$ nol available.

The sum of the components does not necessarily equal total inflows due to rounding errors and statistical discrepancies.

Notes:

a. 1972-1978 for Papua New Guinea; 1973-1978 for Bangladesh and Pakistan.

b. 1983-1985 for Burma, Maldives, and Solomon Istands; 1983-1986 for China, Thailand, India, and Fiji.

c. Data not available for Brunei, Hong Kong, Cambodia, North Korea, L.aos, Mongolia, Vietnam, Bhutan, Cook Islands, Kiribati, New Caledonia, and Tonga.

Sources: International Monetary Fund, International Financial Statistics, 1979 and 1988 yearbooks. Republic of China, Central Bank of China, Financial Statistics, Taiwan District, Republic of China, various monthly issues. 
Table 11 Average Annual Disbursements of Net Financial Inflows from OECD and OPEC Economies by Flow Type (US\$ millions)

\begin{tabular}{|c|c|c|c|c|c|c|c|c|c|c|c|c|}
\hline \multirow[b]{2}{*}{ Subregion/country ${ }^{b}$} & \multicolumn{4}{|c|}{$1970-1978^{a}$} & \multicolumn{4}{|c|}{$1979-1982$} & \multicolumn{4}{|c|}{$1983-1986$} \\
\hline & $\begin{array}{l}\text { Total } \\
\text { inflows }\end{array}$ & $\begin{array}{c}\text { Official } \\
\text { bi- } \\
\text { lateral }\end{array}$ & $\begin{array}{c}\text { Official } \\
\text { multi- } \\
\text { lateral }\end{array}$ & $\begin{array}{c}\text { Private } \\
\text { bi- } \\
\text { lateral }\end{array}$ & $\begin{array}{c}\text { Total } \\
\text { inflows }\end{array}$ & $\begin{array}{c}\text { Official } \\
\text { bi- } \\
\text { lateral }\end{array}$ & $\begin{array}{l}\text { Official } \\
\text { multi- } \\
\text { lateral }\end{array}$ & $\begin{array}{c}\text { Private } \\
\text { bi* } \\
\text { lateral }\end{array}$ & $\begin{array}{c}\text { Total } \\
\text { inflows }\end{array}$ & $\begin{array}{c}\text { Official } \\
\text { bi- } \\
\text { lateral }\end{array}$ & $\begin{array}{l}\text { Official } \\
\text { multi- } \\
\text { lateral }\end{array}$ & $\begin{array}{c}\text { Private } \\
\text { bi- } \\
\text { Jateral }\end{array}$ \\
\hline \multicolumn{13}{|l|}{ East and Southeast Asia } \\
\hline Burma & 96 & 57 & 26 & 13 & 417 & 227 & 93 & 96 & 348 & 232 & 106 & 11 \\
\hline Cambodia & 73 & 73 & 1 & -1 & 141 & 27 & 114 & 0 & 19 & 7 & 13 & 0 \\
\hline China: Mainland & na & na & па & na & 755 & 254 & 133 & 368 & 1,873 & 754 & 480 & 639 \\
\hline Taiwan & 189 & 70 & 25 & 94 & 495 & 239 & -20 & 275 & -281 & -168 & -18 & -94 \\
\hline Hong Kong & 251 & 47 & 2 & 202 & 1,229 & 16 & 15 & 1,198 & -107 & -2 & 1 & -106 \\
\hline Indonesia & 1,381 & 581 & 161 & 639 & 2,407 & 768 & 493 & 1,146 & 2,479 & 711 & 820 & 949 \\
\hline Korea, South & 923 & 371 & 206 & 346 & 1,360 & 417 & 431 & 513 & 1,330 & 121 & 253 & 956 \\
\hline Laos & 58 & si & 6 & 0 & 42 & 20 & 22 & 0 & 44 & 15 & 22 & 7 \\
\hline Malaysia & 214 & 65 & 55 & 94 & 808 & 115 & 123 & 570 & 863 & 295 & 55 & 513 \\
\hline Philippines & 510 & 177 & 93 & 241 & 1,079 & 260 & 395 & 424 & 1.061 & 636 & 384 & 40 \\
\hline Singapore & 180 & 35 & 21 & 124 & 895 & 42 & 1 & 852 & 304 & -35 & -12 & 351 \\
\hline Thailand & 220 & 89 & 75 & 56 & 1,215 & 373 & 371 & 472 & 1,045 & 422 & 401 & 222 \\
\hline Vietnam & 442 & 394 & 30 & 18 & 272 & 160 & 80 & 32 & 108 & 80 & 40 & -11 \\
\hline \multicolumn{13}{|l|}{ South Asia } \\
\hline Bangladesh & 724 & 505 & 214 & 5 & 1,252 & 871 & 374 & 6 & 1,226 & 715 & 504 & 7 \\
\hline India & 1,154 & 754 & 398 & 2 & 2,045 & 663 & 1,254 & 129 & 2,655 & 748 & 1,351 & 557 \\
\hline Nepal & 45 & 28 & 17 & 0 & 170 & 96 & 74 & 0 & 244 & 126 & 110 & 9 \\
\hline Pakistan & 752 & 611 & 151 & -10 & 992 & 504 & 376 & 112 & 799 & 343 & 493 & -37 \\
\hline Sri Lanka & 127 & 99 & 37 & -9 & 413 & 284 & 96 & 33 & 576 & 369 & 151 & 56 \\
\hline \multicolumn{13}{|l|}{ Pacific islands } \\
\hline Fiji & 27 & 16 & 5 & 6 & 76 & 44 & 22 & 10 & 42 & 25 & 18 & -1 \\
\hline Kiribati & 5 & 5 & 0 & 0 & 17 & 14 & 3 & 0 & 13 & 12 & 2 & 0 \\
\hline Papua New Guinea & 306 & 221 & 14 & 71 & 412 & 332 & 37 & 42 & 412 & 288 & 49 & 75 \\
\hline Vanuatu & 16 & 15 & 0 & $\mathbf{I}$ & 37 & 32 & 3 & 2 & 23 & 13 & 3 & 7 \\
\hline Western Samoa & 10 & 6 & 4 & 1 & 26 & 17 & 10 & 0 & 22 & 15 & 7 & 0 \\
\hline
\end{tabular}

Negatives indicate net outflows.

Components may not sum to totals due to rounding errors.

na $=$ not available.

Notes:

a. 1973-1978 for Bangladesh and Pakistan.

b. Data not available for Brunei, North Korea, Mongolia, Bhutan, Maldives, Cook Islands, New Caledonia, Solomon Islands, and Tonga.

Sources: Organization for Economic Cooperation and Development, Geographical Distribution of Financial Flows to Developing Countries, various issues and computer tapes. 
Table 12 Communications Media in the Region

\begin{tabular}{|c|c|c|c|c|}
\hline Country & $\begin{array}{c}\text { Telephones }^{\mathrm{a}} \\
\text { per } 100 \\
(1985)\end{array}$ & $\begin{array}{c}\text { Daily' } \\
\text { newspaper } \\
\text { circulationb } \\
\text { per } 1,000 \\
(1984)\end{array}$ & $\begin{array}{c}\text { Television } \\
\text { receivers } \\
\text { per } 1,000 \\
(1985)^{\mathrm{c}}\end{array}$ & $\begin{array}{c}\text { Radio } \\
\text { reccivers } \\
\text { per } 1,000 \\
(1985)\end{array}$ \\
\hline Australia & 55.0 & 296 & 446 & 1.274 \\
\hline Bangladesh & $0.1^{\mathrm{e}}$ & 6 & 3 & 40 \\
\hline Burna & $0.1^{f}$ & 74 & I & 81 \\
\hline Cambodia & na & na & 7 & 110 \\
\hline China: Mainland & 0.6 & 29 & 9 & 113 \\
\hline Taiwan & $27.7 \mathrm{~g}$ & па & na & na \\
\hline Hong Kong & 42.4 & na & 236 & 586 \\
\hline India & $0.5^{h}$ & $21^{\mathrm{e}}$ & 5 & 66 \\
\hline Indonesia & $0.3^{i}$ & 18 & 39 & 117 \\
\hline Japan & $55.5^{\mathrm{h}}$ & 562 & 580 & 787 \\
\hline Korca, South & 18.6 & กа & 187 & 937 \\
\hline Malaysia & 8.1 & 323 & 101 & 424 \\
\hline New Zealand & $64.5^{h}$ & $325^{\mathrm{e}}$ & $290 j$ & 904 \\
\hline Pakisian & 0.6 & na & 13 & 90 \\
\hline Philippines & 1.5 & na & 28 & 65 \\
\hline Singapore & $41.7^{\mathrm{h}}$ & 277 & $195 \mathrm{j}$ & $281^{j}$ \\
\hline Sri Lanka & $0.7^{f}$ & $111^{e}$ & 28 & 155 \\
\hline Thailand & 1.5 & na & 97 & 175 \\
\hline
\end{tabular}

na $=$ not available.

Notes:

a. As of December 31, except as noted. Public and private telephones installed that can be connected to a central exchange.

b. Publications containing general news and appearing at least four times a week; may range in size from a single sheet 1050 or more pages. Circulation data refer 10 average circulation per issue or number of printed copies per issue and include copies sold outside the country.

c. Estimated number of sets in use, except as noted.

d. Data cover estimated number of receivers in use, except as noted, and apply to all types of receivers for radio broadcasts to the public, including receivers connected to a radio "redistribution system" but excluding television sets.

c. For 1982 .

f. For 1983.

g. For 1984.

h. As of March 31.

i. For 1980.

j. Number of licenses issued.

Source: U.S. Department of Commerce, Burcau of the Census, Statistical Abstract of the United States 1988, 108ih ed. 
APPENDIX TABLES

Table 13 Asia-Pacific Defense Statistics

\begin{tabular}{|c|c|c|c|c|}
\hline \multirow[b]{2}{*}{ Country } & \multicolumn{3}{|c|}{ Defense expenditure: 1987} & \multirow{2}{*}{$\begin{array}{l}\text { Number in } \\
\text { the armed } \\
\text { forces: } 1987 \\
\text { (thousands) }\end{array}$} \\
\hline & $\begin{array}{l}\text { USS } \\
\text { millions }\end{array}$ & $\begin{array}{c}\text { USS } \\
\text { per capita }\end{array}$ & $\begin{array}{c}\% \\
\text { GNP/GDPa }\end{array}$ & \\
\hline Afghanisıan & na & na & na & 50.0 \\
\hline Ausiralia & 5,265 & 316 & 2.7 & 70.5 \\
\hline Bangladesh ${ }^{\mathrm{a}}$ & 217 & 2 & 1.3 & 101.5 \\
\hline Bruneia & 232 & 977 & 7.2 & 4.1 \\
\hline Burma & 292 & 7 & 3.1 & 186.0 \\
\hline China: Mainland & 5,636 & 5 & 2.6 & $3,200.0$ \\
\hline Taiwan & 5,068 & 245 & 5.8 & 424.0 \\
\hline $\mathrm{Fiji}$ & 14 & 19 & 1.1 & 2.6 \\
\hline India & 9,648 & 12 & 3.5 & $1,262.0$ \\
\hline Indonesia & 1,320 & 8 & 2.4 & 284.0 \\
\hline Japan & 25,422 & 207 & 1.0 & 246.0 \\
\hline Korea, North & 4,223 & 195 & na & 838.0 \\
\hline Korea, South & 5,735 & 134 & 5.2 & 629.0 \\
\hline Laos & na & กа & na & 55.5 \\
\hline Malaysia & 853 & 51 & 3.7 & 113.0 \\
\hline Mongolia & 249 & 124 & na & 33.5 \\
\hline Nepal & 37 & 2 & 1.3 & 30.0 \\
\hline New Zcaland & 807 & 241 & 2.0 & 12.6 \\
\hline Pakistan & 2,543 & 25 & 6.5 & 480.6 \\
\hline Papua New Guincaa & 34 & 10 & 1.4 & 3.5 \\
\hline Philipnines & 725 & 13 & 1.7 & 105.0 \\
\hline Singapore & 1,222 & 463 & 6.6 & 55.5 \\
\hline Sri Lanka & 611 & 37 & 8.9 & 22.0 \\
\hline Thailand & 1,740 & 32 & 3.7 & 256.0 \\
\hline Victnam & na & na & na & $1,252.0$ \\
\hline
\end{tabular}

na = not available.

Note:

a. For 1986

Source: International Institute for Strategic Studies, The Military Balance 1988-1989, pp. 169, 181, 226, London: The International Instiute for Strategic Studies, 1988. 


\section{East-West Center Administration}

Victor $\mathrm{HaO} \mathrm{Li}$

President

Lee-Jay Cho

Vice President for Academic Affairs and Director, Population Institute

Seiji Naya

Vice President for Strategic Planning and

Director, Resource Systems Institute

Wesley T. Park

Vice President for Administration. and Corporate Treasurer

Nancy T. Taylor

Corporate Secretary

Robert B. Hewelt

Interim Director, Institute of Culture and Communication

Norton S. Ginsburg

Director, Environment and Policy Instituse

Charles lepani

Direcior, Pacific lslands Development Program

Sarah D. Miyahira

Dean. Student Affairs and Open Grants

Webster K. Nolan

Director, Public Affairs

\section{East-West Center Board of Governors}

\author{
George Chaplin \\ EWC Chairman of the Board \\ Editor-at-Large \\ The Honolulu Advertiser \\ Honolulu, Hawaii
}

R. Daniel McMichael

EWC Vice Chairman of the Board

Administrative Agent

Scaife Family Charitable Trusts

Pittsburgh, Pennsylvania

Kenneth F. Brown

Business Execulive

Honolulu, Hawaii

John Franklin Copper

Sianley J. Buckman Professor of International Studies

Rhodes College

Memphis, Tennessee

Frank J. Hala

Presidenı

Diversified Distributor, Inc.

Honolulu, Hawaii

Keiji Kawakami

President

lolani Sporiswear, Lid.

Honolulu, Hawaii

Hon. Duck-Woo Nam

Chairman

Korea Foreign Trade Association

Seoul, Korea

Robert C. Oshiro

Altorney-at-Law

Wahiawa, Hawaii

Gopalaswami Parthasarathi

Chairman

Indian Institute of Mass

Communication

New Delhi, India
Hon. James B. Pearson

Of Counsel

LeBoeuf. Lamb, Leiby \& MacRae

Washingron, D.C.

Jan Ching-An Ting

Professor of Law

Temple University School of Law

Philadelphia, Pennsylvania

Amnuay Viravan

Chairman of the Executive Board

Bangkok Bank Limited

Bangkok; Thailand

Laurence Vogel

President

Duty Free Shoppers Group Limited

Honolulu, Hawaii

Jusuf. Wanandi

Executive Director

Centre for Strategic and International Srudies

Jakarla, Indonesia

lsamu Yamashita

Chairman

East Japan Railway Co., Lid., and

Senior Advisor

Mitsui Engineering and Shipbuilding Co., LId.

Tokyo, Japan

\section{Ex-Officio Members}

Hon. John. Waihee

Governor

Srate of Hawaii

Mark N. Blitz.

Associale Director

U.S. Information Agency

Washingron, D.C.

Albert J. Simone

President

Universify of Hawaii

Honolulu, Hawaii 


\section{The east-west Center}

is a public, nonprofit educational institution with an international board of governors. Some 2,000 research fellows, graduate students, and professionals in business and government each year work with the Center's international staff in cooperative study, training, and research. They examine major issues related to population, resources and development, the environment, culture, and communication in Asia, the Pacific, and the United States.

The Center was established in 1960 by the United States Congress, which provides principal funding. Support âlso comes from more than 20 Asian and Pacific governments, as well as private agencies and corporations.

Asia-Pacific Report 1989

Focus: China in the Reform Era

US\$15:00

Asia-Pacific Report 1987-88

Trends, Issues, Challenges

US\$10.00

A review of economic and political events in the mid-1980s. Plus special sections on critical marine issues arising from technological advancements and a new law of the sea, and the challenges facing the developing Pacific island nations. Includes statistical tables, charts, and maps.

Asia-Pacific Report 1986

Trends, Issues, Challenges

US\$10.00

A review of the past quarter-century and a baseline against which to evaluate regional changes. Assesses political and economic events, demographic trends, renewable resources: use, and the minerals and fuels future. Includes statistical tables, charts, and maps:

To order, send an international money order or draft on a U.S. bank to: Distribution Office, East-West Center," 1777 East-West Road, Honolulu, Hawaii 96848. Prices include surface postage. Please specify which volume(s) is being ordered. As a special offer, all three volumes are available as:a set for $\cdot$ US\$25. 